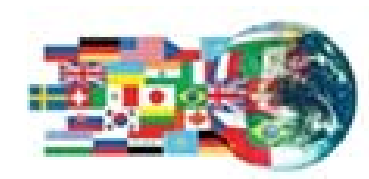

$\frac{\text { Pacific Northwest Center for }}{\text { Global Security }}$

\title{
Technical and Political Assessment of Peaceful Nuclear Power Program Prospects in North Africa and the Middle East
}

\author{
September 2007 \\ Lindsay Windsor \\ Carol Kessler \\ Pacific Northwest Center for Global Security
}

Pacific Northwest

National Laboratory

Operated by Battelle for the

U.S. Department of Energy 


\title{
Disclaimer
}

This report was prepared as an account of work sponsored by an agency of the United States Government. Neither the United States Government nor any agency thereof, nor Battelle Memorial Institute, nor any of their employees, makes any warranty, express or implied, or assumes any legal liability or responsibility for the accuracy, completeness, or usefulness of any information, apparatus, product, or process disclosed, or represents that its use would not infringe privately owned rights. Reference herein to any specific commercial product, process, or service by trade name, trademark, manufacturer, or otherwise does not necessarily constitute or imply its endorsement, recommendation, or favoring by the United States Government or any agency thereof, or Battelle Memorial Institute. The views and opinions of authors expressed herein do not necessarily state or reflect those of the United States Government or any agency thereof.

\author{
PACIFIC NORTHWEST NATIONAL LABORATORY \\ operated by \\ BATTELLE \\ for the \\ UNITED STATES DEPARTMENT OF ENERGY \\ under Contract DE-AC05-76RL01830
}




\section{$\underline{\text { TABLE OF CONTENTS }}$}

Country Reports

Page 3 
Page 4 


\section{EXECUTIVE SUMMARY}

An exceptional number of Middle Eastern and North African nations have recently expressed interest in developing nuclear energy for peaceful purposes. Many of these countries have explored nuclear research in limited ways in the past, but the current focused interest and application of resources towards developing nuclear-generated electricity and nuclear-powered desalination plants is unprecedented. Consequently, questions arise in response to this emerging trend: What instigated this interest? To what end(s) will a nuclear program be applied? Do these countries have adequate technical, political, legislative, nonproliferation, and safety infrastructure required for the capability they desire? If so, what are the next steps for a country if it wishes to prepare for a future nuclear program? Is there something the United States can or should contribute? And if a country does not have the infrastructure needed, what collaboration efforts are possible with the United States or others? This report provides information on the capabilities and interests of 13 countries in the region in light of their interest in nuclear energy programs with regard to safety, nonproliferation and physical security. It also provides information useful for determining the potential for U.S. offers of technical collaboration, financial aid, and/or political support.

Some speculate that the emerging nuclear interest in these countries is a response to Iran's nuclear capability. David Sanger of The New York Times reports that Iran's potential nuclear program threatens neighboring nations to a greater degree than Israel's nuclear capability, for reasons related to the tentative balance of power among religious groups in the region. Sanger's analysis is worth quoting at length:

"For years there have been warnings of a nuclear arms race in the Middle East, and it's never come to pass. Israel got its bomb in the late 1960's and many believed that Arab nations would respond with a weapon of their own; although some countries, like Egypt, expressed strong interest in a nuclear weapon.

"But Iran, in many ways, is more threatening to many of these countries, according to both the diplomats we've interviewed and outside experts. The reason is simple: Iran is a Shi'a country sitting in the midst of Sunni Arab states. Iran is, in their minds, a more unpredictable regime, and one that has aspirations to become a power throughout the Middle East. It's particularly worrisome to Saudi Arabia, because a nuclear-armed Iran could challenge Saudi dominance in the region."

In February 2006, Saudi Foreign Minister Saud al-Faisal expressed his country's security concerns which have emerged as a result of Iran's nuclear development. He criticized Iran's uranium enrichment program, asking, "Where is Iran going to use these weapons? If their intention is to bomb Israel, they will kill Palestinians, Syrians, Jordanians, and Saudis, as well." " Yet few of the moderate Arab leaders in the region

\footnotetext{
${ }^{1}$ Sanger, David. “Sunni Nuclear Concerns,” David E. Sanger Reports, New York Times. April 2007. http://www.nytimes.com/pages/world/middleeast/index.html

${ }^{2}$ Salama, Sammy and Heidi Weber. "The Emerging Arab Response to Iran's Unabated Nuclear Program", Nuclear Threat Initiative, 22 December 2006. Accessed 4 May 2007.

http://www.nti.org/e_research/e3_83.html
} 
have expressed an interest in blocking Iran and other states from obtaining this technology. Several have begun to explore nuclear energy programs as well. These leaders have domestic incentives to develop nuclear technologies, as Arab constituencies have been vocal about all states having an undeniable right to acquire nuclear technology. Nuclear power capability is also perceived to convey regional leadership, showing that a country has modernized and developed to a degree others seek to achieve.

Unlike Iran, most of the moderate Arab nations have been applying for nuclear development projects in conjunction with the IAEA, and openly which provides some reassurance of their peaceful intent. Yet, a dilemma remains because some aspects of developing a nuclear power program and/or some technical research program can provide a country with knowledge, technology and/or material useful for a nuclear weapons program also. Security concerns also increase over any nuclear program pursuit in a region that tends to be less than stable politically such as the Middle East. Iraq, Iran and Libya appear to examples that prove this point, though Libya did finally agree to dismantle its weapons of mass destruction program. The Treaty on the Nonproliferation of Nuclear Weapons (NPT) encourages the five nuclear weapons states to aid any country seeking to develop nuclear power for peaceful purposes. However, there appears to be a view now among many developed nuclear countries that not all technologies need to be shared with all states. The sensitive nuclear technologies - enrichment and reprocessing - are of greatest concern and are not needed domestically to run a nuclear power program because if needed these services can be bought more economically from existing technology holders. There are now proposals to restrict the spread of these technologies made by the United States and several other countries.

Based on the following analyses, it appears many of these Middle Eastern and North African countries could benefit from a nuclear energy and/or nuclear desalination program in terms of the economics, and consequent national growth and development, as well as for protecting the environment. Jordan, for example, has little to no domestic energy resources, and has indicated that a source of electricity which is not based on imported fuel would improve its national security, provide for greater energy independence, and generate jobs and a skilled workforce to help improve its poor economy. None of these countries have sufficient water resources, and many are already using conventional desalination plants to provide water for their residents. These plants require significant amounts of energy, which is now generated primarily from oil and natural gas. Yet, the countries aim to decrease carbon emissions and increase the percentage of fossil fuels available for export revenue, so some see nuclear desalination as a good alternative. Regional projects would also allow for the pooling of resources where funds, raw materials, technology, and expertise can be limited. For example, uranium resources of Morocco could be used for a nuclear desalination plant in Egypt and a portion of the water then transported to Libya. Some collaboration has already been initiated by the Gulf Cooperation Council, which seeks to develop a feasibility study on a joint nuclear desalination program within the year. Further collaborative efforts are possible among all these nations.

This report consists of a technical, political, and economic survey for each of thirteen countries in the Middle East and North Africa. It assesses each country's current 
nuclear capability, as well as energy and water resources (see Appendix R), stated nuclear intentions, international participation in the IAEA and other safety and security agreements, and projections for collaboration on a nuclear program with neighboring nations. Some of these factors are summarized in Table 1 below. The report indicates that Egypt and Turkey have the most advanced nuclear infrastructure, but Algeria, Libya and Morocco are not far behind with research reactors, university level nuclear educational programs and an existing cadre of nuclear scientists. These countries are the most likely candidates for an expanded nuclear program in the near term or for leadership in a joint nuclear power project. The United Arab Emirates, Oman, Kuwait, Qatar and Yemen have the least nuclear infrastructure or existing capability. It would take them considerable time to develop sufficient national infrastructure to support a nuclear program of any size. Tunisia and Saudi Arabia have expressed some interest in nuclear development, especially for desalination and have university level education, potential uranium resources in large phosphate deposits and some nuclear scientific expertise, but are less likely to be capable of developing a nuclear program in the short term.

As nuclear energy becomes safer, less expensive, more widely used, and thus a more viable option for power generation, some Middle East and North African nations could be expected to claim that they need the benefits from developing a nuclear program for meeting national economic and energy security goals. Providing effective guidance and international oversight (safeguards) as they examine this option will be an important challenge for the international community to address in the coming century. 


\begin{tabular}{|c|c|c|c|c|c|c|c|c|c|}
\hline Country & $\begin{array}{c}\text { Research } \\
\text { Reactor }\end{array}$ & Desalination & $\begin{array}{l}\text { University } \\
\text { Programs }\end{array}$ & $\begin{array}{l}\text { Professional } \\
\text { Scientists }\end{array}$ & $\begin{array}{c}\text { IAEA } \\
\text { Member }\end{array}$ & $\begin{array}{c}\text { IAEA } \\
\text { Safeguards } \\
\text { in Effect }\end{array}$ & $\begin{array}{c}\text { Additional } \\
\text { Protocol in } \\
\text { Effect }\end{array}$ & $\begin{array}{c}\text { NPT } \\
\text { Signatory }\end{array}$ & $\begin{array}{l}\text { Domestic } \\
\text { Uranium } \\
\text { Reserves }\end{array}$ \\
\hline Egypt & $x$ & $x$ & $x$ & $x$ & $x$ & $x$ & & $x$ & \\
\hline Jordan & & $x$ & & & $x$ & $x$ & $x$ & $x$ & $x$ \\
\hline Turkey & $x$ & $x$ & $x$ & $x$ & $x$ & $x$ & $x$ & $x$ & $x$ \\
\hline Morocco & $x$ & $x$ & $x$ & $x$ & $x$ & & $x$ & $x$ & $x^{*}$ \\
\hline Libya & $x$ & $x$ & $x$ & $x$ & $x$ & $x$ & $x$ & $x$ & \\
\hline Saudi Arabia & & $x$ & $x$ & $x$ & $x$ & & & $x$ & $x^{*}$ \\
\hline Algeria & $x$ & $x$ & $x$ & $x$ & $x$ & $x$ & & $x$ & $x^{*}$ \\
\hline Tunisia & & $x$ & $x$ & $x$ & $x$ & $x$ & & $x$ & $x^{\star}$ \\
\hline UAE & & $x$ & & & $x$ & $x$ & & $x$ & \\
\hline Kuwait & & $x$ & & & $x$ & $x$ & $x$ & $x$ & \\
\hline Oman & & $x$ & & & & $x$ & & $x$ & \\
\hline Qatar & & $x$ & & & $x$ & & & $x$ & \\
\hline Yemen & & $x$ & & & $x$ & $x$ & & $x$ & \\
\hline
\end{tabular}

The Desalination axis indicates whether the country has a need for desalination facilities and has indicated that nuclear powered desalination facilities are a national focus.

$>$ The University Programs axis indicates whether the country's universities have graduate programs in nuclear energy.

$>$ The Professional Scientist axis indicates whether a country has a substantial existing base of educated nuclear scientists with experience in nuclear energy.

$>$ The Domestic Uranium Reserves axis indicates whether the country specified has notable conventional uranium reserves.

* Morocco, Saudi Arabia, and Tunisia do not have any domestic conventional uranium reserves, but they do have substantial deposits of phosphates and these countries have the technological capacity to extract uranium from phosphates. In addition, Algeria has both phosphate reserves and moderate domestic uranium reserves. 


\section{EGYPT}

Overview

Egypt is a rapidly growing nation with high population increase, rising energy needs, limited natural resources, and aims of increasing GDP growth rates and a stronger leadership role in the Middle East. By population, Egypt ranks $16^{\text {th }}$ in the world with about 79 million people. Egypt's nominal GDP per capita ranks $144^{\text {th }}$ in the world at about $\$ 4,200$ (compare to a world average of $\$ 10,000$ ). Military expenditures account for about $3.4 \%$ of Egypt's GDP, ranking $44^{\text {th }}$ in the world in this respect. Egypt is $29^{\text {th }}$ in land area, though most of its land is arid and unsuitable for farming. Compared to a world average energy use per capita of about $3,000 \mathrm{kWh}$, and especially U.S. use of $12,400 \mathrm{kWh}$, Egypt's energy use is quite low, at just over 1,000 kWh. ${ }^{3}$ (CIA Factbook 2007)

In terms of nuclear technology, Egypt is likely the most highly developed among Arab states. It has a well-built nuclear infrastructure with two research reactors and regulatory mechanisms for the planning and control of nuclear development, though it lacks any proven exploitable uranium resources. Due to significantly increasing domestic demand for electricity, as well as prospects for nuclear powered water desalination, Egypt has strong interest in developing a nuclear power program. Its current energy industry relies mainly on oil and gas, with some wind power. Egypt could increase aspects of efficiency and transmission in electricity; but decreased oil production, decreased reserves, and increased oil consumption provide incentive for research into other possible energy resources. Egypt is a member of the IAEA and has signed and ratified the Nuclear Nonproliferation Treaty (NPT), but it lacks some of the legal structural framework needed for nuclear safety and security. Though there are recent concerns regarding nondisclosure of bench-scale nuclear experiments, as well as covert exchange of nuclear technology, Egypt has been a leader in the Middle East effort to establish a Weapons of Mass Destruction Free Zone. Egypt appears to be relatively low-risk for developing a domestic nuclear weapons program. The country has established involvement in other international agreements and protocols, and is involved in many domestic, regional, and interregional Technical Cooperation projects. Egypt's technical and infrastructural accomplishments could allow it to become a regional base for nuclear energy programs, particularly for training and technology sharing, among Arab states in the Middle East and North Africa.

\section{NUCLEAR INFRASTRUCTURE/INTENTIONS}

\section{Infrastructure}

Knowledge management

Egypt has a labor force of 21.8 million people, of whom $17 \%$ work in industry. A large part of the economy is devoted to services, particularly tourism, and Egypt's literacy rate (defined as age 15 and over who can read and write) is $71.4 \%$ but split by

\footnotetext{
${ }^{3}$ Central Intelligence Agency. "Egypt," The World Factbook. Last updated 15 March 2007. Accessed 5 April 2007. https://www.cia.gov/library/publications/the-world-factbook/geos/eg.html
} 
gender $83 \%$ of males and $59.4 \%$ of females. ${ }^{4}$ Egypt has several university programs related to nuclear energy. Ain Shams University in Cairo, for example, offers postgraduate courses in nuclear physics and power reactor physics. The University of Alexandria offers degrees in applied and nuclear physics, and Assuit University has a mining department and laboratories offering training in nuclear-related analysis. The American University in Cairo's Physics Department houses an Advanced Nuclear Laboratory, which is part of an overall program to offer theoretical and applied physics courses, with specific courses on nuclear physics. The Department of Physics at Tanta University conducts research in theoretical physics, solid state physics, nuclear radiation physics, lasers physics, plasma physics, nuclear physics, electronics, bio-physics and solar energy physics. This department also conducts joint research with institutes throughout Europe, Japan, the United States, and other Middle Eastern countries. At Mansoura University, the Nuclear Physics and Environmental Radioactivity Measurements Research Group focuses on nuclear physics and environmental radioactivity studies. Cairo University's Mechanical Power Engineering Department offers related courses including nuclear power plant operations and nuclear physics. ${ }^{5}$ Among Helwan University's professors there are experts in nuclear chemistry. ${ }^{6}$

Egypt's Atomic Energy Agency (AEA) states that, "More than 850 highly qualified academic scientists in various fields of nuclear science and engineering, supported by about 650 technical staff," work on R\&D projects of nuclear research. Founded in 1997, the Egyptian Nuclear Physics Association publishes a periodical called the Journal of Nuclear and Radiation Physics and organizes nuclear physics-related conferences and events. ${ }^{8}$

\section{Uranium Resources}

Egypt does not report any "known" uranium resources according to the standard IAEA classification system. ${ }^{9}$ However, there are "speculative" resources of about 100 tons of uranium. Since exploration began in the 1950's, uranium occurrences have been found in sandstone deposits in the Bahariya Oasis, the Eastern and Western Deserts, and areas of the Sinai Peninsula, which could indicate the possible presence of conventional uranium resources. The El Atshan Deposit in the Eastern Desert held the first major occurrence of uranium ore materials discovered. Two tons of uranium ore from this deposit, averaging $0.077 \%$ uranium, were extracted and analyzed at the Inchas Semi-Pilot

\footnotetext{
${ }^{4}$ Central Intelligence Agency. "Egypt," The World Factbook. Last updated 15 March, 2007. Accessed 5 April, 2007. https://www.cia.gov/library/publications/the-world-factbook/geos/eg.html

${ }^{5}$ Center for Nonproliferation Studies, Monterey Institute of International Studies. "Egypt Profile: Nuclear Facilities, Research and Development." Nuclear Threat Initiative, 2003. Accessed April 5, 2007. http://www.nti.org/e_research/profiles/Egypt/Nuclear/1695_1747.html

${ }^{6}$ Douara, Deena. "The Past, Present, and Future of Nuclear Power in Egypt," The Daily Star Egypt, 12 November 2006. Accessed 6 April 2007. http://www.dailystaregypt.com/article.aspx?ArticleID=3902

7 Atomic Energy Authority. "About AEA". Accessed 5April, 2007. http://www.frcu.eun.eg/www/homepage/aea/about.htm

${ }^{8}$ Egyptian Nuclear Physics Association, http://www.geocities.com/physicsegypt/Enpa.html

${ }^{9}$ Joint Report by the OECD Nuclear Energy Agency and the International Atomic Energy Agency.

Uranium 2005:Resources, Production, and Demand, Paris: OECD Publishing, 2005. p. 156-8
} 
Fuel Laboratory. ${ }^{10}$ Exploration for conventional uranium resources is conducted in the Eastern Desert under a Technical Cooperation project with the IAEA (TC project EGY/03/014). ${ }^{11}$

These explorations thus far have found mainly secondary sources of uranium. Phosphate deposits have been found in areas of the Western Desert, the Nile Valley, and the Red Sea coast, and the IAEA estimates the uranium content of all phosphate deposits to be 33,000 tons, which because of the high price of uranium may be recoverable. Egypt's Nuclear Materials Authority has conducted bench-scale projects in order to assess uranium recovery from unconventional secondary resources such as phosphates and black sands. ${ }^{12}$

\section{Nuclear Reactors and Fuel Facilities}

The Egyptian AEA was established in 1955 with a mandate to enable the country to efficiently utilize peaceful applications of nuclear energy. ${ }^{13}$ The AEA is divided into four research centers: The Nuclear Research Center (NRC) and the Hot Laboratories and Waste Management Centre (HLWMC), both located in Inshas, $60 \mathrm{~km}$ from Cairo; and the National Centre for Radiation Research and Technology (NCRRT) and the National Centre for Nuclear Safety and Radiation Control (NCNSRC), both located in Nasr City, which is east of Cairo.

The NRC houses some major science and research facilities, such as the light water ETRR-1 Research Reactor, a Van De Graff accelerator, a Low Active Solid Waste Incinerator, and the Semi-Pilot Heavy Water Laboratory. ETRR-1 is a research reactor with a maximum thermal power of $2 \mathrm{MW}$. Its construction was completed in March 1958 and its date of criticality was 8 February 1961. The reactor is used 3 hours per day, 3 days per week, and 20 weeks per year. Nine horizontal channels are used for neutron physics, solid state, and shielding research; eight vertical channels are used for production of radioisotopes. Fuel for this reactor originated from and was enriched by Russia.

The HLWMC works on radioisotope production in addition to waste treatment and management. The NCRRT is used for research in ionizing radiation for medical, industrial, agricultural, and environmental applications. Major research and service facilities include the Mega Gamma Irradiation Unit and the Electron Accelerator (under construction). The NCNSRC is responsible for regulations and safety issues related to the nuclear installations, and personnel and environmental protection from radiation.

Egypt also has an open pool reactor in Inchas at the Reactor Engineering Centre, ETRR-2. This Multi-Purpose Reactor (MPR), a cylindrical pool with a $4.5 \mathrm{~m}$ diameter built in stainless steel, produces $22 \mathrm{MW}$ of steady thermal power with a maximum thermal neutron flux of $2.7 \times 10^{14} \mathrm{n} / \mathrm{cm}^{2}$-s. It has several beam tubes, hot cells, high

\footnotetext{
${ }^{2}$ Center for Nonproliferation Studies, Monterey Institute of International Studies. "Egypt Profile: Nuclear Facilities, Milling and Mining." Nuclear Threat Initiative, 2003. Accessed April 5, 2007. http://www.nti.org/e_research/profiles/Egypt/Nuclear/1695_1745.html

${ }^{11}$ Joint Report by the OECD Nuclear Energy Agency and the International Atomic Energy Agency. Uranium: 1993 Resources, Production, and Demand, Paris: OECD Publishing, 1994. p. 133.

${ }^{12}$ Joint Report by the OECD Nuclear Energy Agency and the International Atomic Energy Agency. Uranium: 1993 Resources, Production, and Demand, Paris: OECD Publishing, 1994. p. 133.

${ }^{13}$ Atomic Energy Authority. "About AEA". Accessed 5 April, 2007. http://www.frcu.eun.eg/www/homepage/aea/about.htm
} 
pressure test loops and other research equipment. Fuel elements are low enriched uranium $\left(19.75 \%\right.$ enriched $\left.\mathrm{U}_{3} \mathrm{O}_{8}\right)$ with aluminum cladding. The reactor is moderated by light water. An auxiliary pool for fuel storage and radioactive materials handling adjoins the reactor. The facility is in operation 24 hours per day, 7 days per week, and 42 weeks per year. The MPR's stated intent is to be "used for research in neutron physics, materials science, nuclear fuel $\mathrm{R} \& \mathrm{D}$, radioisotope production, neutron radiography, activation analysis, boron neutron capture therapy and training in nuclear engineering and reactor operation." Fissile material for the reactor originated in Russia. ${ }^{14}$

Egypt has two fuel fabrication facilities. A Semi-Pilot Fuel Laboratory at the $\mathrm{NRC}$ is a laboratory-scale $\mathrm{UO}_{2}$ fuel fabrication facility. Constructed by the AEA with assistance and equipment from Germany, the laboratory became fully operational in 1990, and it is owned and operated by the Department of Metallurgy of the AEA. This facility is an experimental pressurized, heavy-water fuel fabrication facility with a design capacity of 0.1 tons heavy metal per year. ${ }^{18}$

A Fuel Manufacturing Pilot Plant (FMPP) at the same site was designed to produce up to 40 fuel elements per year. The FMPP supplies Egypt's MPR (ETRR-2), and its capacity is sufficient for the continuous operation of the reactor. The plant was designed and constructed by INVAP of Argentina and became operational in May 1998. $^{19}$

\section{Regulation}

Several nuclear authorities are responsible for nuclear technology, research, and management in Egypt. They include the Ministry of Electricity and Energy, the Ministry of Higher Education, the Atomic Energy Authority, Nuclear Materials Authority (NMA), Hot Laboratory and Waste Management Centre, Nuclear Power Plants Authority (NPPA), the Ministry of Health and Population (MOHP), the Ministry of Trade and Industry, and the Agriculture Department for Soil and Water Research.

Egypt's Ministry of Higher Education directs the vision of scientific research in the country and manages relations within and among universities. The AEA is responsible for the operation of nuclear reactors and fuel facilities. Egypt established the NPPA in 1976 in order to negotiate the purchase of two power reactors from the United

\footnotetext{
${ }^{14}$ INFCIS, "Nuclear Fuel Cycle Information System, List of Nuclear Fuel Cycle Facilities: Egypt." International Atomic Energy Association, 2003. Accessed 5 April 2007. http://www-nfcis.iaea.org/Default.asp

15 Research Reactor Database. "Nuclear Research Reactors in the World: Egypt." International Atomic Energy Agency, 1999. Accessed 5 April 2007. http://www.iaea.org/worldatom/rrdb/

${ }^{16}$ Center for Nonproliferation Studies, Monterey Institute of International Studies. "Egypt Profile: Nuclear Facilities, Fuel Fabrication.” Nuclear Threat Initiative, 2003. Accessed 5 April 2007. http://www.nti.org/e_research/profiles/Egypt/Nuclear/1695_1746.html

${ }^{17}$ Report by the Director General. Implementation of the NPT Safeguards Agreement in the Arab Republic of Egypt. International Atomic Energy Agency, September 2005. Accessed 5 April 2007. http://www.carnegieendowment.org/static/npp/Egypt_Feb_2005.pdf

18 INFCIS, "Nuclear Fuel Cycle Information System, List of Nuclear Fuel Cycle Facilities: Egypt." International Atomic Energy Association, 2003. Accessed 5 April 2007.

http://www-nfcis.iaea.org/Default.asp

${ }^{19}$ Center for Nonproliferation Studies, Monterey Institute of International Studies. "Egypt Profile: Nuclear Facilities, Fuel Fabrication." Nuclear Threat Initiative, 2003. Accessed 5 April 2007. http://www.nti.org/e_research/profiles/Egypt/Nuclear/1695_1746.html
} 
States and the subsequent operation of the reactors. ${ }^{20}$ The NMA is responsible for studies to assess and to manage the radioactive wastes produced from mining and milling, as well as to monitor radiation controls of imported and local raw materials. ${ }^{21}$ MOHP has regulatory control over all radioactive sealed sources in the public sector, which includes irradiation facilities, research facilities, several industrial sites, and a large number of hospitals and clinics. ${ }^{22}$

\section{Intentions}

The government of Egypt has had plans since the 1980's for nuclear power plants for electricity generation and water desalination. In late September 2006, Egypt's Energy Minister, Hassan Younes, announced that the country intended to resume a nuclear power program it froze 20 years ago following the Chernobyl accident. The first nuclear power station would be constructed at El-Dabaa, along Egypt's northern coast, within a decade. This 1,000 MW power plant has a projected cost of $\$ 1.5$ billion, for which the government is seeking foreign investment. ${ }^{23}$

The IAEA's Department of Nuclear Energy describes Egypt's nuclear power intentions in this way:

"The reasons which led the country to promote launching a nuclear power program were basically the following:

1. Steadily increasing demand for energy and electricity, caused by population growth, urbanization, industrialization, and the desire and intention to improve the conditions and the standard of living of the people;

2. Inadequate and insufficient known national primary energy resources to supply on a medium and long term the increasing demand for energy and electricity; as well as limited potable water resources, which will require the utilization of energy intensive desalination technology particularly in remote areas.

3. Perception of nuclear power as a convenient, economically competitive and viable source of energy which, if introduced in the country, would not only complement the traditional energy sources, but would also promote technological development and serve as an incentive for social and economic progress.

These reasons have not only retained their validity, but have been reinforced by the developments which have been taking place. Currently, energy and electricity

\footnotetext{
${ }^{20}$ Center for Nonproliferation Studies, Monterey Institute of International Studies. "Egypt Profile: Nuclear Chronology, 1970's." Nuclear Threat Initiative, August 2005. Accessed 17 April 2007. http://www.nti.org/e_research/profiles/Egypt/Nuclear/1697_1740.html

${ }^{21}$ Joint Report by the OECD Nuclear Energy Agency and the International Atomic Energy Agency. Uranium 2005:Resources, Production, and Demand, Paris: OECD Publishing, 2005. p. 158

${ }^{22}$ Ellis, Dori. "International Radiological Threat Reduction in Egypt," International Security News, Vol. 6, No. 1. Sandia National Laboratory, June 2006. Accessed 16 April 2007. http://www.cmc.sandia.gov/isn/June2006.pdf

${ }^{23}$ BBC News, "Egypt Unveils Nuclear Power Plan”. 25 September 2006. http://news.bbc.co.uk/2/hi/middle_east/5376860.stm
} 
demand continues to grow faster than population, and it is recognized that no economic development can be achieved without satisfying this demand."24

Egypt's energy demand does seem to be increasing rapidly. The country's projected population growth is $1.75 \%$ (2006 est.), and according to the CIA World Factbook, this rapid growth in population is overstraining natural resources. ${ }^{25}$ The electricity demand growth rate has averaged about $7 \%$ per year, and the country faces worsening shortages. ${ }^{26,27}$

Figure 1, using data from Egypt's Ministry of Electricity and Energy, shows the growth of energy consumption by various sectors of the economy since 1990.

Figure 1. Energy Consumption Growth by Purpose of Use, 1990-2004. ${ }^{28}$

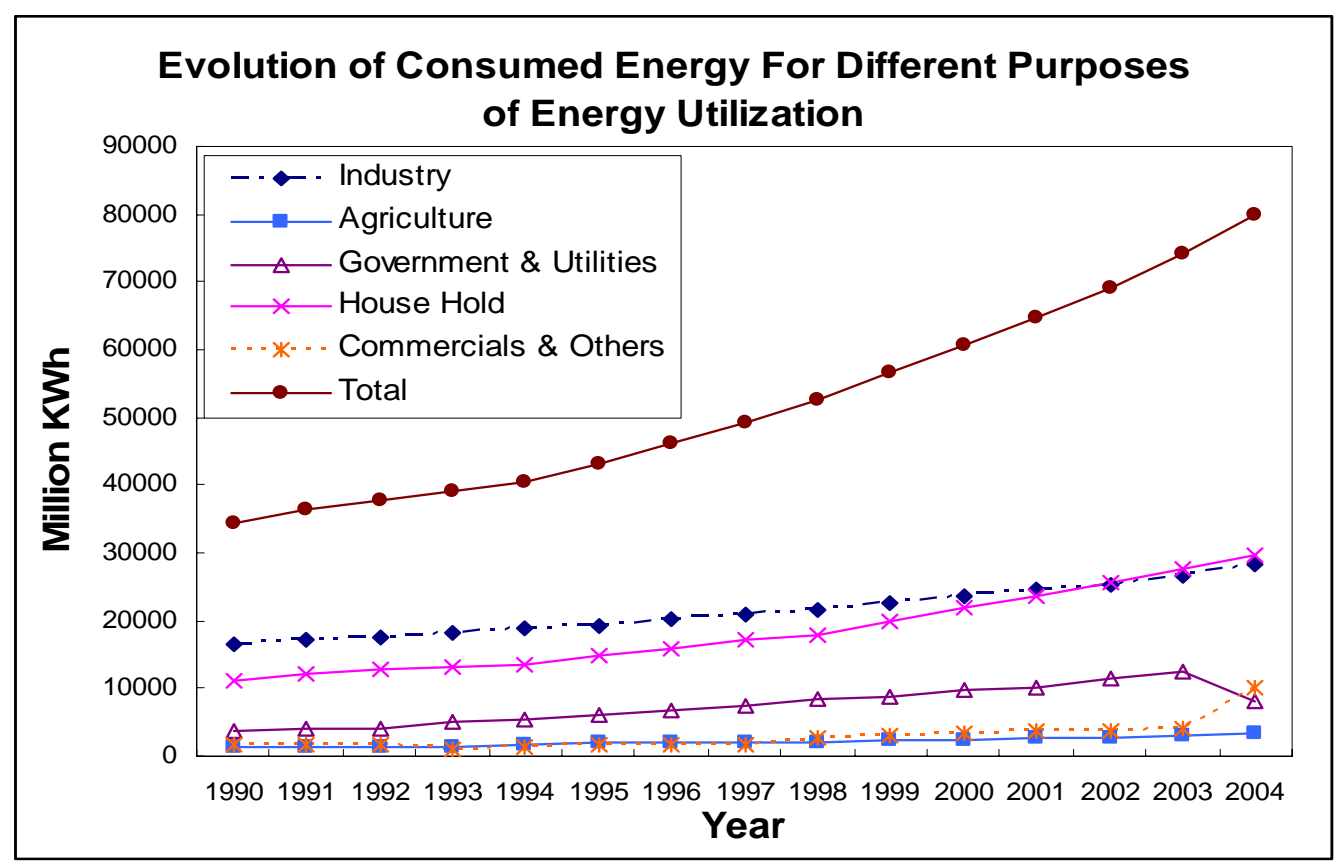

Total energy consumption is rapidly increasing, particularly by private households. Based on an extrapolation from this data, Egypt's energy consumption could increase by $50 \%$ from 2004 to 2010 alone.

\footnotetext{
${ }^{24}$ IAEA Department of Nuclear Energy, "Country Nuclear Power Profiles: Egypt”, last updated August 2005. Accessed 5 April 2007. http://www-

pub.iaea.org/MTCD/publications/PDF/cnpp2004/CNPP_Webpage/countryprofiles/Egypt/Egypt2005.htm

${ }^{25}$ Central Intelligence Agency. "Egypt," The World Factbook. Last updated 15 March, 2007. Accessed 5 April, 2007. https://www.cia.gov/library/publications/the-world-factbook/geos/eg.html

${ }^{26}$ BBC News, "Egypt Unveils Nuclear Power Plan”. 25 September 2006.

http://news.bbc.co.uk/2/hi/middle_east/5376860.stm

27 Javendanfar, Meir. "Egypt-Opportunities." The Middle East Economic and Political Analysis Company. Accessed 5 April 2007. http://www.meepas.com/egyptopportunitiespart1.htm

${ }^{28}$ Ministry of Electricity and Energy, "Technical Statistics: Evolution of Consumed Energy for Different

Purposes of Utilization.” Accessed 5 April 2007. http://www.moee.gov.eg/english/e-fr-main.htm.
} 
Currently, Egypt conducts Technical Cooperation projects (explained in more detail below) related to the environmental problems of increasing soil salination, desertification, and limited natural fresh water resources away from the Nile; the production of fresh water through water desalinization in particular would be aided by nuclear energy (See Appendix Q). Egypt has already launched a feasibility study of a cogeneration plant for electricity and potable water at El-Dabaa, on the Mediterranean coast. $^{29}$

Egypt may also have domestic and regional policy motivations for accruing the prestige of nuclear power. The ISN Security Watch, Swiss based security think tank, cites, for example, the correlation of the ruling party's nuclear announcement with the rising power of the Muslim Brotherhood, possibly in an effort to maintain their political clout despite the Brotherhood's increased influence. Nuclear power also provides a focal point for national pride in technological achievements, despite domestic issues of widespread poverty, corruption, and a high unemployment rate. Egypt is already the most advanced in terms of nuclear technology among Arab states in the Middle East, and the country's continued development in this respect helps to maintain its desired role as regional leader. Significantly, a nuclear energy program in Egypt could also provide "a salient symbol of national sovereignty vis-à-vis the US and European nations," by increasing political and economic independence and asserting Egypt's strength and capability. ${ }^{30}$

Nevertheless, Egypt's nondisclosure to the IAEA of certain nuclear materials, activities, and collaborations has led to concerns about their nuclear intentions. Libya and Egypt covertly exchanged nuclear and missile technology in late $2003 .^{31}$ In early 2005, a report from the IAEA Director General stated that Egypt had possessed undeclared material and conducted undeclared activities at their nuclear facilities which could potentially be used in weapons programs. The materials and activities related to uranium extraction and conversion, the irradiation of uranium targets, and reprocessing. ${ }^{32}$ Prior to 1982, Egypt failed to report " $67 \mathrm{~kg}$ of imported $\mathrm{UF}_{4}, 3 \mathrm{~kg}$ of uranium metal (some of which had been imported, and some of which had been produced from imported $\mathrm{UF}_{4}$ ), approximately $9.5 \mathrm{~kg}$ of imported thorium compounds, and small amounts of domestically produced $\mathrm{UO}_{2}, \mathrm{UO}_{3}$ and $\mathrm{UF}_{4},{ }^{, 33}$ but these materials were small-scale and not directly geared toward nuclear weapons fabrication. Other experiments were planned and conducted, but not reported, on the

\footnotetext{
${ }^{29}$ Uranium Information Centre, Ltd. "Nuclear Desalination," UIC Nuclear Issues Briefing Paper \# 74. October 2006. Accessed 5 April 2007. http://www.uic.com.au/nip74.htm

${ }^{30}$ Moran, Dominic. “Inside Egypt's Nuclear Debate," ISN Security Watch. 26 March 2007. Accessed 5 April 2007. http://www.isn.ethz.ch/news/sw/details.cfm?ID=17413

31 "Report: Libya, Egypt Swapped Nukes," United Press International, March 31 2004, cited in Center for Nonproliferation Studies, Monterey Institute of International Studies. "Egypt Profile: Nuclear

Chronology." Nuclear Threat Initiative, 2004. Accessed April 5, 2007.

http://www.nti.org/e_research/profiles/Egypt/Nuclear/1697_4612.html

${ }^{32}$ Bowen, Wyn Q. and Joanna Kidd. "The Nuclear Capabilities and Ambitions of Iran's Neighbors", Getting Ready for a Nuclear-Ready Iran. Henri Sokolski and Patrick Clawson, ed. Strategic Studies Institute, October 2005. Accessed 5 April 2007. p. 51-88.

http://www.strategicstudiesinstitute.army.mil/pdffiles/pub629.pdf

${ }^{33}$ Report by the Director General. Implementation of the NPT Safeguards Agreement in the Arab Republic of Egypt. Gov/2005/9. International Atomic Energy Agency, September 2005. Accessed 5 April 2007. http://www.carnegieendowment.org/static/npp/Egypt_Feb_2005.pdf
} 
separation of plutonium and uranium from irradiated fuel elements of the $2 \mathrm{MW}$ research reactor, but Egypt claims that no plutonium or enriched uranium was separated during these experiments, and explained that the laboratories had not been declared to the Agency because they had been intended only to be used for radioisotope production. Indeed, the quantities of natural uranium were quite small: $1.15 \mathrm{~g}$ of natural uranium compounds were used at the $2 \mathrm{MW}$ research reactor between 1990 and 2003, and a total of $0.24 \mathrm{~g}$ of natural uranium compounds were irradiated in four experiments at the 22.5 MW reactor between 1999 and 2000. Egypt's safeguards agreement, which is modeled on the standard INFCIRC/153 language, includes the exemption allowed in INFCIRC/153 of up to 10 metric tons of natural uranium and 20 metric tons of thorium from safeguards ${ }^{34}$ so it is possible that Egypt was not actually required to report its nuclear material. At any rate, the activities were not clandestine: though not reported to the IAEA, the nuclear research was published in open literature. The materials may have also been on the reactor's "List of Inventory Items," which is open to IAEA inspectors. The IAEA Director General's 2005 report concludes,

"The repeated failures by Egypt to report nuclear material and facilities to the Agency in a timely manner are a matter of concern. Egypt has explained that its past failure to report was attributable to a lack of clarity about its obligations under its Safeguards Agreement, particularly as regards small quantities of nuclear material used in research and development activities. Egypt has indicated that it will report any such material and activities in the future." 35

Though such evidence does establish cause for concern, the Federation of American Scientists asserts that, "Egypt has not engaged in significant efforts to develop a nuclear weapons capability," since spent fuel waste from the reactors has not been in quantities large enough to produce any meaningful amount of weapons-grade material necessary for a nuclear weapon. Rather, they have focused "serious work on developing nuclear potential designated for use in power engineering, agriculture, medicine, biotechnology, and genetics.",36

Indeed, in the past few decades, Egypt has been a strong proponent and leader in the effort to establish a Weapons of Mass Destruction Free Zone in the Middle East. Though in 1995 Egypt attempted to delay the permanent extension of the NPT, it did so based on fears that despite its compliance with the treaty's provisions, Egypt's accession to the Treaty did not provide it with sufficient security in light of the continuing nuclear

\footnotetext{
${ }^{34}$ International Atomic Energy Agency. "The Text of the Agreement Between Egypt and the Agency for the Application of Safeguards in Connection with the Treaty on the Non-Proliferation of Nuclear Weapons.” INFCIRC/302. July 1983. Accessed 9 April 2007. http://www.iaea.org/Publications/Documents/Infcircs/Others/infcirc302.pdf

${ }^{35}$ Report by the Director General. Implementation of the NPT Safeguards Agreement in the Arab Republic of Egypt. Gov/2005/9. International Atomic Energy Agency, September 2005. Accessed 5 April 2007. http://www.carnegieendowment.org/static/npp/Egypt_Feb_2005.pdf

${ }^{36}$ Pike, John. "Egypt: Nuclear Weapons Program.” Federation of American Scientists, 4 February 2005. Accessed 5 April 5, 2007. http://www.fas.org/nuke/guide/egypt/nuke/index.html
} 
threat from Israel. ${ }^{37}$ Egypt's approval of the Treaty extension was pending the confirmation of a "Resolution on the Middle East," the only region-specific resolution passed by the Review and Extension Conference that year. This Resolution contained strong language directed at Israel's ambiguous nuclear policy, underlining the Arab states' concern over Israel's repeated refusal to accede to the NPT. The Resolution:

"Notes with concern the continued existence in the Middle East of unsafeguarded nuclear facilities, and reaffirms in this connection the recommendation contained in section VI, paragraph 3, of the report of Main Committee III urging those non-parties to the Treaty on the Non-Proliferation of Nuclear Weapons that operate unsafeguarded nuclear facilities to accept fullscope International Atomic Energy Agency safeguards; [and]

"Reaffirms the importance of the early realization of universal adherence to the Treaty, and calls upon all States of the Middle East that have not yet done so, without exception, to accede to the Treaty as soon as possible and to place their nuclear facilities under full-scope International Atomic Energy Agency safeguards." 38

The Resolution continues by calling for the "establishment of an effectively verifiable Middle East zone free of weapons of mass destruction, nuclear, chemical and biological, and their delivery systems," and the Arab states' willingness to include this clause, which strongly affects their own defense systems, should not go unnoticed.

The 1991 Madrid Peace Conference, for which Egypt assumed a leadership role, established a multinational mechanism to work on making the Middle East a nuclear weapon-free zone. This mechanism, however, stalled in 1995 as a result of the Israeli position. In April 1996, Egypt hosted the conference for signing the declaration on rendering Africa a nuclear-weapons free zone. ${ }^{39}$ More recently, in February 2006, the Egyptian government achieved a symbolic victory in implementing its goal of a Weapons of Mass Destruction Free Zone in the Middle East. At Egyptian insistence, a paragraph calling for a WMD-free zone in the Middle East was included in the IAEA resolution of 4 February 2006, which was prepared to report Iran to the United Nations Security Council. $^{40}$

Thus, despite any small-scale research conducted by the Egyptians on reprocessing or the irradiation of uranium, Egypt seems to lack the motivation to develop a full-scale domestic nuclear weapons program. Any concern related to Egypt as a nuclear power may be more profitably directed at import and export controls, as US

\footnotetext{
${ }^{37}$ Preparatory Committee for the 2000 Review Conference of the Parties to the Treaty on the NonProliferation of Nuclear Weapons, "The 1995 Resolution on the Middle East." 5 May 1998. Accessed 5 April 2007. http://www.reachingcriticalwill.org/legal/npt/NPTDocuments/NPT_CONF.2000_PC.II_23.htm 38 "Resolution on the Middle East," Nonproliferation Treaty. Accessed 5 April 2007. http://disarmament2.un.org/wmd/npt/1995RESME.htm

${ }^{39}$ Pike, John. "Egypt: Nuclear Weapons Program." Federation of American Scientists, 4 February 2005. Accessed 5 April 5, 2007. http://www.fas.org/nuke/guide/egypt/nuke/index.html

${ }^{40}$ Center for Nonproliferation Studies, Monterey Institute of International Studies. "Egypt Profile: Nuclear Overview." Nuclear Threat Initiative, November 2006. Accessed April 5, 2007. http://www.nti.org/e_research/profiles/Egypt/Nuclear/index_1692.html
} 
intelligence reports have shown Egyptian collaboration with North Korea and Russia on missile and other defense systems. In 1996, US intelligence detected at least seven shipments from North Korea of materials for Scud-C missiles, which has the capacity to carry a conventional high-explosive, a 5 to 80 kiloton nuclear weapon, or a chemical warhead. A year later, the CIA confirmed that Egypt obtained spare parts and technology from North Korea and Russia for the similar Scud-B missiles, and Egypt continued to do so at least through February 1999. ${ }^{41}$ The US State Department sanctioned three Egyptian industrial companies in 1999 for engaging in missile proliferation activities with North Korea, though in the same month, "the United States agreed to sell Egypt a \$3 billion arms package that includes a Patriot air-defense missile system, 24 advanced F-16D fighter jets, and $200 \mathrm{M} 1 \mathrm{Abrams}$ tanks. This deal followed an earlier agreement in which Egypt acquired from the United States more than 10,000 rounds of armor piercing depleted uranium ammunition for its M1A1 tanks." 42 Since then, Lockheed Martin established a contract with Egypt to upgrade their air defense radar systems for tactical ballistic missile defense. In February 2000, news media alleged that Western nuclear technology was being transmitted through Egyptian government-owned companies to North Korea, where it was adapted and returned as advanced missile components. (Wisconsin Project 2000)

Yet Egypt has taken steps to minimize risk of smuggling nuclear materials through its borders. In June 2006, Egypt signed a Declaration of Principles with the National Nuclear Security Administration (NNSA) and U.S. Customs and Border Protection (CBP) to help detect and deter illicit trafficking of nuclear and other radioactive material. This agreement initiates the implementation of the NNSA's Megaports Initiative and the CBP's Container Security Initiative in Egypt. Egypt is one of four Middle Eastern countries to have joined the Initiative; the others are Dubai, Israel, and Oman. $^{43}$

\section{ECONOMIC}

\section{Electricity}

Egypt annually produces 91.72 billion $\mathrm{kWh}$ of electricity (as of 2004) and consumes 84.49 billion $\mathrm{kWh}$ of electricity. $81 \%$ of the energy produced is from fossil fuels; $19 \%$ is from hydropower from the Aswan Dam. Some wind power is also generated by wind power units near the Suez Canal. Egypt imports 200 million kWh and exports 1 billion kWh. Currently Egypt does not produce electricity from nuclear power. (CIA Factbook 2007)

\footnotetext{
${ }^{41}$ Central Intelligence Agency, "UNCLASSIFIED REPORT TO CONGRESS ON THE ACQUISITION OF TECHNOLOGY RELATING TO WE”, CIA Electronic Reading Room, 10 May 1999. Accessed 11 April 2007. http://www.foia.ucia.gov/search.asp

42 Wisconsin Project on Nuclear Arms Control. "Egypt Nuclear, Chemical and Missile Milestones - 19602000." The Risk Report, Vol. 6 Num. 5, October 2000. Accessed 5 April 2007. http://www.wisconsinproject.org/countries/egypt/milestones.htm

43 "NNSA and Egypt to Cooperate on Preventing Nuclear Smuggling," National Nuclear Security Administration, 22 June 2006. NA-06-18. Accessed 8 June 2007. http://www.nnsa.doe.gov/docs/newsreleases/2006/PR_2006-06-22_NA-06-18.htm
} 
Though subsidized prices contribute to some degree of inefficiency in Egypt's energy usage, the Egyptian power sector has achieved gradual improvements in technical performance during the past two decades. Thermal efficiency, for example, improved from less than $30 \%$ around 1985 to $38.9 \%$ in 2000. However, Yehia Abu-Alam of the United Nations' Energy Resources Branch states that, as of 2000, "operational efficiency is below potential because of transmission network constraints and dispatching limitations." ${ }^{44}$ The author continues:

"There is a clear opportunity to reduce per capita consumption of energy resources, and in the process, achieve benefits to the global environment through improved utilisation (or end-use) efficiency. This may be achieved by reducing losses, developing renewable resources, and applying more modem techniques of co-generation.".45

Egypt completed the interconnection of its electric transmission grid with that of Libya in December 1999 and with Jordan and Syria in 2002; construction on a connection with Turkey was completed in 2003, but as of March 2007 it was unclear when the grid would come online. Syria and Lebanon are already interconnected. ${ }^{46}$ The Ministry of Electricity and Energy states that by 2010, Egypt aims to construct new power plants, upgrade existing ones, extend transmission and distribution networks, and construct new energy management centers. ${ }^{47}$

Figure 2. Interconnection of Electric Transmission Grids in the Middle East and North Africa. ${ }^{48}$

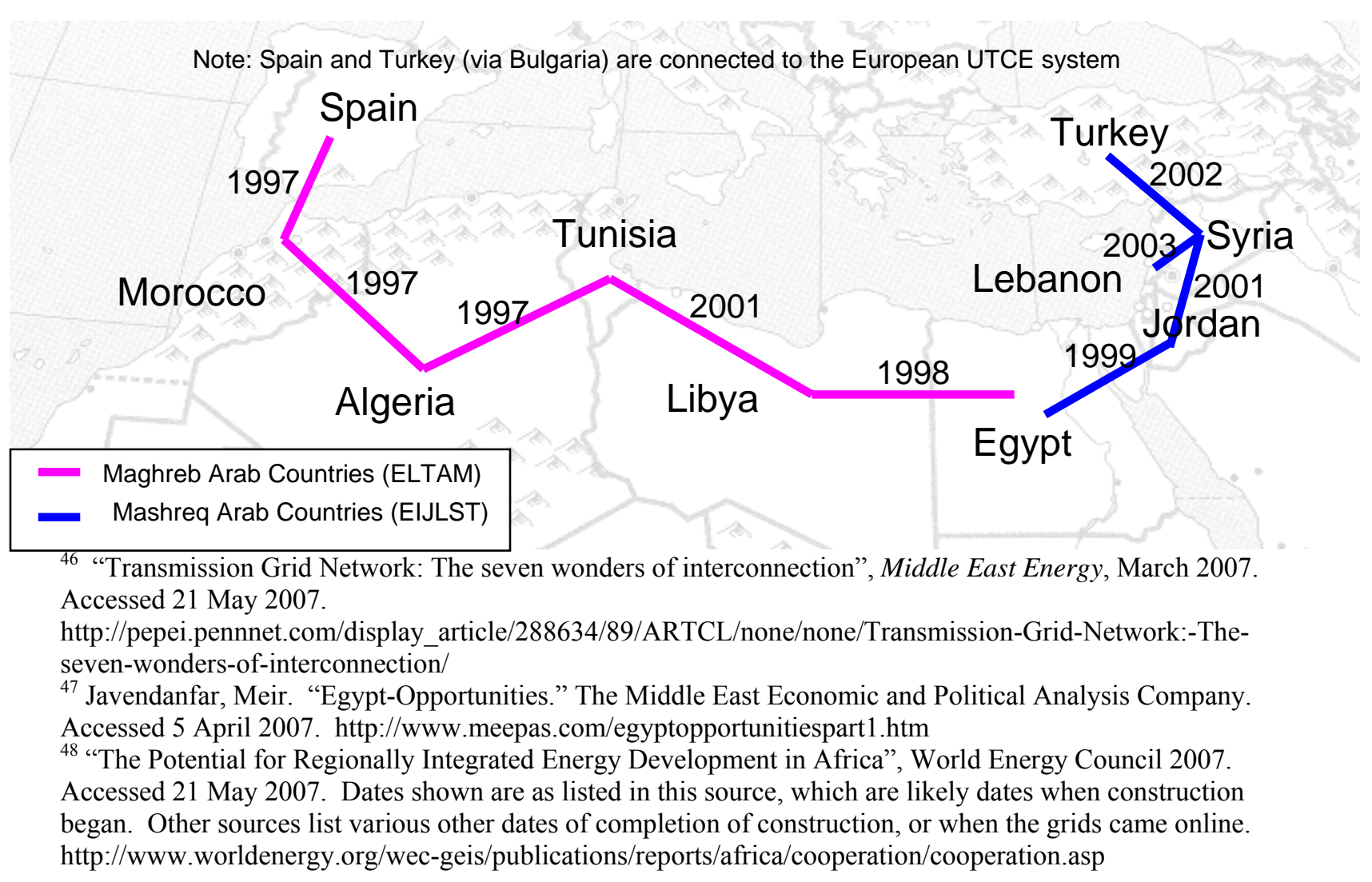


Oil

Egypt produces 700,000 bbl per day (2005 est.) and consumes 590,000 bbl per day. It exports 134,000 bbl per day; petroleum energy exports generate about $10 \%$ of the nation's GDP. ${ }^{49}$ In terms of proved reserves, Egypt has 2.6 billion bbl (2006 est.), which are found primarily in the Gulf of Suez and in the Western Desert. Egypt's oil reserves are steadily declining, and its oil production is also declining, with output of no more than $600,000 \mathrm{bbl}$ per day in 2005 , down from more than $900,000 \mathrm{bbl}$ per day in less than a decade. ${ }^{50}$ The Egyptian government plans for the oil sector are aimed at continuing export earnings, reducing subsidies, and meeting Egypt's domestic energy consumption needs. ${ }^{51}$

Figure 3. Oil Production and Consumption, $1965-2005 .{ }^{52}$

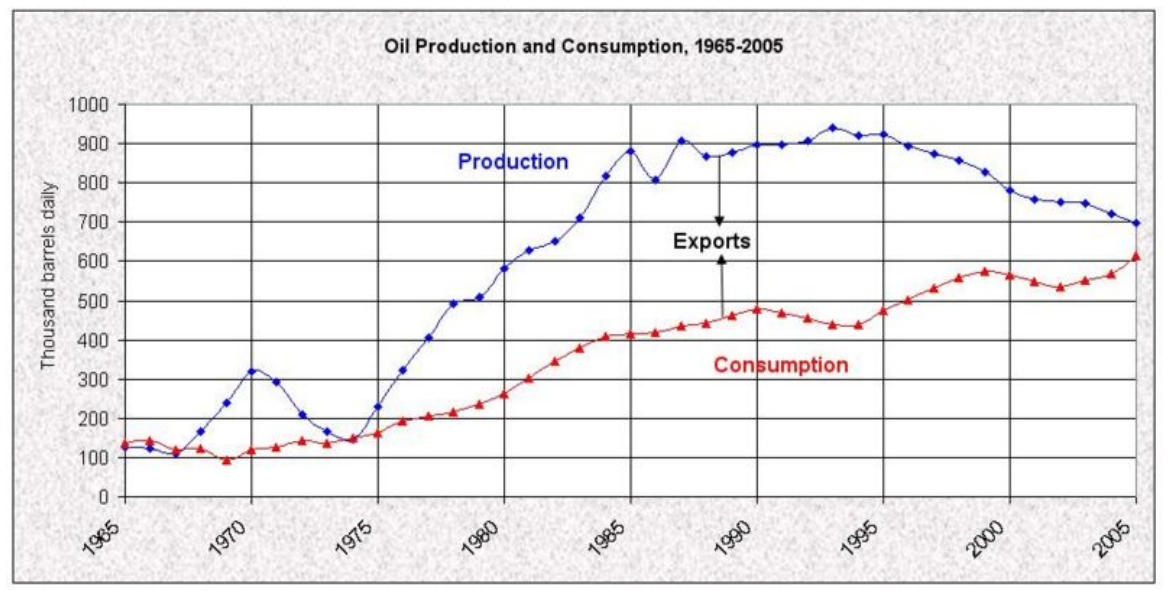

\section{Natural Gas}

Egypt produces 32.56 billion cubic meters of natural gas (2004 est.) and consumes 31.46 billion cubic meters. ${ }^{53}$ Thermal power plants comprise approximately two-thirds of this consumption. Egypt does not import natural gas, and exports 1.1 billion cubic meters, primarily to Jordan, with prospects (as of 2005) of exporting to Turkey, Lebanon, and the Gaza Strip. Proven reserves are found mainly in the Nile Delta, off the Mediterranean Sea shore, and in the Western Desert, and total 1.657 trillion

\footnotetext{
${ }^{49}$ Central Intelligence Agency. "Egypt," The World Factbook. Last updated 15 March 2007. Accessed 5 April 2007. https://www.cia.gov/library/publications/the-world-factbook/geos/eg.html

${ }^{50}$ Business Monitor International, Ltd. "Egypt Oil \& Gas Report Q4 2006,” December 2006. Accessed 6 April 2007. http://www.businessmonitor.com/pdfs/xsumEG02.pdf

${ }^{51}$ Javendanfar, Meir. "Egypt-Opportunities." The Middle East Economic and Political Analysis Company. Accessed 5 April 2007. http://www.meepas.com/egyptopportunitiespart1.htm

${ }^{52}$ Nawar, Abdel-Hameed. The Emerging Landscape of Natural Gas in Egypt. Cairo University, manuscript. 2005

${ }^{53}$ Central Intelligence Agency. "Egypt," The World Factbook. Last updated 15 March 2007. Accessed 5 April 2007. https://www.cia.gov/library/publications/the-world-factbook/geos/eg.html
} 
cubic meters (2005 est.). The Egyptian government plans to maximize natural gas utilization in the domestic market, develop natural gas transportation and distribution systems, and encourage investment in natural gas exploration and development. ${ }^{54}$

Nuclear

Because of declining oil production and limits on natural gas deposits, Egyptian officials have stated Egypt intends to pursue a nuclear power program to provide the energy needed to sustain its growth and development at the same pace. To this end, Russia and China have pledged to help Egypt build and run nuclear reactors. ${ }^{55}$ Also, both the US Ambassador to Egypt and US Secretary of State Condoleezza Rice have offered support for a nuclear energy program in Egypt. ${ }^{56}$

Abdel Hakim Kandil, a nuclear and inorganic chemistry professor at Helwan University in Cairo, said that Egypt would be willing to import and return reactor fuel, so that it would not develop uranium enrichment expertise that could be used to produce weapons material. ${ }^{57}$

\section{INTERNATIONAL TREATY COMMITMENTS AND IAEA COOPERATION}

IAEA Membership and International Treaty Commitments

Egypt has been a member of the IAEA since 1957, and established a comprehensive Safeguards Agreement which took effect in 1982. Egypt has not signed or ratified the Additional Protocol to the IAEA Safeguards Agreement. It signed the NPT in 1981 and ratified it 13 years later, and signed and ratified several other multilateral conventions, which regulate the applications of nuclear energy in the international community. In that regard, Egypt ratified the Vienna Convention on Civil Liability and the Joint Protocol Relating to the Application of the Vienna Convention and Paris Convention. In addition, Egypt signed and ratified the Convention on Early Notification of a Nuclear Accident, and the Convention on Assistance in the Case of a Nuclear Accident or Radiological Emergency. ${ }^{58,59,60}$

\footnotetext{
${ }^{54}$ Javendanfar, Meir. "Egypt-Opportunities." The Middle East Economic and Political Analysis Company. Accessed 5 April 2007. http://www.meepas.com/egyptopportunitiespart1.htm

${ }^{55}$ Douara, Deena. "The Past, Present, and Future of Nuclear Power in Egypt," The Daily Star Egypt, 12

November 2006. Accessed 6 April 2007. http://www.dailystaregypt.com/article.aspx?ArticleID=3902

${ }^{56}$ Sands, Derek. "Analysis: Egypt looks to Russia, China for nuke power," World Peace Herald, 13

November 2006. Accessed 6 April 2007. http://wpherald.com/articles/2119/1/Analysis-Egypt-looks-to-

Russia-China-for-nuke-power/Concerns-over-nuclear-proliferation.html

${ }^{57}$ National Journal Group. "Potential Egyptian Nuclear Program Sparks Concern," Global Security Newswire. National Threat Initiative, 28 March 2007. Accessed 9 April 2007. http://www.nti.org/d newswire/issues/2007 3 28.html

${ }^{58}$ International Atomic Energy Agency. "The Text of the Agreement Between Egypt and the Agency for the Application of Safeguards in Connection with the Treaty on the Non-Proliferation of Nuclear Weapons.” INFCIRC/302. July 1983.

${ }^{59}$ International Atomic Energy Agency. "Strengthened Safeguards System: Status of Additional Protocols," 22 March 2007. Accessed 5 April 2007. http://www.iaea.org/OurWork/SV/Safeguards/sg_protocol.html
} 
Egypt signed the Limited (Partial) Test Ban Treaty on 8 August 1963, and ratified it on 10 January 1964. Egypt signed the Comprehensive Test Ban Treaty on 14 October 1996, but it has not yet ratified the treaty. Both signature and ratification are required for the treaty to enter into force. ${ }^{61,62}$

A summary of the international nuclear agreements Egypt has made is found in the table in Appendix A.

Egypt's legal framework for managing a nuclear power program is not complete. Though it is an active participant in the IAEA community, it has not ratified important agreements on physical protection of nuclear material and spent fuel management, and it has signed, but not ratified, the Convention on Nuclear Safety. For a full list of Egypt's adherence to multilateral agreements and safeguards agreements, see Appendix B.

\section{IAEA Technical Cooperation Projects}

Egypt is currently involved in 22 national TC projects, 38 regional projects, and 8 interregional projects. ${ }^{63}$ These projects include studies on the use of environmental isotopes for pollution treatment, radiation protection and safety, uranium resources development, medical physics, legislative assistance for safe and peaceful uses of nuclear energy, and human resource development, as well as many others. The 2005 Country Overview for Egypt states that the TC program has developed projects in water resource management, comparative assessment of energy options and uranium exploration, production of radioisotopes and radiopharmaceuticals, radiation safety and waste management, and safety of nuclear facilities. In the water sector, for example, a regional assessment of groundwater resources was conducted for reclamation of new lands along the Nile flood plain. In food and agriculture, improvements have been made in animal science, desert development, and crop mutation breeding techniques for higher agricultural productivity, better nutrition, and greater tolerance to stress such as drought and salinity. Irradiation technology is also being used for wastewater treatment, to enhance soil fertility, and for the sterilization of medical products. ${ }^{64}$

The Desert Development Using Nuclear Techniques Project focuses on the following areas:

- Selection of improved plant varieties suited to desert conditions of drought, salinity and poor soil using radiation-induced mutations and biotechnology.

- Biofertilizers in newly reclaimed desert areas.

- Water management in irrigation of desert soil.

\footnotetext{
${ }^{60}$ IAEA Department of Nuclear Energy, "Country Nuclear Power Profiles: Egypt”, last updated Aug. 2005. Accessed 5 April 2007. http://wwwpub.iaea.org/MTCD/publications/PDF/cnpp2004/CNPP_Webpage/countryprofiles/Egypt/Egypt2005.htm ${ }^{61}$ Bureau of Verification, Compliance, and Implementation, U.S. Department of State. "Treaty Banning Nuclear Weapon Tests in the Atmosphere, in Outer Space, and Under Water." Accessed 9 April 2007. http://www.state.gov/t/ac/trt/4797.htm\#signatory

${ }^{62}$ CTBTO Preparatory Commission. "Status of Signature and Ratification." 2007. Accessed 9 April 2007. http://www.ctbto.org

${ }^{63}$ International Atomic Energy Agency, "Information Records on Egypt.” Accessed 5 April 2007. http://www-tc.iaea.org/tcweb/regionalsites/africa/country/default.asp?cid=EGY

${ }^{64}$ International Atomic Energy Agency, "Country Overview for Egypt," 2005. Accessed 5 April 2007. http://www-tc.iaea.org/tcweb/regionalsites/africa/documents/EGY2005.pdf
} 
- Selection of local and/or imported animals that can sustain the harsh desert environment.

- Insect sterile techniques for eradication of some harmful insects.

- Molecular biology approach to pest control.

- Development of building to suit desert conditions (solar passive buildings).

\section{REGIONAL PROJECT POSSIBILITIES}

As Egypt and Jordan already enjoy close economic ties, future export of electricity to Jordan and Maghreb nations (Egypt, Algeria, Tunisia, Morocco, Libya) is among viable possibilities for regional project collaborations. Jordan's King Abdullah II recently called for "an Arab centre for the peaceful use of atomic energy," which Egypt could host or provide consultation and support. ${ }^{65}$ Egypt's technical expertise for the region could allow it to become a regional center for nuclear research as well, with other Arab nations sending scientists to train using Egypt's nuclear facilities, and learning from Egypt's greater developed nuclear infrastructure. Libya, Saudi Arabia, and the Gulf Cooperation Council (Bahrain, Kuwait, Oman, Qatar, Saudi Arabia, and United Arab Emirates) are among nations which could most benefit from such an arrangement.

\footnotetext{
65 "UN Nuclear Chief to Visit Jordan," Yahoo News quoting Agence France-Presse. 1 April 2007. Accessed 9 April 2007.

http://news.yahoo.com/s/afp/20070401/wl_mideast_afp/jordaniaeanuclear_070401130912
} 


\section{JORDAN}

Overview

Jordan is a small Arab country with insufficient supplies of water, oil, and other natural resources. In fact, USAID states that Jordan is one of the ten most water-deprived countries in the world. ${ }^{66}$ About the size of the state of Indiana, Jordan ranks $110^{\text {th }}$ in land area among the countries of the world, and only about $3 \%$ of its land is arable. Jordan's population is just under 6 million people, almost half of whom are refugees from Palestine and, more recently, from Iraq. The population is 92\% Sunni Muslim, and 98\% of the people are Arab by ethnicity. Jordan's nominal GDP per capita of $\$ 4,900$ ranks $132^{\text {nd }}$ in the world, which is less than half of the world average of $\$ 10,000$. Poverty, unemployment, and inflation have been fundamental problems for economic growth, but broad economic reforms in the past decade have made a major difference. In 2006, Jordan's GDP real growth rate was $6 \%$ and it reduced its debt to GDP ratio significantly, though public debt remains quite high at $72.2 \%$ of the GDP. Jordan is $3^{\text {rd }}$ in the world for military expenditures as a percentage of GDP at 10.6\%. Jordan has low energy consumption per capita, about $1,420 \mathrm{kWh}$ compared to $12,454 \mathrm{kWh}$ in the U.S. or 2,962 $\mathrm{kWh}$ for the world average. The government's plans for Jordan's near future include focusing on political reforms, improving conditions for the poor, and fighting corruption, while reducing dependence on foreign grants and promoting job creation. ${ }^{67}$ (CIA Factbook 2007, USAID 2006)

Jordan is interested in developing nuclear energy, as it has virtually no domestic energy resources. It imports $95 \%$ of its energy needs. ${ }^{68}$ The country is active in the international nuclear energy and nonproliferation communities. Nuclear energy could be an asset to Jordan's effort to improve its economy once established, but the country lacks the infrastructure at present to develop it. Jordan has developed virtually none of the required technology for instituting a nuclear energy program. According to a government official who heads a nuclear council, Jordan is trying to reach agreements on nuclear cooperation with the United States, European Union, Canada and possibly other countries. ${ }^{69}$ During recent visits to Jordan, the IAEA indicated it would help Jordan establish its nuclear program. ${ }^{70}$ In April, Jordan's parliament passed legislation to authorize the use of nuclear energy in production of electricity and desalination of water. Collaboration with neighboring Arab nations on such nuclear facilities, particularly Egypt, could benefit Jordan.

\section{NUCLEAR INFRASTRUCTURE/INTENTIONS}

\section{Infrastructure}

\footnotetext{
${ }^{66}$ USAID. “Asia and the Near East: Jordan,” 3 June 2005. Accessed 17 April 2007. http://www.usaid.gov/locations/asia_near_east/countries/jordan/jordan.html

${ }^{67}$ Central Intelligence Agency. "Jordan," The World Factbook. Last updated 15 March, 2007. Accessed 5 April, 2007. https:/www.cia.gov/library/publications/the-world-factbook/geos/jo.html

${ }_{68}^{68}$ Monday Morning Beirut Lebanon, Issue 1795, May 21, 2007.

${ }^{69}$ Ibid.

${ }^{70}$ Ibid.
} 
Knowledge management

Jordan has a labor force of 1.512 million people, of whom only $13 \%$ work in industry. The emphasis on services in Jordan's economy is striking: $83 \%$ of the labor force works in services and $67 \%$ of their GDP also originates from this sector. Approximately $30 \%$ of the labor force is unemployed, but Jordan touts a high literacy rate of over $91 \%$ of people over age 15 who can read and write. (CIA Factbook 2007)

Some Jordanian universities offer physics programs with courses in nuclear physics. For example, the curriculum for a Master's Degree in Physics at Al-Balqa' Applied University requires courses in "Experimental Nuclear Measurements" and "Advanced Nuclear Physics."71 Professor Yacoub Salim Masa'efah of Mu'tah University in Amman conducts research on experimental nuclear physics entitled "Prompt Gamma Rays from Fission Fragments." 72 The faculty of the University of Jordan's Department of Physics conducts research on Accelerator Physics and Medical Physics, including nuclear reactions and radiation protection. ${ }^{73}$ Coursework in nuclear physics and radiation physics is also offered at The Hashemite University. ${ }^{74}$ Other universities offer degrees in physics, but with no clear coursework or background in nuclear physics. However, the domestic educational program in nuclear physics seems limited to a few decentralized university classes, and lacks the ability to train a workforce in nuclear energy development and management. Adequate nuclear education would have to be obtained internationally.

\section{Uranium Resources}

Several surface uranium occurrences have been found in central, southern, and south-eastern Jordan. Results of channel sampling in central Jordan have indicated uranium contents ranging from 140 to $2,200 \mathrm{ppm}$, with total uranium content for two of the four explored blocks in central Jordan estimated at 37,500 tons uranium. The content for the other two blocks has not yet been estimated because of a cessation of uranium exploration in 1998 due to Jordan's National Regulatory Authority (NRA) policy and priorities. In terms of unconventional resources, a total of approximately 70,000 tons uranium is associated with phosphate deposits. In 1982, a feasibility study indicated the potential for uranium extraction from phosphoric acid, but the fall of uranium prices in the late 1980s made this process uneconomic. ${ }^{75}$ However, the uranium spot price has risen from $\$ 23 / \mathrm{lb}$ in 1982 to over $\$ 120 / \mathrm{lb}$ today which may change the economics. The NRA cites "providing technical information on uranium deposits in Jordan to an interested Canadian company" as one of its main objectives for increasing domestic investment. ${ }^{76}$

The Associated Press recently cited an estimate of Jordan's Energy Minister, Khaled al-Shraydeh, that Jordan has 80,000 tons of uranium, and that Jordan's phosphate

\footnotetext{
${ }^{71} \mathrm{Al}$-Balqa' Applied University, http://dar.bau.edu.jo/study_plans/physics.htm

${ }^{72}$ Mu'tah University, http://www.mutah.edu.jo/

${ }^{73}$ University of Jordan, Department of Physics. http://www.ju.edu.jo/sci/phys/index.htm

${ }^{74}$ The Hashemite University, Department of Physics, "Master's Program in Applied Physics."

http://www.hu.edu.jo/Inside/Academics/Sciences/master_phys.doc

${ }^{75}$ Joint Report by the OECD Nuclear Energy Agency and the International Atomic Energy Agency. Uranium 2005:Resources, Production, and Demand, Paris: OECD Publishing, 2005. p. 215-9.

${ }^{76}$ Natural Resources Authority. Annual Report 2004. Accessed 9 April 2007. http://www.nra.gov.jo/side.htm
} 
reserves contain some 100,000 tons of uranium. Al-Shraydeh asserted that this quantity

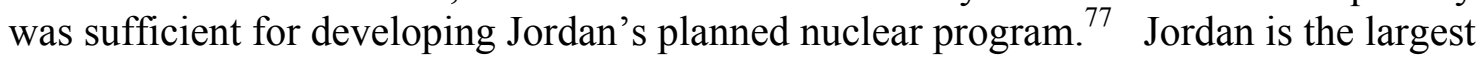
phosphate exporter in the world, but new environmental regulations establish limits on the amount of thorium and uranium in phosphate designated for agricultural use. This requirement makes it expedient for either Jordan or the customer to extract this material. The cost is about $\$ 60 / 1 \mathrm{~b} \mathrm{U}_{3} \mathrm{O}_{8}$, which was prohibitively expensive until the recent spike in uranium prices. A Jordanian source has been cited in the press as stating that Jordan wanted to extract the necessary uranium for nuclear power plants from its estimated 1.2 billion tons of phosphate reserves. ${ }^{78}$

\section{Nuclear Reactors and Fuel Facilities}

Jordan has no nuclear reactors or fuel facilities. The IAEA has collaborated with Jordan in Technical Cooperation projects to establish a nuclear science laboratory beginning several decades ago, but their nuclear program remains rather undeveloped, focusing mainly on basic radiation detection and protection. ${ }^{79}$

$\underline{\text { Regulation }}$

Jordan's Ministry of Energy and Mineral Resources, established in 1984, includes a Nuclear Energy Department. The Jordan Atomic Energy Commission (JAEC), established in 2001, is the main Jordanian partner with the IAEA for all nuclear research and training. The objectives of the JAEC include the following: improving nuclear technology in Jordan; increasing collaboration in nuclear energy research; ensuring compliance with requirements for public safety, radiation prevention, and environmental safety; providing infrastructure; directing R\&D efforts towards nuclear energy technology and nuclear applications in the fields of agriculture, industry, medicine, generating electricity, and water desalination. The Ministry of Energy and Mineral Resources cites the main accomplishments of the JAEC for 2005 as primarily in the fields of radiation control and safety. ${ }^{80}$

Intentions

King Abdullah II stated to the media in January 2007 that Jordan is "looking at nuclear power for peaceful and energy purposes," $"$ and at the Arab summit in late March, the King advocated the establishment of a "Peaceful Arab Center for Using Nuclear Energy." In February, the Energy Minister, Khaled Sharida, announced that

\footnotetext{
77 "Jordan has uranium to build a reactor", Associated Press, Amman: 5 May 2007. Accessed 10 May 2007, via The Jerusalem Post, www.jpost.com

${ }^{78}$ Monday Morning Beirut Lebanon Issue No.1795 Monday, May 21, 2007

79 International Atomic Energy Agency. "IAEA-TC Projects by Country: Jordan.” Accessed 9 April 2007. http:/www-tc.iaea.org/tcweb/tcprogramme/projectsbycountry/query/default.asp

${ }^{80}$ Ministry of Energy and Mineral Resources, “Annual Report 2005.” Accessed 17 April 2007. http://www.memr.gov.jo/TaqaE2005.pdf

${ }^{81}$ Eldar, Akiva. "King Abdullah to Haaretz: Jordan aims to develop nuclear power," Haaretz. 20 January 2007. Accessed 9 April 2007. http://www.haaretz.com/hasen/spages/815304.html
} 
Jordan plans to build its first nuclear power plant by 2015. The produced energy is intended for use in electricity and desalination. ${ }^{82}$

Natural energy resources are extremely scarce within Jordan's borders, so it has turned toward alternative forms of energy to fulfill its needs. Currently Jordan imports almost all its energy resources in the form of gas and oil, and produces a very small amount of energy from renewable resources. Jordan has a high population growth rate of $2.49 \%,{ }^{83}$ and due to economic growth and increasing population, energy demand is expected to increase by at least $50 \%$ over the next 20 years. ${ }^{84}$ Jordan is limited not just by its insufficient domestic resources, but also by constraints on its ability to import energy sources. Due to limitations on the carrying capacity of the Arab Gas pipeline, which imports gas from Egypt, the Jordan Electricity Regulatory Commission (ERC) predicts that "the allocation for Jordan may well not be sufficient to meet the gas burn required for electricity" by 2014. Consequently, the ERC recommends increasing the pipeline transfer capacity if possible; discovering and developing local resources such as gas, oil shale, and oil; considering alternative sources of imported gas; and considering the economic possibilities of wind and solar energy. ${ }^{85}$ Nuclear energy could also provide a domestic energy resource, decreasing Jordan's dependence on importing energy, and any energy generated could provide a needed boost to the industrial economy.

Because of Jordan's limited natural fresh water resources, water desalination is another attractive option for nuclear energy capability (See Appendix Q).

Nuclear energy would make a significant impact on their energy situation, which could impact its access to water and decrease its dependence on imports, thus stimulating the domestic economy. Yet Jordan lacks the technical capability to develop a nuclear energy program. Though biofuels, solar power, wind power, and underground thermal power are all mentioned as possible renewable energy sources to explore by 2015, the 2005 Annual Report of the Ministry of Energy and Mineral Resources does not mention nuclear energy at all. ${ }^{86}$ Jordan's ERC recognizes that nuclear energy is not feasible in the near term because of the technical obstacle to the implementation of nuclear energy. "Conventional nuclear reactors are of too great a size for the Jordan system, are expensive and also have extra costs such as de-commissioning.... A commercial-sized plant is still along way off. This could be a long-term option however, if the technology is developed." 87 As King Abdullah II recently promised to make his nation a model for the Middle East in developing nuclear energy resources, news media reported the IAEA

\footnotetext{
${ }^{82}$ Stern, Yoav. “Jordan announces plans to build nuclear power plant by 2015,” Haaretz. 2 April 2007. Accessed 9 April 2007. http://www.haaretz.com/hasen/spages/844962.html

${ }^{83}$ Central Intelligence Agency. “Jordan," The World Factbook. Last updated 15 March, 2007. Accessed 5 April, 2007. https:/www.cia.gov/library/publications/the-world-factbook/geos/jo.html

${ }^{84}$ Ministry of Energy and Mineral Resources. “Jordan’s Energy Master Plan.” Accessed 11 April 2007. http://www.memr.gov.jo/

${ }^{85}$ Jordan Electricity Regulatory Commission. "Development of a Masterplan for the Electricity Sector: Generation and Transmission Expansion, Final Report," March 2006. Accessed 10 April 2007. http://www.erc.gov.jo/english/masterp.pdf

${ }^{86}$ Ministry of Energy and Mineral Resources, “Annual Report 2005.” Accessed 17 April 2007. http://www.memr.gov.jo/TaqaE2005.pdf

${ }^{87}$ Jordan Electricity Regulatory Commission. "Development of a Masterplan for the Electricity Sector: Generation and Transmission Expansion, Final Report," March 2006. Accessed 10 April 2007. http://www.erc.gov.jo/english/masterp.pdf
} 
Director General as saying the IAEA "was ready to help Jordan to benefit from nuclear energy for peaceful purposes." $\$ 8$

When referencing nuclear energy prospects, Jordan continually reiterates its peaceful energy intentions. Historically, Jordan has advocated a weapons of mass destruction free Middle East. The nation is uneasy about Israel as a nuclear power, and continues to demand that Israel become a signatory to the Nonproliferation Treaty (NPT) and that it allow inspections of its nuclear reactors. ${ }^{89}$ More recently Jordan has also become more troubled by prospects of Iran as a nuclear power, with fears that any potential US military involvement in Iran would have negative effects on Jordan; there is some speculation that Jordan's interest in a nuclear program has been catalyzed by Iran's prominent and substantial nuclear intentions. Publicly Jordan has shown no motivation for developing any nuclear weapons program.

In any case, Jordan is quite far from the technical capability of developing a nuclear program of any kind. News media reported that a visit to Jordan by the Pakistani President in late January 2007 led to a "Pakistani promise for technical assistance in the construction of a peaceful nuclear reactor," ${ }^{, 90}$ but as yet there has been no further work in this direction. Jordan has strong import controls, but its export regime may be less stringent. In 1994, Amy Kaslow reported in the Christian Science Monitor, "U.S. Customs Service Senior Special Agent Thomas Madigan said that, 'Jordan has served as the primary point of diversion for illegal smuggling into Iraq since implementation of the [UN] embargo." "91 Concerns about the strength of border controls arose because Jordan is a key link in the transport of goods between the East and West. Jordan is a member of the World Trade Organization and was the first Arab nation to sign a Free Trade Agreement with the U.S. in $2001 .{ }^{92}$ U.S. and EU technical assistance in export controls led Jordan to adopt the EU control list as its national control list in February 2007. ${ }^{93}$

\section{ECONOMIC}

\section{Electricity}

Jordan produces 8.431 billion $\mathrm{kWh}$ of electricity and consumes 8.387 billion $\mathrm{kWh}$, exporting 4 million $\mathrm{kWh}$ annually and importing 550 million $\mathrm{kWh} .{ }^{94}$ Almost all of

\footnotetext{
${ }^{88}$ Gavlak, Dale. "More Mideast States Eyeing Nuclear Power," Associated Press. New York Times, 15 April 2007.

89 "'UN Nuclear Chief to Visit Jordan," Yahoo News quoting Agence France-Presse. 1 April 2007. Accessed 9 April 2007.

http://news.yahoo.com/s/afp/20070401/wl_mideast_afp/jordaniaeanuclear_070401130912

${ }^{90}$ Hilal, Khalid and Leah Kuchinsky. "Jordan Joins List of Arab States Announcing Nuclear Energy Programs; Pakistan Promises Help," WMD Insights, Monterey Institute Center for Nonproliferation Studies. Accessed 10 April 2007. http://www.wmdinsights.org/I13/I13_ME1_JordanJoins.htm

${ }^{91}$ Kaslow, Amy. "US Turns Blind Eye To Jordan's Breach Of Sanctions On Iraq," Christian Science Monitor, 18 July 1994. Accessed 17 April 2007. http://www.csmonitor.com/1994/0718/18011.html

${ }^{92}$ Bureau of Near Eastern Affairs, US Department of State. "Background Note: Jordan," October 2006. Accessed 17 April 2007. http://www.state.gov/r/pa/ei/bgn/3464.htm

${ }^{93}$ U.S. Dept of State EXBS program; http://www.exportcontrol.org/library/1073/EXBSslideShow.pdf.

${ }^{94}$ Central Intelligence Agency. "Jordan," The World Factbook. Last updated 15 March, 2007. Accessed 5 April, 2007. https://www.cia.gov/library/publications/the-world-factbook/geos/jo.html
} 
its domestic electricity production uses imported oil or gas. Jordan's demand for electricity has grown at the swift annual rate of $7.7 \%$ in recent years. ${ }^{95}$

Figure 1. Generated and Imported Electrical Energy in Jordan Compared to Energy Consumed $(\mathrm{GWh})^{96}$

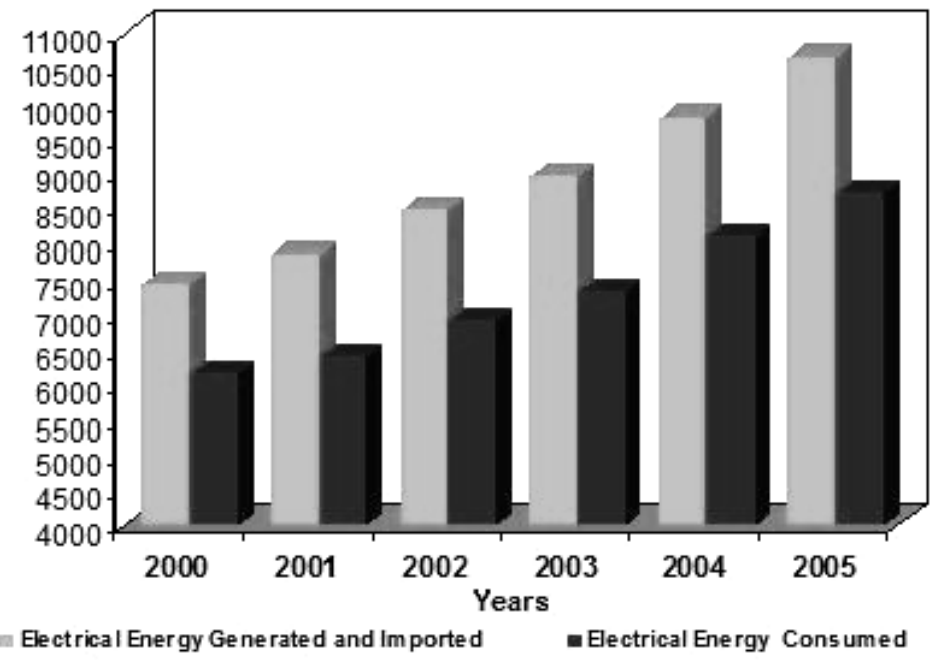

The ERC has proposed several ways to improve the use of the electricity it already generates. Jordan's Ministry of Energy and Mineral Resources cited international studies showing the possibility of improving energy use efficiency by up to $15 \%$ in the first five years of implementing energy efficiency programs or up to $3 \%$ annually. ${ }^{97}$ Security of the electricity supply could be increased by further developing the EJILLST (Egypt, Jordan, Iraq, Lebanon, Libya, Syria and Turkey) project that connects the electric grid systems of these countries, and Jordan particularly seeks to reinforce its connections with its close neighbors Egypt and Syria. ${ }^{98}$ Energy losses in transmission have increased over the past few years despite improvements to the national grid; the ERC suspects illegal connections to the network and suggests monitoring transmission lines more closely to limit loss. ${ }^{99}$ The government provides subsidies to encourage efficient energy use of about $10 \%$ for small industry, $20-40 \%$ for water pumping and agriculture and over

\footnotetext{
${ }^{95}$ Electricity Sector Regulatory Commission. "The Annual Report 2005,” 2005. Accessed 10 April 2007. http://www.erc.gov.jo/english/report.doc; Ministry of Energy and Mineral Resources. http://www.memr.gov.jo/

${ }^{96}$ National Electric Power Co. "Reports and Statistics - Technical Statistics: Electrical Energy in Jordan." Accessed 11 April 2007. http://www.nepco.com.jo/english_tstatic5.html

${ }^{97}$ Ministry of Energy and Mineral Resources. "National Energy Efficiency Strategy," January 2007. Accessed 9 April 2007. http://www.memr.gov.jo/National\%20Energy\%20Efficiency\%20Strategy.pdf 98 Jordan Electricity Regulatory Commission. "Development of a Masterplan for the Electricity Sector: Generation and Transmission Expansion, Final Report," March 2006. Accessed 10 April 2007. http://www.erc.gov.jo/english/masterp.pdf

${ }^{99}$ Electricity Sector Regulatory Commission. "The Annual Report 2005," 2005. Accessed 10 April 2007. http://www.erc.gov.jo/english/report.doc
} 
$90 \%$ for street lighting, ${ }^{100}$ and perhaps these subsidies could be adjusted to develop even greater energy use efficiency. The Ministry of Electricity and Mineral Resources also plans to encourage private investment in electricity generation and distribution.

Jordan collaborates on electricity resources with several neighboring countries. It connected to Syria's transmission grid in 2001. This was later interconnected with Lebanon, and to that of Egypt in 1999. Egypt's transmission grid was connected to that of Libya in 1998. Construction for a connection with Turkey's grid was completed in 2002, but as of March 2007 it was unclear when it would come online. ${ }^{101}$ A summary of the international connections among electricity grids are found in Figure 2.

Figure 2. Interconnection of Electric Grids in the Middle East and North Africa. ${ }^{102}$

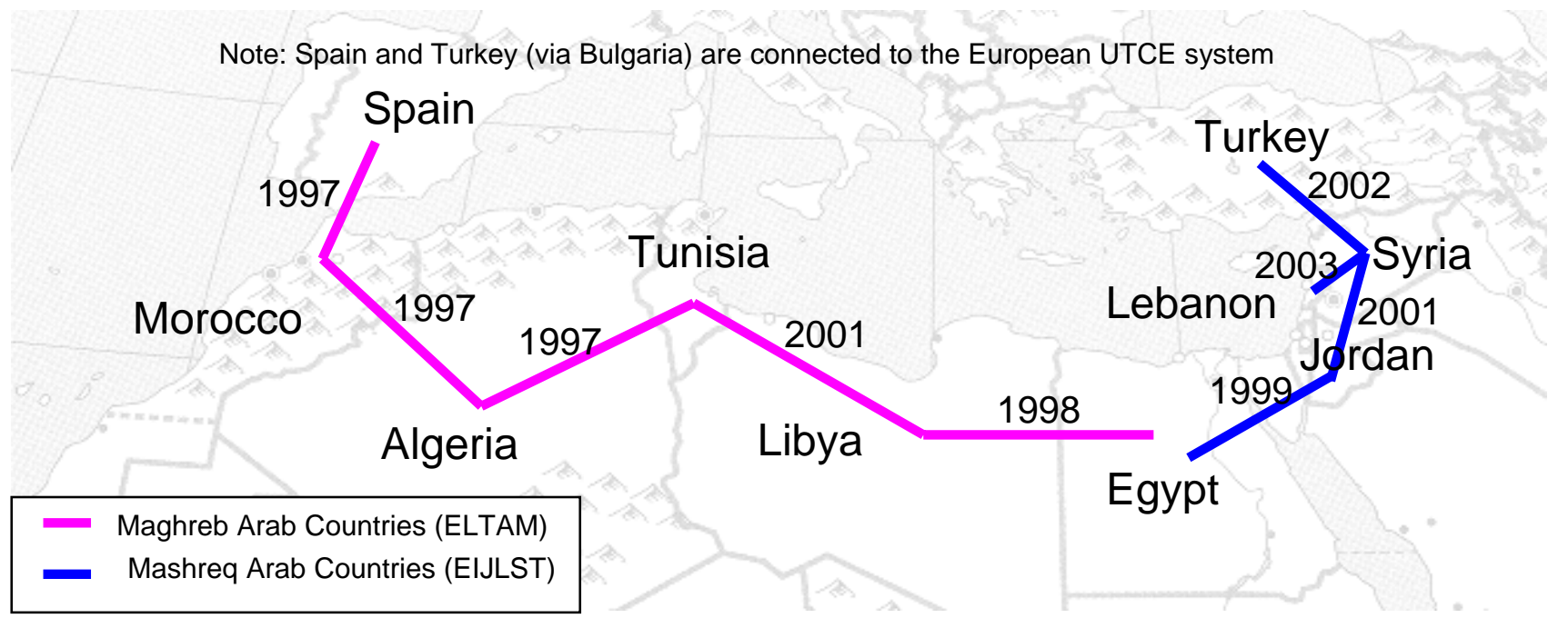

Moreover, Jordan is actively considering alternative energy resources such as solar, wind and hydropower for electricity generation. Currently, renewable energy resources constitute about $14 \mathrm{MW}$ of power, generated mostly from wind and hydropower. The ERC notes that Jordan set a target in its Action Plan for the 2004 World Renewable Energy Conference for a total of 5\% of their energy from renewable sources by 2015 , but predicts that a realistic target is $2-3 \%$ by 2015 , due to high costs

\footnotetext{
${ }^{100}$ World Energy Council. "Pricing in Developing Countries - The Case of Jordan: Investment and Growth, Energy Sector," 2007. Accessed 10 April 2007. http://www.worldenergy.org/wecgeis/publications/reports/pedc/cases/jordan.asp

101 "Transmission Grid Network: The seven wonders of interconnection", Middle East Energy, March 2007. Accessed 21 May 2007.

http://pepei.pennnet.com/display_article/288634/89/ARTCL/none/none/Transmission-Grid-Network:-Theseven-wonders-of-interconnection/

102 "The Potential for Regionally Integrated Energy Development in Africa", World Energy Council 2007. Accessed 21 May 2007. Dates shown are as listed in this source, which are likely dates when construction began. Other sources list various other dates of completion of construction, or when the grids came online. http://www.worldenergy.org/wec-geis/publications/reports/africa/cooperation/cooperation.asp
} 
compared to imported natural gas. Jordan intends to focus on wind and biomass for renewable resources. ${ }^{103}$

\section{Oil}

Jordan has no domestic oil production. As of January 2002, Jordan's proven reserves of oil total $445,000 \mathrm{bbl}$, which is less than half the country's daily consumption of 107,000 bbl per day. Almost all of Jordan's oil must be imported. ${ }^{104}$ All of Jordan's oil needs are imported from Saudi Arabia, as per trade agreements. ${ }^{105}$

The continual cost of imported oil has consumed between 6-10\% of Jordan's GDP, depending on oil prices. ${ }^{106}$ Jordan once imported most of its oil from Iraq, but beginning in 2003, the effects of the US-Iraq War have required Jordan to become more dependent on oil from other Gulf nations. As a result, the Jordanian government has raised retail petroleum product prices and the sales tax base.

Nearly 40 billion tons of oil shale can be found within Jordan's territory, ${ }^{107}$ and the Natural Resources Authority is looking towards the possibility of developing and exploiting its oil shale deposits. Potential for this resource is still being examined in feasibility studies and economic evaluations. ${ }^{108}$

\section{Natural Gas}

Jordan has limited natural gas resources, and imports almost all its natural gas. It produces 310 million cubic meters of natural gas annually, consumes 1.41 billion cubic meters, and imports 1.1 billion cubic meters, primarily from Egypt. Jordan is estimated to have 6.23 billion cubic meters of reserves of natural gas. (CIA Factbook 2007)

\section{INTERNATIONAL TREATY COMMITMENTS AND IAEA COOPERATION}

\section{IAEA Membership and International Treaty Commitments}

Jordan became a member of the IAEA on 18 April 1966. It signed the Additional Protocol to the IAEA Safeguards Agreement on 28 July 1998, and it took effect on the same date; Jordan is the only country in the Middle East to have an Additional Protocol in

\footnotetext{
103 Jordan Electricity Regulatory Commission. "Development of a Masterplan for the Electricity Sector: Generation and Transmission Expansion, Final Report,” March 2006. Accessed 10 April 2007. http://www.erc.gov.jo/english/masterp.pdf

${ }^{104}$ Central Intelligence Agency. "Jordan," The World Factbook. Last updated 15 March, 2007. Accessed 5 April, 2007. https://www.cia.gov/library/publications/the-world-factbook/geos/jo.html

${ }^{105}$ Ministry of Energy and Mineral Resources, “Annual Report 2005." Accessed 17 April 2007. http://www.memr.gov.jo/TaqaE2005.pdf

${ }^{106}$ World Energy Council. "Pricing in Developing Countries - The Case of Jordan: Investment and Growth, Energy Sector," 2007. Accessed 10 April 2007. http://www.worldenergy.org/wecgeis/publications/reports/pedc/cases/jordan.asp 107 Ibid.

${ }^{108}$ Natural Resources Authority. Annual Report 2004. Accessed 9 April 2007. http://www.nra.gov.jo/side.htm
} 
force. Jordan has qualified and has been approved for the Small Quantities Protocol as well. ${ }^{109,110,111,112}$

Jordan signed the Treaty on Nuclear Non-Proliferation in 1968 and ratified it in 1970. The Convention on Nuclear Safety was signed in 1994 but Jordan has not yet ratified it. ${ }^{113}$

Jordan signed the Partial Test Ban Treaty on 12 August 1963 and ratified it on 29

May 1964. It signed the Comprehensive Test Ban Treaty on 26 September 1996 and ratified this treaty on 25 August 1998. ${ }^{114,115}$

Jordan has established some of the legal framework necessary for the peaceful use of nuclear materials, equipment and technology. The framework is fairly solid compared to the fact that Jordan has so few nuclear programs or materials to safeguard anyway. However, the country has not become party to several international agreements needed to assure international confidence in its nuclear work, including agreements on the physical protection of nuclear material, spent fuel management, and civil liability, and nuclear safety. For a full list of Jordan's international nuclear commitments, see Appendix C.

\section{IAEA Technical Cooperation Projects}

Jordan has participated in a total of 55 national Technical Cooperation (TC) projects with the IAEA. These projects have focused on a variety of nuclear-related topics including radiation protection; nuclear energy planning, first commenced in 1982; establishment of a nuclear information center and nuclear research facility; uranium exploration; uranium extraction from phosphoric acid; training in research reactor simulation techniques "as a preparatory step towards the possible acquisition of a small research reactor"; radiation therapy; emergency planning, preparedness, and response to radiological emergencies; and import controls on radioactive sources and materials. ${ }^{116}$ Jordan also initiated a TC project to establish a low-power research reactor facility for

\footnotetext{
${ }^{109}$ International Atomic Energy Association, "Protocol Additional to the Agreement Between the Hashemite Kingdom of Jordan and the International Atomic Energy Agency for the Application of Safeguards in Connection with the Treaty on the Non-Proliferation of Nuclear Weapons," IAEA Information Circular, INFCIRC/258, August 1998. Accessed 11 April 2007. http://www.iaea.org/Publications/Documents/Infcircs/1998/infcirc258a1.shtml

${ }^{110}$ International Atomic Energy Agency. "Strengthened Safeguards System: Status of Additional Protocols," 22 March 2007. Accessed 10 April 2007. http://www.iaea.org/OurWork/SV/Safeguards/sg protocol.html

${ }^{111}$ ElBaradei, Mohamed. "The Peaceful Use of Nuclear Energy: The Contribution of the IAEA," 15 December 2002. Accessed 10 April 2007. http://www.iaea.org/NewsCenter/Statements/2002/ebsp2002n011.shtml

${ }^{112}$ International Atomic Energy Agency. "Safeguards Current Status", 16 May 2007. Accessed 5 June 2007. http://www.iaea.org/OurWork/SV/Safeguards/sir_table.pdf

${ }^{113}$ International Atomic Energy Association. "Convention on Nuclear Energy," 11 May 2006. Accessed 11 April 2007. http://ola.iaea.org/OLA/treaties/multi.asp

${ }^{114}$ Bureau of Verification, Compliance, and Implementation, U.S. Department of State. "Treaty Banning Nuclear Weapon Tests in the Atmosphere, in Outer Space, and Under Water." Accessed 9 April 2007. http://www.state.gov/t/ac/trt/4797.htm\#signatory

${ }^{115}$ CTBTO Preparatory Commission. "Status of Signature and Ratification." 2007. Accessed 9 April 2007. http://www.ctbto.org

${ }^{116}$ International Atomic Energy Agency. "IAEA-TC Projects by Country: Jordan.” Accessed 9 April 2007. http://www-tc.iaea.org/tcweb/tcprogramme/projectsbycountry/query/default.asp
} 
applications in materials analysis, radioisotope production, and training in reactor physics, but this project was cancelled in 2001. In 2007, Jordan commenced two TC projects, one on the establishment of a radioactive waste management program, and the other regarding an assessment of the economic and technical feasibility of a dual-purpose nuclear reactor for power supply and water desalination.

\section{REGIONAL PROJECT POSSIBILITIES}

Jordan has stated interest in collaborating with other Arab nations to develop a nuclear energy. King Abdullah II recently called for "an Arab centre for the peaceful use of atomic energy" in a written speech to the Arab summit meeting in late March $2007 .{ }^{117}$ Jordan could join forces, particularly with Egypt, leaning on Egypt's superior technical capability for research, training workers, and ability to develop a nuclear energy program. Jordan already enjoys close economic ties with Egypt. Trade between Egypt and Jordan has quadrupled in the past few years, but Jordan relies more heavily on Egypt for energy resources and investment funds. ${ }^{118}$ Though Jordan's economy might improve by access to a nuclear energy resource, the country's current limited technical capability argues for a partnership with other more advanced nations to implement its goals of developing nuclear energy.

Jordan's Ministry of Energy and Mineral Resources has affirmed its commitment to "cooperation agreements and memoranda of understanding with many fraternal Arab countries in the field of energy, electricity, and mineral resources. These countries include, but are not limited to, Kingdom of Saudi Arabia, Arab Republic of Egypt, Syrian Arab Republic, Republic of Tunisia, Republic of Algeria, Kingdom of Bahrain, [and] State of Kuwait, [among others]." ${ }^{119}$ The National Electric Company provides training and consulting for Sudan, Yemen, Syria, and Palestine. The Arab Gas Line Project connects Egypt and Jordan, and is planning to be extended through to Syria, Lebanon, and Turkey. A project to connect the electric grids of Jordan, Egypt, Iraq, Syria, Lebanon, Libya, and Turkey is also underway.

117 "UN Nuclear Chief to Visit Jordan," Yahoo News quoting Agence France-Presse. 1 April 2007. Accessed 9 April 2007.

http://news.yahoo.com/s/afp/20070401/wl_mideast_afp/jordaniaeanuclear_070401130912

118 "King counts on Jordan-Egypt economic, trade ties to be model in the region," Jordan Times, 14

January 2005. Accessed 11 April 2007. http://www.jordanembassyus.org/01142005004.htm

${ }^{119}$ Ministry of Energy and Mineral Resources, “Annual Report 2005.” Accessed 17 April 2007. http://www.memr.gov.jo/TaqaE2005.pdf 


\section{TURKEY}

Overview

Turkey is strategically located on the land bridge between Europe and Central Asia. Its population is over 70 million people, ranking the nation $18^{\text {th }}$ in the world. The population is $99.8 \%$ Sunni Muslim. Turkey is $36^{\text {th }}$ in the world by land area, and it has more arable land than most other Middle East nations.

Turkey is a member of the United Nations, and it became a member of NATO in 1952. In 1964, Turkey became an associate member of the European Community. Over the past decade, it has undertaken many reforms to strengthen its democracy and economy, enabling it to begin accession talks with the European Union.

Turkey ranks $94^{\text {th }}$ in the world by nominal GDP per capita at $\$ 8,900$, which is approximately comparable to the world average of $\$ 10,000$. Turkey's economy is burdened by a high current account deficit, high public debt, and high inflation of nearly $10 \%$ annually; however, it has made strong economic gains in recent years, largely due to foreign investments in emerging markets, IMF supports, and tighter fiscal policy. Despite a severe banking and economic crisis in 2001, with the implementation of economic reforms, GDP growth reached $9 \%$ in 2004, and roughly $5 \%$ annual growth for 2005-06. At 5.3\%, Turkey ranks $18^{\text {th }}$ in the world in terms of military expenditures as a percentage of GDP. ${ }^{120}$ (CIA Factbook 2007)

Turkey's energy consumption per capita is about $2,000 \mathrm{kWh}$, compared to 12,454 $\mathrm{kWh}$ in the US or $2,962 \mathrm{kWh}$ for the world average. Because Turkey imports much of its energy supply, and because it seeks to establish an energy policy that encourages sustainable development and renewable energy sources, the country has sought nuclear energy as a viable option. Its complex nuclear infrastructure, complete with a research reactor, fuel facilities, and an extensive knowledge management capacity, provides Turkey with many of the prerequisites needed for developing a nuclear energy program. Turkey has in fact tried building a power facility four times; its primary hindrance is adequate funding. As a member of NATO and an ally of the European Union, Turkey seems to pose a low proliferation threat. Turkey could work with the European Union, the United States, and Israel to fund and to develop a peaceful nuclear energy resource that could help to meet the country's rising domestic energy needs.

\section{NUCLEAR INFRASTRUCTURE/INTENTIONS}

\section{Infrastructure}

Knowledge management

Turkey has a labor force of 24.8 million people, of whom $23 \%$ work in industry. Approximately $10 \%$ of the labor force is unemployed, with an additional $4 \%$ underemployed. Turkey's literacy rate is $86.5 \%$ of the population (defined as age 15 and

${ }^{120}$ Central Intelligence Agency. "Turkey," The World Factbook. Last updated 15 March 2007. Accessed 11 April 2007. https://www.cia.gov/library/publications/the-world-factbook/geos/tu.html 
over who can read and write), yet there is a significant discrepancy between the male and female literacy rates $\left(94.3 \%\right.$ and $78.7 \%$, respectively). ${ }^{121}$ (CIA Factbook 2007)

Several Turkish university programs offer coursework and degrees specifically in nuclear physics and nuclear energy-related fields. Cekmece Nuclear Research and Training Center (CNRTC) was the first nuclear research and training center in Turkey, established in 1961. ${ }^{122}$ The Institute of Nuclear Sciences at Ege University has an extensive Master's and PhD program, and their facilities include laboratories for nuclear fuel and nuclear chemistry research. ${ }^{123}$ A research group in Hacettepe University's Department of Nuclear Engineering, which offers both full undergraduate and graduate programs, conducts research and analysis on gas cooled reactor technologies, especially the Pebble Bed Modular Reactor (PBMR) type reactor. ${ }^{124}$ A full Nuclear Engineering graduate program at Bogazici University also includes research on a Pressurized Water Reactor power plant. ${ }^{125}$ Other nuclear science academic and research programs are found at Middle East Technical University, Dokuz Eylül University, The Scientific \& Technological Council of Turkey (TÜBITTAK), and Istanbul Technical University’s Institute of Energy. ${ }^{126,127,128,129}$ Turkey's nuclear educational and research programs are both detailed and comprehensive. They contribute to a good knowledge base in the country for creating the technical workforce for development and management of nuclear energy.

\section{Uranium Resources}

Economically feasible, "reasonably assured" resources of 9,129 tons uranium are found at five different sites within Turkey's borders, ranging in concentration from $0.05 \%$ to $0.1 \% \mathrm{U}_{3} \mathrm{O}_{8}$. Further exploration for radioactive raw material is planned for the Salakyurt - Kaman region. Turkey does not produce uranium, but the government holds 1.9 tons of natural uranium concentrate. ${ }^{130}$

About 380,000 tons of thorium reserves are also in Turkey. ${ }^{131}$

\footnotetext{
${ }^{121}$ Central Intelligence Agency. "Turkey," The World Factbook. Last updated 15 March 2007. Accessed 11 April 2007. https:/www.cia.gov/library/publications/the-world-factbook/geos/tu.html

${ }^{122}$ Kibaroglu, Mustafa. “Turkey's Quest for Peaceful Nuclear Power," The Nonproliferation Review, Spring-Summer 1997. p. 34-44. Accessed 13 April 2007.

http://cns.miis.edu/pubs/npr/vol04/43/kibaro43.pdf

${ }^{123}$ Institute of Nuclear Sciences. Accessed 12 April 2007. http://nukleer.ege.edu.tr/eng/

${ }^{124}$ Gas Cooled Reactor Project Group, Hacettepe University. Accessed 12 April 2007. http://www.nuke.hacettepe.edu.tr/pbmr/

${ }^{125}$ Graduate Studies in Nuclear Engineering, Bogazici University. Accessed 12 April 2007. http://www.nuce.boun.edu.tr/

${ }^{126}$ Department of Physics, Nuclear Physics, Middle East Technical University. Accessed 12 April 2007. http://www.physics.metu.edu.tr/research/field6.html

${ }^{127}$ Dokuz Eylül University. Accessed 12 April 2007. http:/www.deu.edu.tr/DEUWeb/English/

${ }^{128}$ The Scientific \& Technological Council of Turkey. Accessed 12 April 2007. http://www.tubitak.gov.tr/

${ }^{129}$ Institute of Energy, Istanbul Technical University. 12 April 2007. http://www.energy.itu.edu.tr/EN/dep.htm

${ }^{130}$ Joint Report by the OECD Nuclear Energy Agency and the International Atomic Energy Agency. Uranium 2005:Resources, Production, and Demand, Paris: OECD Publishing, 2005. p. 304-5.

${ }^{131}$ Demirbas, Ayhan. “Options and trends of thorium fuel utilization,” Energy Sources, Vol. 27, n.7. Taylor \& Francis, Philadelphia: 2005. p 597-603.
} 


\section{Nuclear Reactors and Fuel Facilities}

Turkey has attempted to build a nuclear power plant four times since 1973, but has yet to complete the process of planning and construction. Each time, the plans have been cancelled, often for financial reasons. ${ }^{132,133}$ Aside from the cost, the leading internal impediment to nuclear power development in Turkey is now environmental politics, as is the case elsewhere in Europe. Turkey faces earthquake hazards, and critics charge that the proposed plant at Akkuyu is prone to seismic risks. ${ }^{134}$

Nevertheless, Turkey's research program is extensive. Security analysts Bowen and Kidd of King's College London observe that, "Almost all aspects of the nuclear fuel cycle have been examined in Turkey except uranium enrichment." ${ }^{135}$ And despite financial constraints, today, Turkey has one research reactor in operation. It is the ITUTRR, a light-water "TRIGA MARK II" reactor owned by Istanbul Technical University and operated by Turkey's Institute for Nuclear Energy which generates $250 \mathrm{kWh}$ of thermal power. ITU-TRR was built by 1975 and reached criticality 11 March 1979. Maximum thermal neutron flux for the reactor is $8.1 \times 10^{12} \mathrm{n} / \mathrm{cm}^{2}$-s, and its horizontal channels are used for research in neutron radiography and gammagraphy. Fuel for the reactor is enriched and supplied by the United States. Formerly Turkey had two pool reactors in operation, TR-1 and TR-2 at the Çekmece Nuclear Research and Training Center in Istanbul. After it became operational in January 1962, TR-1 generated 1 MW of thermal power with a maximum neutron flux of $5 \times 10^{12} \mathrm{n} / \mathrm{cm}^{2}$-s, but the reactor was shut down in September 1977. It was owned by Turkish Atomic Energy Authority and operated by CNRTC, and all the fuel was enriched and fabricated in the U.S.

TR-2 reached criticality in 1981 and was shut down fourteen years later. Also owned by Turkish Atomic Energy Authority and operated by CNRTC, TR-2 produced thermal power of $5 \mathrm{MW}$ with a maximum thermal neutron flux of $4.9 \times 10^{12} \mathrm{n} / \mathrm{cm}^{2}$-s. Fuel for this facility was enriched by the US and fabricated in France. ${ }^{136}$

Turkey has three former fuel facilities, as well as two that are currently in operation. A pilot plant at the MTA Technology Laboratory in Ankara was built in 1987 for the purpose of uranium recovery from phosphates. It had a design capacity of 0.1 tons uranium per year. The facility was shut down in 1990. At the same location, laboratory-scale uranium ore processing was conducted between 2003 and 2006. The project sought to research $\mathrm{ThO}_{2}$ recovery from Eskisehir Beylikahir Ore. No uranium was produced. This laboratory facility has also been shut down as of 31 March 2006. A

\footnotetext{
${ }^{132}$ IAEA Department of Nuclear Energy, “Country Nuclear Power Profiles: Turkey”, last updated August 2005. Accessed 10 April 2007. http://wwwpub.iaea.org/MTCD/publications/PDF/cnpp2004/CNPP_Webpage/countryprofiles/Turkey/Turkey2004.htm

${ }_{133}$ Birol, Dr. Erdener. "National Energy Outlook of Turkey and Expectations from Nuclear Technology," World Nuclear Association Annual Symposium, London: 4-6 September 2002. p. 2. Accessed 12 April 2007. http://www.world-nuclear.org/sym/2002/pdf/birol.pdf

${ }^{134}$ Lesser, Ian. "Turkey, Iran, and Nuclear Risks," Getting Ready for a Nuclear-Ready Iran. Henri Sokolski and Patrick Clawson, ed. Strategic Studies Institute, October 2005. Accessed 13 April 2007. http://www.strategicstudiesinstitute.army.mil/pdffiles/pub629.pdf

${ }^{135}$ Bowen, Wyn Q. and Joanna Kidd. "The Nuclear Capabilities and Ambitions of Iran's Neighbors", Getting Ready for a Nuclear-Ready Iran. Henri Sokolski and Patrick Clawson, ed. Strategic Studies Institute, October 2005. Accessed 12 April 2007. http://www.strategicstudiesinstitute.army.mil/pdffiles/pub629.pdf

${ }^{136}$ Research Reactor Database. "Nuclear Research Reactors in the World: Egypt." International Atomic Energy Agency, 1999. Accessed 12 April 2007. http://www.iaea.org/worldatom/rrdb/
} 
third facility, a pilot plant owned by the same laboratory but located in ManisaKoprubasi, was built in 1974 and shut down in 1982. The facility was used for uranium ore processing and had a design capacity of 1 ton uranium per year. Using the heap leaching process, the facility converted uranium ore into yellowcake.

The two fuel facilities still in operation are both owned by the Turkish Atomic Energy Authority and operated by CNRTC, which is located in Istanbul. The Conversion Nuclear Fuel Pilot Plant began operation in 1986, and it converts yellowcake to $\mathrm{UO}_{2}$ powder using the D/SX Precipitation / Reduction process. It has a design capacity of 0.1 tons heavy metal per year. The Pellet Production Nuclear Fuel Pilot Plant also began operation in 1986. It uses screening, pressing, and sintering to convert to $\mathrm{UO}_{2}$ powder to sintered $\mathrm{UO}_{2}$ pellets with a design capacity of 0.1 tons heavy metal per year. ${ }^{137}$

Turkey's academics and governments scientists have also conducted research since the late 1980's on reactors and reprocessing. In particular, a research project at Hacettepe University sought to use the solvent extraction process to reprocess thoriumbased spent fuel, in anticipation that Turkey may eventually build a thorium-based High Temperature Reactor. ${ }^{138}$ Currently, the Gas Cooled Reactor Project Group at Hacettepe University is researching a Pebble Bed Modular Reactor (PBMR), which is "a heliumcooled, graphite-moderated high temperature reactor being designed by the South African Utility ESKOM. Its elementary differences to existing reactors are the use of fuel pebbles (uranium particles encased in graphite) and the usage of helium gas as coolant in a closed cycle system."139

Turkey has begun work on a waste management system for radiological wastes. It has a facility for interim storage of these wastes. This storage facility, which compacts, cements, and precipitates the waste, has been in operation in Istanbul since 1989. Detailed regulations are yet to be drafted. ${ }^{140}$

\section{$\underline{\text { Regulation }}$}

The Turkish Atomic Energy Authority (TAEK) is the main regulatory organization for Turkey on nuclear safety. ${ }^{141}$ It reports to the Prime Minister. Its responsibilities include establishing national policy regarding nuclear energy as well as developing plans and programs; executing and supporting research, analysis, and studies on nuclear energy; establishing research and training centers, laboratories, test facilities, and pilot plants as needed; educating the personnel in the nuclear field and establishing cooperative projects with universities and other related organizations; giving approval,

\footnotetext{
${ }^{137}$ INFCIS, "Nuclear Fuel Cycle Information System, List of Nuclear Fuel Cycle Facilities: Turkey." International Atomic Energy Agency, 2003. Accessed 12 April 2007. http://www-nfcis.iaea.org/Default.asp

${ }^{138}$ Bowen, Wyn Q. and Joanna Kidd. "The Nuclear Capabilities and Ambitions of Iran's Neighbors", Getting Ready for a Nuclear-Ready Iran. Henri Sokolski and Patrick Clawson, ed. Strategic Studies Institute, October 2005. Accessed 12 April 2007. http://www.strategicstudiesinstitute.army.mil/pdffiles/pub629.pdf

${ }^{139}$ Gas Cooled Reactor Project Group, Hacettepe University. "The Pebble Bed Modular Reactor." Accessed 12 April 2007. http://www.nuke.hacettepe.edu.tr/pbmr/pbmrinfo.html

${ }^{140}$ IAEA Department of Nuclear Energy, "Country Nuclear Power Profiles: Turkey", last updated August 2005. Accessed 12 April 2007.

http://www.pub.iaea.org/MTCD/publications/PDF/cnpp2004/CNPP_Webpage/countryprofiles/Turkey/Tur key2004.htm

${ }^{141}$ Turkish Atomic Energy Authority, http://www.taek.gov.tr
} 
permission and license, related to the site selection, construction, operation of nuclear installations; public education on nuclear matters; and preparing and implementing the regulatory framework for nuclear and radiological safety. The CNRTC is a subdivision of the TAEK particularly devoted to research on nuclear reactor and fuel technology. TAEK was established by a government Act in 1982 and superseded the former organization, the Atomic Energy Commission. The Nuclear Safety Department (NGD) of TAEK is the responsible unit for evaluating licensing applications of nuclear installations within the Nuclear Power and Safety Division. ${ }^{142}$

TAEK has developed a thorough nuclear law and has issued an extensive list of nuclear regulations, including those governing physical protection of special nuclear material, radiation safety, seismic design of nuclear facilities, siting of nuclear power plants, quality assurance, safe transport of radioactive materials, and handling and storage of nuclear fuels. ${ }^{143}$

Turkey's Ministry of Energy and Natural Resources also monitors the development of nuclear energy. ${ }^{144}$

\section{Intentions}

Turkey's case for pursuing nuclear energy use if based on its nuclear research, regulation and development, its high percentage of imported energy, and its significant annual growth rate of energy demand, Turkey's population growth rate is $1.06 \%$, which slightly greater than that of the US at $0.91 \%,{ }^{145}$ but the industrializing nation has an increasing electricity demand that grew at a rate of about $8.4 \%$ per year from 1975 to $2000 .{ }^{146}$ This rate of demand increase is expected through 2010. ${ }^{147}$ A significant portion of Turkey's total export income is devoted to obtaining energy, as the country imports approximately $50-60 \%$ of its fuel, primarily in the form of crude oil and natural gas. ${ }^{148}$ This percentage is projected to rise to $73 \%$ in 2010 and further to $78 \%$ in $2020 .{ }^{149}$ Some time ago, the World Bank asserted that "Turkey's domestic production of oil and gas is

\footnotetext{
${ }^{142}$ Nuclear Energy Authority. “Country Profiles: Turkey.” Last updated 1 March 2007. Accessed 12 April 2007. http://www.nea.fr/html/general/profiles/turkey.html\#nppstatus

${ }^{143}$ IAEA Department of Nuclear Energy, "Country Nuclear Power Profiles: Turkey”, last updated August 2005. Accessed 11 April 2007.

http://www.pub.iaea.org/MTCD/publications/PDF/cnpp2004/CNPP_Webpage/countryprofiles/Turkey/Tur key2004.htm

${ }^{144}$ Ministry of Energy and Natural Resources, http://www.enerji.gov.tr/

${ }^{145}$ Central Intelligence Agency. "Turkey," The World Factbook. Last updated 15 March 2007. Accessed 11 April 2007. https://www.cia.gov/library/publications/the-world-factbook/geos/tu.html

${ }^{146}$ RPC Department, Turkish Electricity Transmission Co. "Annual Development of Turkey's Gross Generation-Imports-Exports and Demand," Electricity Generation - Transmission Statistics of Turkey. Accessed 13 April 2007. http://www.teias.gov.tr/istatistik2005/28.xls

${ }^{147}$ Birol, Dr. Erdener. "National Energy Outlook of Turkey and Expectations from Nuclear Technology," World Nuclear Association Annual Symposium, London: 4-6 September 2002. Accessed 12 April 2007. http://www.world-nuclear.org/sym/2002/pdf/birol.pdf

${ }^{148}$ Ibid; World Energy Council. "Pricing in Developing Countries - The Case of Turkey: Conserving to Grow, Energy Sector," 2007. Accessed 12 April 2007. http://www.worldenergy.org/wecgeis/publications/reports/pedc/cases/turkey.asp

${ }_{149}$ Kiliç, A.M. "Turkey's natural gas necessity, consumption and future perspectives," Energy Policy, Vol 34, No.14, September 2006. 1928-34.
} 
insufficient to meet its fast growing demand. As a result, its dependence on imported energy, especially oil and gas, has increased significantly over the last two decades."

In fact, in 1992, the Ministry of Energy and Natural Resources stated in a report that the country would face an energy crisis if the country fails to install new energy resources before 2010, suggesting that nuclear energy generation should be considered as a near-term option. The High Council of Science and Technology identified nuclear electricity generation as the third highest priority project of the country a year later. ${ }^{151}$ More recently, in 2004, the Turkish Minister of Energy and Natural Resources Hilmi Guler said Turkey should be producing 4,500 MW of nuclear power by 2012. The Ministry believes Turkey is one of the few developing countries that possesses the infrastructure to transfer and to develop nuclear technology. Turkey has announced plans to start construction on a nuclear power plant in $2007 .{ }^{152}$

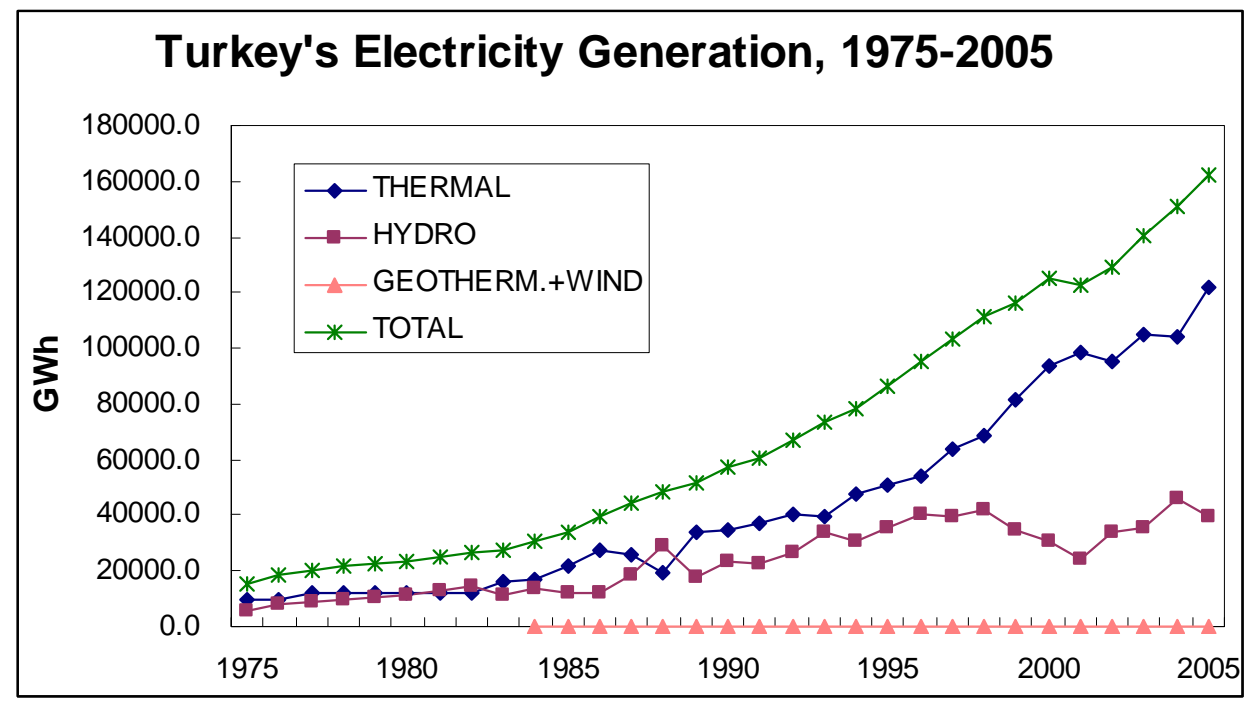

Figure 1. Electricity Generation by Source, $1975-2005 .{ }^{153}$

Turkey's energy policies aim towards the promotion of the economic development and welfare of the country. They can be summarized briefly in five groups according to their priorities:

1. Liberalization of the sector, increased overall productivity and efficiency, and enhanced transparency in the sector by the creation of a competitive environment in the energy market;

\footnotetext{
${ }^{150}$ Pakulski, Jan. "World Bank Helps Turkey Assess Feasibility of Baku-Ceyhan Oil Export Pipeline Route,” World Bank Intranet, News Release 97/1117 ECA. 12 September 1996. http://web.worldbank.org/ ${ }^{151}$ IAEA Department of Nuclear Energy, "Country Nuclear Power Profiles: Turkey", last updated August 2005. Accessed 11 April 2007. http://wwwpub.iaea.org/MTCD/publications/PDF/cnpp2004/CNPP_Webpage/countryprofiles/Turkey/Turkey2004.htm

${ }^{152}$ Broad, William J. and David E. Sanger. "With Eye on Iran, Rivals Also Want Nuclear Power," The New York Times, 15 April 2007.

${ }^{153}$ RPC Department, Turkish Electricity Transmission Co. "Annual Development of Turkey's Gross Generation-Imports-Exports and Demand (1975-2005)," Electricity Generation - Transmission Statistics of Turkey 2005. Accessed 13 April 2007. http://www.teias.gov.tr/istatistik2005/28.xls
} 
2. Transportation of hydrocarbon resources from countries in the East to developed markets in the West through the "East-West Energy Corridor" through Turkey;

3. Resource diversification for energy security in Turkey in order to address increasing demand and import dependency;

4. Targeting sustainable development in evaluation and consumption of energy resources, taking into consideration the environmental issues as well; and

5. Intensifying R\&D studies and activities on new energy technologies, including nuclear energy. ${ }^{154,155}$

The policy's focus on resource diversification, environmental concerns and sustainable development, and research for new energy technologies promote the option of nuclear energy as an integral part of Turkey's energy future.

In the interim, as Turkey works to fund and construct nuclear power facilities, the country seeks to develop renewable energy resources and to increase the efficiency of its current energy use. Turkey already uses hydropower as a primary energy source for electricity generation. Trends towards market liberalization, targeted investments, and regulation by the National Energy Conservation Centre (NECC) have tended to improve the overall economic efficiency in Turkey, ${ }^{156}$ and according to Turkey's energy policy Five-Year Development Plans, 'energy conservation' is one of its basic principles. ${ }^{157}$

Turkey's public commitment to nonproliferation enhances the likelihood that it is a likely candidate for peaceful uses of nuclear energy without increasing proliferation risk. News media reported that, in November 2004, Turkish Foreign Minister Abdullah Gul told journalists Turkey wanted the Middle East to be a region free of nuclear weapons. Moreover, some experts argue that,

"There is no evidence in available open sources that suggests Turkey has a nuclear weapons program. Indeed, given the openness of Turkey's nuclear research program, small uranium reserves, and lack of enrichment and reprocessing capabilities, it is difficult to believe that Ankara could develop a weapons program in the near future."

\footnotetext{
${ }^{154}$ Nuclear Energy Authority. “Country Profiles: Turkey.” Last updated 1 March 2007. Accessed 12 April 2007. http://www.nea.fr/html/general/profiles/turkey.html\#nppstatus

${ }^{155}$ IAEA Department of Nuclear Energy, "Country Nuclear Power Profiles: Turkey", last updated August 2005. Accessed 5 April 2007.

http://www.pub.iaea.org/MTCD/publications/PDF/cnpp2004/CNPP_Webpage/countryprofiles/Turkey/Tur key2004.htm

${ }^{156}$ World Energy Council. "Pricing in Developing Countries - The Case of Turkey: Conserving to Grow, Energy Sector," 2007. Accessed 12 April 2007. http://www.worldenergy.org/wec-

geis/publications/reports/pedc/cases/turkey.asp

${ }^{157}$ Birol, Dr. Erdener. "National Energy Outlook of Turkey and Expectations from Nuclear Technology," World Nuclear Association Annual Symposium, London: 4-6 September 2002. Accessed 12 April 2007. http://www.world-nuclear.org/sym/2002/pdf/birol.pdf

${ }^{158}$ Bowen, Wyn Q. and Joanna Kidd. "The Nuclear Capabilities and Ambitions of Iran's Neighbors", Getting Ready for a Nuclear-Ready Iran. Henri Sokolski and Patrick Clawson, ed. Strategic Studies Institute, October 2005. Accessed 12 April 2007.
} 
Some allegations of potential proliferation threat have been made, chiefly by Greece, though predating the current détente between the countries. Greece alleged Turkey was taking up an offer by Pakistan to cooperate on a weapons program. Turkey has clearly denied these allegations. ${ }^{159}$

Dr. Ian Lesser of the Woodrow Wilson International Center for Scholars considers Turkey as "among the countries most exposed to proliferation developments in the Middle East." Iran's development of a nuclear program poses direct risks to Turkey, as the countries share a border, and has instigated some concern. Lesser considers the main perceived threat to be a by-product of American and Israeli confrontation with Iran, noting that, "Turkish observers find it difficult to imagine circumstances under which Iran or Iraq would employ such weapons against Turkey - except in retaliation for American intervention launched from Turkish bases." Consequently, assurance of Western support is crucial to Turkey's perception of security. In the past, Turkey has been disappointed with the "slow and contentious" NATO response to Turkish requests for air defense reinforcements, such as in the Gulf War and prior to the 2003 Iraq invasion. Turkey's close ties with NATO and the European Union require the reliability of these countries' commitment to Turkish defense, particularly with respect to threats from Iraq, Iran, and Syria; but granting that, Turkey likely will not perceive the need to develop nuclear weapons as part of its security strategy. ${ }^{160}$ (Lesser 2005)

\section{ECONOMIC}

\section{Electricity}

Turkey produces 143 billion $\mathrm{kWh}$ annually of electricity, and consumes 140.3 billion $\mathrm{kWh}$. It exports 1.1 billion $\mathrm{kWh}$, and imports half that amount. ${ }^{161}$ Turkey has sought to diversify its energy resources by developing hydropower, which now constitutes approximately $26 \%$ of Turkey's total electricity generation. ${ }^{162}$

Turkey's electric grid is connected with the European electricity grid (UTCE system) via Bulgaria, and to the Mashreq Arab countries via a connection with Syria. See Figure 2 for a visual perspective on the interconnections among Middle Eastern and North African countries' grid systems.

\footnotetext{
${ }^{159}$ Lesser, Ian. “Turkey, Iran, and Nuclear Risks," Getting Ready for a Nuclear-Ready Iran. Henri Sokolski and Patrick Clawson, ed. Strategic Studies Institute, October 2005. Accessed 13 April 2007. http://www.strategicstudiesinstitute.army.mil/pdffiles/pub629.pdf

${ }^{160}$ Ibid.

${ }^{161}$ Central Intelligence Agency. "Turkey," The World Factbook. Last updated 15 March 2007. Accessed 11 April 2007. https://www.cia.gov/library/publications/the-world-factbook/geos/tu.html

${ }^{162}$ Nuclear Energy Authority. "Country Profiles: Turkey." Last updated 1 March 2007. Accessed 12 April 2007. http://www.nea.fr/html/general/profiles/turkey.html\#nppstatus
} 
Note: Spain and Turkey (via Bulgaria) are connected to the European UTCE system

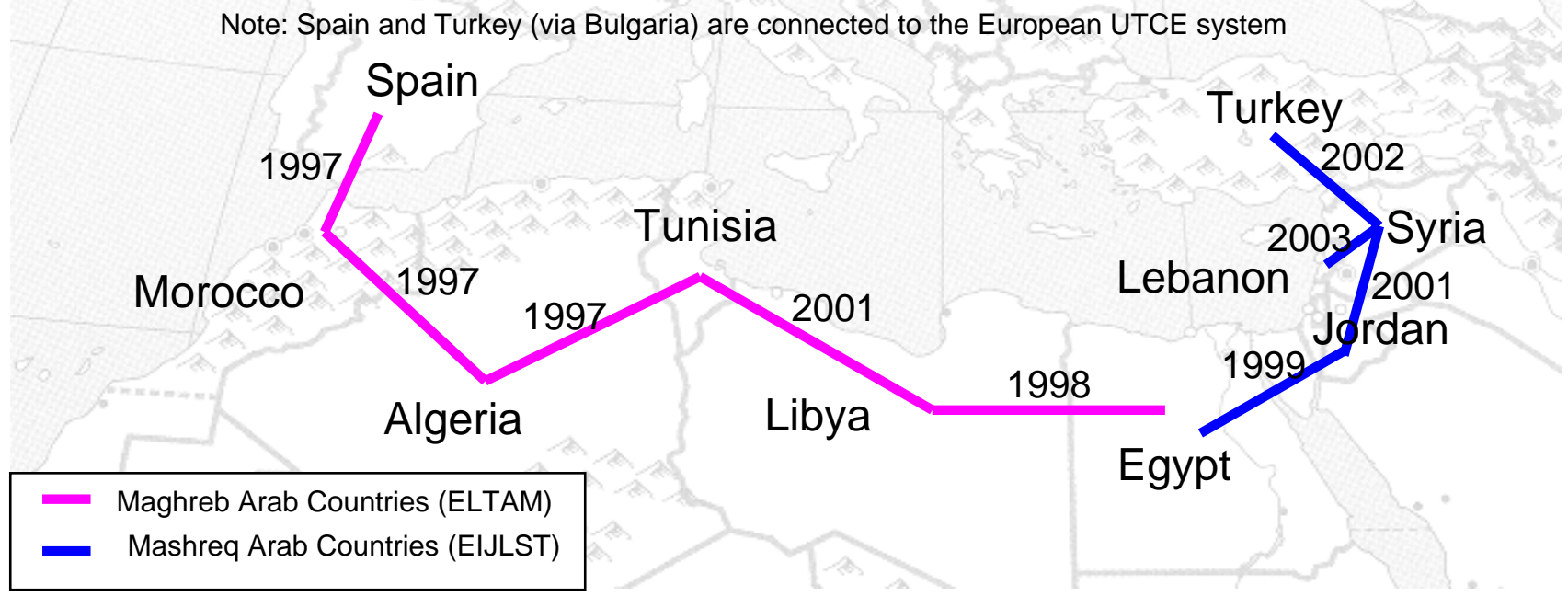

Figure 2. Interconnection of Electric Grids in the Middle East and North Africa. ${ }^{164}$

Oil

Turkey has low oil production of 50,000 bbl per day, considering that Turkish consumers use $715,100 \mathrm{bbl}$ per day. The country exports $46,110 \mathrm{bbl}$ per day, and imports 616,500 bbl per day. ${ }^{165}$ The cost of these imports amounts to approximately $7 \%$ GNP, and "every dollar increase in the average annual oil price increases Turkey's annual oil import bill by around US $\$ 150$ million." "166 Turkey’s proved reserves contain more than 288 million bbl of oil.

Turkey's geographical location is strategic in terms of energy resources, because it transmits important oil and gas resources from Central Asia to Europe and the West. Oil began to flow through the Baku-Tblisi-Ceyhan pipeline in May 2006, marking a major milestone that will bring up to 1 billion barrels per day from the Caspian to market. ${ }^{167}$

The World Bank notes that Turkey's oil imports and revenues suffered as a result of the Iraq embargo and the war:

"One of Turkey's main sources of crude oil was from Iraq through the IraqTurkey crude oil pipeline first constructed in 1976 and later expanded to carry about $73 \mathrm{mt}$ of Iraqi crude oil for export through the port of Ceyhan. The pipeline's operations were suspended in August 1990 under the United Nations' embargo on Iraq. Subsequently, Turkey not only lost revenue earned from the

163 “The Potential for Regionally Integrated Energy Development in Africa”, World Energy Council 2007. Accessed 21 May 2007.

http://www.worldenergy.org/wec-geis/publications/reports/africa/cooperation/cooperation.asp

164 "The Potential for Regionally Integrated Energy Development in Africa", World Energy Council 2007.

Accessed 21 May 2007.

http://www.worldenergy.org/wec-geis/publications/reports/africa/cooperation/cooperation.asp

${ }^{165}$ Central Intelligence Agency. "Turkey," The World Factbook. Last updated 15 March 2007. Accessed 11 April 2007. https://www.cia.gov/library/publications/the-world-factbook/geos/tu.html

${ }^{166}$ Donnelly, Roger. “Trip Report: Sri Lanka \& Turkey,” Export Finance and Insurance Corporation, Market Watch, 29 September 2006. Accessed 18 April 2007. http://www.efic.gov.au/

${ }^{167}$ Central Intelligence Agency. "Turkey," The World Factbook. Last updated 15 March 2007. Accessed 11 April 2007. https://www.cia.gov/library/publications/the-world-factbook/geos/tu.html 
transportation of Iraq's crude oil for export, but also lost a secured source for its own requirements." 168

Consequently, Turkey has since pursued importing oil from alternative sources, as well as other ways to supply its growing energy needs.

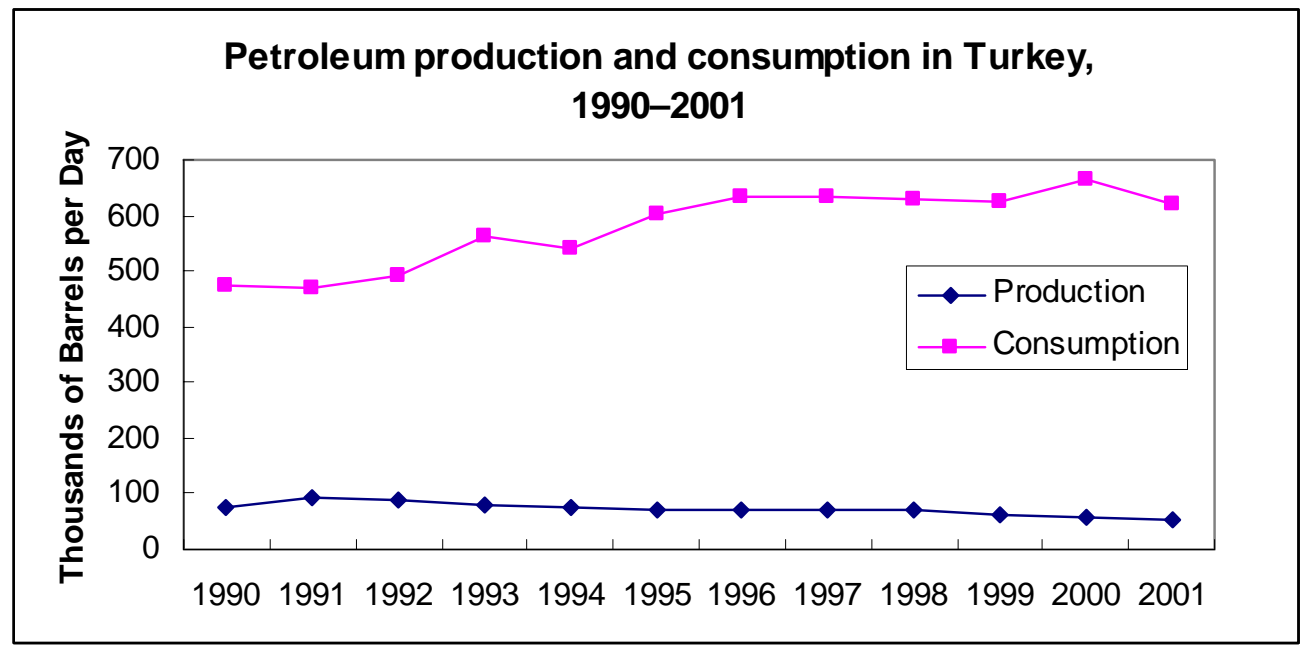

Figure 3. Oil consumption growth in Turkey, 1990-2001. ${ }^{169}$

\section{Natural Gas}

Turkey produces 688 million cu m annually, and does not export any natural gas. It consumes 22.6 billion cu m, of which 21.7 billion cu $\mathrm{m}$ is imported from Azerbaijan, Turkmenistan, Russia, Algeria, and Nigeria. Turkey has proven reserves of 8.5 billion cu m. ${ }^{170}$ Turkey is also a main transit state for both oil and natural gas between oil-rich nations around the Black and Caspian Seas and Western nations, and plans are underway for increasing its role in fuel transport. Nuclear energy could significantly alleviate Turkey's dependence on imported natural gas and oil resources and provide a more environmentally-friendly option suitable for sustainable development.

\section{INTERNATIONAL TREATY AND AGREEMENT COMMITMENTS}

\section{IAEA Membership and International Treaty Commitments}

Turkey joined the IAEA in 1957. In November 2006, Director General Mohamed ElBaradei commended Turkey as a "solid IAEA partner," reliable in its support for

\footnotetext{
${ }^{168}$ Pakulski, Jan. "World Bank Helps Turkey Assess Feasibility of Baku-Ceyhan Oil Export Pipeline Route,” World Bank Intranet, News Release 97/1117 ECA. 12 September 1996. http://web.worldbank.org/ 169 Tunç, Murat, Ünal Çamdali, and Cem Parmaksizoğlu. "Comparison of Turkey's electrical energy consumption and production with some European countries and optimization of future electrical power supply investments in Turkey," Energy Policy, Vol 31 Issue 1, January 2006. p. 50-9.

${ }^{170}$ Central Intelligence Agency. "Turkey," The World Factbook. Last updated 15 March 2007. Accessed 11 April 2007. https:/www.cia.gov/library/publications/the-world-factbook/geos/tu.html
} 
Technical Cooperation programs and in paying contributions. ${ }^{171}$ Turkey has been a member of the International Project on Innovative Nuclear Reactors and Fuel Cycles (INPRO) since 2001, contributing both financially and with participation in research. Turkey established a Safeguards Agreement in 1981 and an Additional Protocol on 17 July $2001,{ }^{172}$ and it signed and ratified the Convention on Nuclear Safety by $1995 .{ }^{173}$

Turkey signed the Limited (Partial) Test Ban treaty on 9 August 63 and ratified it two years later. ${ }^{174}$ Turkey signed the Comprehensive Test Ban Treaty and ratified it in February 2000. ${ }^{175}$

For an extensive list of Turkey's bilateral and multilateral agreements, as well as agreements signed with the IAEA, see Appendix D.

Though Turkey has strong domestic regulatory agencies, its legal framework for establishing nuclear safety and security remains lacking. Though it is an active participant in the IAEA community, it has yet to join important agreements on spent fuel and radioactive waste management and export controls. Regarding IAEA objectives for establishing a regulatory framework for nuclear purposes, IAEA Director General noted that, for Turkey, "Additional milestones to be achieved include: radiological protection of medical patients; environment and waste issues; and emergency preparedness." ${ }^{, 176}$ For a full list of Turkey's multilateral convention and safeguards agreements with the IAEA, see Appendix E.

\section{IAEA Technical Cooperation Projects}

Turkey is involved in seven national Technical Cooperation projects, twenty regional projects, and two interregional projects. These have included projects related to improving the existing nuclear fuel development capability, human resource development and nuclear technology support, management of radioactive waste, peparedness and response for nuclear emergencies, upgrading nuclear security-related national infrastructure, safety review of research reactor facilities, and a number of projects in nuclear medicine, agriculture, and farming techniques. ${ }^{177}$

\footnotetext{
${ }^{171}$ ElBaradei, Dr. Mohamed. "Nuclear Power: A Changing Landscape," Statements of the Director General, 7 July 2006. Accessed 13 April 2007. http://inis-a4.iaea.org/fulltext/p/37/118/37118679.pdf

${ }^{172}$ International Atomic Energy Association. "Strengthened Safeguards System: Status of Additional Protocols," 22 March 2007. Accessed 10 April 2007. http://www.iaea.org/OurWork/SV/Safeguards/sg_protocol.html

${ }^{173}$ International Atomic Energy Association. "Convention on Nuclear Energy," 11 May 2006. Accessed 11 April 2007. http://ola.iaea.org/OLA/treaties/multi.asp

${ }^{174}$ Bureau of Verification, Compliance, and Implementation, U.S. Department of State. "Treaty Banning Nuclear Weapon Tests in the Atmosphere, in Outer Space, and Under Water." Accessed 9 April 2007. http://www.state.gov/t/ac/trt/4797.htm\#signatory

175 "Turkey: Statement by Ambassador Kurtulus Taskent at the Second Conference on Facilitating the Entry Into Force of the Comprehensive Nuclear Test Ban Treaty," New York, 12 November 2001. Accessed 11 April 2007. http://www.un.org/webcast/ctbt/statements/turkeyE.htm

${ }^{176}$ ElBaradei, Dr. Mohamed. "Nuclear Power: A Changing Landscape," Statements of the Director General, 7 July 2006. Accessed 13 April 2007. http://inis-a4.iaea.org/fulltext/p/37/118/37118679.pdf ${ }^{177}$ International Atomic Energy Agency, "Information Records on Turkey." Accessed 5 April 2007. http://www-tc.iaea.org/tcweb/regionalsites/europe/country/default.asp?cid=TUR
} 
Turkey has also been participating in the "Technical Working Group on Gas Cooled Reactors" coordinated by the IAEA. ${ }^{178}$

\section{REGIONAL PROJECT POSSIBILITIES}

Turkey's government faces complex foreign policy challenges that could affect its ability to conduct regional projects on nuclear energy. Its geographic location has caused some ambiguity regarding whether it is European, Middle Eastern, and/or Eurasian, and therefore who its most natural collaboration partners ought to be. Turkey has close political and economic relations with the European Union, but the European Union (EU) has been slow to admit Turkey as a member because of domestic reforms deemed necessary for accession, such as economic growth and reform, and concerns regarding human rights. On the other hand, Turkey may be beginning to see the stringent conditions for EU membership as perhaps too demanding. ${ }^{179}$ A particular controversy with Greece that has hindered Turkey's accession to the EU concerns the state of Cyprus; but currently Turkey and Greece are in a period of rapprochement, with close enough ties such that, "Despite the disagreement on the Cyprus issue, Turkey has already started negotiations for trade in electricity with Greece. Turkey is preparing to export electricity to some Greek islands." $" 180$

Turkey must carefully balance its international relations between Europe and the Middle East, as it seeks to be included in Europe's affluence and stability, yet at the same time to maintain possible ties for future economic resources from the Middle East. Turkey's relations with its Arab neighbors for the latter half of the twentieth century were characterized by "severe tensions and continual mutual estrangement" "181 and "mutual diffidence and mistrust" ${ }^{182}$ as a result of the legacy of the Ottoman Empire, the TurkishIsraeli alliance, and differing policies during the Cold War. Turkey has had particularly tense relations with Syria, resulting from water disputes concerning the Euphrates River and probable Syrian sanctuary of and assistance for the Kurdish separatist armed movement, the PKK. ${ }^{183}$ However, recent efforts have been made to significantly improve foreign relations with Arab nations. In 2003 the Former Turkish Prime Minister Abdullah Gul toured Arab capitals, in the most comprehensive visit since the establishment of the Turkish state, symbolizing improved international relations. Currently Turkey seeks to strengthen economic ties with Arab countries. It has also been

\footnotetext{
${ }^{178}$ Nuclear Energy Authority. “Country Profiles: Turkey.” Last updated 1 March 2007. Accessed 12 April 2007. http://www.nea.fr/html/general/profiles/turkey.html\#nppstatus

${ }^{179}$ Foreign Policy Insitute, "Year-End Thoughts on Turkey's Foreign Policy Issues," 2 January 2006. Accessed 18 April 2007. http://www.foreignpolicy.org.tr/documents/seyfitashan_020106_2.htm

${ }^{180}$ Gursoy, Begum. “Turkey to light Greek Aegean Islands,” Dogan Daily News, Inc., 17 November 2006. Accessed 17 April 2007. http://www.turkey-now.org/Default.aspx?pgID=677\&langid=1

${ }^{181}$ Allah, Samir Atta. “The New Turkish Visitor,” World Press Review, Vol. 50 No. 3, March 2003. Accessed 18 April 2007. http://www.worldpress.org/Mideast/959.cfm

${ }^{182}$ Lesser, Ian. "Turkey, Iran, and Nuclear Risks," Getting Ready for a Nuclear-Ready Iran. Henri Sokolski and Patrick Clawson, ed. Strategic Studies Institute, October 2005. Accessed 12 April 2007. http://www.strategicstudiesinstitute.army.mil/pdffiles/pub629.pdf

${ }^{183}$ Sezer, Duygu Bazoglu. "Turkey's Political and Security Interests and Policies in the New Geostrategic Environment of the Expanded Middle East," The Henry L. Stimson Center, Occasional Paper No. 19, July 1994. Accessed 18 April 2007. http://www.stimson.org/pdf/OccasionalPaper19.pdf
} 
suggested that Turkey can provide a model for other predominantly Muslim nations in the Middle East in the areas of strengthened economy, democratization, and political secularization without loss of religious identity. ${ }^{184}$ Saudi Arabia's Ambassador to Turkey, Dr. Mohammed R. Al-Hussaini, told Turkish media that Saudi Arabia considers Turkey's membership to the EU as strategically important. The Ambassador argued that the Middle East needs Turkish-Saudi Arabian partnership in many issues, and said, "Turkey will be a bridge between the Arab world and the West." 185

Turkey has especially close relations with Israel, as both are non-Arab, democratic states with Western-oriented public policy and important allied relationships with the United States. Turkey was the first majority-Muslim nation to recognize the State of Israel, and ever since they have shared close economic ties and cooperated in defense. Turkey has much to offer its neighbors in terms of technical expertise and framework for establishing a nuclear energy program, but it lacks the funding required for doing so. Partnering with Middle East or European nations to build a power plant and to export a portion of electricity generated would allow Turkey to pursue its energy goals for the near future. In particular, Turkey could utilize the connection of its electricity grid to that of Egypt and Jordan to easily transport nuclear-generated electricity to these nations. Turkey could also become a base for research and development (R\&D) efforts for the Gulf Cooperation Council nations, who have recently declared their interest in nuclear energy. The GCC has more available funds from oil exports but a limited technological capacity, so such a partnership could be mutually beneficial. United States support of Turkish nuclear energy plans could be mutually valuable to aid the Turkish energy condition and to improve U.S.-Turkey relations.

\footnotetext{
${ }^{184}$ Hermann, Rainer. “Turkey as Model for the Middle East?” Qantara, 2006. Accessed 15 June 2007. http://www.qantara.de/webcom/show_article.php/_c-476/_nr-681/i.html

${ }^{185}$ Tascan, Gulcan. "Turkey’s EU Membership is Strategically Important for Arab World," Turkish Weekly, 19 August 2006. Accessed 15 June 2007. http://www.turkishweekly.net/news.php?id=36926
} 


\section{MOROCCO}

Overview

The first country to seek diplomatic relations with the United States Government in 1777, Morocco remains "one of our oldest and closest allies" in the Middle East and North Africa. ${ }^{186}$ The country is strategically located in northwestern Africa on the southern side of the Strait of Gibraltar. Slightly larger than the state of California, Morocco ranks $56^{\text {th }}$ in the world by size. Its population is 33.7 million, $36^{\text {th }}$ in the world, of whom almost all are Arab-Barbar by ethnicity and $98.7 \%$ of the population is Muslim. Low economic growth, a high poverty rate, and an infant mortality rate six times that of the U.S. have contributed to Morocco's slow development. Morocco also faces environmental burdens of earthquakes, droughts, land desertification, and polluted water.

Morocco's unpredictable economy is heavily dependent upon its strongest economic sector, agriculture. As almost 50\% of Morocco's population depends directly on agriculture, droughts have a severe negative effect on the economy. GDP growth rate has fluctuated significantly in the past several years, due to changing weather patterns and hence crop yields, ranging from $0.97 \%$ in 2000 to $6.7 \%$ in 2006 . On the other hand, significant economic reforms have increased the infrastructure of the economy and decreased the rate of inflation, particularly since the 1980's. Nominal GDP per capita has risen to $\$ 4,400$, up from $\$ 1,677$ in 2004; however, Morocco still ranks $141^{\text {st }}$ in the world in this respect, and its GDP per capita is still less than half the world average of $\$ 10,000$. The labor force consists of 11.25 million people, with an overall unemployment rate of $7.7 \%$, but this masks a rate as high as $20 \%$ in urban areas. In terms of energy, Morocco has a very low consumption rate of electricity per capita at $560 \mathrm{kWh}$ per annum, compared to $12,454 \mathrm{kWh}$ in the US or $2,962 \mathrm{kWh}$ for the world average. In 2004, Morocco signed a free trade agreement with the United States in order to promote foreign direct investment and trade; the agreement took effect January 2006. Morocco's government seeks to reduce poverty and to provide more jobs in order to promote domestic security and development; it also is working to improve education and to raise living standards. Morocco's military expenditures are high by world terms, ranking $19^{\text {th }}$ as a percentage of GDP at 5\%, but its ranking is significantly lower than many other Middle East and North African countries. ${ }^{187}$ (CIA Factbook 2007, U.S. Department of State 2006)

Because Morocco imports almost all of its primary energy resources, the country is actively pursuing alternative sources of energy. The expansion of Morocco's electricity grid to rural areas of the country has also increased the strain on domestic electricity generation. The country has shown interest in nuclear power and nuclear desalination for decades, but lacks finances and infrastructure necessary to develop it. The nuclear research reactor currently under construction can be a significant step in Morocco's preparation for nuclear energy, and further collaboration with international allies such as the United States, France, and Egypt in nuclear energy.

\footnotetext{
${ }^{186}$ Bureau of Near Eastern Affairs. "Background Note: Morocco," U.S. Department of State, February 2007. Accessed 24 April 2007. http://www.state.gov/r/pa/ei/bgn/5431.htm\#econ

${ }^{187}$ Central Intelligence Agency. "Morocco," The World Factbook. Last updated 17 April, 2007. Accessed 19 April 2007. https://www.cia.gov/library/publications/the-world-factbook/geos/mo.html
} 


\title{
1. NUCLEAR INFRASTRUCTURE/INTENTIONS
}

\author{
Infrastructure
}

Knowledge management

Fifteen percent of Morocco's labor force works in industry, and their annual industrial production growth rate is $4 \%$. Morocco has a low literacy rate of $51.7 \%$ for total population; there is a significant discrepancy between the male and female literacy rates (64.1\% and 39.4\%, respectively). ${ }^{188}$ Morocco has established research centers, nuclear engineering associations, and a public policy evident of strong interest in nuclear energy, but it is still in the early stages of developing the knowledge base needed for a nuclear energy program.

The following universities participate in nuclear education and research:

- The Mohammed School of Engineers of University Mohammed V in Rabat partners with CNESTEN on Reactor Technology projects. ${ }^{189}$

- Some nuclear physics is taught at the University Mohammed $1^{\text {st }}$ in Oujda, under their Faculty of Sciences. ${ }^{190}$

- The Faculty of Science of University Ibn Zohr, Agadir, conducts alternative energy and groundwater research with potential relevance to nuclear energy. ${ }^{191}$

The principal public director of nuclear research in Morocco is the National Center of Energy, Sciences, and Nuclear Technology (CNESTEN) in Rabat. Its laboratories have been in operation since 2003, and the main areas of research conducted at the Center include nuclear medicine, life sciences, natural resources and the environment, nuclear energy and reactor technology, and radiation safety and radioactive waste management. Its goals are to promote nuclear science research and applications of nuclear science technology; to prepare the necessary technological base for the introduction of nuclear power, such as reactor technology and nuclear safety; and "to constitute the technical tool of the State regarding radiological safety." 192 In order to accomplish these missions, CNESTEN founded the Center for Nuclear Studies in Maâmora, the first nuclear studies center in Morocco, in partnership with France. ${ }^{193}$ Publicly owned with legal and financial autonomy, CNESTEN is under the supervision

\footnotetext{
${ }^{188}$ Central Intelligence Agency. "Morocco," The World Factbook. Last updated 15 March 2007. Accessed 11 April 2007. https://www.cia.gov/library/publications/the-world-factbook/geos/mo.html ${ }^{189}$ Recherche et Coopération, Ecole Mohammedia D’Ingénieurs, Université Mohammed V, http://www.emi.ac.ma/recherche/ (French)

${ }^{190}$ Faculté Sciences Oujda, Université Mohammed Premier. http://sciences1.univ-oujda.ac.ma/ (French)

${ }^{191}$ Axes de Recherche, Université Ibn Zohr, http://www.univ-ibnzohr.ac.ma/index.php?id=46 (French)

192 CNESTEN, http://www.cnesten.org.ma/ (French)

${ }^{193}$ Infosdumaroc.com. "Maroc: Débat à Rabat sur l'énergie nucléaire, aujourd hui et demain," 25 November 2005. http://www.infosdumaroc.com/modules/news/articles-1281-debat-a-rabat-sur-1-039energie-nucleaire-aujourd-.html (French)
} 
of Morocco's Ministry for Higher Education, which conducts cost-benefit analyses for energy resources and aids in the formation of national energy policy. ${ }^{194}$

Moroccan nuclear organizations have recently hosted conferences on the development of nuclear energy. In November 2005, the Association of Engineers in Atomic Engineering of Morocco (AIGAM) organized a conference with representatives of the energy sectors in Morocco, USA, and France. The Atomic Energy Commission (CEA) of France and the American Nuclear Society worked with Moroccans in order to evaluate opportunities and perspectives on the nuclear energy option in Morocco, in light of the international knowledge base on nuclear energy and its economic, industrial, and environmental advantages. They also considered relations with the IAEA, the future of nuclear energy, and economic and environmental considerations, among other topics. ${ }^{195}$

Another conference was held 14-16 March 2007, hosted by the Moroccan Association for Nuclear Engineering and Reactor Technology (GMTR). Topics of the conference included reactor theory and concepts, physics and computational methods for advanced reactors, reactor core and lattice physics methods, criticality and safety analysis, fuel loading and design, radioactive waste management, reactor dosimetry and shielding, and nuclear desalination. The conference was intended to be a celebration of the first research reactor, a TRIGA Mark-II, currently in the stages of commissioning. ${ }^{196}$ It was attended by more than 150 specialists from the U.S., France, Austria, Hungary, Canada, Japan, Spain, India, Italy, Algeria, Libya, Russia, Pakistan, Switzerland, Romania, Lithuania, and Morocco. ${ }^{197}$

\section{Uranium Resources}

Morocco is one of the leading exporters of phosphates, with extensive phosphate deposits at Gantour, Khouribga, Meskala, and Oued Eddahab. Uranium can be extracted from phosphates using a technology first developed by the Atomic Energy Commission in the 1950s, in which solvent extraction is used to strip uranium from wet phosphoric acid. ${ }^{198}$ Some sources say Morocco has about two-thirds of the world's known supply of phosphate rock. ${ }^{199}$ More phosphate deposits are found in the disputed territory of Western Sahara.

\footnotetext{
${ }^{194}$ Ministre de l'Education Nationale, de l'Enseignement Supérieur, de la Formation des Cadres et de la Recherche Scientifique, http:/www.dfc.gov.ma/ (French)

${ }^{195}$ Infosdumaroc.com. "Maroc: Débat à Rabat sur l'énergie nucléaire, aujourd hui et demain," 25 November 2005. http://www.infosdumaroc.com/modules/news/articles-1281-debat-a-rabat-sur-1-039energie-nucleaire-aujourd-.html (French)

${ }^{196}$ Moroccan Association for Nuclear Engineering and Reactor Technology. "Phytra1." Accessed 20 April 2007. http://www.fst.ac.ma/gmtr/phytra1/phytra1.html

${ }^{197}$ People's Daily Online. “Morocco promotes peaceful use of nuclear technology,” 15 March 2007. Accessed 20 April 2007. http://english.people.com.cn/200703/15/eng20070315_357707.html

198 Talbot, Stephen. “Westinghouse backs King Hassan’s Desert War.” Multinational Monitor, Vol. 1 No. 10, November 1980. Accessed 23 April 2007. http://multinationalmonitor.org/hyper/issues/1980/11/talbot.html

199 "Morocco," Microsoft Encarta Online Encyclopedia 2007. Accessed 23 April 2007. http://encarta.msn.com
} 
Neither the IAEA's World Distribution of Uranium Deposits Database (UDEPO) nor Uranium 2005: Resources, Production, and Demand list any uranium resources in Morocco. ${ }^{200,201}$

\section{Nuclear Reactors and Fuel Facilities}

Morocco is in the process of commissioning its first nuclear research reactor. The MA-R1 is a light-water pool reactor, a TRIGA-Mark II, designed and manufactured by General Atomics of the U.S. This type of reactor uses uranium-zirconium-hydride (UZrH) fuel. It plans to produce $2 \mathrm{MW}$ of power, with provisions to be upgraded to 3 MW. Owned and operated by CNESTEN, it was designed for use by scientific institutions and universities for purposes such as graduate education, private commercial research, non-destructive testing, and isotope production. The reactor has a maximum thermal neutron flux of $4.4 \times 10^{13} \mathrm{n} / \mathrm{cm}^{2}-\mathrm{s} .{ }^{202}$ Construction of the TRIGA Mark II Reactor began in 1999, and its fabrication is nearly complete. As of May 2006, the cold commissioning was nearing completion. Planned delivery of low-enriched uranium fuel was scheduled for March 2006, and the hot commissioning was planned to occur in April $2006 .{ }^{203}$

Some reports have noted Moroccan collaboration with Russia for developing nuclear facilities. In September 2006, Russian President Vladimir Putin visited Rabat, and a spokesman for Russia's nuclear export organization, Atomstroyexport, declared that Russia would bid on a contract to build Morocco's first nuclear power station. ${ }^{204}$ News media also reported that a Russian nuclear delegation, including representatives from Atomstroyexport, visited Morocco in March 2007, concerning building a nuclear power facility in the area of Sidi Boulbra, which is between Casablanca and Agadir, on the Atlantic. The site has been approved by the IAEA and it is projected that the plant will be built by 2013 , and on line by $2016 .{ }^{205,206,207}$

Morocco and China collaborated on a technical cooperation project under the IAEA in order to develop a pre-project study of a $10 \mathrm{MW}$ Nuclear Heating Reactor (NHR-10) for nuclear desalination to be built in Tan-Tan, Morocco. The plant was designed to have a production capacity of $8,000 \mathrm{~m}^{3} / \mathrm{d}$ of potable water through the multi-

\footnotetext{
${ }^{200}$ Integrated Nuclear Fuel Cycle Information Systems, World Distribution of Uranium Deposits Database. International Atomic Energy Agency. 2003. Accessed 24 April 2007. http://www-nfcis.iaea.org/

${ }^{201}$ Joint Report by the OECD Nuclear Energy Agency and the International Atomic Energy Agency. Uranium 2005:Resources, Production, and Demand, Paris: OECD Publishing, 2005. p. 215-9.

${ }^{202}$ Research Reactor Database. "Nuclear Research Reactors in the World: Egypt." International Atomic Energy Agency, 1999. Accessed 5 April 2007. http://www.iaea.org/worldatom/rrdb/

${ }^{203}$ European Nuclear Society, Research Reactor Fuel Management. " $10{ }^{\text {th }}$ International Topical Meeting: Transactions, Session 1," 30 April - 3 May 2006. Accessed 20 April 2007. http://www.euronuclear.org/meetings/rrfm2006/pdf/RRFM\%202006,Transactions,final,Session_1.pdf

${ }^{204}$ Salama, Sammy, and Heidi Weber. "The Emerging Arab Response to Iran's Unabated Nuclear Program," Center for Nonproliferation Studies, Monterey Institute for International Studies. 22 December 2006. Accessed 20 April 2007. http://www.nti.org/e_research/e3_83.html

${ }^{205}$ Kahina. "Le Maroc veut s'offrir une centrale nucéaire," Le Quotidien D’Oran, 25 March 2007. Accessed 20 April 2007. www.algerie-dz.com/article8890.html (French)

${ }^{206}$ Le Monde. "Moscou veut vendre une centrale nucéaire au Maroc," abstract. Article published 19 March 2007. Accessed 20 April 2007. lemonde.fr

${ }^{207}$ Salama, Sammy, and Heidi Weber. "The Emerging Arab Response to Iran's Unabated Nuclear Program," Center for Nonproliferation Studies, Monterey Institute for International Studies. 22 December 2006. Accessed 20 April 2007. http://www.nti.org/e_research/e3_83.html
} 
effect distillation (MED) process. This was a preliminary study, with results to be extrapolated for examining costs of a commercial nuclear desalination plant which would produce $140,000 \mathrm{~m}^{3} / \mathrm{d}$ of potable water using a $200 \mathrm{MW}$ NHR. The project was suspended in 2000, pending the results of another technical cooperation project with the IAEA using small and medium sized reactors for power production. ${ }^{208}$

Two nuclear fuel fabrication facilities were planned, but the IAEA cites their status as "deferred" as of 20 January 2000. Both facilities, one at Jorf Lasafar and the other at Safi, were commercial-scale laboratories designed for uranium recovery from phosphates. The Jorf Lasfar facility had a design capacity of 370 tons uranium per year, and was owned by France's CEA. The Groupe Office Cherifien des Phosphates owned the Safi plant, which had a design capacity of 470 tons uranium per year. No other facilities are known to have been developed for fuel fabrication in Morocco.

The Center for Nonproliferation Studies states that, "Morocco has not indicated any intention to develop enrichment or reprocessing facilities for enriching uranium or for the separation of plutonium." "209 Though these activities could have both civil and military applications, it is assumed that Morocco will import enriched fuel to supply any reactors, and return spent fuel to the supplier for reprocessing or other disposition.

\section{$\underline{\text { Regulation }}$}

Several regulatory agencies participate in the monitoring of nuclear material and the progress on nuclear energy. The National Council of Nuclear Energy assists the government in order to develop a national policy on the peaceful use of nuclear energy for technical and economical development. The National Center of Radiation Protection is in charge of the control, inspection and authorization of radioactive sources, and the Nuclear Safety Authority deals with nuclear installations. CNESTEN promotes the use of nuclear energy to help in setting up a nuclear power program and provides training in a variety of nuclear fields. CNESTEN also plans to commission a nuclear research center within a few years, which is expected to play a major role in training qualified personnel for nuclear energy management. ${ }^{210}$

\section{Intentions}

The Moroccan Minister of Energy and Mines, Mohammed Boutaleb, recently stated that Morocco encourages the use of nuclear technology for peaceful purposes. Speaking at a conference on Physics and Technology of Nuclear Reactors, he noted that nearly all of Morocco's energy needs are dependent on foreign imports, and he cited

\footnotetext{
${ }^{208}$ Megahed, Mohamed. "Nuclear desalination: history and prospects", International Journal of Nuclear Desalination, Vol. 135, 2001. pp. 169-185. Accessed 21 May 2007. http://www.desline.com/articoli/4047.pdf

${ }^{209}$ Salama, Sammy, and Heidi Weber. "The Emerging Arab Response to Iran's Unabated Nuclear Program," Center for Nonproliferation Studies, Monterey Institute for International Studies. 22 December 2006. Accessed 20 April 2007. http://www.nti.org/e_research/e3_83.html

${ }^{210}$ Tabet, Mohammed. "Prospects of Nuclear Desalination in Morocco," Int. J. Nuclear Desalination, Vol. 1 No. 4, 2005. Accessed 23 April 2007. http://www.inderscience.com/storage/f211934681271051.pdf
} 
reliable supply, generalized access to energy, and diversification of energy resources as primary goals of Morocco's national energy policy. ${ }^{211}$

The International Energy Agency confirms Morocco's high dependency on external energy supplies, calculating their dependence on imports for energy consumption at $97.9 \%$ for $2001 .{ }^{212}$ Electrical energy generation has not been able to keep up with an annual $8 \%$ increase in energy demand; consequently, Morocco has had to import electricity from Algeria and Spain. And despite extensive oil exploration efforts, Morocco has not uncovered any major oil resources and imports almost all its oil from the Persian Gulf and Russia. ${ }^{213}$

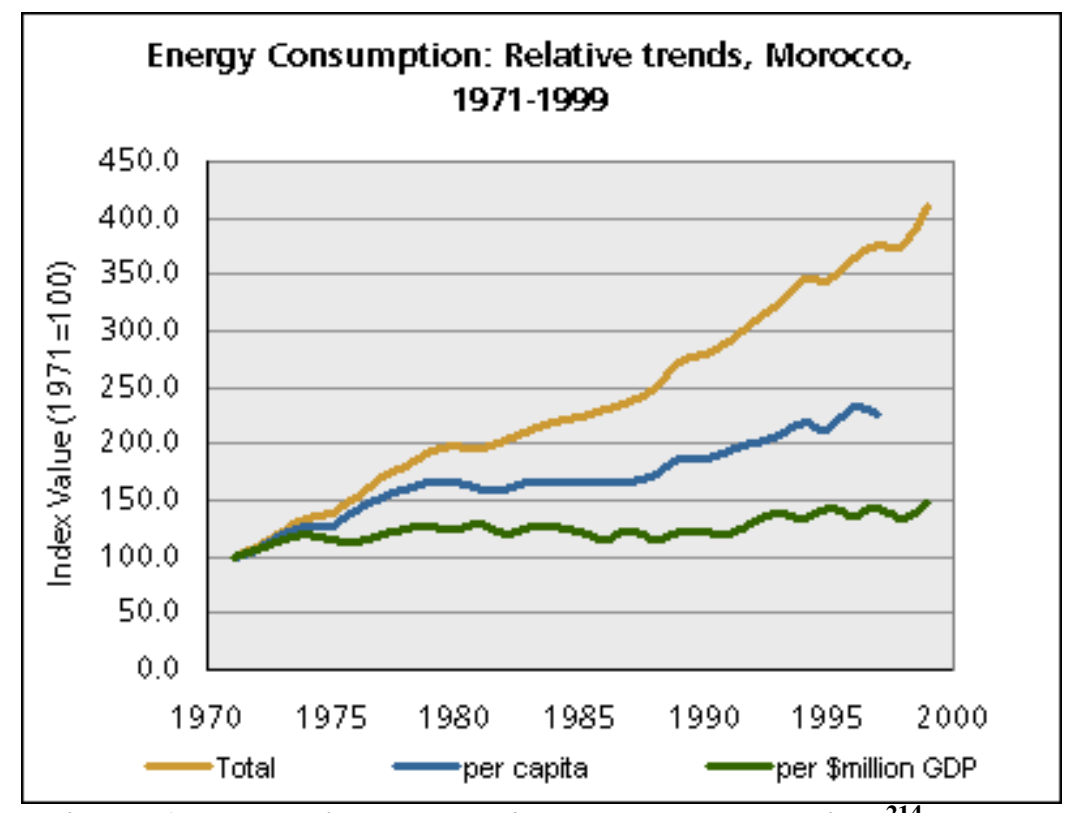

Figure 1. Trends in Morocco's energy consumption. ${ }^{21}$

Figure 2 shows the sources of primary energy supply by source. It should be noted that Morocco produces less than $0.2 \%$ of its oil consumption and has no domestic resources of coal.

\footnotetext{
${ }^{211}$ People's Daily Online. "Morocco promotes peaceful use of nuclear technology," 15 March 2007. Accessed 20 April 2007. http://english.people.com.cn/200703/15/eng20070315_357707.html ${ }^{212}$ International Atomic Energy Agency. "Kingdom of Morocco," Energy and Environment Data Reference Bank. Accessed 23 April 2007. http://www.iaea.org/inisnkm/nkm/aws/eedrb/

${ }^{213}$ Salama, Sammy, and Heidi Weber. "The Emerging Arab Response to Iran's Unabated Nuclear Program," Center for Nonproliferation Studies, Monterey Institute for International Studies. 22 December 2006. Accessed 20 April 2007. http://www.nti.org/e_research/e3_83.html

${ }^{214}$ EarthTrends: The Environmental Information Portal. "Energy and Resources, Country Profile Morocco," World Resources Institute, 2006. Accessed 23 April 2007. http://earthtrends.wri.org/
} 


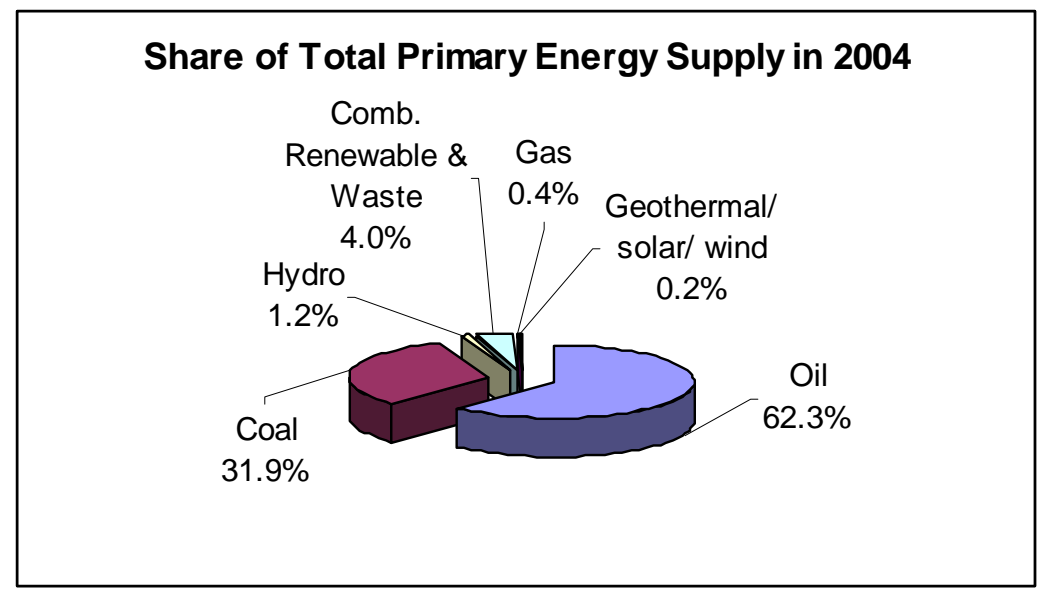

Figure 2. Primary sources for Morocco's energy supply. ${ }^{215}$

An international conference on "The Energy Challenges of the 21 st century for Morocco and for Europe" in January 2005 was organized by Morocco's Energy Federation of the General Confederation of Enterprises of Morocco (CGEM). In his opening statements, the President of CGEM expressed the country's desire to pursue the option of nuclear energy, in a statement worth quoting at length:

"In the long term (20 to 30 years), nuclear power seems to be a possible alternative, one desirable for our country. Indeed, nuclear power presents the advantage of providing electricity at a competitive price, without contributing to the greenhouse effect. Therefore, with this intention, two important parameters must be taken into account: the consequent investment, which must be authorized, and the inherent safety regarding the use of a nuclear reactor... While waiting for concretization of this research, for which we all hope, we must search for an alternative energy source other than fossil fuels, as I underlined, particularly taking into account the compound effects of the explosion of costs and the increase in our demand." 216

As Morocco expands its energy generation system to provide electricity to rural populations of the country, these energy needs will continue to increase, making another source of renewable energy an attractive option.

Because of Morocco's limited water resources, water desalination is another appealing application, in addition to electricity generation, of nuclear power capability. Morocco is particularly dependent upon reliable water resources because its economy is so heavily dependent on agriculture, and weather patterns resulting in dry seasons create especially adverse effects. Mohammed Tabet of Morocco's

\footnotetext{
${ }^{215}$ OECD/IEA. "Share of Total Primary Energy Supply in 2004: Morocco," IEA Energy Statistics, 2006. Accessed 23 April 2007. http://www.iea.org/Textbase/stats/index.asp

${ }^{216}$ Chami, Hassan. "Eléments d'intervention de M. Hassan Chami, Président de la CGEM," Le séminaire international sur "Les défis énergétiques du 21ème siècle pour le Maroc et pour l'Europe". La Fédération de l'énergie de la Confédération générale des entreprises du Maroc (CGEM): Rabat, 27 January 2005. Accessed 24 April 24, 2007. http://inis-a4.iaea.org/fulltext/p/37/121/37121733.pdf (French)
} 
CNESTEN, writing in the International Journal of Nuclear Desalination, summarizes the situation as follows:

"In the last few years, Morocco has experienced continuous dry seasons, which has put a great stress on its limited water resources. The availability of water has dropped from $3500 \mathrm{~m}^{3} / \mathrm{y} /$ capita in 1960 to 950 $\mathrm{m}^{3} / \mathrm{y} /$ capita presently [in 2005], and it is expected to decrease further to $490 \mathrm{~m} 3 / \mathrm{y} /$ capita by the year 2020. This means that according to the 'water stress index' (International Atomic Energy Agency, 2000), the country will be considered as one facing an absolute scarcity of fresh water." 217

Nuclear desalination could provide a consistent source of water to agriculturedependent areas of the country during droughts and dry weather (See Appendix Q).

Morocco has initiated negotiations concerning the construction of a nuclear power facility in the country since 1986, but a plan has not yet developed to the degree needed to support the introduction of nuclear energy. ${ }^{218}$ In the early 1980's, a feasibility study was launched concerning the introduction of a nuclear power plant into the national electric grid. Though nuclear power was found to be a viable option, the study concluded that the large commercial reactors could not be integrated into the limited electrical grid until 2015. Presently, the feasibility study is being updated with information for small to medium-sized reactors with the help of the IAEA. ${ }^{219}$ Tabet notes three areas for which the country requires significant progress in order to introduce nuclear power: increased financial capacity, most likely through foreign investments; a more developed institutional infrastructure; and regulations and controls regarding safety concerns. ${ }^{220}$

Nevertheless, Morocco aspires to become the first African country with a nuclear power facility, ${ }^{221,222}$ and its pursuit of nuclear energy could be related to a regional balance-of-power agenda, including possible rivalry with Algeria. The Center for Nonproliferation Studies comments:

"It is likely that Algeria's nuclear program remains a source of residual concern for Rabat, due to Morocco's competition with Algeria for leadership and prestige in Northern Africa, which has likely been an implicit factor in Morocco's decision to publicize its plan for nuclear procurement.",223

\footnotetext{
${ }^{217}$ Tabet, Mohammed. "Prospects of Nuclear Desalination in Morocco," Int. J. Nuclear Desalination, Vol. 1 No. 4, 2005. Accessed 23 April 2007. http://www.inderscience.com/storage/f211934681271051.pdf

218 "Morocco Planning Start of Nuclear Plant Negotiations Within Two Years," Nucleonics Week, 15 May 1986. Accessed via Nuclear Threat Initiative Research Library archives, 23 April 2007. http://www.nti.org/db/nuclear/1986/n8600639.htm

${ }^{219}$ Tabet, Mohammed. "Prospects of Nuclear Desalination in Morocco," Int. J. Nuclear Desalination, Vol. 1 No. 4, 2005. Accessed 23 April 2007. http://www.inderscience.com/storage/f211934681271051.pdf ${ }^{220}$ Ibid.

${ }^{221}$ Le Monde. "Moscou veut vendre une centrale nucéaire au Maroc," abstract. Article published 19 March 2007. Accessed 20 April 2007. lemonde.fr

${ }^{222}$ Salama, Sammy, and Heidi Weber. "The Emerging Arab Response to Iran's Unabated Nuclear Program," Center for Nonproliferation Studies, Monterey Institute for International Studies. 22 December 2006. Accessed 20 April 2007. http://www.nti.org/e_research/e3_83.html ${ }^{223}$ Ibid.
} 
Relations between Morocco and Algeria have been strained for the past several decades, due to Algeria's continued support for the Polisario Front, which is the rival army of Morocco in the disputed territory of Western Sahara. Nonetheless, the countries have full diplomatic relations, and there is "periodic high-level contact" between them. ${ }^{224}$

The United States has historically partnered with this long-term ally, stationing some nuclear weapons in Morocco prior to its independence from France in 1956. Morocco has not shown any public interest in developing nuclear weapons. Rather, its leadership has consistently supported a nuclear weapons-free zone in the Middle East and Africa.

The Minister for Foreign Business and Cooperation affirmed Morocco's support for a nuclear weapons-free world in 2001: "Morocco... adheres to the Principle of the total elimination of the weapons of mass destruction, and in particular nuclear weapons." He also called upon all states to join the Comprehensive Nuclear Test Ban Treaty "without further delay." 225 More recently, a Moroccan representative to the UN's Sixtieth General Assembly stated that, "Morocco remained alarmed at the situation in the Middle East and the fact there was no establishment of nuclear-weapon-free zones. Morocco's commitment to general and complete disarmament stemmed from a firm conviction that international security depended on Member States giving a special place to the economic and social development the world over."226

Morocco has further established its commitment to the peaceful uses of nuclear energy by its participation in international conferences and relations. Representatives from twelve nations recently met in Morocco to discuss countering the threat of nuclear terrorism via the implementation of the Global Initiative to Combat Nuclear Terrorism. Regarding the choice of location for the October 2006 meeting in Rabat, Robert Joseph, the United States Under Secretary of State for arms control and international security, "said Rabat was a logical choice to launch this diplomatic effort because Morocco has very strong nonproliferation and counterterrorism credentials. He also said the Moroccan government was instrumental in negotiating the related International Convention for the Suppression of Act of Nuclear Terrorism."227 During the conference, Morocco became the first Arab nation to join the initiative. ${ }^{228}$

The only observable concern may be related to Morocco's international collaborations. News media allege that the lead Pakistani nuclear scientist, Abdul Qadeer

\footnotetext{
${ }^{224}$ Bureau of Near Eastern Affairs. "Background Note: Morocco,” U.S. Department of State, February 2007. Accessed 24 April 2007. http://www.state.gov/r/pa/ei/bgn/5431.htm\#econ

225 "Declaration of S.E. Mr. Mohammed Benaissa, Minister for Foreign Business and Cooperation," The Conference on Facilitating the Entry into Force of the Comprehensive Nuclear-Test Ban Treaty, 11

November 2001. Accessed 23 April 2007. [edited for clarity] http://www.fas.org/nuke/control/ctbt/review01/11nov_morocco.htm

${ }^{226}$ Statements made by Siham Mourabit at the UN's Sixtieth General Assembly, First Committee. "NPT Disarmament Obligations, Nuclear-Weapon Convention, Reducing Nuclear Danger among issues addressed in First Committee Texts," News and Media Division, Department of Public Information, UN General Assembly: New York. 10 November 2005. GA/DIS/3301. Accessed 23 April 2007. http://www.un.org/News/Press/docs/2005/gadis3301.doc.htm

${ }^{227}$ Porth, Jaquelyn S. "Nations Meet in Morocco on How To Counter Nuclear Terror Threat," Washington File, 30 October 2006. Accessed 23 April 2007. http://usinfo.state.gov/usinfo/products/washfile.html 228 "Morocco joins global anti-nuclear terrorism initiative," AlJazeera Magazine, 31 October 2006. Accessed 23 April 2007. http://www.aljazeera.com/me.asp?service_ID=12128
} 
Khan, has made multiple trips to several uranium-rich African countries, including Morocco. $^{229}$

\section{ECONOMIC}

\section{Electricity}

Morocco produces 18.48 billion kWh of electricity and consumes 18.89 billion kWh annually. ${ }^{230}$ The National Office of Electricity (ONE), based in Casablanca, is responsible for energy generation, transmission and distribution in Morocco. One of its major goals has been to provide electricity access to the rural areas and to all Moroccans by 2007 through the Global Rural Electrification Program. By 2005, the rate of access to electricity in rural areas reached $72 \%$. Consequently, the number of new customers for electricity has increased about $11 \%$ annually for the past several years, ${ }^{231}$ and considering Morocco's population growth rate of $1.5 \%$, electricity generation has not been able to keep pace with this increased demand. Morocco therefore imports 1.7 billion $\mathrm{kWh}$ of electricity annually and does not export electricity. ${ }^{232}$

ONE has invested significant resources in renewable energy programs, with a plan to increase the share of renewable energy generation from $0.24 \%$ in 2003 to $10 \%$ in 2011. The plan calls specifically for two new wind power facilities in Essaouira and Tangiers, producing $60 \mathrm{MW}$ and $140 \mathrm{MW}$, respectively; it also aims to establish a 220 MW thermo-solar facility in Ain-Mokhtar. Other solar power endeavors have supplied 16,000 rural homes with solar power, and a contract to supply another 20,000 more rural homes was awarded to Apex-BP in 2004. The US Energy Information Administration (EIA) also cites Morocco's rivers and dams as potential sources for hydroelectricity generation. $^{233}$ (EIA 2004)

\footnotetext{
${ }^{229}$ Harris. "Pakistani Nuclear Scientist Made Visits to Uranium-Rich African Countries," Associated Press, 17 April 2004. http://www.nti.org/d_newswire/issues/2004/4/19/7150e621-6e8e-47b6-9b9aa0bb516048d2.html

${ }^{230}$ Central Intelligence Agency. "Morocco," The World Factbook. Last updated 17 April, 2007. Accessed 19 April, 2007. https:/www.cia.gov/library/publications/the-world-factbook/geos/mo.html

${ }^{231}$ Nakkouch, Ahmed. Annual Report 2004. Office National de l'Electricité. Accessed 23 April 2007. http://www.one.org.ma/

${ }^{232}$ Central Intelligence Agency. "Morocco," The World Factbook. Last updated 17 April, 2007. Accessed 19 April, 2007. https:/www.cia.gov/library/publications/the-world-factbook/geos/mo.html

${ }^{233}$ Energy Information Administration. "Country Analysis Briefs: Arab Maghreb Union", U.S. Department of Energy, April 2006. Accessed 1 June 2007. http://www.eia.doe.gov/emeu/cabs/morocco.html
} 


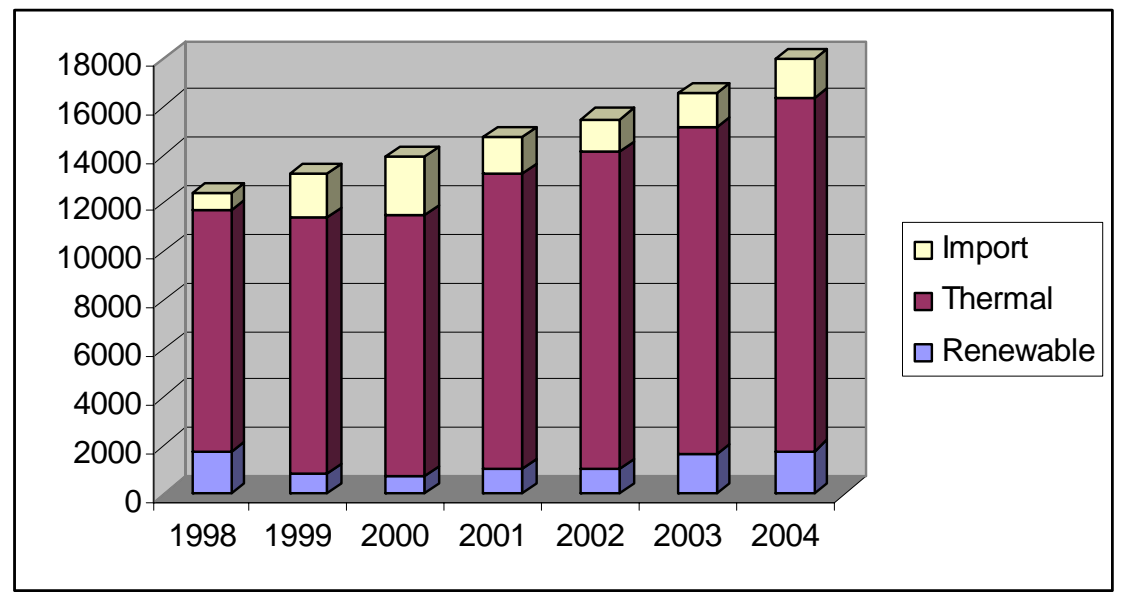

Figure 3. Provision of generation resources for energy growth by type (in GWh). ${ }^{234}$

Morocco's electric grid is connected to that of Algeria and Spain, and Morocco has acknowledged that it would like to eventually link its electricity systems to the European Union's single energy market.

Note: Spain and Turkey (via Bulgaria) are connected to the European UTCE system

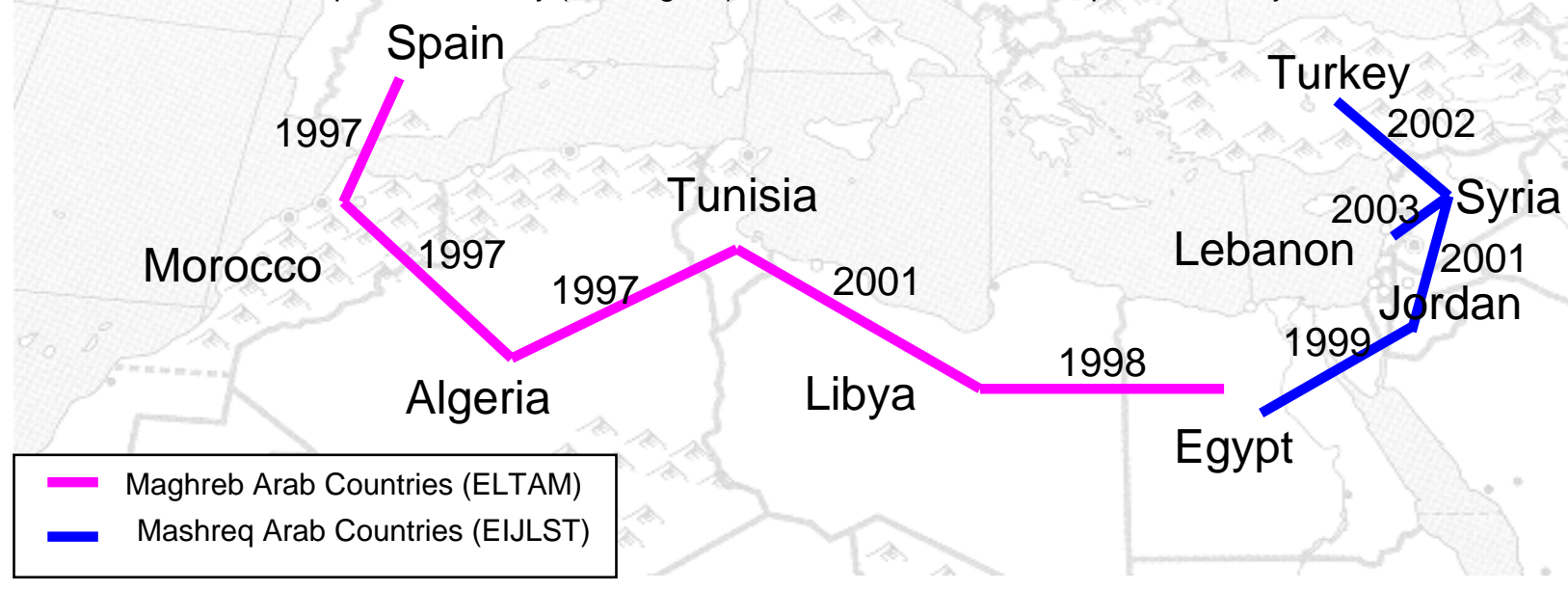

Figure 4. Interconnection of Electric Grids in the Middle East and North Africa. ${ }^{235}$

Oil

Morocco consumes $170,000 \mathrm{bbl}$ per day of oil, of which nearly all $(147,800 \mathrm{bbl}$ per day) is imported. Only $300 \mathrm{bbl}$ per day is produced domestically; domestic production constitutes no more than $0.2 \%$ of consumption. Morocco's heavy reliance

\footnotetext{
${ }^{234}$ Nakkouch, Ahmed. Annual Report 2004. Office National de l'Electricité. Accessed 23 April 2007. http://www.one.org.ma/

235 "The Potential for Regionally Integrated Energy Development in Africa", World Energy Council 2007. Accessed 21 May 2007. Dates shown are as listed in this source, which are likely dates when construction began. Other sources list various other dates of completion of construction, or when the grids came online. http://www.worldenergy.org/wec-geis/publications/reports/africa/cooperation/cooperation.asp
} 
upon imports for oil contributes to its balance-of-payments deficit, particularly with increasing oil prices. In 2004, the EIA estimated the total cost of its energy imports as fluctuating between $\$ 1$ billion and \$1.5 billion per year. ${ }^{236}$ Morocco's reserves amount to about 100 million bbl. ${ }^{237}$

\section{Natural Gas}

Morocco both produces and consumes 50 million cubic meters of natural gas; it does not import or export this resource. Morocco is estimated to have about 1.218 billion cubic meters of natural gas reserves, which would last no more than 25 years at the current rate of consumption. ${ }^{238}$ Currently, Morocco is a transit center for Algerian gas exports to Spain and Portugal through the Maghreb-Europe pipeline. ${ }^{239}$ Morocco has plans to use natural gas from the pipeline to power a generation plant in Al Wahda.

\section{INTERNATIONAL TREATY AND AGREEMENT COMMITMENTS}

\section{IAEA Membership and International Treaty Commitments}

Morocco became a member of the IAEA in September 1957. It joined the United Nations in 1956, and has signed and ratified several international agreements related to nuclear programs. Morocco established a Safeguards Agreement with the IAEA in 1975 and signed the Additional Protocol in September 2004, but it has not yet brought it into force. ${ }^{240}$ The U.S. Nuclear Regulatory Commission notes that, "The International Atomic Energy Agency has not indicated any safeguards violations in Morocco in its annual Safeguards Implementation Reports. $" 241$

Morocco has signed the Limited (Partial) Test Ban Treaty and ratified it in 1966; it signed the Comprehensive Test Ban Treaty in 1996 and ratified it in April 2000. Morocco signed the Nonproliferation Treaty in 1968 and ratified this treaty two years later. $^{242,243,244}$

\footnotetext{
${ }^{236}$ Energy Information Administration. "Country Analysis Briefs: Arab Maghreb Union”, U.S. Department of Energy, April 2006. Accessed 1 June 2007. http://www.eia.doe.gov/emeu/cabs/morocco.html

${ }^{237}$ Central Intelligence Agency. "Morocco," The World Factbook. Last updated 17 April, 2007. Accessed 19 April, 2007. https://www.cia.gov/library/publications/the-world-factbook/geos/mo.html

${ }^{238}$ Central Intelligence Agency. "Morocco," The World Factbook. Last updated 17 April, 2007. Accessed 19 April, 2007. https://www.cia.gov/library/publications/the-world-factbook/geos/mo.html

${ }^{239}$ Energy Information Administration. "Country Analysis Briefs: Arab Maghreb Union", U.S. Department of Energy, April 2006. Accessed 1 June 2007. http://www.eia.doe.gov/emeu/cabs/morocco.html

${ }^{240}$ International Atomic Energy Association. "Strengthened Safeguards System: Status of Additional Protocols," 22 March 2007. Accessed 10 April 2007. http://www.iaea.org/OurWork/SV/Safeguards/sg_protocol.html

${ }^{241}$ Lee, Janice Dunn. "Proposed Renewal of the Section 123 Agreement for Peaceful Nuclear Cooperation with Morocco," U.S. Nuclear Regulatory Commission, 2 March 2001. SECY-01-0033. Accessed 24 April 2007. http://www.nrc.gov/reading-rm/doc-collections/commission/secys/2001/secy2001-0033/20010033scy.html

${ }^{242}$ Bureau of Verification, Compliance, and Implementation, U.S. Department of State. "Treaty Banning Nuclear Weapon Tests in the Atmosphere, in Outer Space, and Under Water." Accessed 9 April 2007. http://www.state.gov/t/ac/trt/4797.htm\#signatory
} 
The country is also a member of the African Nuclear Weapons Free Zone Treaty, the Conference on Disarmament, the Chemical Weapons Convention, the Biological and Toxin Weapons Convention, and the Geneva Protocol. ${ }^{245}$

Though Morocco has signed and ratified some important legal agreements, such as the Convention on the Physical Protection of Nuclear Material and the Joint Convention on the Safety of Spent Fuel Management and on the Safety of Radioactive Waste Management, it has yet to ratify other conventions crucial to the development of a nuclear power facility. Among those signed but not yet ratified are the Vienna Convention on Civil Liability for Nuclear Damage, the Convention on Nuclear Safety, and, as noted above, the Additional Protocol to the Safeguards Agreement. For a full list of Morocco's commitments to multilateral conventions and safeguards agreements with the IAEA, see Appendix F.

\section{IAEA Technical Cooperation Projects}

Morocco is involved in 15 national Technical Cooperation (TC) projects, 38 regional projects, and 7 interregional projects. ${ }^{246}$ The IAEA's TC Country Overview summarizes the Moroccan program as "covering mainly the areas of application of isotopes and radiation in food and agriculture, health, water management, nuclear engineering and technology, and nuclear safety." TC projects have established IAEA cooperation with Morocco on the development of its research reactor, isotope techniques for the investigation of groundwater and hydrology, the introduction of new nuclear medicine techniques and treatment planning in radiotherapy, and strengthening the national radiation protection infrastructure. The IAEA has also participated with Morocco's agricultural sector in the areas of animal production, mutation breeding, nitrogen fixation, pesticide residue monitoring, and food irradiation. Other projects have been directed towards developing spent fuel management, human resource development, air pollution treatment, nuclear security, and radiological and nuclear emergency response. $^{247}$

\section{REGIONAL PROJECT POSSIBILITIES}

Morocco has close international relations particularly with the United States and France. The U.S. State Department expands in its Background Notes,

\footnotetext{
${ }^{243}$ CTBTO Preparatory Commission. "Status of Signature and Ratification." 2007. Accessed 9 April 2007. http://www.ctbto.org

${ }^{244}$ Al-Shamma', Muhammad. "Egypt, Morocco Sign Energy Protocol," Al-Akhbar, Cairo, 1 February 1989. Accessed via Nuclear Threat Initiative, 24 April 2007. http://www.fas.org/nuke/control/npt/text/npt3.htm

${ }^{245}$ Center for Nonproliferation Studies, Monterey Institute of International Studies. http://cns.miis.edu

${ }^{246}$ International Atomic Energy Agency. "Information Records on Morocco," 2005. Accessed 24 April 2007. http://www-tc.iaea.org/tcweb/regionalsites/africa/country/default.asp?cid=MOR

${ }^{247}$ International Atomic Energy Agency. "Country Overview for Morocco," 2005. Accessed 24 April 2007. http://www-tc.iaea.org/tcweb/regionalsites/africa/documents/MOR2005.pdf
} 
"Morocco is a moderate Arab state which maintains close relations with Europe and the United States. It is a member of the UN and belongs to the Arab League.... Although not a member of the African Union (formerly the Organization of African Unity--OAU), Morocco remains involved in African diplomacy. It contributes consistently to UN peacekeeping efforts on the continent."248

The State Department also lauds Morocco for supporting "the search for peace and moderation in the Middle East." First among Arab and Islamic states to denounce the terrorist attacks of September 11, 2001, and to "declare solidarity with the American people in the war against terror," Morocco was also first of the Arab nations to develop relations with Israel and to condemn Iraq's 1990 invasion of Kuwait. Morocco has experienced domestic terrorism as well, in Casablanca on May 16, 2003, which caused over 100 casualties. More than a million people subsequently demonstrated to condemn the attacks. (US Department of State 2007)

A major hurdle to Morocco's international relations remains the dispute over Western Sahara. Morocco claims and administers Western Sahara, rich in phosphate deposits, whose national sovereignty remains unresolved. After years of military combat, a UN-administered cease-fire has remained in effect since September 1991.

Morocco maintains close ties with Saudi Arabia and the Persian Gulf states, which have given Morocco substantial financial assistance. In 1989, Egypt and Morocco signed a technical cooperation protocol in the fields of traditional and nuclear energy and the mining industries. ${ }^{249}$

Barring this dispute, possibilities for Morocco's international collaboration abound. The United States is already closely participating in Morocco's nuclear development, as the American company General Atomic is building the first nuclear research reactor, under U.S. government oversight. France's highly developed nuclear program could be instrumental to the development of Morocco's, as it is second in the world in nuclear electricity production, and particularly considering their already close trade relations, shared language, French economic aid for Morocco's energy programs, and French institutional and technical cooperation. ${ }^{250}$ As Egypt and Morocco have already established a protocol for technical cooperation, the countries could work together on a nuclear power development program, with Egypt's technological advice and Morocco's supply of phosphates for nuclear fuel. Saudi Arabia and the Gulf Cooperation Council (GCC) may be able to finance the construction of a nuclear reactor in Morocco in exchange for exported electricity or other incentives; this would allow for American preferences for nuclear technology to remain concentrated in Morocco while achieving the GCC goal of developing a nuclear power program.

\footnotetext{
${ }^{248}$ Bureau of Near Eastern Affairs. "Background Note: Morocco," U.S. Department of State, February 2007. Accessed 24 April 2007. http://www.state.gov/r/pa/ei/bgn/5431.htm\#econ

${ }^{249}$ Al-Shamma', Muhammad. "Egypt, Morocco Sign Energy Protocol," Al-Akhbar, Cairo, 1 February 1989. Accessed via Nuclear Threat Initiative, 24 April 2007.

http://www.fas.org/nuke/control/npt/text/npt3.htm

250 "Trame de l'intervention de Monsieur l'Ambassadeur de France au Maroc," Le séminaire international sur "Les défis énergétiques du 21ème siècle pour le Maroc et pour l'Europe", La Fédération de l'énergie de la Confédération générale des entreprises du Maroc (CGEM): Rabat, 27 January 2005. Accessed 24 April 2007. http://inis-a4.iaea.org/fulltext/p/37/121/37121733.pdf
} 


\section{LIBYA}

Overview

Libya is located in northern Africa bordering the Mediterranean Sea. Formerly on the US Government's list of state sponsors of terrorism, Libya's government has recently sought to normalize relations with the United States and the world. Politically and economically isolated in the 1990's by the chief of state's refusal to comply with U.S. and UN requirements, Libya ultimately denounced terrorism, accepted responsibility for its actions, and proffered recompense to terrorism victims in 2003. Since then, its international relations have improved, and particularly through its trade in oil and petroleum products, Libya's economy has liberalized and expanded.

Libya is slightly larger than Alaska, and ranks $16^{\text {th }}$ in the world by area; however, only $1 \%$ of its land is arable, and ninety percent of the population lives primarily along the northern coast, in less than $10 \%$ of the country's area. With just over 6 million people, Libya ranks $106^{\text {th }}$ in the world by population, and is home to about nine thousand Palestinian refugees. Libya's population is 97\% Berber and Arab, and 97\% Sunni Muslim as well.

The Libyan economy depends primarily upon revenues from the oil sector, which contribute about $95 \%$ of export earnings, about one-quarter of GDP, and $60 \%$ of public sector wages. The combination of oil export revenues and a small population gives Libya a high nominal GDP per capita by African standards of $\$ 12,700$, compared to the world average of $\$ 10,000$, but little of this income flows down to the lower orders of society. The lifting of UN sanctions in September 2003 in response to Libya's abandonment of its weapons of mass destruction program aided progress on economic reforms; GDP per capita has almost doubled since that year, and GDP growth rate was 8.1\% for 2006. Unemployment, though, remains high at $30 \%$. Climatic conditions, an extremely limited fresh water supply, and poor soils severely limit agricultural output, and Libya imports about $75 \%$ of its food.

Libya's per capita energy consumption is about $3,000 \mathrm{kWh}$, quite low compared to $12,454 \mathrm{kWh}$ in the US, yet comparable to the $2,962 \mathrm{kWh}$ of the world average. Libya is also $33^{\text {rd }}$ in the world for military expenditures as a percent of GDP at $3.9 \%$, a percentage which is approximately similar to that of the US (though the dollar amount is clearly much smaller). ${ }^{251,252}$ (CIA Factbook 2007, U.S. Department of State 2007)

An extraordinary reversal of Libyan policy regarding nuclear weapons dominates the country's recent political history. Until late 2003, Libya was actively pursuing a nuclear weapons program, including enrichment, conversion, design knowledge, technology, and production facilities. After nine months of secret negotiations with the United States and the United Kingdom, Libya announced its intention to renounce all of its WMD programs, and has since acted with international participation to dismantle the facilities, remove all highly enriched uranium, and to transform its nuclear program for peaceful research purposes. Since the disclosure of Libya's nuclear program, reports

\footnotetext{
${ }^{251}$ Bureau of Near Eastern Affairs. "Background Note: Libya,” U.S. Department of State, February 2007. Accessed 25 April 2007. http://www.state.gov/r/pa/ei/bgn/5425.htm

${ }^{252}$ Central Intelligence Agency. "Libya," The World Factbook. Last updated 17 April, 2007. Accessed 25 April 2007. https://www.cia.gov/library/publications/the-world-factbook/geos/ly.html
} 
have indicated that the country's extensive efforts did not bring the nation appreciably close to a nuclear weapon, though they did succeed in attaining advanced technology in select areas. Libya's expansive oil resources intimate that nuclear power for electricity purposes would not be economically advantageous, though perhaps more environmentally friendly. The most promising prospects of nuclear power applications would be nuclear desalination for the barren country, but other water resources are currently being developed and may be more economic as well. Consistent improved international relations, reliable adherence to nuclear conventions and agreements, strengthened legislative infrastructure, expanded regulation and technical background, and the demonstration of a clear necessity for nuclear power could all be included in prerequisites for the development of a nuclear power program in Libya.

\section{NUCLEAR INFRASTRUCTURE/INTENTIONS}

\section{Infrastructure}

\section{Knowledge management}

Libya has a labor force of 1.8 million people, of whom $23 \%$ work in industry. The literacy rate is quite high for Africa, at $82.6 \%$, though there is a disparity between male and female literacy rates ( $94.4 \%$ and $72 \%$, respectively).

The main nuclear research and training facility in Libya is the Tajoura Nuclear Research Centre (TNRC) in Tripoli. The TNRC was established in 1983 "to solve problems of economic significance to the country via peaceful application of atomic energy." ${ }^{253}$ The center aims to conduct fundamental and applied research, advanced study, and training in peaceful applications of nuclear energy. The center's National Bureau of Research and Development became a sister laboratory of the National Nuclear Security Administration (NNSA) in 2005, when they established an arrangement for scientific collaboration. This agreement is said to demonstrate the U.S. and Libyan commitment "to the peaceful uses of nuclear energy.... Scientists from the laboratories of the two organizations say they look forward to beginning joint activities under this program, which will focus on research reactor applications, including nuclear medicine, and other applied scientific endeavors." 254 Training at TNRC is conducted either in foreign university systems or in on-the-job training. ${ }^{255}$ The center's research capabilities are described in more detail below.

Libya also participates in the NNSA's Reduced Enrichment for Research and Test Reactors Program, which seeks "to develop the technical means to convert the reactors and isotope production processes from the use of highly enriched uranium (HEU) to the use of low enriched uranium (LEU)."256 Russia supplied Libya's IRT-1 reactor with LEU

\footnotetext{
253 Tajoura Nuclear Research Centre, "Research Facilities". http://www.tnrc.org

${ }^{254}$ National Nuclear Security Administration. "U.S. and Libya Sign Sister Laboratory Agreement", September 2005. Accessed 30 April 2007.

http://www.nnsa.doe.gov/docs/newsletters/2005/nl_2005Sep_NNSA_News.pdf

${ }^{255}$ Pike, John. "Weapons of Mass Destruction: Tajoura Nuclear Research Centre”, GlobalSecurity.org, 28 April 2005. Accessed 27 April 2007. http://www.globalsecurity.org/wmd/world/libya/tajura.htm ${ }^{256}$ Office of Defense Nuclear Nonproliferation. "Reduced Enrichment for Research and Test Reactors Program”, National Nuclear Security Administration. http://www.nnsa.doe.gov/na-20/rertr.shtml
} 
fuel in December 2005. Conversion of Libya's critical facility was completed in January 2006, while conversion of its $10 \mathrm{MW}$ reactor is planned to be completed in summer $2006 .{ }^{257}$

The IAEA lists several other research institutes "actively publishing in the nuclear field." These include the Physics and Mathematics Department of Omar Al-Mukhtar University in El-Beida, the Physics Department of the University of Garyounis in Benghazi, Libya's Ministry of Energy, and the Department of Physics at Al-Fateh University in Tripoli. ${ }^{258}$ In an independent literature search, recent research publications were found only for University of Garyounis and Al-Fateh University.

Libya has conducted research in hopes of developing a nuclear program for decades, but it has always been limited by technical capability. The country's interest in nuclear weapons limited Libyan students' access to foreign university programs, and there was never sufficient domestic knowledge to build a complete nuclear program. John Pike of Global Security notes, "Libya is in no position to obtain access to nuclear weapons in the foreseeable future, given the extremely limited domestic technical base of the country." ${ }^{259}$ Through collaboration with the NNSA and other agencies, Libya may gain enough technical expertise for a nuclear energy program, and careful monitoring and export controls may limit the spread of nuclear weapons information.

\section{Uranium Resources}

Neither the IAEA's World Distribution of Uranium Deposits Database $(\mathrm{UDEPO})^{260}$ nor Uranium 2005: Resources, Production, and Demand, ${ }^{261}$ nor other open source literature ${ }^{262}$ list any uranium resources in Libya.

\section{Nuclear Reactors and Fuel Facilities}

Libya's nuclear program includes one research reactor and other research facilities. The one research reactor in operation, IRT-1, is owned and operated by Tajoura Nuclear Research Center (TNRC). This Soviet-designed reactor was constructed in 1979, with a criticality date of 28 August 1981. It is a light water pool-type reactor with $10 \mathrm{MW}$ of steady thermal power capability, though normal thermal operation is 5 MW. The reactor has a maximum thermal neutron flux of $2 \times 10^{14} \mathrm{n} / \mathrm{cm}^{2}$-s. Ten horizontal channels are used for nuclear physics and solid state physics research; 35 vertical channels are used for radioisotope production. Fissile material for this reactor originated in Russia; Russia enriched and fabricated the fuel, which is $80 \%$ enriched

\footnotetext{
${ }^{257}$ Nuclear Threat Initiative: Past and Current Efforts to Reduce Civilian HEU Use, http://www.nti.org/db/heu/pastpresent.html. Accessed 8 August 2007.

258 International Atomic Energy Agency. "Nuclear Research in Libyan Arab Jamahiriya," 2003-2004. Accessed 30 April 2007. http://www.iaea.org/inisnkm/nkm/ws/research_institutes/libyan_arab_jamahiriya.html ${ }^{259}$ Pike, John. "Weapons of Mass Destruction: Libyan Nuclear Weapons", GlobalSecurity.org, 28 April 2005. Accessed 27 April 2007. http://www.globalsecurity.org/wmd/world/libya/nuclear.htm ${ }^{260}$ Integrated Nuclear Fuel Cycle Information Systems, World Distribution of Uranium Deposits Database. International Atomic Energy Agency. 2003. Accessed 25 April 2007. http://www-nfcis.iaea.org/

${ }^{261}$ Joint Report by the OECD Nuclear Energy Agency and the International Atomic Energy Agency. Uranium 2005:Resources, Production, and Demand, Paris: OECD Publishing, 2005. p. 215-9.

${ }^{262}$ Stockholm International Peace Studies Institute. "Countries of Strategic Nuclear Concern - Libya, Nuclear Facilities Profile.” July 2004. Accessed 26 April 2007. http://www.sipri.org/contents/expcon/cnsc3lya.html
} 
uranium, as well. $^{263}$ Support for its operation was discontinued by Russia in 1991, though since the suspension of UN sanctions in 1999, Russia signed a contract with Libya for its partial reconstruction in order to modernize the facility. The reactor is under IAEA safeguards as of December 2003.

TNRC also houses a "critical facility," which includes a critical assembly, a neutron generator, and a TM4-A Libtor Tokamak fusion reactor. The tokamak is a zeropower critical reactor mockup of the research reactor, presumably the 10MW research reactor, also located at TNRC. The tokamak's thermal neutron flux is the same as that of IRT-1, and it has 16 uranium-aluminum fuel assemblies.

At the TNRC are also radiochemical facilities intended for the production of radioactive isotopes for application in medicine, agriculture, industry, \& environment. ${ }^{264}$ TNRC has a hot cell facility containing six cells equipped with "lead glass, concrete shielding and master slave manipulators for handling curie levels of gamma sources," as well as millicurie levels of beta and gamma emitting isotopes. ${ }^{265}$ The Stockholm International Peace Research Institute comments that this may suggest that the facility has a limited reprocessing capability. ${ }^{266}$

Libya developed a Uranium Conversion Facility (UCF) that is now no longer in operation. In 1984, Libya ordered a "pilot scale uranium conversion facility" from the Soviet Union. ${ }^{267}$ It was received in 1984, but most of the equipment was not delivered until 1994, and cold testing was conducted in February 2002. ${ }^{268}$ Originally located at Sawani, the UCF was moved a few times, first to Al Khalla and later to Salah Eddin. Milling and waste treatment modules remained at the Sawani site. The plant has an estimated annual feed capacity of 30 tons uranium and could produce $\mathrm{UF}_{4}, \mathrm{UO}_{2}$ and uranium metal; it has no $\mathrm{UF}_{6}$ production capability, though Libya stated that it had tried, unsuccessfully, to acquire $\mathrm{UF}_{6}$ production capability. It has also stated that there has been no domestic $\mathrm{UF}_{6}$ production, even on a laboratory scale. ${ }^{269}$

In the early $1980 \mathrm{~s}$, Libyan technicians initiated a uranium gas centrifuge enrichment program at Tajura, under the oversight of a foreign expert, who was reportedly a former employee of a German technical firm. ${ }^{270}$ The program used a centrifuge design that the expert had brought with him. Yet by the time the expert left, around 1992, Libya later stated that it had not yet constructed an operating centrifuge,

${ }^{263}$ Research Reactor Database. "Nuclear Research Reactors in the World: Libya." International Atomic Energy Agency, 1999. Accessed 25 April 2007. http://www.iaea.org/worldatom/rrdb/

${ }^{264}$ Tajoura Nuclear Research Centre, "Research Facilities". http://www.tnrc.org

${ }^{265}$ Stockholm International Peace Studies Institute. "Countries of Strategic Nuclear Concern - Libya, Nuclear Facilities Profile.” July 2004. Accessed 26 April 2007.

http://www.sipri.org/contents/expcon/cnsc3lya.html

${ }^{266}$ Ibid.

${ }^{267}$ International Atomic Energy Agency. "Implementation of the NPT Safeguards Agreement of the Socialist People's Libyan Arab Jamahiriya," Report by the Director General, 20 February 2004. GOV/2004/12.

${ }^{268}$ International Atomic Energy Agency. "Implementation of the NPT Safeguards Agreement of the Socialist People's Libyan Arab Jamahiriya," Report by the Director General, 30 August 2004.

GOV/2004/59. Accessed 1 May 2007. http://www.fas.org/nuke/guide/libya/iaea0804.pdf

${ }^{269}$ Ibid.

${ }^{270}$ Nuclear Threat Initiative. "Libya Profile: Nuclear Overview," Center for Nonproliferation Studies, Monterey Institute of International Studies. Updated 2006. Accessed 27 April 2007.

http://www.nti.org/e_research/profiles/Libya/3939.html\#fnB20 
and no experiments had been conducted using nuclear material. In late 2000, Libya started to progressively install 9-machine, 19-machine and 64-machine L-1 centrifuge cascades, which had been imported, at Al Hashan. Libya later disclosed that it had placed an initial order for 5,000 centrifuges based on this design, which was later extended to 10,000 machines. Pakistan and perhaps other countries manufactured the components for the centrifuges, and according to a subsequent IAEA report, they began to arrive in "large quantities" in December 2002. ${ }^{271}$ By late December 2003, Libya had received a considerable number of parts, but these were mainly casings and lacked rotors, so were not yet operational.

At the TNRC during the 1980s, Libya also conducted undeclared laboratory-scale and bench-scale uranium conversion experiments using imported uranium ore concentrate ("yellowcake") and possibly other imported uranium compounds. Twentytwo kilograms of natural uranium were used in experiments. (IAEA 2004)

Furthermore, Libya conducted the fabrication of several dozen small uranium oxide and uranium metal targets on a gram scale. Some of these were subsequently irradiated in the Tajura Research Reactor between 1984 and 1990, "to produce mainly fission product radioisotopes." Forty-eight targets were irradiated but not processed. Plutonium, in very small quantities, was separated from at least two of the irradiated targets. $^{272}$

All of these fuel enrichment programs were conducted covertly and in violation of IAEA safeguards. Since Libya's rescinded its WMD programs in 2003, most of the relevant equipment has been transported out of Libya. Open source literature does not report any current fuel fabrication facilities in Libya.

\section{$\underline{\text { Regulation }}$}

Most of the IAEA's Technical Cooperation projects, such as enhancing the safety system of the IRT-1 reactor and human resource development, are conducted in partnership with TNRC's overseeing organization, the Renewable Energies and Water Desalination Research Center. ${ }^{273}$

On policy and planning-oriented TC programs, Tripoli's National Bureau of Research and Development tends to partner with the IAEA. The National Bureau is also a partner with the NNSA in their Sister Laboratory program with Libya.

The precise responsibilities of each of these institutions are not clear from surveyed sources.

\section{Intentions}

\section{Historical Overview}

In order to understand more fully U.S. relations with Libya and to consider Libya's nuclear intentions, it is vital to place Libya's current status in the context of its

\footnotetext{
${ }^{271}$ International Atomic Energy Agency. "Implementation of the NPT Safeguards Agreement of the Socialist People's Libyan Arab Jamahiriya," Report by the Director General, 20 February 2004.

GOV/2004/12. Accessed 1 May 2007. http://www.fas.org/nuke/guide/libya/iaea0204.pdf

${ }^{272}$ Ibid.

${ }^{273}$ International Atomic Energy Agency. “Information Records on Libyan Arab Jamahiriya,” 2005. Accessed 30 April 2007. http://www-tc.iaea.org/tcweb/regionalsites/africa/country/default.asp?cid=LIB
} 
historical background. Strained international relations with Libya began shortly after Qadhafi's rise to power in Libya in 1969. Though he holds no official title, Qadhafi is de facto chief of state. The US State Department affirms that,

"Since 1969, Qadhafi has determined Libya's foreign policy. His principal foreign policy goals have been Arab unity, elimination of Israel, advancement of Islam, support for Palestinians, elimination of outside-particularly Western--influence in the Middle East and Africa, and support for a range of 'revolutionary' causes." ${ }^{274}$

The United States government declared Libya a "state sponsor of terrorism" on 29 December 1979. Libya sponsored several attacks on Americans throughout the 1980's, including the Lockerbie plane crash that killed 189 American civilians. For a brief historical summary of the United States and Libya as regards terrorism, see Appendix G. During the 1980's and 1990's, Libya also pursued an illicit Weapons of Mass Destruction program, including chemical, biological, missile, and nuclear weapon programs. In 2003, Libya admitted that it had intended to produce biological weapons, even though Libya acceded to the Biological and Toxin Weapons Convention in 1982. The country revealed to the U.S. and the U.K. several medical and agricultural research centers that could be used for biological weapons research. Chemical weapons plants at Rabta and Tarhunah could possibly have been used in biological weapons research, and reports indicate that Libya pursued collaboration with South Africa, Cuba, and Iraq on biological weapons. U.S. intelligence agencies also alleged that, prior to 2003, Libya had started to develop pathogens and toxins for weapons use. ${ }^{275}$ Yet Libya's limited research program did not create the technological base to develop weapons of biological agents. ${ }^{276}$

Libya was one of very few nations to utilize chemical weapons (CW) in combat after the World Wars. Libya employed mustard gas bombs, supplied by Iran, against Chad in the midst of a border dispute in 1987, signaling a willingness to resort to unconventional means on a small scale as "an asymmetric response to conventional military inferiority."277 Libya later revealed that it had produced a "significant quantity" of mustard gas at the Rabta plant in the Sahara Desert, and had developed other research facilities at Sebha and Tarhuna. This CW program was allegedly the most expansive chemical weapons facility in the world, and was coupled with a ballistic missile program to deliver the chemicals. ${ }^{278}$ In December 2003, Libya pledged to eliminate all CW stocks

\footnotetext{
${ }^{274}$ Bureau of Near Eastern Affairs. "Background Note: Libya," U.S. Department of State, February 2007. Accessed 25 April 2007. http://www.state.gov/r/pa/ei/bgn/5425.htm

${ }^{275}$ Nuclear Threat Initiative. "Libya Profile: Introduction," Center for Nonproliferation Studies, Monterey Institute of International Studies. Updated 2006. Accessed 26 April 2007. http://www.nti.org/e_research/profiles/Libya/index.html

${ }^{276}$ Nuclear Threat Initiative. "Libya Profile: Biological Overview," Center for Nonproliferation Studies, Monterey Institute of International Studies. Updated 2006. Accessed 27 April 2007. http://www.nti.org/e research/profiles/Libya/3941.html

${ }^{277}$ Nuclear Threat Initiative. "Libya Profile: Introduction," Center for Nonproliferation Studies, Monterey Institute of International Studies. Updated 2006. Accessed 26 April 2007. http://www.nti.org/e_research/profiles/Libya/index.html

${ }^{278}$ Nuclear Threat Initiative. "Libya Profile: Chemical Overview," Center for Nonproliferation Studies, Monterey Institute of International Studies. Updated 2006. Accessed 27 April 2007. http://www.nti.org/e_research/profiles/Libya/3944.html
} 
and accede to the Chemical Weapons Convention "without delay," and OPCW monitored the destruction of 3,500 aerial bombs designed to deliver chemical agents in 2004. ${ }^{279}$

Libya's missile program originally consisted of Scud-B missiles obtained from the Soviet Union. Beginning in the early 1970's, Libya sought to obtain missiles with a range of up to $950 \mathrm{~km}$. Germany and China allegedly provided technical assistance and materials for the missile system for some years, but the system was never tested or completed. North Korea supplied Libya with 50 Nodong ballistic missiles with launch capabilities, as well as 10 missile scientists to work on Libya's program for $\$ 600$ million in the late 1990's according to allegations. Reports have also indicated assistance provided from Iran, North Korea, China, India, and Russia. In December 2003, Libya pledged to eliminate ballistic missiles capable of traveling more than $300 \mathrm{~km}$ with payloads of $500 \mathrm{~kg}$, and four months later, the Libyan government communicated that it planned to convert hundreds of its Scud-B missiles into short-range defensive weapons and to discontinue all military trade with North Korea. Inspectors observed six Scud-C missiles in Libya's stockpiles, which have a $550 \mathrm{~km}$ range and $500 \mathrm{~kg}$ payload; according to reports, some of these have been removed from the stockpiles. ${ }^{280}$ The U.S. State Department has since announced that the complete dismantling of Libya's WMD programs has been verified. Libya is not a member of the Missile Technology Control Regime (MTCR). ${ }^{281}$

Libya began expressing interest in a nuclear weapons program in the late 1960's, presumably in response to Israel's rise to nuclear power. In 1968 Libya signed the Nonproliferation Treaty under the reign of King Idris, and ratified it under Qadhafi in 1975; Libya also acceded to a safeguards agreement with the IAEA in 1980. During this time, and through 2003, Libya sought to obtain nuclear technology, weapons design, and fissile material from China, Pakistan, Russia, Belgium, France, South Africa, and reportedly North Korea. Libya allegedly attempted to purchase nuclear weapons from China, India, and Pakistan, and to hire nuclear scientists from Germany, the former Soviet Union, and Pakistan.

Though Libya was subject to safeguards, self-reports of its nuclear program vastly underrated the scope of its capability. The IAEA Report on the Implementation of Safeguards in Libya in February 2004 states that,

"Prior to 20 December 2003, Libya's declared nuclear programme consisted of a $10 \mathrm{MW}$ IRT research reactor in operation since 1980, and a Critical Assembly $(100 \mathrm{~W})$, both of which are located at the Tajura Nuclear Research Centre (TNRC). The IRT is a pool-type research reactor using $80 \%$ enriched uranium. Prior to December 2003, the total quantity of declared nuclear material

\footnotetext{
${ }^{279}$ Nuclear Threat Initiative. "Libya Profile: Introduction," Center for Nonproliferation Studies, Monterey Institute of International Studies. Updated 2006. Accessed 26 April 2007. http://www.nti.org/e_research/profiles/Libya/index.html

${ }^{280}$ Nuclear Threat Initiative. "Libya Profile: Missile Overview," Center for Nonproliferation Studies, Monterey Institute of International Studies. Updated 2006. Accessed 27 April 2007. http://www.nti.org/e_research/profiles/Libya/Missile/index.html

${ }^{281}$ Nuclear Threat Initiative. "Libya Profile: Introduction,” Center for Nonproliferation Studies, Monterey Institute of International Studies. Updated 2006. Accessed 26 April 2007. http://www.nti.org/e_research/profiles/Libya/index.html
} 
under safeguards in Libya amounted to $20 \mathrm{~kg}$ of uranium-235 in high enriched uranium fuel and 1000 tonnes of uranium ore concentrate [yellowcake]."282

Libya, however, conducted a clandestine program in imports and exports, fuel enrichment, and nuclear weapons development, and declared activities and supplies were just a small portion of the overall nuclear program, as described below.

Between 1978 and 1981, Libya imported a total of 2,263 tons of yellowcake, reportedly from French-controlled mines in Niger. Only a portion of these imports were reported to the IAEA when the Safeguards Agreement came into force in 1980. Libya exported yellowcake to an undeclared "nuclear weapon state" for reprocessing in 1985, and received back $\mathrm{UF}_{6}(39 \mathrm{~kg}), \mathrm{UF}_{4}(5 \mathrm{~kg}), \mathrm{UO}_{2}(6 \mathrm{~kg})$ and $\mathrm{U}_{3} \mathrm{O}_{8}(6 \mathrm{~kg})$ in the same year. ${ }^{283}$ Other cylinders containing 39 kilograms of $U_{F}$ were imported in 2000 to 2001 containing low-enriched uranium (LEU), natural uranium, and depleted uranium. None of these were reported to the IAEA. Since 2003, all have been transferred out of Libya.

Libya repeatedly attempted to develop fuel enrichment facilities in the 1980's and 1990's. In 1982, Libya attempted to purchase a plant for manufacturing uranium tetrafluoride from the Belgian firm Belgonucleaire, but this request was denied as Libya had no declared nuclear facilities that would require such a plant. However, Libya did develop a pilot scale uranium conversion facility two years later. Libya also tried to purchase enrichment calutrons from the French company Thomson-CSF; the deal was blocked by the French government because of its obvious application to an undeclared nuclear weapons program. The country was successful in obtaining parts for centrifuges, irradiating uranium, and separating very small quantities of plutonium. By late 2000, Libya was in the process of establishing a facility in order to build centrifuges domestically. Libya's past fuel enrichment facilities and capabilities are described in more detail above. The IAEA Safeguards Implementation Report indicates, though, that "The Director General was informed ... that Libya's enrichment programme was at an early stage of development and that no industrial scale facility had been built, nor any enriched uranium produced." 284

\footnotetext{
${ }^{282}$ International Atomic Energy Agency. "Implementation of the NPT Safeguards Agreement of the Socialist People's Libyan Arab Jamahiriya," Report by the Director General, 20 February 2004. GOV/2004/12. Accessed 5 June 2007 http://www.fas.org/nuke/guide/libya/iaea0204.pdf ${ }^{283}$ International Atomic Energy Agency. "Implementation of the NPT Safeguards Agreement of the Socialist People's Libyan Arab Jamahiriya," Report by the Director General, 20 February 2004. GOV/2004/12. Accessed 5 June 2007 http://www.fas.org/nuke/guide/libya/iaea0204.pdf

${ }^{284}$ International Atomic Energy Agency. "Implementation of the NPT Safeguards Agreement of the Socialist People's Libyan Arab Jamahiriya," Report by the Director General, 20 February 2004. GOV/2004/12. Accessed 5 June 2007 http://www.fas.org/nuke/guide/libya/iaea0204.pdf
} 


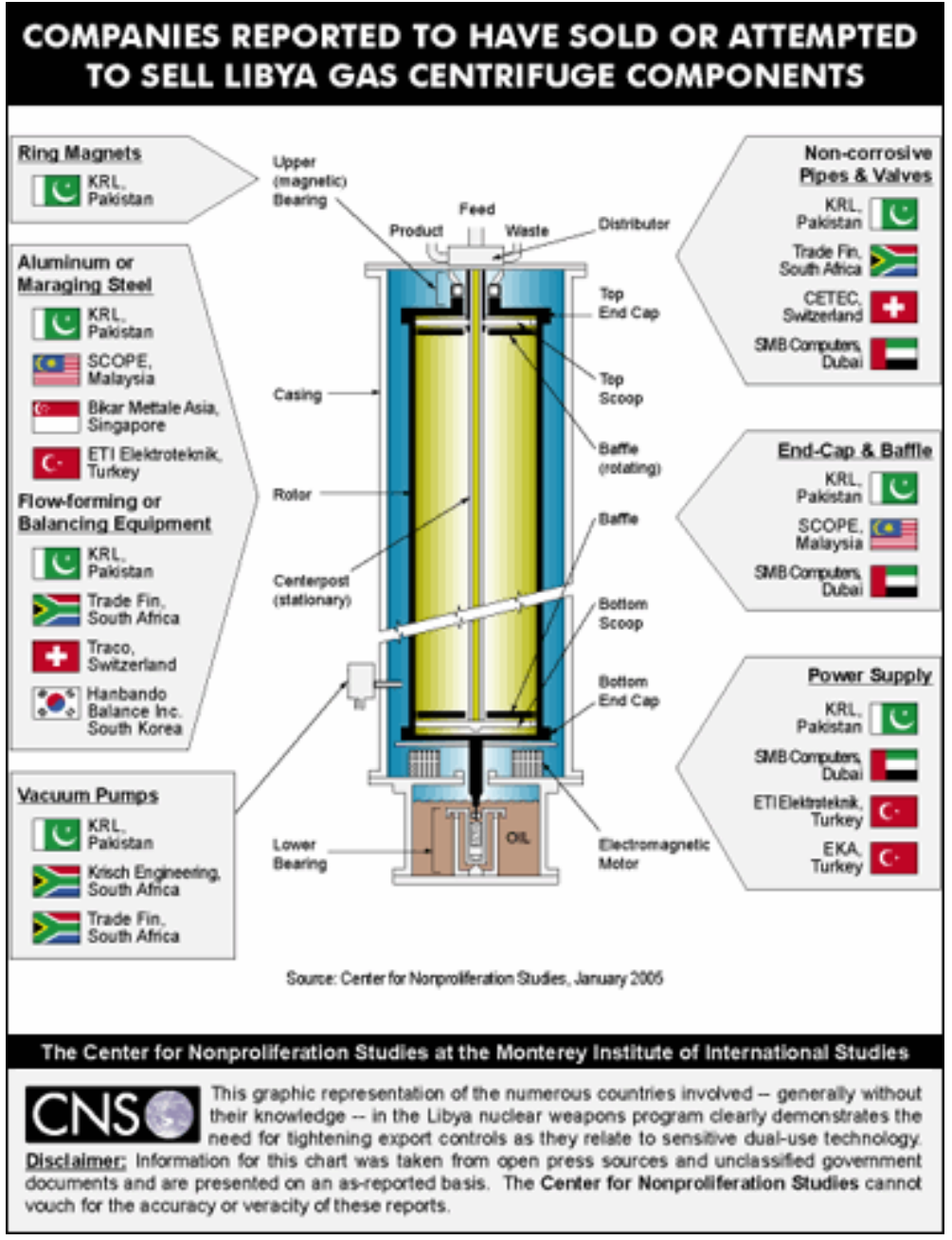

\section{Figure 1. Chart of reported attempted sources for parts for Libya's gas centrifuge program. $^{285}$}

Libya also sought to purchase a larger nuclear reactor than the one at Tajura from France, Soviet Union, and Belgium; each time strong international objections prevented such a transfer.

Nuclear weapons research and development (R\&D) was a strong interest of the Libyans in their nuclear program, though it was never highly developed. Dr. A.Q. Khan, the chief architect of the Pakistani nuclear weapons program and confessed proliferator of nuclear technologies to several countries of concern, including Iran and North Korea, began aiding Libya's nuclear weapons program in 1997. Khan provided Libya with the blueprint of an actual fission weapon, ${ }^{286}$ but "Libya stated that it had had no national personnel competent to evaluate the data and would have asked the supplier for help in

\footnotetext{
${ }^{285}$ Salama, Sammy and Lauren Hall. "Countries Reported to Have Sold or Attempted to Sell Libya Gas Centrifuge Components," Center for Nonproliferation Studies, Monterey Institute of International Studies, March 2005. Accessed 1 May 2007. http://www.nti.org/e_research/e3_60a.html

${ }^{286}$ Nuclear Threat Initiative. "Libya Profile: Nuclear Overview," Center for Nonproliferation Studies, Monterey Institute of International Studies. Updated 2006. Accessed 26 April 2007. http://www.nti.org/e_research/profiles/Libya/3939.html\#fnB20
} 
the event it had opted to take further steps to develop a nuclear weapon." 287 Documents relinquished by Libyans during the dismantling of their program indicated a nuclear weapon design originating in China and smuggled through Pakistan. ${ }^{288}$ This was purportedly the only weapons information in the country. The IAEA reports on 18 locations it inspected "that could have, from a technical standpoint, provided support to a nuclear weapon research and development programme":

"These locations ... included those related to the handling of high explosives, ammunition production, missile propellant fabrication and testing, missile warhead design and manufacturing, metal casting, welding and machining, and chemical and plastic materials research and development and production.... Initial inspections of these locations did not identify specific facilities currently dedicated to nuclear weapon component manufacturing." 289

After 2003, Libya agreed to transfer to the U.S. sensitive design information, nuclear weapon related documents, and most of the previously undeclared enrichment equipment.

During the period of Libya's clandestine pursuit of nuclear weapons, Libya conducted a contradictory public policy. For example, in 1996, Qadhafi called for Arab states to develop a nuclear weapon in response to Israel's nuclear program, and yet he signed the African Nuclear Weapon Free Zone treaty. Qadhafi furthermore issued several calls for the production of nuclear weapons in Libya in the 1990's, yet publicly supported nonproliferation. About that time, increasing concern over Libya's sponsorship of terrorism precipitated expanded economic sanctions to include a total ban on direct import and export trade, commercial contracts, and travel-related activities. This was especially detrimental to Libya's oil industry, the main source of income for the country, as required equipment for oil extraction could not be obtained. In addition, Libyan Government assets in the United States were frozen. Nonetheless, the Libyan government repeatedly spent large amounts of money on its WMD programs during the same time period.

On 19 December 2003, after a nine-month period of secret negotiations with the U.S. and the U.K., Qadhafi publicly announced his commitment to disclose and to dismantle all WMD programs in Libya. Preceding events both complicate and help to explain the astonishment caused by the announcement. In March of that year, mere days before the U.S. invasion of Iraq, Libya told British and American authorities that it could be willing to dismantle WMD programs. In August 2003, Libya accepted responsibility for the Lockerbie disaster and offered to pay recompense to affected families; in return, the UN ended international sanctions against Libya. Yet still in October 2003, Libya was

\footnotetext{
${ }^{287}$ International Atomic Energy Agency. "Implementation of the NPT Safeguards Agreement of the Socialist People's Libyan Arab Jamahiriya," Report by the Director General, 20 February 2004. GOV/2004/12. Accessed 5 June 2007 http://www.fas.org/nuke/guide/libya/iaea0204.pdf

${ }^{288}$ Nuclear Threat Initiative. "Libya Profile: Nuclear Chronology 2004," Center for Nonproliferation Studies, Monterey Institute of International Studies. Updated 2005. Accessed 1 May 2007. http://www.nti.org/e_research/profiles/Libya/4132_5206.html

${ }^{289}$ International Atomic Energy Agency. "Implementation of the NPT Safeguards Agreement of the Socialist People's Libyan Arab Jamahiriya," Report by the Director General, 20 February 2004. GOV/2004/12.
} 
continuing to import crucial parts for its centrifuges, as shown by the interception that month of a German cargo ship sailing from Dubai with purportedly Pakistani-designed centrifuge components, which further appeared to confirm the minatory intent of Libya's nuclear project. Two months later, Libya abnegated its WMD program, opened its doors to IAEA inspections, and has since cooperated with the US and the IAEA. Director General Mohammed ElBaradei stated in late January 2004 that, as part of Libya's disarmament, the IAEA would "verify that Libya's programme is properly dismantled, while the Americans and Britons would physically destroy the capabilities" of Libya's nuclear program as it was uncovered. ${ }^{290}$ Libya's nuclear weapons design information was soon sent to the United States, and shortly thereafter U.S. transport planes carried 55,000 pounds of documents and equipment related to Libya's nuclear and ballistic missile programs to the Oak Ridge National Laboratory in Tennessee. In March 2004, sixteen kilograms of HEU fuel was airlifted to Russia, where it will be blended down into lowenriched uranium fuel. The IAEA Board of Governors adopted a resolution on 10 March 2004 applauding Libya for its decision to abandon its WMD programs, "commending" the country for its "active cooperation" and its "granting of unrestricted access to facilities, the provision of prompt responses to Agency questions, and the volunteering of information relevant to the Agency's verification responsibilities." Though the report also notes with concern Libya's violation of its Safeguards Agreement, and requests that the Director General report Libya's noncompliance to the UN Security Council, it expresses appreciation for "active cooperation and openness," and requests continued cooperation and disclosure. ${ }^{291}$ Libya signed the Additional Protocol to the Safeguards Agreement during this time, and it took force 29 December 2003. US Secretary of State Condoleezza Rice announced the restoration of full diplomatic relations with Libya on May $15,2006 .^{292}$

What motivated Libya to renounce and to relinquish its WMD programs is not certain. Some speculate that the timing of Libya's pronouncement suggests a fear of a preemptive U.S. attack based on allegations of a WMD program, as with Iraq. Others say Libya may also have been motivated by negative international consequences of the October interception of centrifuge components being shipped to the country.

Another speculation was economics. Mutually beneficial economic developments originated from this U.S.-U.K.-Libya agreement. Economic sanctions had prohibited trade in oil and in the equipment used to extract oil, formerly Libya's most profitable export. With the end of the sanctions, America oil companies invested large sums of money in the Libyan economy which greatly contributed to its recovery, while providing an alternate source of oil outside the Persian Gulf for the United States. Nuclear Threat Initiative Researcher Sammy Salama argues that Libya, "having made reparation for its past deeds and demonstrating a willingness to turn a new page with the international

\footnotetext{
${ }^{290}$ Bourseton, Jack, Yana Feldman, and Charles Mahaffey. "Verifying Libya's Nuclear Disarmament," Trust \& Verify, Issue No. 112, The Verification Research, Training, and Information Centre, London. January-February 2004. Accessed 30 April 2007. http://www.vertic.org/assets/TV112.pdf

${ }^{291}$ International Atomic Energy Agency. "Implementation of the NPT Safeguards agreement of the Socialist People's Libyan Arab Jamahiriya, Resolution adopted by the Board," 10 March 2004. GOV/2004/18.

${ }^{292}$ US Department of State. "US Diplomatic Relations with Libya," Secretary of State Condoleezza Rice, 15 May 2006. Accessed 30 April 2007. http://www.state.gov/secretary/rm/2006/66235.htm
} 
community," returned from a long period of not just economic, but also political isolation to the international community. ${ }^{293}$

Though evidence showed Libya was still a few years away from a nuclear weapon and that it appeared to be at an early stage in realizing its nuclear ambitions, the U.S. had a great nonproliferation and diplomatic success. Salama observes, "The United States and its allies were able to disarm an established rogue regime without using force or having to directly commit military or economic assets." Libya provided the U.S. with intelligence on al-Qaeda's network in North Africa. Further, information from the dismantling of Libya's nuclear program led to the exposure of the nuclear black market emanating from Pakistan, helping the U.S. in collaboration with the IAEA to shut it down. (Salama 2004)

\section{$\underline{\text { Present Status }}$}

Libya's current nuclear program focuses mainly on research for the future application of nuclear techniques in the areas of desalination, agriculture, and nuclear medicine. The country also hopes to build a nuclear power plant for electricity generation, though such plans are likely not to come to fruition for many years.

To begin the process of regenerating Libya's former nuclear program for civilian, peaceful purposes, previous facilities have been redesigned to reflect public policy changes. The TNRC website states that,

"Late in 2003 TNRC was combined with two other Research Centers (The Water Desalination \& Treatment Research Center and Solar Studies Center) under the name of Renewable Energies and Water Desalination Research Center (REWDRC) with [the aim to unify and to conduct] studies \& research in the field[s] of :

- Peaceful Application of Nuclear Technology.

- Applied Renewable Energy Technology.

- Use of Desalination \& Treatment Technology.

- Provide Scientific \& Technical Services of specialty.

- Support the Educational Sectors." 294

Under an IAEA Technical Cooperation project, in association with the NNSA, the facility is redesigning the IRT-1 reactor to use low-enriched uranium, rather than high-enriched uranium, as fuel for conducting its research.

Because of Libya's limited water resources, water desalination is among the most appealing applications of nuclear technology, and appears to be in Libya's nuclear plans. Demand for fresh water in the mostly desert terrain of Libya greatly exceeds supply. In the 1950's and 1960's, during the process of oil exploration in southern Libya, great underground aquifers were found underneath the Sahara desert. In order to provide water to the vast majority of the population, who live along the Mediterranean coast, the Great

\footnotetext{
${ }^{293}$ Salama, Sammy. "Was Libyan WMD Disarmament a Significant Success for Nonproliferation?" Center for Nonproliferation Studies, Monterey Institute of International Studies. September 2004. Accessed 1 May 2007. http://www.nti.org/e_research/e3_56a.html

${ }^{294}$ Tajoura Nuclear Research Centre, "About the Centre.” http://www.tnrc.org. [edited for clarity]
} 
Manmade River Project (GMRP) was developed to pump and to transport up to 6 million cubic meters of water daily in "the world's largest and most expensive groundwater pumping and conveyance project." 295 GMRP consists of pipes, pumps, and reservoirs assembled in blowing sand at temperatures in excess of $50^{\circ} \mathrm{C}\left(122^{\circ} \mathrm{F}\right)$. Construction began in 1984, and the first water arrived in Tripoli in 1996; when completed it is expected to cost $\$ 25$ billion. ${ }^{296,297}$

Libya's primary agricultural water source remains the GMRP, but significant resources are being invested in desalinization research to meet growing water demands (See Appendix Q).

As Libya investigates prospects for nuclear desalination, the country has also signed an accord with France for aid on civil nuclear technologies in the areas of nuclear agriculture, health, and possible nuclear desalination. France agreed in 2006 to cooperate with Libya with the possibility of supporting a nuclear plant for water desalination. ${ }^{298}$ Under this plan, the Tajoura reactor would be adapted into a "nuclear desalination demonstration pilot plant using the hybrid RO-MED system." "299 However, in a cost analysis study of Libya's investments in desalination and groundwater pumping, Professor Daniel Loucks of Cornell University found that, "Desalination does not appear to be an economically efficient alternative to the groundwater system, the 'Great Manmade River Project.' ",300 Libya continues to conduct feasibility and cost-benefit studies, but has not carried out any further activity on this issue.

In March 2007 some confusion emerged regarding whether the U.S. had plans to assist Libya in building a nuclear power plant, due to apparently conflicting reports between Libyan news media and US officials. Libya's official JANA news agency reported that the Libyan parliament authorized its Foreign Liaison and International Cooperation Division to sign foreign agreements regarding nuclear plans, and implied that the division was prepared to sign a Libyan-American agreement aiming to establish a nuclear station in Libya for electricity production, water desalination, and nuclear medicine research. The agreement would include a provision for Libyan students to receive training in nuclear technology in the U.S., as well as the establishment of a regional center for nuclear medicine in Libya. ${ }^{301}$ US officials reported, however, that the United States was close to reaching an agreement with Libya for cooperation on a nuclear medicine center but for now has no plans for the kind of broad nuclear energy

\footnotetext{
${ }^{295}$ Loucks, Daniel P. “The Great Man-Made River in Libya, Does it Make Sense?” The Third Annual D.R.F. Harleman Honorary Lecture in Environmental Fluid Mechanics, 5 November 2004. Accessed 30 April 2007. http://www.engr.psu.edu/CE/Divisions/Hydro/seminars/Harleman04.pdf 296 Ibid.

${ }^{297}$ Great Man-Made River Authority, http://www.gmmra.org/

${ }^{298}$ Braithwaite, Tom. "Paris signs nuclear deal with Libya," Financial Times, Paris: 7 March 2006.

${ }^{299}$ International Nuclear Desalination Advisory Group. "Recent Activities in Nuclear Desalination in Member States,” INDAG Newsletter, No. 6, September 2006. Accessed 30 April 2007. http://www-pub.iaea.org/MTCD/publications/PDF/Newsletters/INDAG-NL-6.pdf

${ }^{300}$ Loucks, Daniel P. “The Great Man-Made River in Libya, Does it Make Sense?” The Third Annual D.R.F. Harleman Honorary Lecture in Environmental Fluid Mechanics, 5 November 2004. Accessed 30 April 2007. http://www.engr.psu.edu/CE/Divisions/Hydro/seminars/Harleman04.pdf

301 "Libya may ask for US help on nuclear power," Middle East Online, 13 March 2007. Accessed 30 April 2007. http://www.middle-east-online.com/ENGLISH/?id=19974
} 
development Tripoli suggested. ${ }^{302}$ A day later, State Department spokesman, Tom Casey, clarified that the U.S. had been discussing an agreement for the development of such a nuclear medicine research center with the Libyans, but "There's no formal pending nuclear cooperation agreement with Libya on nuclear power plants or any broader nuclear issues nor has the United States tabled a draft of any kind of agreement like that." He noted that since 2003, the U.S. has had "a number of scientific cooperation activities with the Libyans and that includes in the area of nuclear medicine and radioisotope productions" as part of a "broader effort to normalize relations."303 Libya's foreign ministry was authorized to enter into future negotiations on civil nuclear issues, but no such agreement had yet been forthcoming, save for discussions regarding the future development of the nuclear medicine center.

At present, Libya's short-term nuclear intentions seem to be limited to research and development for educational purposes, with the longer term purpose of building a nuclear power plant for desalination and electricity.

\section{ECONOMIC}

\section{Electricity}

Libya produces 19.44 billion $\mathrm{kWh}$ and consumes 18.08 billion $\mathrm{kWh}$ of electricity annually. ${ }^{304}$ Libya does not import or export electricity. The Ministry of Energy plans to develop the capability to export electricity to Europe, stating the opinion that, "In the future, exporting electricity will be a much more coveted resource and activity than either oil or gas. We are still carrying out a feasibility study in this regard." ${ }^{, 305}$ Almost all of Libya's electricity is produced from thermal plants, but the Ministry also is conducting pilot projects on renewable energy resources, with the goal of generating $6 \%$ of their electricity from renewable sources. In this regard, studies are focused chiefly on solar power, though hydrogen and wind power have also been considered. In 2004, Libya generated 6,341 GWh of electricity using the renewable resource of biomass. ${ }^{306}$

Changes in demand for electricity have varied widely over the past several years, averaging an increase of $6.4 \%$ annually for 2001-2006, but ranging from $4 \%$ in 2003 to almost $11 \%$ in $2005 .{ }^{307}$ Plans for future electricity output must also account for the high population growth rate of $2.3 \% .^{308}$

\footnotetext{
${ }^{302}$ Giacomo, Carol. "U.S., Libya negotiating nuclear medicine project,” Reuters, Alertnet, 12 March 2007. Accessed 30 April 2007. http://www.alertnet.org/thenews/newsdesk/L12435303.htm

${ }^{303} \mathrm{http}: / / w w w . s t a t e . g o v / \mathrm{r} / \mathrm{pa} / \mathrm{ei} /$ mideastdigest/81699.htm

${ }^{304}$ Central Intelligence Agency. "Libya," The World Factbook. Last updated 17 April, 2007. Accessed 25 April 2007. https://www.cia.gov/library/publications/the-world-factbook/geos/ly.html

${ }^{305} \mathrm{http}$ ://www.unitedworld-usa.com/reports/libya/interview03.asp

${ }^{306}$ International Energy Agency. "Renewables in Libya in 2004", IEA Statistics. http://www.iea.org/Textbase/stats/renewdata.asp?COUNTRY_CODE=LY

${ }^{307}$ General Electric Company of Libya. "Annual Statistics 2005." http://gecol.ly/en/stats/English\%20Staistic\%202005.pdf

${ }^{308}$ Central Intelligence Agency. "Libya," The World Factbook. Last updated 17 April, 2007. Accessed 25 April 2007. https://www.cia.gov/library/publications/the-world-factbook/geos/ly.html
} 


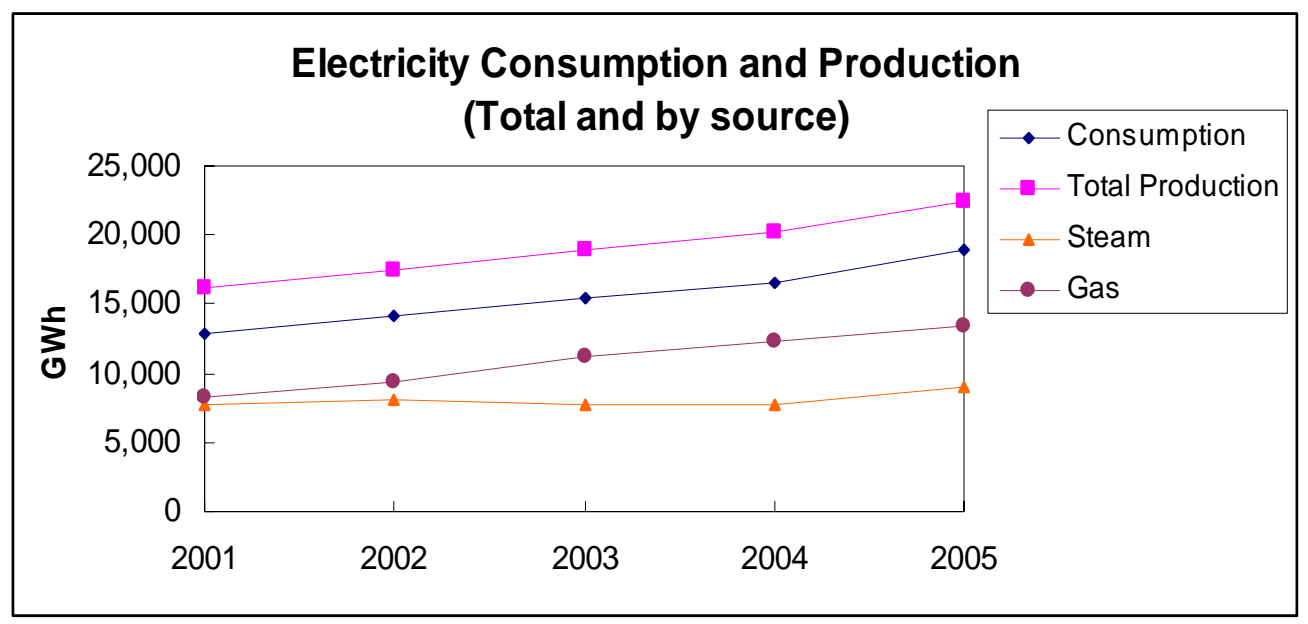

Figure 2. Evolution of Libya's Electricity Consumption and Production. ${ }^{309}$

Libya collaborates on electricity resources with several neighboring countries. Libya's electric transmission grid was connected with that of Egypt in $1999,{ }^{310}$ and Egypt established interconnection with the electric grids of Syria, Jordan, and Lebanon in 2002. Construction for a connection with Turkey's grid was completed in 2003, but as of March 2007 it was unclear when it would become online. ${ }^{311}$

Note: Spain and Turkey (via Bulgaria) are connected to the European UTCE system

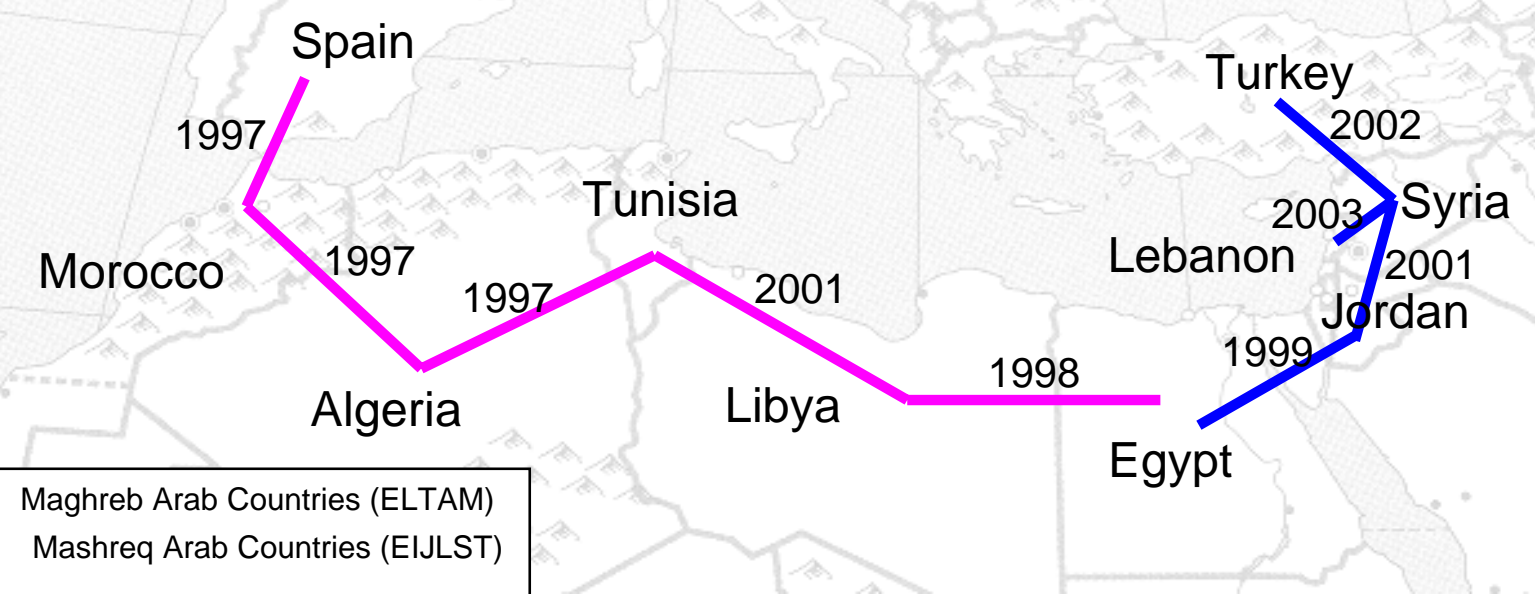

Figure 3. Interconnection of Electric Transmission Grids in the Middle East and North Africa. ${ }^{312}$

\footnotetext{
${ }^{309}$ General Electric Company of Libya. "Annual Statistics 2005." http://gecol.ly/en/stats/English\%20Staistic\%202005.pdf

310 Javendanfar, Meir. "Egypt-Opportunities." The Middle East Economic and Political Analysis Company. Accessed 5 April 2007. http://www.meepas.com/egyptopportunitiespart1.htm

311 "Transmission Grid Network: The seven wonders of interconnection", Middle East Energy, March 2007. Accessed 21 May 2007.

http://pepei.pennnet.com/display_article/288634/89/ARTCL/none/none/Transmission-Grid-Network:-Theseven-wonders-of-interconnection/

312 "The Potential for Regionally Integrated Energy Development in Africa”, World Energy Council 2007. Accessed 21 May 2007. Dates shown are as listed in this source, which are likely dates when construction began. Other sources list various other dates of completion of construction, or when the grids came online. http://www.worldenergy.org/wec-geis/publications/reports/africa/cooperation/cooperation.asp
} 
Oil

Libya's vast oil reserves contain a proven 42 billion bbl, which is $3 \%$ of the world's oil reserves and the largest reserves in Africa. Libya produces 1.72 million bbl per day and consumes $237,000 \mathrm{bbl}$ per day, less than $15 \%$ of production. Most of Libya's oil produced, 1.34 million bbl per day, is exported; Libya does not import oil. ${ }^{313}$

Discovery of oil in 1959 brought significant wealth to a previously poor country, but it did not affect all the population. "The government dominates Libya's socialistoriented economy through complete control of the country's oil resources," the US Department of State comments, later continuing: "Much of the country's income has been lost to waste, corruption, conventional armaments purchases, and attempts to develop weapons of mass destruction." 314 Oil resources account for approximately 97\% of export earnings and 54\% of the gross domestic product. The US Department of Energy states that, "Libya is hoping to reduce its dependency on oil as the country's sole source of income;" "315 nevertheless, the Ministry of Energy has set a goal of nearly doubling oil production to 3 billion bbl per day by $2010 .^{316}$

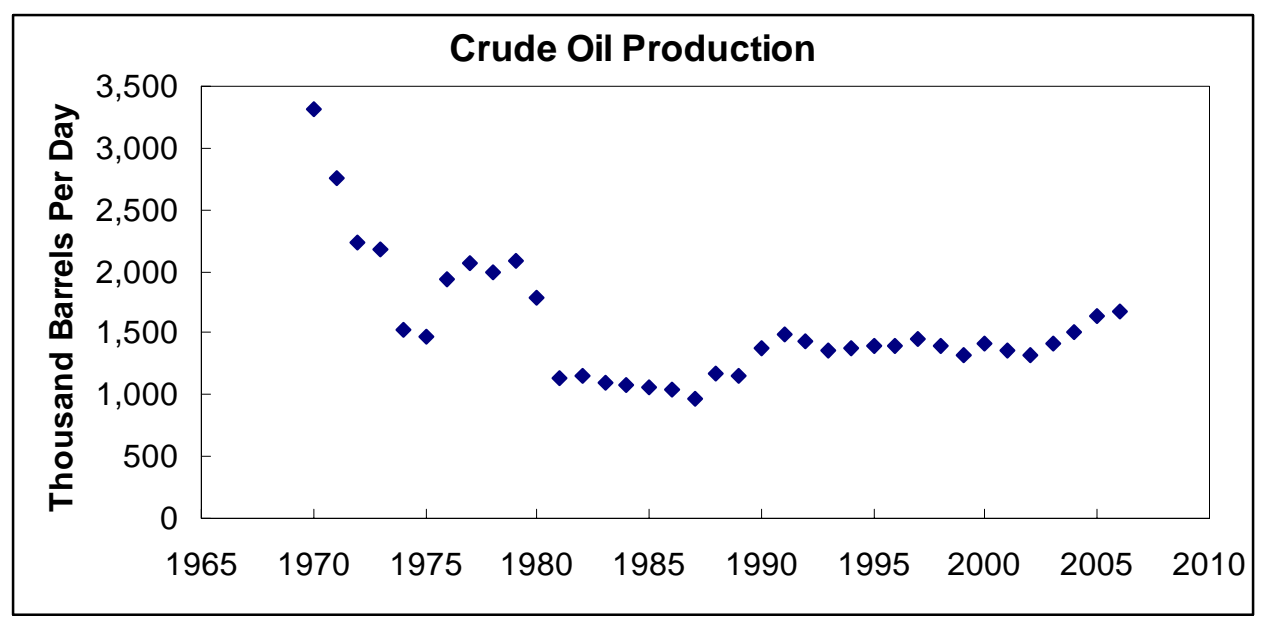

Figure 4. Evolution of Libya's Crude Oil Production; note the effect of US and UN embargoes. ${ }^{317}$

\footnotetext{
${ }^{313}$ Central Intelligence Agency. "Libya," The World Factbook. Last updated 17 April, 2007. Accessed 25 April 2007. https://www.cia.gov/library/publications/the-world-factbook/geos/ly.html

${ }^{314}$ Bureau of Near Eastern Affairs. "Background Note: Libya," U.S. Department of State, February 2007. Accessed 25 April 2007. http://www.state.gov/r/pa/ei/bgn/5425.htm

${ }^{315}$ Energy Information Administration. "Libya: Background", Country Analysis Briefs, U.S. Department of Energy, March 2006. http://www.eia.doe.gov/emeu/cabs/Libya/Background.html

316 "Interview with Dr. Marhi Ben-Shatwan, Minister of Energy." United World, 16 January 2006. http://www.unitedworld-usa.com/reports/libya/interview03.asp

${ }^{317}$ Energy Information Administration. "World Crude Oil Production (Including Lease Condensate), 19702006," International Petroleum Monthly, March 2007. Posted 5 April 2007. Accessed 30 April 2007. http://www.eia.doe.gov/emeu/ipsr/t41b.xls
} 


\section{Natural Gas}

Libya produces 8.06 billion cubic meters of natural gas annually, of which 2.13 billion cubic meters are exported and 5.93 billion cu $\mathrm{m}$ are consumed domestically. Libya does not import natural gas. Proven reserves amount to 1.47 trillion cubic meters, which at the current rate could last Libya for 182 years. Libya seeks to produce more natural gas, as it will enable more oil to be exported and itself can be a commodity for export. $^{318}$

In summary, Libya's oil and gas resources are more than sufficient to meet all of Libya's energy needs for the foreseeable future. Libya intends to promote export of these goods for greater income to improve and to stabilize its economy, as well as to investigate renewable resource options.

\section{INTERNATIONAL TERATY COMMITMENTS AND IAEA COOPERATION}

\section{IAEA Membership and International Treaty Commitments}

Libya became a member of the IAEA in 1963, and has since signed and ratified several international agreements. Libya became a party to the Treaty on the NonProliferation of Nuclear Weapons (NPT) on 26 May 1975, and its Safeguards Agreement pursuant to the NPT entered into force on 8 July 1980. Libya's Additional Protocol to the Safeguards Agreement entered into force in August 2006. Libya signed the Limited (Partial) Test Ban Treaty in 1963 and ratified it in 1968; it signed the Comprehensive Test Ban Treaty in November 2001 and ratified it in January 2004. ${ }^{319,320,321,322}$

In 1971, Libya signed the 1925 Geneva Protocol, with the caveat that it would only be bound to the agreement provided that other signatory countries did not pose a threat to Libyan sovereignty. ${ }^{323}$ Libya then signed the Biological and Toxic Weapons Convention (BTWC) without reservations in 1982, but reportedly continued pursuing a clandestine BW program.

\footnotetext{
${ }^{318}$ Arab-British Trade. "New Possibilities in Libya", Times Publications Ltd, London: 1999. http://www.times-

publications.com/publications/times_articles/corporate_africa_summer1999/new_possibilities 1.htm

${ }^{319}$ International Atomic Energy Agency. "Implementation of the NPT Safeguards Agreement of the Socialist People's Libyan Arab Jamahiriya," 20 February 2004. GOV/2004/12. Accessed 11 May 2007. http://www.iaea.org/Publications/Documents/Board/2004/gov2004-12.pdf

${ }^{320}$ International Atomic Energy Agency. "Strengthened Safeguards System: Status of Additional Protocols," 22 March 2007. Accessed 30 April 2007. http://www.iaea.org/OurWork/SV/Safeguards/sg_protocol.html

${ }^{321}$ Bureau of Verification, Compliance, and Implementation, U.S. Department of State. "Treaty Banning Nuclear Weapon Tests in the Atmosphere, in Outer Space, and Under Water.” Accessed 30 April 2007. http://www.state.gov/t/ac/trt/4797.htm\#signatory

${ }^{322}$ CTBTO Preparatory Commission. "Status of Signature and Ratification." 2007. Accessed 30 April 2007. http://www.ctbto.org

${ }^{323}$ Nuclear Threat Initiative. "Libya Profile: Biological Overview," Center for Nonproliferation Studies, Monterey Institute of International Studies. Updated 2006. Accessed 27 April 2007. http://www.nti.org/e_research/profiles/Libya/3941.html
} 
The US Department of State notes that, "Since its renunciation of its WMD program in December 2003, Libya has cooperated with the U.S., the U.K., the International Atomic Energy Agency, and the Organization for the Prohibition of Chemical Weapons" towards ridding itself of weapons of mass destruction. ${ }^{324}$ Libya has also since joined the Chemical Weapons Convention.

Libya has established a very minimal legal framework for nuclear energy development; it seems inadequate even for general research and development. Among important agreements to which Libya has not yet acceded are those regarding the privileges and immunities of the IAEA, civil liability for nuclear damage, spent fuel and waste management, and the Convention on Nuclear Safety. For a full list of Libya's commitments to multilateral conventions and safeguards agreements with the IAEA, see Appendix H.

\section{IAEA Technical Cooperation Projects}

Libya is involved in 10 national Technical Cooperation (TC) projects, 36 regional projects, and 4 interregional projects. ${ }^{325}$ Prior to the about-face of Libya's nuclear policy in 2003, the IAEA conducted Technical Cooperation projects with Libya in strengthening the basic infrastructure for research and development in nuclear science and technology. Primary areas of focus included radiopharmaceutical applications, spectrometry and neutron activation analysis, strengthening of a dosimetry laboratory, radioactive contamination assessment of foodstuffs, and improvement of livestock production. ${ }^{326}$ In the period from 2003 to 2004, the TC program centered focus on the areas of human health, water, agriculture, nuclear analytical techniques, and research reactor safety. Particular attention was given to nuclear medicine and radiation therapy services, isotope hydrology for improved groundwater resources management, and the establishment of a drip irrigation system using nuclear techniques. Other activities included enhancing the safety system of Tajoura research reactor and critical facility, food analysis, and pollution monitoring.

The current TC program maintains focus on continuing activities related to nuclear medicine and radiation therapy, the safety system of TNRC, and human resource development. The new program includes simulation of nuclear seawater desalination processes, spent fuel and waste management, sustainable energy and nuclear power planning, and the strengthening of the national radiation protection infrastructure. TC project LIB/4/009, 'Enhancement of the Safety System of Tajoura Research Reactor and Critical Facility', was first approved in 2003, and seeks to replace the reactor's use of HEU with LEU.

Thus, TC programs have recently supported research and development in human health, agriculture, and water resources, and are working on increasing the research reactor's safety system to minimize proliferation risks.

\footnotetext{
${ }^{324}$ Bureau of Near Eastern Affairs. "Background Note: Libya," U.S. Department of State, February 2007. Accessed 25 April 2007. http://www.state.gov/r/pa/ei/bgn/5425.htm

${ }^{325}$ International Atomic Energy Agency. "Information Records on Libyan Arab Jamahiriya," 2005. Accessed 30 April 2007. http://www-tc.iaea.org/tcweb/regionalsites/africa/country/default.asp?cid=LIB

${ }^{326}$ International Atomic Energy Agency. "Country Overview for the Libyan Arab Jamahiriya," 2005. Accessed 30 April 2007. http://www-tc.iaea.org/tcweb/regionalsites/africa/documents/LIB2005.pdf
} 


\section{REGIONAL PROJECT POSSIBILITIES}

Should Libya demonstrate a need for an alternative energy source, improve its nuclear infrastructure, and continue to adhere to nuclear conventions and agreements, it could perhaps contribute to a regional nuclear project in Africa. The U.K.'s Foreign and Commonwealth Office comments that, "Africa has occupied a central position in Libyan foreign policy for some years." 327 Libya has provided significant support for the Organisation for African Unity and its successor organization, the African Union. Qadhafi has called repeatedly for Arab unity, believing it is not just an ideal but rather a realistic goal. ${ }^{328}$

Some regional tensions have complicated Libya's international relations in the past few decades, including a brief border war with Egypt in 1977 originating from Libyan protests of Egyptian ties with Israel. In the 1980's, Libya's relations with Tunisia were tense due to maritime border conflicts and expulsion of Tunisian workers from Libya. Relations with Morocco have historically been strained, as revolutionary Libyan ideals differ significantly from the moderate, monarchist, pro-Western Moroccan perspective. Libya's closest neighbor diplomatically has been Algeria. ${ }^{329}$ Possible collaboration options could include funding Egyptian nuclear programs, in return for a commodity presently required: fresh water. Water could be transported from Egypt's planned nuclear desalination plant on the Mediterranean to Libya's most populated areas through a pipe system similar to that currently in process for the GMRP. Libya could also benefit from its Arab neighbors' nuclear regulatory systems, collaborate on knowledge management and training, and join with the international community to establish a stronger nuclear infrastructure prior to further nuclear development.

\footnotetext{
${ }^{327}$ Foreign and Commonwealth Office. "Country Profiles: Libya”, Countries \& Regions. Last updated January 2007. Accessed 2 May 2007. http://www.fco.gov.uk

${ }^{328}$ Metz, Helen Chapin, ed. Libya: A Country Study. Washington: GPO for the Library of Congress, 1987. Accessed 2 May 2007.http://countrystudies.us/libya/32.htm

${ }^{329}$ Metz, Helen Chapin, ed. Libya: A Country Study. Washington: GPO for the Library of Congress, 1987. Accessed 2 May 2007. http://countrystudies.us/libya/84.htm
} 


\section{SAUDI ARABIA}

Overview

The birthplace of Islam, Saudi Arabia is home to the religion's two holiest cities, Mecca and Medina. Saudi Arabia is the world's leading producer of petroleum and holds about $25 \%$ of the world's proven oil reserves. Ranked $14^{\text {th }}$ of countries by land area and $44^{\text {th }}$ in the world by population, Saudi Arabia is home to 27.6 million people, including over 5.5 million foreign workers. Until the 1960's, most of the population was either nomadic or semi-nomadic; due to rapid economic and urban growth, more than $95 \%$ of the population is now settled. Most Saudis are Arab, and Islam is the official state religion; the law requires that all citizens be Muslims.

Saudi Arabia's oil-based economy, which is subject to strong governmental controls, made possible rapid economic development that increased the standard of living of most Saudis. With a nominal GDP per capita of $\$ 13,800$ compared to the world average of $\$ 10,000$, Saudi Arabia ranks $73^{\text {rd }}$ in the world. Saudi Arabia's per capita energy consumption is about $5,232 \mathrm{kWh}$, which is much lower than $12,454 \mathrm{kWh}$ in the U.S., but it is high for the Middle East and greater than the world average of 2,962 $\mathrm{kWh}$. Less than $2 \%$ of Saudi Arabia's land is arable, but to alleviate dependence on oil revenues alone, the Saudi government has encouraged agriculture and industry by promoting private sector and foreign investment, as well as other means of economic reform and diversification. In this regard, Saudi Arabia acceded to the World Trade Organization (WTO) in 2005 after a series of negotiations. Saudi Arabia has promised billions of dollars of economic aid to neighboring Arab countries, and its domestic population includes over 240,000 Palestinian refugees. ${ }^{330,331}$

Ongoing governmental concerns also include a burgeoning population, minimal fresh water resources, and terrorism. Environmental concerns regarding desertification, depletion of underground water resources, and the lack of permanent fresh water bodies have prompted the development of extensive seawater desalination facilities.

Saudi Arabia is $5^{\text {th }}$ in the world for military spending as a percent GDP at $10 \%$. Saudi Arabia has suffered terrorist bombings in May and November 2003; these were primarily targeted at foreign workers living in the country. (CIA Factbook 2007)

Saudi Arabia has extensive domestic energy resources, but few potable water resources. Its primary interest in nuclear applications is nuclear desalination, as a more environmentally friendly and efficient solution for water production. However, Saudi Arabia lacks technical capability to implement a sophisticated nuclear program, and has inadequate legislative and regulatory infrastructure needed for the development of such a program. The country could collaborate with Egypt, learning from Egypt's infrastructure and technology, while financing further research and development especially in nuclear desalination. Saudi Arabia already intends to collaborate with the other Gulf Cooperation Council (GCC) members to research nuclear energy and desalination for peaceful purposes in the region.

\footnotetext{
${ }^{330}$ Central Intelligence Agency. "Saudi Arabia," The World Factbook. Last updated 17 April 2007. Accessed 2 May 2007. https:/www.cia.gov/library/publications/the-world-factbook/geos/sa.html ${ }^{331}$ Bureau of Near Eastern Affairs. "Background Note: Saudi Arabia," U.S. Department of State, October 2006. Accessed 2 May 2007. http://www.state.gov/r/pa/ei/bgn/3584.htm
} 


\title{
1. NUCLEAR INFRASTRUCTURE/INTENTIONS
}

\author{
Infrastructure
}

Knowledge management

Saudi Arabia has been working to develop its domestic industry in the past several years, and currently $25 \%$ of its population works in industry. Nonetheless, the unemployment rate has been estimated between $13 \%$ and $25 \%$ in Saudi males. The country's literacy rates are high for the Middle East, with an overall literacy rate of $78.8 \%$ of the population age 15 and over who can read and write, but this belies the disparity of literacy rates between males and females ( $84.7 \%$ and $70.8 \%$, respectively). (CIA Factbook 2007)

Saudi research scientists have collaborated on nuclear research, reactor operation, isotope analysis, and radiation protection with countries as diverse as China, Pakistan, Iraq, Jordan, Germany, Switzerland, and the United States. ${ }^{332}$ Still, nuclear technology capability seems quite limited in Saudi Arabia. Defense and security analysts Wyn Bowen and Joanna Kidd of King's College London assert, "The Kingdom does not appear to possess the necessary technical infrastructure to develop [a nuclear weapon] indigenously, bar significant infusions of external assistance." ${ }^{333}$ The Stockholm International Peace Research Institute states that, "Open sources suggest that Saudi Arabia lacks significant experience with the nuclear fuel cycle to develop an advanced nuclear programme. It appears that both technical know-how and practical experience are missing." 334 Despite small-scale nuclear research, the Saudis have not yet developed a thorough nuclear program.

Some research is being conducted in the university system and research centers. Engineering and physics departments at the following universities have participated in nuclear research: King Fahd University of Petroleum and Minerals, King Faisal University, Umm Al-Qura University, King Abdulaziz University, King Saud University, and Riyadh University. ${ }^{335}$ Most research is conducted at King Abdulaziz University in Jeddah, where the Department of Nuclear Engineering was established in 1977 for the peaceful applications of nuclear energy. The Undergraduate program emphasizes nuclear reactor engineering, radiation protection, and isotope application engineering, and this education is applied in fields of energy, industry, medicine, and agriculture. The facilities of the university include laboratories for radiation detection, health physics, radioisotope application, and nuclear computation and reactor simulation. Capabilities of these facilities include X-ray, gamma, and neutron radiography, a radioanalysis

\footnotetext{
332 Stockholm International Peace Research Institute. "Saudi Arabia Country Profile," Countries of Strategic Nuclear Concern, July 2004. Accessed 4 May 2007. http://www.sipri.org/contents/expcon/cnsc3sau.html

${ }^{333}$ Bowen, Wyn Q. and Joanna Kidd. "The Nuclear Capabilities and Ambitions of Iran's Neighbors", Getting Ready for a Nuclear-Ready Iran. Henri Sokolski and Patrick Clawson, ed. Strategic Studies Institute, October 2005. Accessed 4 May 2007. p. 51-88. http://www.strategicstudiesinstitute.army.mil/pdffiles/pub629.pdf

${ }^{334}$ Stockholm International Peace Research Institute. "Saudi Arabia Country Profile," Countries of Strategic Nuclear Concern, July 2004. Accessed 4 May 2007. http://www.sipri.org/contents/expcon/cnsc3sau.html 335 Ibid.
} 
laboratory for trace element analysis using an X-ray fluorescence analyzer and an atomic absorption spectrometer, and a nondestructive testing laboratory using radiation for detection of minute cracks, flaws, corrosion, and welding defects in materials. ${ }^{336}$

King Abdulaziz City for Science and Technology (KACST), which defines itself as "an independent scientific organization of the Saudi Arabian Government," 337 directs research on petroleum, astronomy and geophysics, electronics, alternative energy sources, and resources and the environment. KACST includes an Institute of Atomic Energy Research and an Energy Research Institute.

The Institute of Atomic Energy Research is described as follows:

"The Atomic Energy Research Institute (AERI) was established within KACST in 1988 with the aim of adapting the nuclear sciences and technologies and utilizing them 'in support of the economic, industrial and agricultural plans of the Kingdom.' The objectives of AERI include drafting a national atomic energy plan and supervising its implementation; conducting research in the field of nuclear technologies; identifying manpower requirements in the area of atomic energy research; and training and developing manpower in the area of atomic energy research." 338

The institute has several departments: a Radiation Protection Department, an Industrial Applications Department, a Nuclear Reactor and Safety Department, and a Materials Department. AERI has programs that focus on industrial applications of radiation and radioactive isotopes, nuclear power and reactors, nuclear materials, and radiation protection. (Bowen and Kidd 2005)

KACST's Energy Research Institute aims "To become the leading national research institute in energy related issues." It conducts research in the areas of "resources development and utilization of both conventional energy (oil, gas, coal) and renewable energy (solar, wind, geothermal, hydrogen etc.)." The Institute identifies its main efforts as adapting and producing energy-related technologies, creating practical solutions to reduce energy waste, producing national databases of renewable energy resources, researching the energy efficient provision of basic needs in remote areas, and studying the environmental impact of different energy sources. ${ }^{339}$

Two other research facilities are of note. A 3MV General Ionex Tandetron Accelerator is located at the Energy Research Laboratory of King Fahn University of Petroleum and Minerals. It is used for academic research on ion beam techniques, nuclear physics experiments, and nuclear reaction analysis. Second, the Cyclotron CS-30

\footnotetext{
${ }^{336}$ Department of Nuclear Engineering, King Abdulaziz University. http://engg.kaau.edu.sa/main/HomePage/Departments/NE/NE.html

${ }^{337}$ King Abdulaziz City for Science and Technology. http://www.kacst.edu.sa/eng/aboutus.php

${ }^{338}$ Bowen, Wyn Q. and Joanna Kidd. "The Nuclear Capabilities and Ambitions of Iran's Neighbors", Getting Ready for a Nuclear-Ready Iran. Henri Sokolski and Patrick Clawson, ed. Strategic Studies Institute, October 2005. Accessed 4 May 2007. p. 51-88. http://www.strategicstudiesinstitute.army.mil/pdffiles/pub629.pdf

${ }^{339}$ Energy Research Institute. http://www.kacst.edu.sa/eng/inst/eri/index.php
} 
of King Faisal Specialist Hospital and Research Center in Riyadh became operational in 1983 and was designed for isotope production. ${ }^{340}$

Research topics of published papers and conference presentations have included advanced nuclear fuel production, research on advanced reactors, thermal neutron flux studies, nuclear desalination, siting of nuclear power plants, planning a nuclear R\&D program, determination of the uranium content of Egyptian phosphate ores, nuclear safety, and neutron activation analysis. Research with possible weapons applications, according to the Federation of American Scientists, has included studies on the radiation protection and shielding capacity of sand and asphalt against fast neutron sources (fusion neutrons), and the susceptibility of satellites to an electromagnetic pulse. ${ }^{341}$ (Gorwitz 2005)

\section{Uranium Resources}

Saudi Arabia does not have any significant identified uranium deposits. Though low-level amounts of uranium and thorium have been found in the Tabuk basin, they have not yet been mined. However, considerable phosphate resources have been uncovered and mined. ${ }^{342}$ Uranium can be extracted from phosphates using a technology first developed by the Atomic Energy Commission in the $1950 \mathrm{~s}$, in which $\mathrm{U}_{3} \mathrm{O}_{8}$ is extracted, converted into $\mathrm{UF}_{6}$, enriched, and eventually manufactured into pellets used for fuel rods in nuclear power reactors. ${ }^{343}$ This process is more expensive than mining natural uranium, but it can be more attractive politically than obtaining uranium from an international source. Academic research has been conducted on "The Separation and Determination of Rare Earths in Phosphate Deposits from the North of the Kingdom of Saudi Arabia," 344 but no further work was found in documents surveyed for this study.

\section{Nuclear Reactors and Fuel Facilities}

Saudi Arabia does not currently have any nuclear power or research reactors; it also does not have any known conversion, enrichment, or fuel fabrication facilities. ${ }^{345}$

Concerning reprocessing capabilities, the Stockholm International Peace Research Institute states,

\footnotetext{
${ }^{340}$ Stockholm International Peace Research Institute. "Saudi Arabia Country Profile," Countries of Strategic Nuclear Concern, July 2004. Accessed 4 May 2007. http://www.sipri.org/contents/expcon/cnsc3sau.html

${ }^{341}$ Gorwitz, Mark. "Saudi Arabian Nuclear Science Bibliography: Open Literature Citations", May 2005. Accessed 4 May 2007. http://www.fas.org/nuke/guide/saudi/biblio.pdf

${ }^{342}$ Stockholm International Peace Research Institute. "Saudi Arabia Country Profile", Countries of Strategic Nuclear Concern, July 2004. Accessed 3 May 2007. http://www.sipri.org/contents/expcon/cnsc3sau.html

${ }^{343}$ Talbot, Stephen. "Westinghouse backs King Hassan’s Desert War.” Multinational Monitor, Vol. 1 No. 10, November 1980. Accessed 23 April 2007. http://multinationalmonitor.org/hyper/issues/1980/11/talbot.html

${ }^{344}$ Bowen, Wyn Q. and Joanna Kidd. "The Nuclear Capabilities and Ambitions of Iran's Neighbors", Getting Ready for a Nuclear-Ready Iran. Henri Sokolski and Patrick Clawson, ed. Strategic Studies Institute, October 2005. Accessed 4 May 2007. p. 51-88. http://www.strategicstudiesinstitute.army.mil/pdffiles/pub629.pdf

${ }^{345}$ Stockholm International Peace Research Institute. "Saudi Arabia Country Profile," Countries of Strategic Nuclear Concern, July 2004. Accessed 4 May 2007. http://www.sipri.org/contents/expcon/cnsc3sau.html
} 
"Saudi Arabia has no known reprocessing activities underway. However, the Atomic Energy Research Institute supports several laboratories, which might be capable of conducting reprocessing activities including the 'physical separation lab,' a 'chemical separation lab,' and a 'radio chemical lab.' Open sources do not enumerate specific research conducted in those laboratories."

Bowen and Kidd concur, "Although Saudi Arabia does not appear to possess a reprocessing capability, the AERI has four laboratories of potential relevance in this field," adding a radioactive isotopes and chemical separation facility to the list of three laboratories above. The AERI website was unavailable for independent verification.

Minimal waste management facilities are required, because little radioactive waste is generated from the nuclear laboratory experiments. However, scientists from the Nuclear Engineering and Civil Engineering Departments of King Abdulaziz University designed and built a temporary storage structure to hold radioactive waste from research work and medical uses of radioisotopes produced from various university research. ${ }^{347}$

According to one source, Saudi Arabia opened a nuclear research center at the secret desert military complex at Al-Suleiyel, near Al-Kharj, in 1975. Currently this location is reported to house CSS-2 nuclear-capable intermediaterange missiles. Saudi Arabia purchased between 50 and 60 of these missiles, now largely considered obsolete, from China in $1998 .^{348,349}$

\section{Regulation}

All of the IAEA's current Technical Cooperation projects are conducted in partnership with KACST or with King Faisal Specialist Hospital and Research Center. The information sources checked in this study do not clarify the nuclear regulatory responsibilities of the various Saudi government agencies.

\section{Intentions}

Saudi scientists have studied the viability of introducing nuclear power into the country since $1978 .{ }^{350}$ Research interests particularly focused on a low-power, dualpurpose nuclear plant for water desalination and electricity production, and these studies

\footnotetext{
${ }^{346}$ Stockholm International Peace Research Institute. "Saudi Arabia Country Profile," Countries of Strategic Nuclear Concern, July 2004. Accessed 4 May 2007. http://www.sipri.org/contents/expcon/cnsc3sau.html 347 Ibid.

348 Salama, Sammy and Heidi Weber. “The Emerging Arab Response to Iran's Unabated Nuclear Program", Nuclear Threat Initiative, 22 December 2006. Accessed 4 May 2007. http://www.nti.org/e_research/e3_83.html

${ }^{349}$ Pojedinec, Alex. "Saudi Nuclear Intentions and the IAEA Small Quantities Protocol", Center for Defense Information, 30 June 2005. Accessed 4 May 2007. http://www.cdi.org/program/document.cfm?DocumentID=3050\&from_page=../index.cfm

${ }^{350}$ International Atomic Energy Agency. "Nuclear Energy Planning", Technical Cooperation Project 1978. SAU/0/002. Accessed via http://www-tc.iaea.org/
} 
have "positively assessed" the feasibility of such a plant. ${ }^{351}$ Saudi Arabia has extremely limited fresh water resources, and fresh water is increasingly scarce as its underground aquifers are being depleted. Lester Brown writes in the Encyclopedia of the Earth,

"A 1984 Saudi national survey reported fossil water reserves at 462 billion tons. Half of that, Craig Smith [of the New York Times] reports, has probably disappeared by now. This suggests that irrigated agriculture could last for another decade or so and then will largely vanish, limited to the small area that can be irrigated with water from the shallow aquifers that are replenished by the kingdom's sparse rainfall.",352

The World Resources Institute estimates that from 1977-2001 Saudi Arabia maintained approximately two cubic kilometers of internal renewable water resources, which is very small compared to Iran's 128 cubic km; the countries are approximately equal in area. ${ }^{353}$ With a population growth of $2.06 \%$, demand for fresh water is continually increasing. ${ }^{354}$

Due to the limited fresh water supply, Saudi Arabia has turned to desalination to meet its fresh water needs. An entire department of King Abdulaziz University is focused on Thermal Engineering \& Desalination. Among the facilities of the department is a laboratory desalination plant capable of producing $137 \mathrm{~m}^{3}$ of fresh water per day. ${ }^{355}$ The Saline Water Conversion Corporation (SWCC) was established in 1974 to generate fresh water on a larger scale to supplement groundwater resources. As of 2001, SWCC had developed 27 desalination plants to produce 668 million gallons of desalinated water per day (MGD) and $4115 \mathrm{MW}$ of electricity, and an additional four plants were under construction for a combined total of 886 MGD desalinated water production and 5114 MW electrical power generation. ${ }^{356}$ This scale of thermal desalination is sufficient to meet about $70 \%$ of the country's drinking water needs, making Saudi Arabia the world's largest producer of desalinated water. More than 50 cities and distribution centers in Saudi Arabia receive their water from these plants. Water is heavily subsidized, costing US \$1.08 per cubic meter to produce but sold for only about three cents; so despite limited resources, per capita water consumption in Saudi Arabia is among the highest in

\footnotetext{
${ }^{351}$ Stockholm International Peace Research Institute. "Saudi Arabia Country Profile", Countries of Strategic Nuclear Concern, July 2004. Accessed 3 May 2007. http://www.sipri.org/contents/expcon/cnsc3sau.html

${ }^{352}$ Brown, Lester; Brian Black and Galal Hassan Galal Hussein, Eds. “Aquifer depletion.” Encyclopedia of Earth. Eds. Cutler J. Cleveland (Washington, D.C.: Environmental Information Coalition, National Council for Science and the Environment). First published 14 September 2006; Last revised 12 February 2007. Accessed 7 May 2007. http://www.eoearth.org/article/Aquifer_depletion

${ }^{353}$ World Resources Institute. "Water Resources and Freshwater Ecosystems: Country Profiles", 2006. Accessed 7 May 2007. http://earthtrends.wri.org/text/water-resources/country-profiles.html

${ }^{354}$ Central Intelligence Agency. "Saudi Arabia," The World Factbook. Last updated 17 April 2007. Accessed 2 May 2007. https:/www.cia.gov/library/publications/the-world-factbook/geos/sa.html

${ }^{355}$ Department Facilities and Laboratories, Faculty of Engineering, Thermal Engineering and Desalination Department. King Abdulaziz University. http://engg.kaau.edu.sa/MEP/facilities.htm

${ }^{356}$ Al-Sofi, Mohammed Abdul-Kareem. "Seawater desalination - SWCC experience and vision", International Journal of Nuclear Desalination, 2001. p121
} 
the world. ${ }^{357}$ Thus, increased investment and expansion of water desalination are among goals of the SWCC and are primary in government policies as well.

Extensive preliminary research has been conducted in Saudi academia on nuclear desalination, ${ }^{358}$ but such a plant has yet to be constructed. The IAEA lists no current Saudi Technical Cooperation projects on nuclear desalination, though a project completed in 1996 conducted a feasibility study on nuclear desalination of sea water in comparison with existing desalination plants (See Appendix Q). ${ }^{359}$

Yet serious Saudi interest in nuclear energy is quite new, as noted by David Sanger and William Broad in the New York Times:

"Two years ago, the leaders of Saudi Arabia told international atomic regulators that they could foresee no need for the kingdom to develop nuclear power. Today, they are scrambling to hire atomic contractors, buy nuclear hardware and build support for a regional system of reactors." 360

This significant new interest has led to speculation regarding Saudi intent for their nuclear program. Saudi Arabia has no confirmed evidence of a chemical or biological weapons program, and has called for the elimination of all nuclear, biological, and chemical weapons in the Middle East. ${ }^{361}$ In 2006, for instance, Foreign Minister Prince Saud al-Faisal told The Times that Saudi Arabia opposed the spread of nuclear power and weapons in the Arab world. ${ }^{362}$

The timing of Saudi nuclear interest may indicate unease over Iran's expanding nuclear program. In February 2006, Saudi Foreign Minister Saud al-Faisal criticized the potential weapon applications of Iran's uranium enrichment program, asking, "Where is Iran going to use these weapons? If their intention is to bomb Israel, they will kill Palestinians, Syrians, Jordanians, and Saudis, as well." 363 Indeed, Saudi Arabia has due cause for its rising security concerns. Since September 11, 2001, relations between Washington and Riyadh have cooled considerably, with U.S. security assurances to the nation correspondingly reduced. Combined with the lack of international pressure on Israel's nuclear arsenal, and Iran's nascent nuclear program with significant

\footnotetext{
${ }^{357}$ U.S. Commercial Service. "Water Resources Equipment: Saudi Arabia”, U.S. Department of Commerce, 2001-2007. Accessed 7 May 2007. http://www.buyusa.gov/saudiarabia/en/113.html

${ }^{358}$ See, for example, recent articles published in the International Journal of Nuclear Desalination: AlSofi, "Seawater desalination - SWCC experience and vision", 2001; Al-Mutaz, "Hybrid RO MSF: a practical option for nuclear desalination", 2003; Aljohani et. al., "The role of nuclear desalination in the Kingdom of Saudi Arabia", 2004; Aljohani et. al., "Siting of nuclear desalination plants in Saudi Arabia: a seismic study", 2005.

${ }^{359}$ International Atomic Energy Agency, “TC Projects by Country: Saudi Arabia.” Accessed 7 May 2007. http://www-tc.iaea.org/tcweb/tcprogramme/projectsbycountry/query/default.asp

${ }^{360}$ Broad, William J. and David E. Sanger. "With Eye on Iran, Rivals Also Want Nuclear Power", New York Times, 15 April 2007.

${ }^{361}$ Henderson, Simon. "Toward a Saudi Nuclear Option: The Saudi-Pakistani Summit", The Washington Institute PolicyWatch \#793, 16 October 2003. Accessed 4 May 2007. http://www.washingtoninstitute.org/templateC05.php?CID=1671

${ }^{362}$ Beeston, Richard. "Six Arab states join rush to go nuclear", Times Online, 4 November 2006. Accessed 4 May 2007. http://www.timesonline.co.uk/tol/news/world/middle_east/article624855.ece

${ }^{363}$ Salama, Sammy and Heidi Weber. "The Emerging Arab Response to Iran's Unabated Nuclear Program”, Nuclear Threat Initiative, 22 December 2006. Accessed 4 May 2007. http://www.nti.org/e_research/e3_83.html
} 
repercussions for Saudi security, these factors may cause Saudi Arabia to begin searching for alternate means of national security and deterrence capability. ${ }^{364}$

Concerns emerge, then, over Saudi Arabia's links with Pakistan. The two nations have a history of defense cooperation, and there have been conjectures of a possible nuclear link as well. In 1999, the father of Pakistan's nuclear weapons program, A.Q. Khan, briefed visiting Saudi defense officials at Pakistan's enrichment and missile assembly facilities. Later, with the dismantling of Libya's nuclear program, Khan was found to have participated in nuclear black market operations. In 2002, a son of Crown Prince Abdullah joined several Libyan and North Korean officials and others as honored guests at Pakistan's test-firing of the 950-mile range Ghauri nuclear-capable missile. ${ }^{365}$ Abdullah visited Pakistan in October of 2003, and a Pakistani official alleged to the British Guardian that Abdullah concluded a secret agreement on "nuclear cooperation" to cover nuclear technology in return for cheap oil. A strategic review reportedly considered by the Saudi government in late 2003 considered three potential options for Saudi nuclear policy: “(1) acquiring nuclear weapons for deterrent purposes; (2) maintaining an alliance or entering into a new alliance with an existing nuclear weapon power; and (3) seeking an agreement for a Middle East free of nuclear weapons." The Saudis have forcefully denied these allegations, however, calling them "baseless and totally false." ${ }^{366}$ (Bowen and Kidd 2005, Dvali 2004)

Further claims of clandestine nuclear collaborations originated from a former Saudi official, Mohammed al Khilewi. Once the first secretary for the Saudi mission to the United Nations, Khilewi declared to the London Sunday Times in 1994 that he had an archive of copies of approximately 13,000 official Saudi documents, allegedly constituting a documentation of political, economical, and human rights violations by the Saudi government. "It includes such matters as building nuclear arms, unlawful intelligence activity, illegal commissions, human rights abuses, and corruption," Khilewi asserted in an interview with Middle East Quarterly in 1998, though few of the documents have been made public. According to MEQ, Khilewi also "revealed documents showing that from 1975 until 1990, the Saudi Arabian government provided some $\$ 5$ billion to help fund Saddam Hussein's efforts to build an atomic bomb; in addition, that it tried to acquire nuclear weapons from Pakistan and the Soviet Union."367 A summary of the original published report of Khilewi's allegations states, "Saudi Arabia agreed to finance an Iraqi nuclear weapons program, designed to produce weapons-grade

\footnotetext{
${ }^{364}$ Bowen, Wyn Q. and Joanna Kidd. "The Nuclear Capabilities and Ambitions of Iran's Neighbors", Getting Ready for a Nuclear-Ready Iran. Henri Sokolski and Patrick Clawson, ed. Strategic Studies Institute, October 2005. Accessed 4 May 2007. p. 51-88. http://www.strategicstudiesinstitute.army.mil/pdffiles/pub629.pdf

${ }^{365}$ Henderson, Simon. "Toward a Saudi Nuclear Option: The Saudi-Pakistani Summit", The Washington Institute, PolicyWatch \#793, 16 October 2003. Accessed 4 May 2007. http://www.washingtoninstitute.org/templateC05.php?CID=1671

${ }^{366}$ Dvali, Akaki. "Will Saudi Arabia Acquire Nuclear Weapons?” Nuclear Threat Initiative, Center for Nonproliferation Studies, Monterey Institute of International Studies, March 2004. Accessed 4 May 2007. http://www.nti.org/e_research/e3_40a.html

367 "Mohammed Al Khilewi: 'Saudi Arabia Is Trying to Kill Me'”, Middle East Quarterly, September 1998. Accessed 4 May 2007. http://www.meforum.org/article/409
} 
material, in return for Iraqi-designed nuclear weapons and technology." ${ }^{368}$ Their collaboration halted, however, when Iraq invaded Kuwait in 1990.

The United States has also increased its level of caution regarding Saudi Arabia as a result of reports linking the Saudis to terrorist groups. ${ }^{369,370}$ Saudi citizens have been involved in multiple terrorist attacks. Four Saudis were executed for their role in a 1995 bombing at the American embassy which killed five Americans; nineteen Americans were killed and 372 others wounded in a bombing of a U.S. military housing complex in Saudi Arabia conducted by Saudi Hezbollah; and of the nineteen hijackers of commercial planes on September 11, fifteen were Saudi citizens. Islamic charities such as Muslim World League and International Islamic Relief Organization have funneled funds from Saudi Arabia to terrorist groups, with no governmental regulation or oversight. A 2002 report to the United Nations Security Council stated that al-Qaeda and other jihadist groups collected between $\$ 300$ million and $\$ 500$ million, most of which was from Saudi charities and private donors. David Kaplan of U.S. News and World Report adduced that records seized in raids after September 11 reveal weapon inventory and attack planning sponsored by these Islamic charities. ${ }^{371}$ The Saudis have recently increased controls on Islamic charities and have cracked down on terrorism.

Yet Saudi Arabia and the United States have a close relationship of economic interdependence. A large arms deal in 2000 enabled the Saudis to become the United States' largest trading partner in the Middle East, even above Israel. American oil companies have established huge investments in Saudi natural resources, and in turn, the Saudis have invested hundreds of billions of dollars in the U. S. economy. The countries maintain mutual interests in oil, which correlates to Saudi wealth, and regional security. Saudi Arabia has also shown its support for the United States in a policy change directly after 9/11: their influence on OPEC policy allowed a rush supply of oil to be provided to the United States. (Kaplan 2003, McDowell 2003)

Nevertheless, in an analysis of Arab nuclear intentions, Nuclear Threat Initiative researchers Sammy Salama and Heidi Weber state that, "No credible evidence has surfaced that points to Saudi Arabia's intention to acquire or manufacture a nuclear weapon." Despite allegations concerning collaboration with Pakistan, the researchers assert that intentions of a nuclear program partnership cannot be known. "Moreover," Salama and Weber continue, "military experts who have in-depth knowledge on Saudi armed forces and defense policies have declared that nuclear weapons are not on the Kingdom's strategic agenda." 372 It is true that, notwithstanding the aforementioned speculation and allegations concerning Saudi Arabia's nuclear program, evidence of nuclear weapons intentions and alliances has never been independently confirmed.

\footnotetext{
${ }^{368}$ Center for Nonproliferation Studies, Monterey Institute for International Studies. Abstract for Colvin, Marie. "How An Insider Lifted The Veil On Saudi Plot For An 'Islamic Bomb", Sunday Times, 24 July 1994. Accessed 4 May 2007. http://www.nti.org/db/nuclear/1994/n9411996.htm

${ }^{369}$ Kaplan, David E. “The Saudi Connection", U.S. News \& World Report, 7 December 2003.

${ }^{370}$ McDowell, Steven R. "Is Saudi Arabia a Nuclear Threat?", Naval PostGraduate School, Monterey: September 2003. Accessed 16 May 2007.

http://www.globalsecurity.org/wmd/library/news/saudi/McDowell03.pdf

${ }^{371}$ Op.cit. Kaplan

372 Salama, Sammy and Heidi Weber. "The Emerging Arab Response to Iran's Unabated Nuclear Program", Nuclear Threat Initiative, 22 December 2006. Accessed 4 May 2007.

http://www.nti.org/e_research/e3_83.html
} 
Furthermore, Saudi Arabia has policy incentives to avoid a nuclear weapons program. Nuclear weapons would have a negative political impact on the country in terms of its international relations; additionally, policy-based economic sanctions, as those imposed on Libya, could cripple a nation whose economy is based on exports. Steven McDowell of the Naval Post Graduate School concludes that the U.S. must continue to provide security assistance to Saudi Arabia. "A Saudi cost-benefit analysis dictates that breaking ties with the United States, its arms supply and logistical support far outweigh any benefits the regime may gain through an alliance with another power." ${ }^{373}$ Thus continued security provisions maintain Saudi security and decrease perceived need to develop nuclear weapons for security purposes.

Saudi Arabia is currently collaborating with the five other Gulf Cooperation Council (GCC) nations in pursuit of an Arab joint nuclear program for peaceful purposes. Though the GCC had previously shown only limited interest in developing nuclear technologies, Saudi Arabia, Kuwait, the United Arab Emirates, Qatar, Bahrain, and Oman commissioned a feasibility study in December 2006 to be conducted on employing nuclear technology for peaceful purposes in accord with international regulations and standards. The GCC Secretary General, Abderrahman Al-Attiyya of Qatar, spoke in February 2007 of the Council's ambitious goal to begin construction of a nuclear power plant by 2009. The countries plan to use nuclear power only for legal purposes, such as meeting increasing demands for electricity, water desalination, and agriculture. "AlAttiyya has said that the GCC desired to engage the IAEA in its program from the beginning since its involvement would make clear the GCC's commitment to pursuing 'a transparent process, within international standards," writes Richard Weitz of the Hudson Institute. ${ }^{374}$ Many of the details of the nuclear initiative have yet to be addressed, such as a source of fuel, location, and financing; hence, Weitz comments, "The envisaged program does not represent an immediate proliferation threat because the six member countries have only begun to examine how they might use nuclear technologies." At an early March summit in 2007, the Council issued a joint communiqué affirming their governments' desire for a WMD-free zone in the Middle East, calling for a peaceful solution regarding Iran's nuclear program, demanding Israel's accession to the NPT, and declaring their continued interest and pursuit of a nuclear research and development program for peaceful energy purposes. (Weitz 2007)

Russia has also offered its help for Saudi Arabia's and the GCC's nuclear programs. In a February 2007 visit to Saudi Arabia, Russian President Putin offered to sell weapons and help with nuclear technology. ${ }^{375}$ No further collaboration has been published in media reports.

\footnotetext{
${ }^{373}$ McDowell, Steven R. "Is Saudi Arabia a Nuclear Threat?", Naval PostGraduate School, Monterey: September 2003. Accessed 16 May 2007. http://www.globalsecurity.org/wmd/library/news/saudi/McDowell03.pdf

${ }^{374}$ Weitz, Richard. "Gulf Cooperation Council Moves Forward with Nuclear Energy Plans", WMD Insights, April 2007. Accessed 7 May 2007. http://www.wmdinsights.com/I14/I14_ME3_GCCMovesForward.htm

${ }^{375}$ Abdullaev, Nabi. "Putin Talks Arms, Nuclear Power in Gulf Visit", Defense News, 19 February 2007. Accessed 7 May 2007. http://defensenews.com/story.php?F=2560022\&C=navwar
} 


\section{ECONOMIC}

\section{Electricity}

Saudi Arabia does not import or export electricity, but produces 155.2 billion $\mathrm{kWh}$ annually, nearly all of which is generated from fossil fuels. The country consumes 144.4 billion $\mathrm{kWh}$ annually. ${ }^{376}$ Some solar and wind power is produced on a research scale, and several major research and pilot plant projects have been undertaken since the 1970 's. ${ }^{377}$

Energy consumption has been rapidly increasing in the past few decades with the expansion of power lines and the growth in population. Saudi Arabia continues to invest in power transmission, since as of 2005 about $20 \%$ of Saudis were not connected to the national power grid. ${ }^{378}$ The increase in customer base is likely to continue the trend of growing electricity consumption.

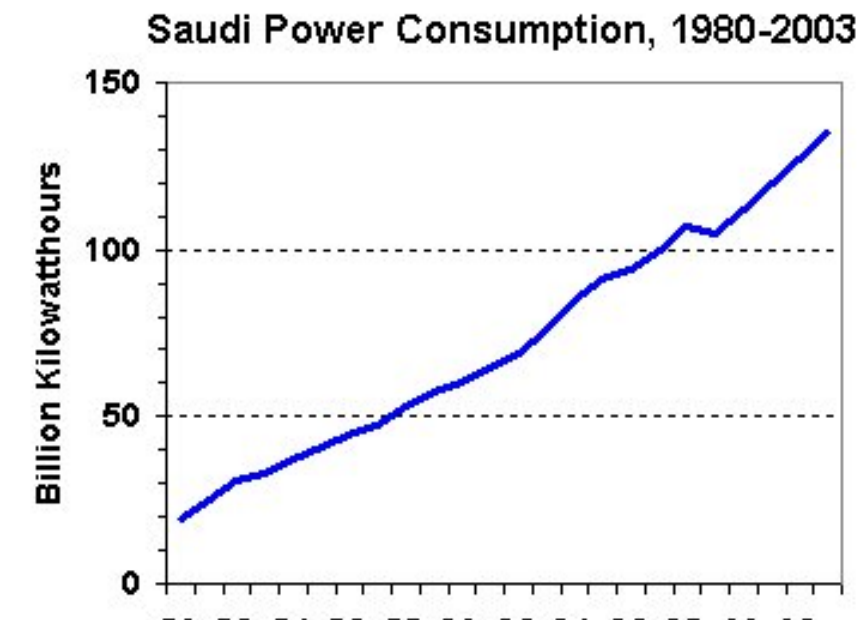

808284868890929496980002

Figure 1. Trends in Electricity Consumption in Saudi Arabia. ${ }^{379}$

Oil

According to the U.S. Department of State, "Oil was discovered in Saudi Arabia by U.S. geologists in the 1930's, although large scale production did not begin until after World War II. Oil wealth has made possible rapid economic development, which began in earnest in the 1960's and accelerated spectacularly in the 1970's, transforming the

\footnotetext{
${ }^{376}$ Central Intelligence Agency. "Saudi Arabia," The World Factbook. Last updated 17 April 2007. Accessed 2 May 2007. https://www.cia.gov/library/publications/the-world-factbook/geos/sa.html ${ }^{377}$ Huraib, Fahad S. "Saudi Arabia R\&D Effort in the Field of Solar Energy", Permanent Mission of Saudi Arabia to the United Nations. Accessed 7 May 2007. http://www.un.int/saudiarabia/solar3

${ }^{378}$ Energy Information Administration. "Saudi Arabia Country Analysis Brief", U.S. Department of Energy, August 2005. Accessed 7 May 2007. http://www.eia.doe.gov/emeu/cabs/saudi.html ${ }^{379}$ Ibid.
} 
kingdom." 380 With reserves of 262.7 billion bbl, Saudi Arabia holds one-fourth of the world's oil. The country produces 9.475 million bbl per day and consumes 1.845 million bbl per day. It does not import oil, but exports 7.92 million bbl per day. (CIA Factbook 2007)

Saudi Arabia's economy is largely oil-based with strong governmental controls. More than $95 \%$ of all Saudi oil is produced on behalf of the Saudi Government by the giant Saudi ARAMCO. The petroleum sector accounts for $45 \%$ GDP, and petroleum and petroleum products constitute $90 \%$ of exports. ${ }^{381}$ In light of these facts, the Ministry of Petroleum and Mineral Resources states, "One of the strategic objectives of the Saudi Government is to decrease the national economy's dependence on oil over the coming years." The government seeks to reinvest oil revenue in developing domestic industry and infrastructure. ${ }^{382}$

\section{Natural Gas}

Saudi Arabia produces 65.68 billion cubic meters of natural gas annually, and consumes the same. It does not import or export natural gas. Saudi Arabia's proven reserves amount to 6.654 trillion cubic meters, which are among the largest reserves in the world. ${ }^{383}$ About $60 \%$ of natural gas reserves is "associated gas" from oil fields; hence, it is projected that total reserves will be significantly increased by further oil exploration. Both production and consumption of natural gas rose at an average annual rate of $5.3 \%$ for the period from 1993 to $2003 .^{384}$

Because of its vast oil and gas resources, nuclear-power generated electricity does not seem a plausible economically sensible option for Saudi Arabia. ${ }^{385}$ Continued increased output from existing thermal generation plants or building more plants seems more economically viable. On the other hand, concerns about carbon emissions or political demand for resource diversification may create motivation for alternative energy sources.

\section{INTERNATIONAL TREATY COMMITMENTS AND IAEA COOPERATION}

IAEA Membership and International Treaty Commitments

\footnotetext{
${ }^{380}$ Bureau of Near Eastern Affairs. "Background Note: Saudi Arabia," U.S. Department of State, October 2006. Accessed 2 May 2007. http://www.state.gov/r/pa/ei/bgn/3584.htm

${ }^{381}$ Central Intelligence Agency. "Saudi Arabia," The World Factbook. Last updated 17 April 2007. Accessed 2 May 2007. https:/www.cia.gov/library/publications/the-world-factbook/geos/sa.html

${ }^{382}$ Ministry of Petroleum \& Mineral Resources. "Saudi Arabian Petroleum Policy," 2006. Accessed 7 May 2007. http://www.mopm.gov.sa/mopmr/detail.do?content=sp_policy

${ }^{383}$ Central Intelligence Agency. "Saudi Arabia," The World Factbook. Last updated 17 April 2007. Accessed 2 May 2007. https://www.cia.gov/library/publications/the-world-factbook/geos/sa.html

${ }^{384}$ Carbon Sequestration Leadership Forum. "An Energy Summary of Saudi Arabia", 29 November 2005. Accessed 7 May 2007. http://www.cslforum.org/saudiarabia.htm

385 Salama, Sammy and Heidi Weber. "The Emerging Arab Response to Iran's Unabated Nuclear Program", Nuclear Threat Initiative, 22 December 2006. Accessed 4 May 2007.

http://www.nti.org/e_research/e3_83.html
} 
Saudi Arabia joined the IAEA in 1962. It signed a Safeguards Agreement on 16 June 2005, but has not ratified it. It has not signed an Additional Protocol to the IAEA Safeguards Agreement. Saudi Arabia acceded to the Nonproliferation Treaty (NPT) in 1988, but has not signed or ratified the Limited (Partial) Test Ban Treaty or the Comprehensive Test Ban Treaty. Its participation in international agreements concerning nuclear safety and security is therefore significantly lacking. ${ }^{386,387,388,389,390,391}$

Saudi Arabia signed an IAEA's Small Quantities Protocol on 16 June 2005. The Protocol allows states to possess up to 10 tons of natural uranium or 20 tons of depleted uranium, and 2.2 pounds of plutonium without reporting. In essence, the Protocol allows Saudi Arabia to be exempt from normal IAEA inspections in return for self-regulation. The Center for Defense Information explains concerns over proliferation risks, stating "The validity of the Small Quantities Protocol is itself currently in question by the IAEA," since the allowed 'small quantities' are still sufficient for building a nuclear weapon, according to some weapon designs. ${ }^{392}$

Saudi Arabia has not established a sufficient legal framework for nuclear energy development; it seems inadequate even for general research and development. Among important agreements to which Saudi Arabia has not yet acceded are protocols and conventions regarding the privileges and immunities of the IAEA, civil liability for nuclear damage, spent fuel and waste management, and the Convention on Nuclear Safety. For a full list of Saudi Arabia's international legal commitments see Appendix I.

\section{IAEA Technical Cooperation Projects}

Saudi Arabia currently has eleven active Technical Cooperation (TC) projects in partnership with the IAEA. Topics of research include human resource development and nuclear technology support, environment and agriculture studies, and dosimetry and radiation safety. Completed Saudi projects have focused on nuclear energy planning, which was completed in 1983; prospects for nuclear desalination study, completed in 1996; and radioactive waste management, completed in $1997 .{ }^{393}$

\footnotetext{
${ }^{386}$ Office of Legal Affairs. "Saudi Arabia, Kingdom of”, Country Factsheets, IAEA. Last updated 28 March 2006. Accessed 4 May 2007. http://ola.iaea.org/factSheets/CountryDetails.asp?country=SA

${ }^{387}$ International Atomic Energy Agency. "Safeguards Current Status", 22 March 2007. Accessed 7 May 2007. http://www.iaea.org/OurWork/SV/Safeguards/sir_table.pdf

${ }^{388}$ International Atomic Energy Agency. "Strengthened Safeguards System: Status of Additional Protocols," 22 March 2007. Accessed 5 April 2007. http://www.iaea.org/OurWork/SV/Safeguards/sg_protocol.html

389 "Signatories and Parties to the Treaty on the Non-Proliferation of Nuclear Weapons", Last updated 3 December 1998. Accessed 7 May 2007. http://www.fas.org/nuke/control/npt/text/npt3.htm

${ }^{390}$ Bureau of Verification, Compliance, and Implementation, U.S. Department of State. "Treaty Banning Nuclear Weapon Tests in the Atmosphere, in Outer Space, and Under Water.” Accessed 9 April 2007. http://www.state.gov/t/ac/trt/4797.htm\#signatory

${ }^{391}$ CTBTO Preparatory Commission. "Status of Signature and Ratification." 2007. Accessed 9 April 2007. http://www.ctbto.org

${ }^{392}$ Pojedinec, Alex. "Saudi Nuclear Intentions and the IAEA Small Quantities Protocol”, Center for Defense Information, 30 June 2005. Accessed 4 May 2007. http://www.cdi.org/program/document.cfm?DocumentID=3050\&from_page=../index.cfm

${ }^{393}$ International Atomic Energy Agency, “TC Projects by Country: Saudi Arabia." Accessed 7 May 2007. http:/www-tc.iaea.org/tcweb/tcprogramme/projectsbycountry/query/default.asp
} 


\section{REGIONAL PROJECT POSSIBILITIES}

As Saudi Arabia is still in early stages of a nuclear program, it would greatly benefit from partnership with neighboring nations more advanced in nuclear programs and technological capability. Collaboration with Egypt would be particularly beneficial, as Egypt's nuclear program is much more technically advanced with significantly stronger supporting infrastructure, and would benefit from Saudi investments. Saudi Arabia already intends to cooperate with other GCC members on a nuclear program, and together they could work with Egypt on nuclear desalination and electricity generation. In order for Saudi Arabia to lead GCC countries in nuclear technology, however, it would need large foreign or government investments, substantially improved nuclear legislation and regulation, and markedly stronger technical capability. 


\section{ALGERIA}

Overview

The second largest country in Africa and eleventh in the world by area, oil-rich Algeria has recently experienced economic growth through hydrocarbon exports, despite a militant insurgency that has wrought civil instability for the past two decades. ${ }^{394}$ Algeria gained independence from France in 1962 after many years of a guerrilla war, which began with an uprising in 1954. Political violence between government forces and an Islamic insurgent group resulted in the deaths of more than 100,000 Algerians in the 1990's. Although security in the country has improved, addressing the underlying issues that brought about the political turmoil of the 1990's remains the government's major task. ${ }^{395}$

Algeria has a population of over 33 million people, of whom $99 \%$ are ArabBerber by ethnicity. The state religion is Sunni Islam, and $99 \%$ of the country practices the religion. Over $90 \%$ of the population lives along the northern fertile Mediterranean coast, although a population of about 1.5 million nomads and semi-nomadic Bedouin live in the Sahara area. Algeria's economy has grown by more than 5\% in each of the past five years, posting 5.6\% growth in 2006. Much of this economic expansion has come from increased oil prices as well as policy reforms, as the hydrocarbons sector accounts for over $95 \%$ of export earnings. However, nominal GDP per capita, \$7,700 in Algeria, is still below the world average of about $\$ 10,000$; in this respect Algeria ranks $108^{\text {th }}$ in the world. Government efforts to diversify the oil-based economy by attracting investment outside the energy sector have had little success in reducing high unemployment and improving living standards. ${ }^{396}$ The unemployment rate is reported to be about $16 \%$, though some sources estimate it is higher, and $25 \%$ of the population lives below the poverty line. Algeria's population includes 90,000 Western Saharan Sahrawi refugees, and between 400,000 and 600,000 internally displaced persons due to the conflict between government forces and Islamic insurgents.

Only 3\% of Algeria's land is arable, and less than $0.3 \%$ of the land is used for permanent crops. Environmental concerns include earthquakes, pollution, inadequate supplies of potable water, and soil erosion. Despite Algeria's extensive hydrocarbon resources, its energy use per capita is minimal at $822 \mathrm{kWh}$ per person, compared to the world average of $2,962 \mathrm{~kW}$, and miniscule relative to the $12,454 \mathrm{kWh}$ consumed in the

\footnotetext{
${ }^{394}$ In 2005 Anthony Cordesman summarized Algeria's internal conflicts as follows: "The Algerian Civil War has now gone on for well over a decade. This war has pitted a corrupt military junta, which has ruled behind the façade of an elected government, against Islamists that effectively won a popular election in the early 1990s, and were then deprived of power. When civil war broke out, violent extremist elements among these Islamists quickly came to dominate the fighting, while the military increasingly relied on equally violent repression. This civil war consumed so many resources that it led to major cuts in Algerian military modernization, although arms purchase have risen as the military have been able to sharply reduce the Islamist threat." Cordesman, Anthony. "The North Africa Military Balance: Force Developments in the Maghreb”, Center for Strategic and International Studies, 28 March 2005. Accessed 10 May 2007. http://www.csis.org/media/csis/pubs/050328_norafrimibal[1].pdf

${ }^{395}$ Bureau of Near Eastern Affairs. "Background Note: Algeria," U.S. Department of State, February 2007. Accessed 14 May 2007. http://www.state.gov/r/pa/ei/bgn/8005.htm

${ }^{396}$ Central Intelligence Agency. "Algeria," The World Factbook. Last updated 10 May 2007. Accessed 14 May 2007. https://www.cia.gov/library/publications/the-world-factbook/geos/ag.html
} 
U.S. Future economic priority areas for the Algerian government are improving the investment environment, increased privatization, and steps towards accession to the World Trade Organization. (CIA Factbook 2007, U.S. Department of State 2006)

Algeria's nuclear program began behind a veil of secrecy when China built it a research reactor in the 1980's, but the program opened to IAEA safeguards shortly thereafter following intense international pressure. Algeria has two research reactors and has conducted other research on nuclear safety, but the country has an unclear regulatory organizational structure and insufficient legal framework to support an effective, safe nuclear program.

\section{NUCLEAR INFRASTRUCTURE/INTENTIONS}

\section{Infrastructure}

\section{Knowledge management}

Algeria has a high literacy rate for Africa of $70 \%$ of the population age 15 and over who can read and write. This obfuscates a significant disparity between literacy rates for men and women (78.8\% and 61\%, respectively). Algeria's labor force consists of 9.31 million people, of whom $13.4 \%$ work in industry. ${ }^{397}$

Algeria has conducted significant research in nuclear physics since the 1970's. The following is a list of organizations whose scientists have published research related to nuclear physics in the past few decades: ${ }^{398,399}$

$\checkmark \quad$ Institut d'Etudes Nucléaires d'Alger

$\diamond \quad$ Institut de Physique, Université des Sciences et de la Technologie Houari

Boumediène

$\diamond \quad$ École Militaire Polytechnique de Bordj el Bahri

$\checkmark \quad$ Centre des Sciences et de la Technologie Nucléaires

$\checkmark \quad$ Centre de Recherche Nucléaire d'Alger

$\checkmark \quad$ Centre de Radioprotection et de Sûreté Nucléaire

$\checkmark \quad$ Centre de Recherche Nucléaire de Birine

$\checkmark \quad$ Centre de Recherche Nucléaire de Draria

Also, the Centre de Développement des Technologies Avancées (previously the Commissariat aux Énergies Nouvelles) works on renewable energy resources, but their focus is primarily solar, wind, water, and biomass energy. L'Haut Commissariat à la Recherche oversees these research institutions.

Algerian nuclear-related publications, journal articles, and conference presentations for the past few decades have covered the topics of nuclear physics, nuclear safety, plasma physics, laser research, and materials science. Scientists have studied

\footnotetext{
${ }^{397}$ Central Intelligence Agency. "Algeria," The World Factbook. Last updated 10 May 2007. Accessed 14 May 2007. https://www.cia.gov/library/publications/the-world-factbook/geos/ag.html

${ }^{398}$ Gorwitz, Mark. “Algerian Nuclear Science Bibliography”, May 2005. Accessed 11 May 2007. http://www.fas.org/nuke/guide/algeria/biblio.pdf

${ }^{399}$ International Atomic Energy Agency, "TC Africa: Member States, Information Records on Algeria." Accessed 9 May 2007. http://www-tc.iaea.org/tcweb/regionalsites/africa/country/default.asp?cid=ALG
} 
radioactive decay, gamma radiation, neutron cross-sections, cold fusion, and fission in nuclear physics; they have also researched dosimetry, contamination monitoring, $\mathrm{x}$-ray and gamma-ray detection, environmental gamma radiation monitoring, plutonium isotopes in marine sediments (Nouredine \& Baggoura 1997), and "Determination of Small Quantities of Plutonium with Solid State Nuclear Track Detectors" (Dahmane 1985 ) in terms of nuclear safety. On research reactors, several articles have been published on both pressurized water reactors (PWR) and light water research reactors (LWRR). Extraction, reprocessing, and other chemical studies have been conducted on uranium extraction from phosphoric acid, tritium enrichment and separation from water, the dissolution of yellowcake, uranium ore waste treatment, and "Calculation of plutonium content and isotope balance in plate and fuel pin elements" (Guedioura 1996). (Gorwitz 2005). ${ }^{400}$

\section{Uranium Resources}

Uranium exploration began in Algeria in 1969. Initial explorations found several radioactive anomalies, and prospecting teams conducted follow-up explorations on these sites throughout the 1970's and 1980's. An aerial radiometric survey over the entire country was performed in 1971. However, there have been very few exploration or prospecting activities in recent years. Today an IAEA database lists Algeria as having five dormant uranium deposits at Abankor, Daira, Tahaggart, Timgaouine, and Tinef. All of these deposits are categorized as "vein type" except Tahaggart, which is a sandstonebasal channel. Algeria officially reports total "Reasonably Assured Resources" of 26,000 tons uranium with initial grade from 0.1 to $0.5 \%$ uranium. ${ }^{401,402}$ The Stockholm International Peace Research Institute (SIPRI) estimates Algeria's total uranium resources at about 56,000 tons uranium. ${ }^{403}$

Phosphates are among Algeria's main exports, and the U.S. Geological Survey reports average Algerian production of over one million tons of phosphate rock annually from 1997 to 2001 . $^{404}$ Uranium can be extracted from phosphates using a technology first developed by the Atomic Energy Commission in the $1950 \mathrm{~s}$, in which $\mathrm{U}_{3} \mathrm{O}_{8}$ is extracted, converted into $\mathrm{UF}_{6}$, enriched, and eventually manufactured into pellets used for fuel rods in nuclear power reactors. ${ }^{405}$ This process is more expensive than mining natural uranium, but importing and refining phosphates can be more attractive politically than obtaining uranium from an international source. The Algerian Materials Development Center (CDM) researched removal and recovery of uranium from

\footnotetext{
${ }^{400}$ Gorwitz, Mark. “Algerian Nuclear Science Bibliography”, May 2005. Accessed 11 May 2007. http://www.fas.org/nuke/guide/algeria/biblio.pdf

${ }^{401}$ INFCIS, "World Distribution of Uranium Deposits: Algeria." International Atomic Energy Association, 2003. Accessed 8 May 2007. http://www-nfcis.iaea.org/Default.asp

${ }^{402}$ Joint Report by the OECD Nuclear Energy Agency and the International Atomic Energy Agency. Uranium 2005:Resources, Production, and Demand, Paris: OECD Publishing, 2005.

${ }^{403}$ Stockholm International Peace Studies Institute. "Countries of Strategic Nuclear Concern - Algeria, Nuclear Facilities Profile.” July 2004. Accessed 10 May 2007. http://www.sipri.org/contents/expcon/cnsc3alg.html

${ }^{404}$ Mobbs, Philip M. "The Mineral Industry of Algeria”, U.S. Geological Survey Minerals Yearbook, 2001. Accessed 8 May 2007. http://minerals.er.usgs.gov/minerals/pubs/country/2001/agmyb01.pdf

${ }^{405}$ Talbot, Stephen. "Westinghouse backs King Hassan's Desert War." Multinational Monitor, Vol. 1 No. 10, November 1980. Accessed 23 April 2007. http://multinationalmonitor.org/hyper/issues/1980/11/talbot.html
} 
phosphates as part of a technical cooperation project with the IAEA, completed in 1994. 406

\section{Nuclear Reactors and Fuel Facilities}

Algeria has two research reactors and a nuclear waste storage facility, but no known fuel fabrication facilities or reprocessing facilities.

Es-Salam research reactor (DZ-0002) was secretly constructed by China in the 1980's; under U.S. pressure, it became subject to international inspections the same year as its criticality date, in 1992. Owned by the Ministry of Scientific Research and operated by Centre de Development des Systèmes Energétiques, Es-Salam is a $15 \mathrm{MW}$ heavy water reactor with a maximum thermal neutron flux of $2.1 \times 10^{14} \mathrm{n} / \mathrm{cm}^{2}-\mathrm{s}, 14$ cadmium control rods, and 45 vertical channels used for neutron activation analysis. The reactor uses low enriched uranium (LEU) fuel originating from China. ${ }^{407,408}$ SIPRI comments on its potential capabilities:

"The reactor has been at the center of heated debates since Western intelligence agencies first discovered its existence. Some analysts believe that it may be capable of producing up to 3 kilograms of plutonium per year from spent fuel and possibly more."

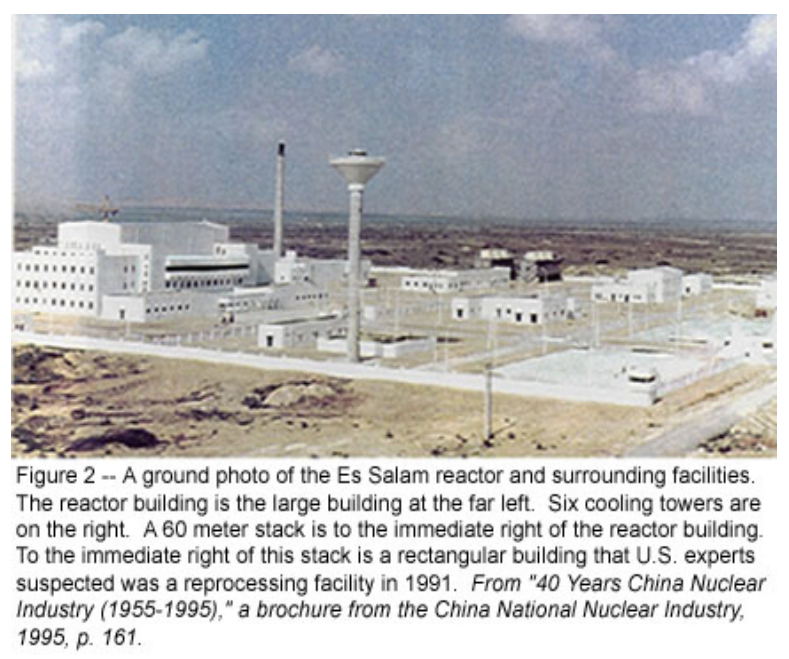

Figure 1. The Es Salam reactor at Ain Oussera, 250 kilometers south of Algiers. ${ }^{410}$

\footnotetext{
406 “Uranium Extraction from Phosphoric Acid”, International Atomic Energy Agency. ALG/3/004. http://www-tc.iaea.org/tcweb/projectinfo/projectinfo_body.asp

407 Research Reactor Database. "Nuclear Research Reactors in the World: Algeria", International Atomic Energy Agency, 1999. Last updated 20 September 1994. Accessed 8 May 2007. http://www.iaea.org/worldatom/rrdb/

${ }^{408}$ Wisconsin Project on Nuclear Arms Control. "Algeria: Nuclear Reactor Update", The Risk Report, Vol. 1 No. 5, June 1995. Accessed 9 May 2007. http://www.wisconsinproject.org/countries/algeria/reacupdt.html

${ }^{409}$ Stockholm International Peace Studies Institute. "Countries of Strategic Nuclear Concern - Algeria, Nuclear Facilities Profile.” July 2004. Accessed 10 May 2007.

http://www.sipri.org/contents/expcon/cnsc3alg.html

${ }^{410}$ Institute for Science and International Security. "Annotated images of Algeria's nuclear site at Ain Oussera”, 2001. Accessed 9 May 2007. http://www.isis-online.org/publications/algeria/figure2.jpg
} 
The facilities include a hot cell laboratory and an isotope production facility; there are suspicions of a reprocessing plant as well, discussed in further detail below.

The Nur research reactor (DZ-0001) is a pool-type reactor that creates a steady thermal power of $1 \mathrm{MW}$. It is owned by the Ministry of Scientific Research and operated by the Division of Nuclear Energy Research (URGN). Argentina's INVAP built the Nur reactor, which reached criticality in 1989 and has a maximum thermal neutron flux of $8.9 \times 10^{12} \mathrm{n} / \mathrm{cm}^{2}-\mathrm{s}$; Argentina also provided the $19.75 \%$ enriched uranium fuel for the reactor. Nur is used for laboratory scale production of radioisotopes, neutron radiography, applied research in neutron physics, and training of reactor-operating personnel. Within the reactor are neutron beam extraction channels, a hot cell laboratory, and a supplementary control console for training purposes. ${ }^{411,412}$

No nuclear fuel cycle facilities are listed in the IAEA database. ${ }^{413}$ However, an Argentinean summary of Argentina's international nuclear cooperation and exports describes collaboration with Algeria on a possible fuel fabrication facility for which construction began in the mid-1980's. ${ }^{414}$ Domestic security issues delayed construction, but the summary reports, "By mid-1991 the plant was $90 \%$ completed and might have been entirely completed within 6 months"; the project then halted for several years again due to civil unrest. When security conditions improved in 1998, construction resumed, and it was reported to be completed in 2000 . The facility appears to be a small pilot plant used for manufacturing nuclear fuel elements and the conversion of uranium concentrates into $\mathrm{UO}_{2}$. According to the report, "The Fuel Element Pilot Plant and Auxiliary Facilities consist of: a plant for MTR-type plates; a powder metallurgy plant; a fuel element plant; an assembly plant; a machinery and maintenance room and a project and engineering office." On the suspected fuel fabrication facility, "According to open-sources, it may also be capable of producing fuel for future plants such as HWRs [heavy water reactors] and PHWRs [pressurized heavy water reactors]." 415

Also, Algeria reports no spent fuel reprocessing capability, though speculations of Algerian reprocessing research have been voiced since the early 1990's. Leonard Spector of the Carnegie Endowment states, "Several unconfirmed reports indicate that Algeria has begun to construct a nuclear fuel reprocessing plant next to the [Es Salam] reactor (located at Ain Oussera), a facility that presumably could have been used to separate weapons-usable plutonium from the reactor's spent fuel." A 1998 article published in El Pais describes a report by Spain's intelligence organization Cesid. Cesid reportedly stated that the objectives of nuclear agreements signed with China and Argentina

${ }^{411}$ Research Reactor Database. "Nuclear Research Reactors in the World: Algeria", International Atomic Energy Agency, 1999. Accessed 8 May 2007. http://www.iaea.org/worldatom/rrdb/

${ }^{412}$ INVAP. "Reactor NUR (Algeria) - Introduction", 2003. http://www.invap.net/nuclear/nur/intro-e.html ${ }^{413}$ INFCIS, "Nuclear Fuel Cycle Information System, List of Nuclear Fuel Cycle Facilities: Algeria." International Atomic Energy Association, 2003. Last updated 24 November 1993. Accessed 8 May 2007. http://www-nfcis.iaea.org/Default.asp

${ }^{414}$ Omstein, Roberto Mario. "Argentina as an Exporter of Nuclear Technology: Past, Present, and Future", Consejo Argentino para las Relaciones Internacionales (Argentinean Council for International Affairs CARI), 2001. Accessed 9 May 2007. http://www.cari1.org.ar/pdf/nucleareng.pdf

${ }^{415}$ Stockholm International Peace Studies Institute. "Countries of Strategic Nuclear Concern - Algeria, Nuclear Facilities Profile.” July 2004. Accessed 10 May 2007. http://www.sipri.org/contents/expcon/cnsc3alg.html 
included the production of military grade plutonium, and Cesid is said to have determined that Algeria has "a capability in the nuclear area much superior to their needs". 416 Algerian authorities rejected the Cesid report as "fantasies". 417

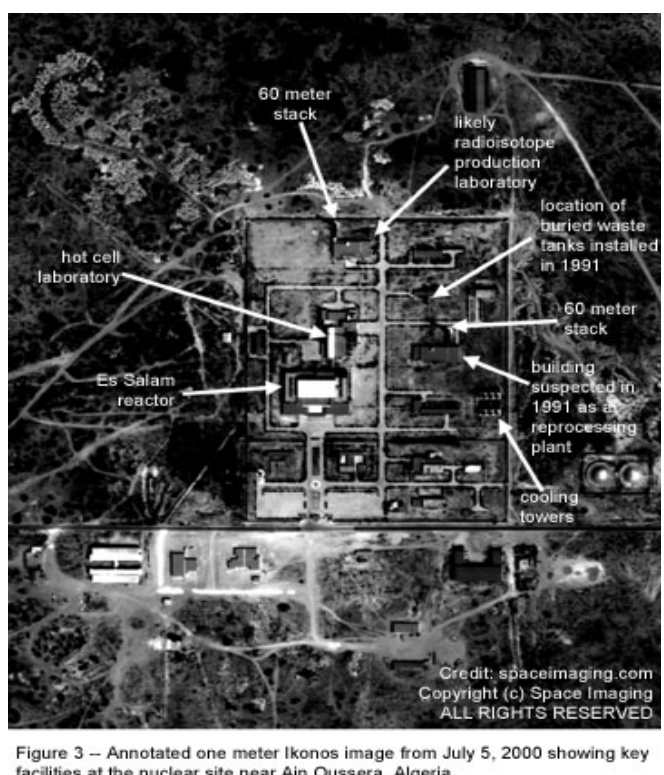

Figure 2. The Es Salam reactor at Ain Oussera, 250 kilometers south of Algiers. ${ }^{418}$

An auxiliary pool for spent-fuel storage has also been built at this site near the Es
Salam reactor.

$\underline{\text { Regulation }}$

Minimal information was found on precise roles of the many nuclear research agencies and centers in Algeria. As mentioned previously, the Centre de Development des Systèmes Energétiques manages the Es Salam reactor, as well as the waste management facility. URGN manages the Nur reactor. One may suppose that Algeria's Centre de Radioprotection et de Sûreté Nucléaire assumes a role in radiation safety, though further details are not known. The liaison officer for Technical Cooperation (TC) projects with the IAEA in Algeria is Mr. Merzak Remki of the Commissariat à l'énergie

\footnotetext{
${ }^{416}$ Gonzáles, M. and J. M. Larraya. "El Cesid warns that Algeria can have the capacity to produce military plutonium in two years", El Pais, Madrid: 23 August 1998. Accessed 10 May 2007. http://www.isisonline.org/publications/algeria/elpais.html

${ }^{417}$ Center for Nonproliferation Studies, Monterey Institute for International Studies. "The Cesid Warns That Within Two Years Algeria Will Have The Capacity To Produce Military Plutonium", Abstract. Nuclear Threat Initiative, 2003. Accessed 10 May 2007. http://www.nti.org/db/nuclear/1998/n9818217.htm ${ }^{418}$ Institute for Science and International Security. "Annotated images of Algeria's nuclear site at Ain Oussera", 2001. Accessed 9 May 2007. http://www.isis-online.org/publications/algeria/figure3.jpg ${ }^{419}$ Stockholm International Peace Studies Institute. "Countries of Strategic Nuclear Concern - Algeria, Nuclear Facilities Profile.” July 2004. Accessed 10 May 2007. http://www.sipri.org/contents/expcon/cnsc3alg.html
} 
atomique (COMENA), and most TC projects are organized under the auspices of COMENA. ${ }^{420,421}$

\section{Intentions}

Algeria's domestic nuclear program did not begin until the 1980's. ${ }^{422}$ Algeria's nuclear program was originally conducted secretly, when China began building the Es Salam reactor around 1985. In early 1991, routine satellite surveillance led U.S. intelligence to the chance discovery that Algeria was constructing a nuclear reactor and other facilities in a remote desert region of the country. This validated suspicions about Algeria's nuclear ambitions, which some analysts speculate arose in response to a perceived Libyan threat of an emerging nuclear program under Qadhafi. ${ }^{423}$ Under intense international pressure, Algeria acceded to IAEA safeguards and opened the Es Salam reactor to inspections in 1992. Actual capability of the reactor, $15 \mathrm{MW}$ with production of a few grams of plutonium annually, was found to be much less than some estimates; along with the opening of the program to inspections, knowledge of the limited production capability helped to resolve concerns. ${ }^{424}$ Further, Algeria later signed the Nonproliferation Treaty (NPT) in 1995 and the Comprehensive Test Ban Treaty (CTBT) in $1996 .{ }^{425}$

Algeria's Technical Cooperation program with the IAEA from about 2001 to 2005 focused on potential applications of nuclear science and technology to development needs "of social and economic significance" such as nuclear medicine, water resources management, and improved agricultural production. ${ }^{426}$ Following similar announcements by Egypt and Morocco, Khalil announced in November 2006 Algeria's plan to pursue a nuclear energy program in order to exploit the country's substantial uranium resources. With significant uranium deposits that had been recently discovered and the rising price of uranium that allowed other deposits to be economically exploitable, Algeria was said to have greater capability to pursue a domestic nuclear program. This announcement had precedent, as Khalil had previously stated Algeria's goal of "integrated development of

\footnotetext{
${ }^{420}$ International Atomic Energy Agency. "National Liaison Officers in Africa on 11 May 2007," Accessed 11 May 2007. http://www-tc.iaea.org/tcweb/regionalsites/africa/lists/liaisonofficers/

${ }^{421}$ International Atomic Energy Agency, "TC Africa: Member States, Information Records on Algeria." Accessed 9 May 2007. http://www-tc.iaea.org/tcweb/regionalsites/africa/country/default.asp?cid=ALG

${ }^{422}$ Pike, John. "Weapons of Mass Destruction: Algeria Special Weapons", Global Security. Last modified 28 April 2005. Accessed 10 May 2007. http:/www.globalsecurity.org/wmd/world/algeria/index.html 423 Ibid.

${ }^{424}$ Salama, Sammy and Heidi Weber. "The Emerging Arab Response to Iran's Unabated Nuclear Program", Center for Nonproliferation Studies, Monterey Institute for International Studies. Nuclear Threat Initiative, 22 December 2006. Accessed 10 May 2007. http:/www.nti.org/e research/e3 83.html

${ }^{425}$ Barletta, Michael, and Erik Jorgensen. "Weapons of Mass Destruction Capabilities and Programs", Center for Nonproliferation Studies, Monterey Institute for International Studies. Last updated April 2006. Accessed 10 May 2007. http://cns.miis.edu/research/wmdme/algeria.htm

${ }^{426}$ International Atomic Energy Agency, "TC Africa: Member States, Country Overview for Algeria", 2005. Accessed 10 May 2007. http://www-tc.iaea.org/tcweb/regionalsites/africa/documents/ALG2005.pdf
} 
the entire nuclear sector and its applications: seawater desalination, industry, agriculture, medicine, the environment, and, in particular, electricity." 427

More recently, Algeria has sought collaboration with other nations on its nuclear program, including South Korea, Russia, France, the United States, and perhaps Iran. In May 2006, eleven Algerian delegates visited South Korea to discuss bilateral nuclear cooperation, including the exchange of oil, gas, and mining resources for an expanded nuclear capacity. ${ }^{428}$ Algeria and Russia signed an agreement in March 2006 on the sale of up to $\$ 7.5$ billion of Russian weapons to Algeria, financed by Russian exploration and production of Algerian oil and natural gas. It was reported that Russia offered help in constructing nuclear facilities and in training Algerian scientists and technicians during the Russian Energy Minister's follow-up visit to Algiers in January 2007. ${ }^{429}$ Press reports have announced possible nuclear assistance from France and the United States. One noted that France's new Prime Minister Nicolas Sarkozy established a policy during his 2007 election campaign that France should help other countries build nuclear power plants, beginning with Algeria. ${ }^{430}$ Another reported an announcement by the Minister of Energy and Mineral Resources, Shakib Khalil, in May 2007 to the Algerian press that an agreement had been reached with the U.S. on the use of nuclear energy for civilian purposes. Khalil was said to express interest in establishing sister laboratories and benefiting from American expertise, and a joint project is expected to be finalized in June. $^{431}$

Algeria appears to have ties to Iran and Iranian nuclear programs. In November 2006, Khalil traveled to Iran, where President Mahmoud Ahmadinejad offered Iranian assistance for Algeria's nuclear program, stating Iran's willingness "to share its expertise in different fields with Algeria, including peaceful nuclear technology." The offer was warmly received by Khalil, who asserted that Algeria "is very interested in Iranian expertise in various fields, especially in oil, gas, and nuclear energy." 432 Algeria has been consistently supportive of Iran in Iran's confrontation with the international community over its pursuit of a complete nuclear fuel cycle. Algeria has come to Iran's defense noting that enrichment and plutonium separation are rights protected by the NPT. Furthermore, Algeria abstained from crucial IAEA votes that asserted Tehran's

\footnotetext{
${ }^{427}$ Khalid Hilal. "Algeria announces plans for expanded nuclear energy program; Iran offers to help", WMD Insights, February 2007. Accessed 10 May 2007. http://www.wmdinsights.com/I12/I12_AF1_IranAlgeriaOffer.htm

${ }^{428}$ Salama, Sammy and Heidi Weber. "The Emerging Arab Response to Iran's Unabated Nuclear Program", Center for Nonproliferation Studies, Monterey Institute for International Studies. Nuclear Threat Initiative, 22 December 2006. Accessed 10 May 2007. http://www.nti.org/e_research/e3_83.html

429 "Algeria trades gas for Russian nuclear energy", World Tribune, Cairo: 24 January 2007. Accessed 10 May 2007. http://www.worldtribune.com/worldtribune/07/front2454125.1611111113.html

${ }^{430}$ Sciolino, Elaine. "Sarkozy outlines foreign policy", International Herald Tribune, 28 February 2007. Accessed 11 May 2007. http://www.iht.com/articles/2007/02/28/news/france.php

431 "Algeria Gets US Support for Use of Nuclear Energy for Civilian Purposes, Says Minister", The North Africa Journal, 9 May 2007. Accessed 11 May 2007. http://www.north-africa.com/opensource/story1may0907.htm

${ }^{432}$ Khalid Hilal. "Algeria announces plans for expanded nuclear energy program; Iran offers to help", WMD Insights, February 2007. Accessed 10 May 2007. http://www.wmdinsights.com/I12/I12_AF1_IranAlgeriaOffer.htm
} 
noncompliance with IAEA inspections and referred the Iranian case to the UN for further action. $^{433}$

Algeria has not yet stated its intentions regarding uranium enrichment or plutonium separation from spent reactor fuel. Concerns over clandestine assistance for an enrichment program consequently arise, as well as unease regarding Algeria's potential for misuse considering its secretive nuclear history.

In terms of other international collaboration, Algeria was honored by hosting an IAEA conference in January 2007, the first to be hosted in Africa. Over 30 states, mostly from Africa, attended the conference on the peaceful applications of nuclear energy, such as electricity generation and nuclear desalination. Participants affirmed "Africa's strategic choice for the exclusively peaceful use" of nuclear technology. ${ }^{434,435}$

Due to Algeria's limited water resources, water desalination is among the most likely applications of nuclear technology. Demand for fresh water in Algeria greatly exceeds supply, with most residents of the capital city of Algiers having access to potable water for only a few hours each day. ${ }^{436}$ Current natural renewable water resources amount to about 460 cubic meters per capita annually; ${ }^{437}$ by comparison, per capita renewable water resources in the United States are about 7,178 cubic meters. ${ }^{438}$ At present, Algeria is seeking to supply its domestic water needs through thermal desalination. The Ministry of Energy and Minerals reports, "In order to satisfy the national demand for water, a national program aims to construct more sea water desalination units on the Algerian coast with a total capacity of 1.8 million cubic meters per day," a project which is hoped to be completed in $2009 .{ }^{439}$ Through the investment and partnership of private industries from the U.S., Spain, and Canada, Algeria has obtained the capital for construction of these facilities. The largest plant, a reverse osmosis facility to be built by General Electric in Hamma, will supply 200,000 cubic meters of water daily, enough for $25 \%$ of the population of Algiers. ${ }^{440}$

Algeria has initiated research in nuclear desalination as an alternative to current plans of thermal desalination. Algeria is currently conducting two IAEA technical cooperation programs on nuclear desalination: a feasibility study, and research on

\footnotetext{
${ }^{433}$ Khalid Hilal. "Algeria announces plans for expanded nuclear energy program; Iran offers to help", WMD Insights, February 2007. Accessed 10 May 2007. http://www.wmdinsights.com/I12/I12_AF1_IranAlgeriaOffer.htm

434 "Algeria to shelter nuclear energy conference", Algeria Events, 27 December 2006. Accessed 10 May 2007. http://www.algeria-events.com/article640.html

435 "High Level Regional Conference on Nuclear Energy", TC Africa, 24 January 2007. Accessed 10 May 2007. http://www-tc.iaea.org/tcweb/regionalsites/africa/news/newsstory/default.asp?newsid=200

${ }^{436}$ GE Imagination at Work. "Desalination: Algiers, Algeria". Accessed 11 May 2007. http://ge.ecomagination.com/site/index.html\#algiers

437 "Water Resources and Freshwater Ecosystems - Algeria", EarthTrends Country Profile, 2003. Accessed 11 May 2007. http://earthtrends.wri.org/pdf_library/country_profiles/wat_cou_012.pdf 438 "Water Resources and Freshwater Ecosystems - United States", EarthTrends Country Profile, 2003. Accessed 14 May 2007. http://earthtrends.wri.org/pdf_library/country_profiles/wat_cou_840.pdf 439 “Bilan du Secteur de l'Energie et des Mines, 2000-2005", Ministère de l'Energie et des Mines, March 2006. Accessed 11 May 2007. http://www.mem-algeria.org/statistics/Bilan_MEM_2000-2005-fr.pdf

${ }_{440}$ Press Release, "GE Announces Plans for Largest Desalination Plant in Africa", 25 June 2005. Accessed 11 May 2007. http://www.gewater.com/pdf/pr/20050623PR.pdf
} 
strengthening of infrastructure needed for further development of a future nuclear desalination program (See Appendix Q). ${ }^{441}$

\section{ECONOMIC}

\section{Electricity}

Algeria produces 29.39 billion kWh of electricity annually (2004 est.), almost all of which is produced by thermal plants. Algeria consumes 27.4 billion $\mathrm{kWh}$; exports and imports account for less than $1 \%$ of production and consumption. ${ }^{442}$

The Ministry of Energy and Mining states that economic expansion is expected to increase the demand for electricity. "Thus, production is expected to increase from $26,250 \mathrm{GWH}$ in 2001 to $46,000 \mathrm{GWH}$ in 2010 ," with an average increase in consumption of $6 \%$ annually. Increases in uranium prices, combined with Algeria's extensive uranium resources, have made nuclear energy a more economically viable option for electricity generation.

Algeria certainly has more than sufficient oil and natural gas resources to supply its electricity needs, but as gas prices continue to increase, an alternate source of domestic electricity becomes increasingly attractive. Moreover, the Ministry of Energy and Mining has a stated goal of reducing pollution by decreasing carbon emissions. ${ }^{443}$ To this end, Algeria has pursued other renewable energy programs for electricity generation, particularly solar and wind power. The Algerian company Sonelgaz has established a strong solar energy program that supplies energy to remote villages in southern Algeria, where fuel transportation or extension of a transmission grid would be far too costly. Today, about 876 households in 20 villages have consumed 284,543 kWh since the commissioning of the project. ${ }^{444}$ Wind power is also being studied and has been implemented in several other remote villages. Another project seeks to build a $150 \mathrm{MW}$ solar-gas hybrid power generation plant. ${ }^{445}$

Algeria's electric grid is in the process of integrating with other Maghreb countries to link eventually the power grids of the Maghreb countries to Spain and the European Union. Algeria is already linked to Tunisia's electrical grid, and efforts to connect to Libya's grid to the network are in process. This would ultimately link power grids from Morocco to Egypt. First, however, Maghreb countries' domestic power grids

\footnotetext{
${ }^{441}$ International Atomic Energy Agency, "TC Africa: Member States, Information Records on Algeria." Accessed 9 May 2007. http://www-tc.iaea.org/tcweb/regionalsites/africa/country/default.asp?cid=ALG ${ }^{442}$ Central Intelligence Agency. "Algeria," The World Factbook. Last updated 10 May 2007. Accessed 14 May 2007. https:/www.cia.gov/library/publications/the-world-factbook/geos/ag.html

443 "Bilan du Secteur de l'Energie et des Mines, 2000-2005", Ministère de l'Energie et des Mines, March 2006. Accessed 11 May 2007. http://www.mem-algeria.org/statistics/Bilan_MEM_2000-2005-fr.pdf

444 "Presentation on the 20 solar villages in the South of Algeria", Ministry of Energy and Mining. Accessed 11 May 2007. http://www.mem-algeria.org/enr/solar_energy/the_prest_20_solar_vil.htm 445 "Solar Villages", Ministry of Energy and Mining. Accessed 11 May 2007. http://www.memalgeria.org/enr/index.htm
} 
must be upgraded to meet domestic demand and ensure greater reliability, for which projects are already under way. ${ }^{446}$

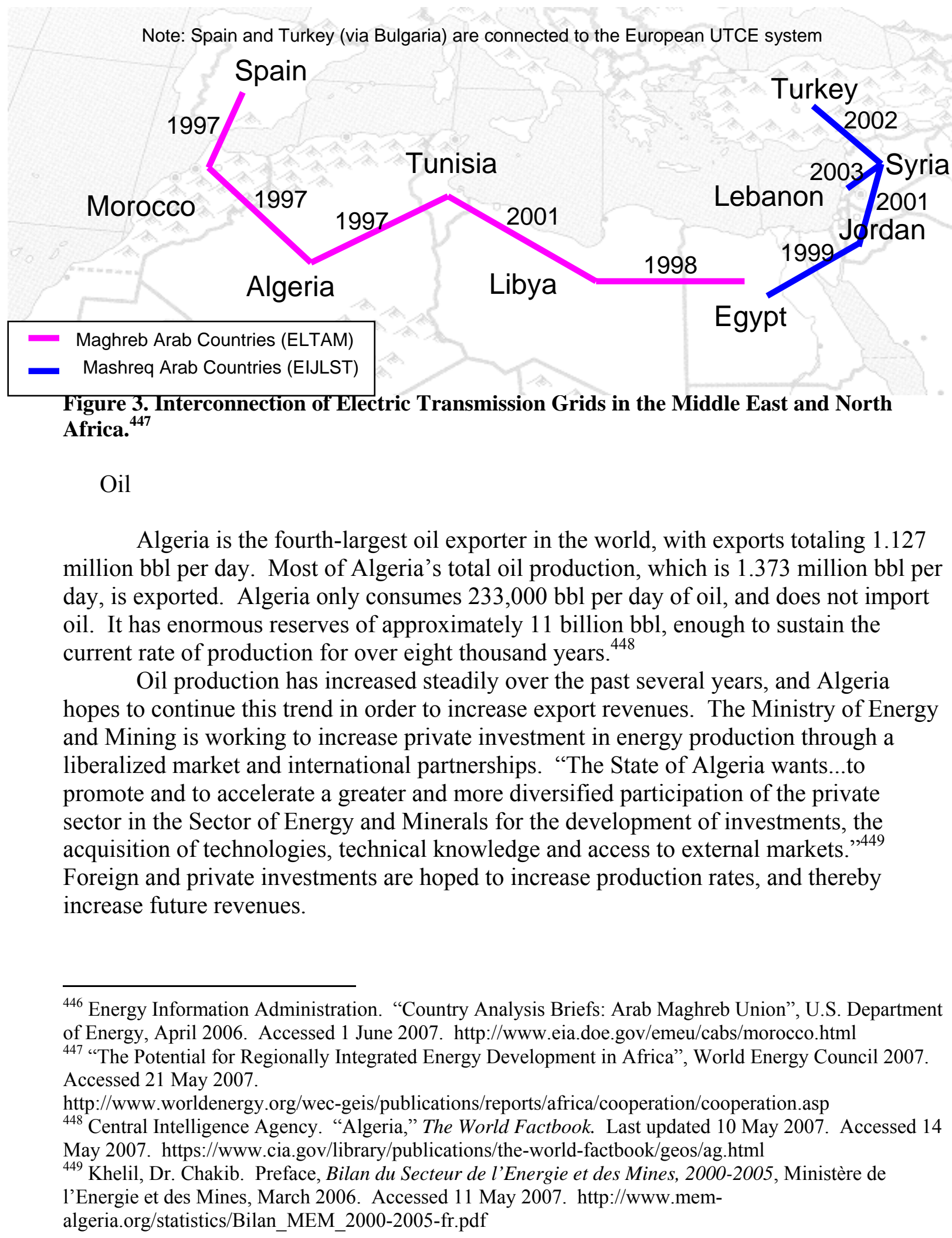




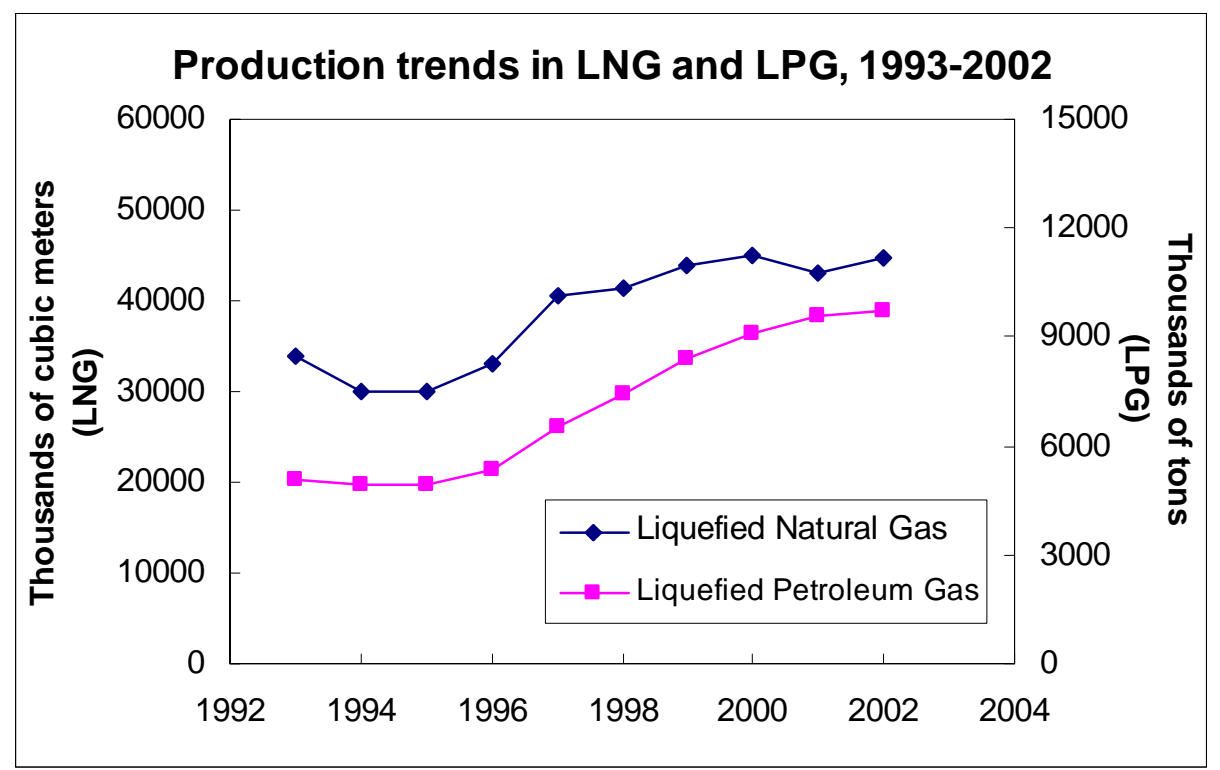

Figure 4. Algerian production of Liquefied Natural Gas (LNG) and Liquefied Petroleum Gas (LPG). ${ }^{450}$

Natural Gas

Algeria has the eighth-largest natural gas reserves in the world, with 4.545 trillion cubic meters. It produces 80.15 billion cubic meters annually; in 2004 Algeria's production was second-largest among OPEC countries, behind Iran. The country consumes less than a fourth of the quantity produced, only 19.28 billion cubic meters. The Ministry of Energy and Mining expects annual domestic consumption to increase to 21 billion cubic meters annually by 2010 , and hopes to increase transportation networks to reach remote customers. ${ }^{451}$ Algeria does not import natural gas, but exports 60.87 billion cubic meters annually. ${ }^{452,453}$

\section{INTERNATIONAL TREATY COMMITMENTS AND IAEA COOPERATION}

IAEA Membership and International Treaty Commitments

Algeria became a member of the IAEA in 1963, and has since signed and ratified several important nuclear-related international agreements. Algeria acceded to the Treaty

\footnotetext{
${ }^{450}$ Data from "LPG and GNL Production, 1993-2002", Ministry of Energy and Mining. Accessed 11 May 2007. http://www.mem-algeria.org/statistics/lpg_lng_93_02.htm

451 "Prospects for natural gas development 2000/2010", Ministry of Energy and Mining. Accessed 11 May 2007. http://www.mem-algeria.org/electricity/index.htm

${ }^{452}$ Central Intelligence Agency. "Algeria," The World Factbook. Last updated 10 May 2007. Accessed 14 May 2007. https:/www.cia.gov/library/publications/the-world-factbook/geos/ag.html

${ }^{453}$ Energy Information Administration. "Algeria: Natural Gas", U.S. Department of Energy. Accessed 7 June 2007. http://www.eia.doe.gov/emeu/cabs/Algeria/NaturalGas.html
} 
on the Non-Proliferation of Nuclear Weapons (NPT) on 12 January $1995,{ }^{454}$ with a Safeguards Agreement pursuant to the NPT entering into force on 7 January 1997. ${ }^{455}$ Algeria signed the Comprehensive Test Ban Treaty in October 1996 and ratified it in July $2003,{ }^{456}$ but only signed and did not ratify the Limited (Partial) Test Ban Treaty. ${ }^{457}$ The country also has not signed or ratified an Additional Protocol to its Safeguards Agreement. ${ }^{458}$

Algeria ratified the Chemical Weapons Convention in August 1995. The country conducted a basic research effort on biological weapons, but acceded to Biological Toxins Weapons Convention in July 2001. ${ }^{459}$

Algeria has not established sufficient legal infrastructure for nuclear energy development; it seems inadequate even for general nuclear research and development. Among important agreements to which Algeria has not yet acceded are agreements and conventions regarding the privileges and immunities of the IAEA, civil liability for nuclear damage, spent fuel and waste management, and the Convention on Nuclear Safety. For a full list of Algeria's commitments to multilateral conventions and safeguards agreements with the IAEA, see Appendix J.

\section{IAEA Technical Cooperation Projects}

Algeria has had considerable involvement in the IAEA Technical Cooperation program conducting a total of 60 current Technical Cooperation (TC) projects, of which 14 are national projects, 40 are regional, and 6 are interregional. Some of these projects focus on building infrastructure for further nuclear techniques, such as human resource development, strengthening of the Es Salam reactor, nuclear security, assessing radioactive residue at nuclear test sites, and strengthening the national radiation protection infrastructure. Others focus on preparation for specific nuclear technologies, such as preparation for nuclear power or feasibility studies for nuclear desalination. A third category of projects applies already accessible nuclear techniques to fields of

\footnotetext{
${ }^{454}$ Barletta, Michael, and Erik Jorgensen. "Weapons of Mass Destruction Capabilities and Programs", Center for Nonproliferation Studies, Monterey Institute for International Studies. Last updated April 2006. Accessed 10 May 2007. http://cns.miis.edu/research/wmdme/algeria.htm

${ }^{455}$ International Atomic Energy Agency. “Agreement of 30 March 1996 Between the People's Democratic Republic of Algeria and the International Atomic Energy Agency for the Application of Safeguards in connection with the Treaty on the Non-Proliferation of Nuclear Weapons", January 1997. INFCIRC/531. Accessed 14 May 2007. http://inis-a4.iaea.org/fulltext/p/28/028/28028756.pdf

${ }^{456}$ CTBTO Preparatory Commission. "Status of Signature and Ratification." 2007. Accessed 14 May 2007. http://www.ctbto.org

${ }^{457}$ Bureau of Verification, Compliance, and Implementation, U.S. Department of State. "Treaty Banning Nuclear Weapon Tests in the Atmosphere, in Outer Space, and Under Water.” Accessed 14 May 2007. http://www.state.gov/t/ac/trt/4797.htm\#signatory

${ }^{458}$ International Atomic Energy Agency. "Strengthened Safeguards System: Status of Additional

Protocols," 22 March 2007. Accessed 14 May 2007.

http://www.iaea.org/OurWork/SV/Safeguards/sg_protocol.html

${ }^{459}$ Barletta, Michael, and Erik Jorgensen. "Weapons of Mass Destruction Capabilities and Programs", Center for Nonproliferation Studies, Monterey Institute for International Studies. Last updated April 2006. Accessed 10 May 2007. http://cns.miis.edu/research/wmdme/algeria.htm
} 
nuclear medicine, agriculture, water resource management, and combating desertification. ${ }^{460}$

From 1997 to 2002, TC programs worked to strengthen the capabilities and safety of the two research reactors. The TC program from 2002 to 2005 focused on applications of radioisotopes, including prospecting of nuclear raw materials, radioactive waste management, radiation protection regulatory control, environmental monitoring, and radiation emergency planning and preparedness; other projects focused on nuclear medicine, hydrology, and agriculture. ${ }^{461}$

\section{REGIONAL PROJECT POSSIBILITIES}

Algeria has been active in African issues, and is working towards improved international relations with Europe and other Western nations. It continues to have tense relations with Morocco regarding the sovereignty of Western Sahara: Algeria supports Morocco's rival army, the Polisario Front, in the territory. This has led to concerns regarding border security between the countries. Algeria has friendly relations with the other nations of the Maghreb, Libya and Tunisia.

Algeria has been strongly supportive of the international war on terrorism, according to the U.S. Department of State, perhaps as a result of its experience with Islamic militancy at home. The U.S. and Algeria have a "growing relationship" in "key areas of mutual concern, including law enforcement and counter-terrorism operation," and have collaborated in military training and exercises. ${ }^{462}$ American companies have also played a major role in developing Algeria's oil and gas sector.

Collaboration on developing internal regulation, international legal agreements, and increased nuclear safety and security would greatly benefit Algeria's nuclear program. Such partnership could come from the U.S., as America is already significantly involved in local industry. Egypt could also offer assistance, perhaps in exchange for a supply of Algeria's uranium resources. Because Algeria has already developed two nuclear research reactors domestically, with improved safety and nonproliferation regulation, it could become a nuclear center for its neighbors as well.

\footnotetext{
${ }^{460}$ International Atomic Energy Agency, "TC Africa: Member States, Information Records on Algeria." Accessed 9 May 2007. http://www-tc.iaea.org/tcweb/regionalsites/africa/country/default.asp?cid=ALG ${ }^{461}$ International Atomic Energy Agency, "Country Overview for Algeria, 2005." Accessed 11 May 2007. http://www-tc.iaea.org/tcweb/regionalsites/africa/documents/ALG2005.pdf

${ }^{462}$ Bureau of Near Eastern Affairs. "Background Note: Algeria," U.S. Department of State, February 2007. Accessed 14 May 2007. http://www.state.gov/r/pa/ei/bgn/8005.htm
} 


\section{TUNISIA}

Overview

Tunisia is a small country in northern Africa, bordering Algeria and Libya, which first gained independence from France in 1956. Tunisia has very good relations with Western countries, including the United States, and plays a major role in African politics and the Middle East peace process. Critics note that domestic political life is not yet fully democratic: citizens' freedoms of association and speech are restricted, and the government does not allow a free press; progress could also be made in terms of the separation of powers. On the other hand, Tunisia's current President, Zine El Abidine Ben Ali, has instituted important measures for progress towards full democracy, and the country has been a leader in the Arab world in promoting the rights of women since its independence. Tunisia gave women full legal status in 1956, has outlawed polygamy, and requires education for girls. ${ }^{463}$ (U.S. State Department 2006)

About the size of Georgia, and slightly smaller than Syria, Tunisia ranks $91^{\text {st }}$ in area among the nations of the world. Tunisia has a large percentage of fertile land, compared to similar nations, with over $17 \%$ arable land and $13 \%$ permanent crops. Still, Tunisia has limited fresh water, and environmental concerns include desertification and pollution. With a population of just over 10 million, Tunisia ranks $77^{\text {th }}$ in the world. The vast majority of the population is Arab by ethnicity, and 98\% are Muslim, with small Jewish minorities on the southern island of Djerba and elsewhere, as well as a small Christian minority. Progressive social policies have raised living conditions, such that now only $7.4 \%$ of the population lives below the poverty line (compared to $12 \%$ in the United States), though unemployment rates are still high. Current nominal GDP per capita is $\$ 8,600$, below the world average of about $\$ 10,000$. Despite large fluctuations due to high oil prices and variations in rainfall, overall GDP growth rate has been fairly strong. Compared with other Middle Eastern nations, Tunisia spends a small percentage of its GDP on military expenditures: only $1.5 \%$. Tunisia continues to ease governmental controls for increased privatization and liberalization to increase economic expansion. Per capita electricity usage, $1,066 \mathrm{kWh}$, is about a third of the world average of 2,962 $\mathrm{kW}$, and is miniscule relative to the $12,454 \mathrm{kWh}$ per capita consumed in the United States. Further privatization and foreign investment, improvements in government efficiency, and reduction of the trade deficit are important priorities for Tunisia's future economic development. ${ }^{464}$ (CIA Factbook 2007, U.S. Department of State 2006)

Tunisia has initiated major steps in the process of expanding its nuclear program, such as developing a regulatory agency and participating with the IAEA on relevant technical cooperation projects. With limited water resources and substantial recent increases in natural gas consumption and oil imports, Tunisia is looking for alternative energy sources and desalination techniques. The country has yet to accede to significant international protocols, but after implementing these, and with collaboration with closely-

\footnotetext{
${ }^{463}$ Bureau of Near Eastern Affairs. "Background Note: Tunisia," U.S. Department of State, October 2006. Accessed 14 May 2007. http:/www.state.gov/r/pa/ei/bgn/5439.htm

${ }^{464}$ Central Intelligence Agency. "Tunisia," The World Factbook. Last updated 10 May 2007. Accessed 14 May 2007. https://www.cia.gov/library/publications/the-world-factbook/geos/ts.html
} 
linked Maghreb and North African countries, Tunisia could further develop its nuclear program to pursue nuclear energy for peaceful purposes.

\section{NUCLEAR INFRASTRUCTURE/INTENTIONS}

\section{Infrastructure}

\section{Knowledge management}

Literacy for the population of Tunisia is high relative to other African countries, with $74.3 \%$ of the population over age 15 who can read and write, though there is a significant disparity between literacy rates for men and women $(83.4 \%$ and $65.3 \%$, respectively). Despite economic improvements from liberalization, a high unemployment rate, which is officially reported to be about $14 \%$, plagues the economy. Tourism, manufacturing and textiles, and agriculture are the main sectors, supported by a labor force of 3.5 million people. (CIA Factbook 2007, U.S. Department of State 2006)

Tunisia's Ministry of Higher Education, Scientific Research and Technology oversees technical research conducted through the following seven research institutions: the Institute of Sea Science and Technology, the Center for the Study of Economic and Social Research, Arid Regions Institute, the Biotechnology Center, the National Institute of Physical Chemistry Research and Analysis, the National Center of Scientific and Technical Documents, and the National Center for Nuclear Science and Technology. Together, these organizations consist of thousands of researchers with a large budget, who have published 431 journal articles in 2003, of which at least 55 were related to radio physiological health. ${ }^{465}$ Increases in personnel, funding, and published results are all priorities for the Ministry of Higher Education. ${ }^{466}$

The National Center for Nuclear Science and Technology (CNSTN) is the main nuclear research and training institution in Tunisia. ${ }^{467}$ Located at the technology center at Sidi Thabet, CNSTN houses several laboratories for nuclear research and regulation. These include an isotopic hydrology laboratory, a facility for radiopharmaceuticals, a pilot plant for radiation treatment for food processing and other agricultural applications, a nuclear instrumentation lab, a radioanalytic facility, and laboratories for microbiology, radioprotection, and radiochemistry. Created in 1993, the Center's four-fold mission is research development, dissemination of nuclear-related information for science and technology applications, technical support for universities and public and private enterprises, and the establishment of a working nuclear infrastructure for peaceful applications of nuclear techniques. CNSTN now conducts many projects in a wide variety of nuclear applications, though it has not yet established a research center specifically for nuclear energy research. Researchers at the center have published works on seawater desalination with nuclear techniques. ${ }^{468}$

\footnotetext{
${ }^{465}$ Repertoire des References des Publications Scientifiques des Laboratoires de Recherche Tunisiens, Ministère de la Recherche Scientifique, de la Technologie et du Développement des Compétences, 2003. Accessed 16 May 2007. http://www.mrstdc.gov.tn/version_anglaise/laboratoire_unite/ref_revues.doc ${ }^{466}$ Ministry of Higher Education, Scientific Research and Technology, http://www.mrstdc.gov.tn/

${ }^{467}$ Centre National des Sciences et Technologies Nucléaires, http://www.cnstn.rnrt.tn/index.php

${ }^{468}$ See, for example, Bouzguenda, N., S. Nisan, and M. Albouy. "Financing of an integrated nuclear desalination system in developing countries," International Journal of Nuclear Desalination, Vol. 205, 2007. pp. 317-331. http://www.desline.com/articoli/8149.pdf
} 


\section{Uranium Resources}

Tunisia does not have any identified uranium deposits. ${ }^{469,470}$ The country, however, is a leading exporter of phosphates. Uranium can be extracted from phosphates using a technology first developed by the Atomic Energy Commission in the 1950s, in which $\mathrm{U}_{3} \mathrm{O}_{8}$ is extracted, converted into $\mathrm{UF}_{6}$, enriched, and eventually manufactured into pellets used for fuel rods in nuclear power reactors. ${ }^{471}$ This process is more expensive than mining natural uranium, but importing and refining phosphates can be more attractive politically than obtaining uranium from an international source. In Tunisia, phosphates are mined by the Compagnie des Phosphates de Gafsa, which states that natural phosphate and by-products are exported to 50 different countries. ${ }^{472}$ In 1999 , Tunisian production of phosphates peaked at 8 million tons, ranking fifth in the world in terms of phosphate production.

\section{Nuclear Reactors and Fuel Facilities}

As of 2000, Tunisia had one nuclear fuel cycle facility "under study". ${ }^{473}$ It was intended for use in recovering uranium from phosphates, with a design capacity of 120 tons uranium per year and to be located in Gabes. Owned by the Tunisian government, it was planned to be operated by La Société des Industries Chimiques.

As of 1999, Tunisia had planned the construction of a light-water TRIGA research reactor, called TRR, with a steady thermal power of $2 \mathrm{MW}{ }^{474}$

Tunisia has small quantities of radioactive waste from medical and research facilities and spent sealed sources, but the country does not have a central waste management facility. Radioactive waste from medical and research facilities are stored at their institutions, controlled by the National Center for Radioprotection (CNRP). In 2000 , it was projected that a central waste storage site would be erected with the Environmental Ministry (MEAT), which would collect and store all spent sealed sources by $2006 .{ }^{475}$

\section{$\underline{\text { Regulation }}$}

CNSTN is the main regulatory agency for nuclear material used in non-medical areas of research. The Radioprotection Division of the Center works on projects

\footnotetext{
${ }^{469}$ Joint Report by the OECD Nuclear Energy Agency and the International Atomic Energy Agency. Uranium 2005:Resources, Production, and Demand, Paris: OECD Publishing, 2005. p. 215-9.

${ }^{470}$ Integrated Nuclear Fuel Cycle Information Systems, World Distribution of Uranium Deposits Database. International Atomic Energy Agency. 2003. Accessed 25 April 2007. http://www-nfcis.iaea.org/

${ }^{471}$ Talbot, Stephen. "Westinghouse backs King Hassan's Desert War." Multinational Monitor, Vol. 1 No. 10, November 1980. Accessed 23 April 2007.

http://multinationalmonitor.org/hyper/issues/1980/11/talbot.html

${ }^{472}$ Compagnie des Phosphates de Gafsa. "Tunisian Phosphate Industry", http://www.gct.com.tn/

${ }^{473}$ NFCIS, "List of Nuclear Fuel Cycle Facilities: Tunisia." International Atomic Energy Association, 2003. Last updated 31 January 2000. Accessed 8 May 2007. http://www-nfcis.iaea.org/Default.asp

${ }^{474}$ Research Reactor Database. "Nuclear Research Reactors in the World: Tunisia", International Atomic Energy Agency, 1999. Last updated 6 April 1999. Accessed 14 May 2007.

http://www.iaea.org/worldatom/rrdb/

${ }^{475}$ International Atomic Energy Agency. "Country Waste Profile Report for Tunisia, Reporting Year: 2000”, 2003. Accessed 16 May 2007. http://www-pub.iaea.org/MTCD/publications/PDF/rwmp5/CWP_Tunisia_2000.pdf
} 
concerning nuclear safety, radiation protection and dosimetry for both persons and the environment, and physical protection against theft or burglary for radioactive sources. The division participates in the activities of numerous establishments, including industry, hospitals, laboratories, and nuclear facilities. ${ }^{476}$

CNRP is located at the Children's Hospital in Bab Saâdoun. This organization has worked on projects such as "the drafting of a law on the land transport of dangerous goods, including radioactive substances," research on "patient doses from diagnostic radiology," and other health, dosimetry, and medical physics related research and regulation. $^{477}$

Intentions

Tunisia intends to develop nuclear research and technology capability for nuclear desalination and electricity production purposes, as well as other medical and agricultural applications. Nuclear desalination is an attractive prospect for the country in particular because of its limited fresh water resources, as well as the country's economic dependence on agriculture and tourism. Water supply is particularly inadequate in southern Tunisia, where some researchers assert that maximum exploitation of natural water has already occurred. ${ }^{478}$ A research report by H. Ben-Kraïem of the CNSTN states that natural surface and groundwater resources will satisfy the water demand for only a few more years, particularly since lake water and other water resources are too high in salinity to be potable. Ben-Kraïem reports, "It is expected that by the year 2010 all these water resources will have been exploited."479 Mohamed Megahed of Cairo's Nuclear Power Plants Authority asserts that Tunisia already has already a deficit of $50,000 \mathrm{~m}^{3}$ per day of potable water, and this deficit is expected to reach about $100,000 \mathrm{~m}^{3}$ per day in $2010{ }^{480}$ Figure 1 shows growth in Tunisia's population since 1990, and still greater growth in water demand, about $4.1 \%$ annually, over the same period.

\footnotetext{
${ }^{476}$ Centre National des Sciences et Technologies Nucléaires, Unité de Radioprotection. http://www.cnstn.rnrt.tn/radioprotection_prestations.php

477 See, for example, Omrane, L. Ben, N. Chahed and S. Mtimet, "Patient Doses from Diagnostic Radiology." Accessed 16 May 2007. http://irpa11.irpa.net/pdfs/4b16.pdf; International Atomic Energy Agency General Conference, "Measures to Strengthen International Co-operation in Nuclear, Radiation and WAste Safety", 12 August 1998. GC(42)/INF/6. Accessed 16 May 2007. http://f40.iaea.org/GC/gc42/documents/gc42inf6.pdf

${ }^{478}$ Megahed, Mohamed M. "Nuclear Desalination: history and prospects", International Journal of Nuclear Desalination, Vol. 135, 2001. pp. 169-185. Accessed 17 May 2007. http://www.desline.com/articoli/4047.pdf

${ }^{479}$ Ben-Kraïem, H. "The Seawater Desalination Needs of Tunisia after the Year 2010", http://inisdb.iaea.org/fulltext/p/32/001/32001530.pdf

${ }^{480}$ Megahed, Mohamed M. "Nuclear Desalination: history and prospects", International Journal of Nuclear Desalination, Vol. 135, 2001. pp. 169-185. Accessed 17 May 2007. http://www.desline.com/articoli/4047.pdf
} 


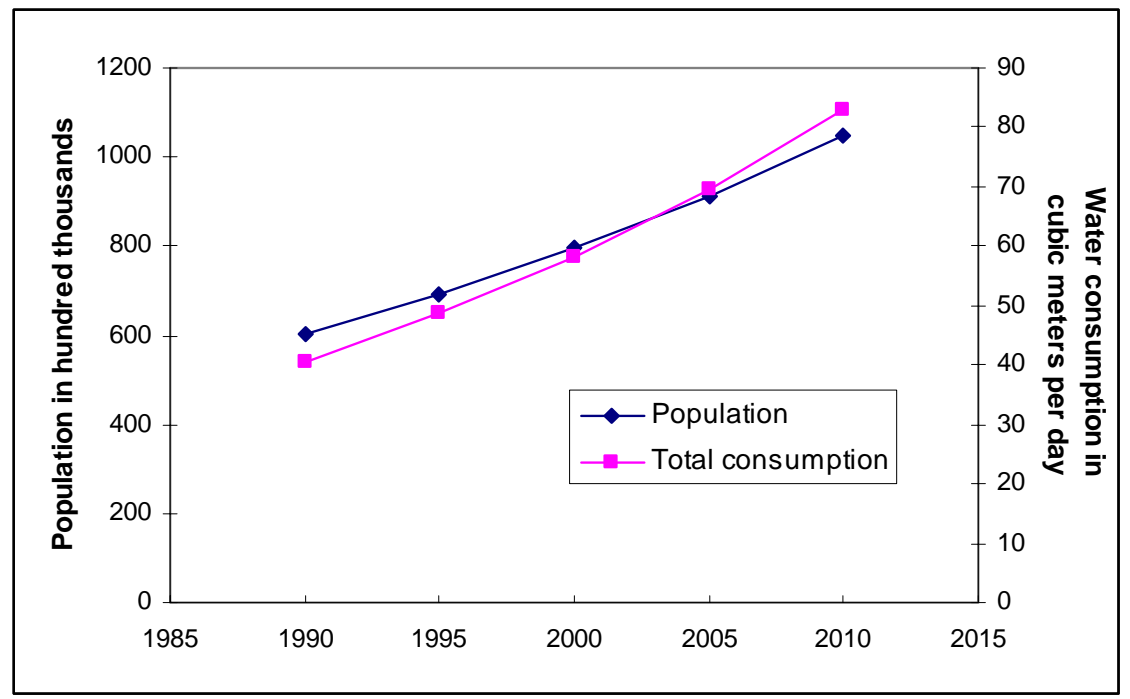

Figure 1. Population and Water Demand Growth in Southern Tunisia (projected data after 2000). ${ }^{481}$

Limited water resources are already being supplemented by conventional desalination plants. Tunisia currently manages four electrical brackish water desalination plants, which use the reverse osmosis process to produce about $60,000 \mathrm{~m}^{3}$ per day of water. Tunisia has also treated significant quantities of waste water in an effort to conserve natural resources. ${ }^{482,483}$

CNSTN has also studied electricity generation through nuclear energy, arguing that, "A diversification of energy resources seems to be an appropriate option for guaranteeing the smooth functioning of the sector." 484 According to the U.S. Department of State, Tunisia is currently a net importer of hydrocarbon products. ${ }^{485}$ Tunisia has only one oil refinery, which is located at Bizerte. This small refinery has a production capacity of 34,000 bbl per day; yet because of its limited refining capability, Tunisia must export crude oil and import refined products. Furthermore, regarding future possibilities for Tunisia's oil industry, the Energy Information Administration concludes, "Tunisia should to be able to supply at least part of its own petroleum needs for the next decade, but significant production thereafter will be contingent upon new discoveries." $" 486$ Because of Tunisia's current and increasing dependence upon imported oil, Tunisia is seeking to diversify its energy resources for greater economic sustainability.

\footnotetext{
${ }^{481}$ Ben-Kraïem, H. "The Seawater Desalination Needs of Tunisia after the Year 2010", http://inisdb.iaea.org/fulltext/p/32/001/32001530.pdf

${ }^{482}$ Ibid.

483 "SONEDE in figures", SONEDE National Water Distribution Utility, 2005. Accessed 18 May 2007. http://www.sonede.com.tn/an/E_SC.html

${ }^{484}$ M.B.R. "Un rayonnement bénéfique dans plusieurs domains", CNSTN (Translated from the French). Accessed 17 May 2007. http://www.cnstn.rnrt.tn/usage_energie_nucleaire.php

${ }^{485}$ Bureau of Near Eastern Affairs. "Background Note: Tunisia," U.S. Department of State, October 2006. Accessed 14 May 2007. http://www.state.gov/r/pa/ei/bgn/5439.htm

${ }^{486}$ Energy Information Administration. "Country Analysis Briefs: Arab Maghreb Union”, U.S. Department of Energy, April 2006. Accessed 17 May 2007.

http://commercecan.ic.gc.ca/scdt/bizmap/interface2.nsf/vDownload/CABS_0005/\$file/maghreb.pdf
} 
CNSTN has worked on this problem, citing increases in consumption of electrical energy, rising gas prices, economic development, and a burgeoning standard of living as well as dependence on oil imports as strong incentives for an alternative source of energy. Regarding the economics of nuclear electricity generation, CNSTN's Director General Adel Trabelsi said a "recent leading study by the Center demonstrated that the production of nuclear electricity would be competitive with classical methods for a price of 30 dollars per barrel of petrol.... At this stage, the production of electricity by nuclear energy would appear largely profitable.",487

Other feasibility studies have concurred. Technical and economic feasibility studies were conducted for an integrated nuclear desalination facility, producing electricity and desalted water, in Tunisia by a collaboration of France's Atomic Energy Commission (CEA) and Tunisia's CNSTN; this project is called TUNDESAL. The desalination facility would be located in Skhira in southern Tunisia, in the area of Sfax and Gabes. The plant would produce $600 \mathrm{MW}$ for the Tunisian electric grid by the year 2020 , as well as between $48,000 \mathrm{~m}^{3}$ and $150,000 \mathrm{~m}^{3}$ per day of desalinated water. In light of increasing demand for water, limited natural supply, increasing population and variations in rainfall, the feasibility studies were found to "clearly demonstrate the overall economic competitiveness and technological feasibility of nuclear desalination projects." ${ }^{, 48}$ Furthermore, building a larger nuclear reactor could be feasible and still more economical, should Tunisia's electric grid be connected with that of Europe. A study has been completed looking at this possibility. ${ }^{489}$ The CEA/CNSTN partnership has now turned to financing options, due to the high capital investment required to build such a plant. In this regard, one study conducted by the University of Grenoble and the CEA concluded that, "The nuclear option for water desalination appears as financially more profitable than any of the fossil energy based options." ${ }^{490}$ Recently, Tunisia organized a project team with the participation of three relevant government ministries (Nuclear Research and Technology, Electricity, and Water) to carry out another feasibility study of a nuclear cogeneration plant for electricity and water in the country. In December 2006, CNSTN and CEA signed a cooperation agreement on peaceful applications of nuclear energy. France upheld its close political and economic ties with Tunisia, as Tunisia's leading foreign investor, by establishing an accord for partnership on the peaceful use of nuclear technology for environmental protection, nuclear medicine, nuclear desalination, and nuclear electricity generation. ${ }^{491,492}$

\footnotetext{
${ }^{487}$ M.B.R. "Un rayonnement bénéfique dans plusieurs domains", CNSTN (Translated from the French). Accessed 17 May 2007. http://www.cnstn.rnrt.tn/usage_energie_nucleaire.php

${ }^{488}$ Bouzguenda, N., S. Nisan, and M. Albouy. "Financing of an integrated nuclear desalination system in developing countries," International Journal of Nuclear Desalination, Vol. 205, 2007. pp. 317-331. http://www.desline.com/articoli/8149.pdf

${ }^{489}$ Baccouche, S. et al. "Economical and Technical Feasibility Study of Nuclear Desalination for the Skhira Site in Tunisia: Project 'Tundesal'”. http://inisdb.iaea.org/fulltext/p/37/095/37095439.pdf

${ }^{490}$ Methnani, M. and R. Faibish. "Status of design concepts of nuclear desalination plants", International Atomic Energy Agency, November 2002. IAEA-TECDOC-1326. Accessed 17 May 2007. http://wwwpub.iaea.org/MTCD/publications/PDF/te_1326_web.pdf

491 "Tunisie - France : Signature d'un accord de coopération entre le CNSTN et le CEA", CNSTN, 14 December 2006. Accessed 17 May 2007. http://www.cnstn.rnrt.tn/actualite_detail.php?id_actualite=20 492 "Tunisia, France strike deal on peaceful use of nuclear energy", People's Daily Online, $\overline{1} 5$ December 2006. Accessed 17 May 2007. http://english.people.com.cn/200612/15/eng20061215_332862.html
} 
In terms of nonproliferation, Tunisia has consistently maintained a strong nuclear nonproliferation foreign policy by supporting WMD-free zones in Africa and the Middle East, by urging international cooperation for disarmament, and by organizing a North African workshop on nonproliferation in 2004. In addition to signing the Nonproliferation Treaty in 1989, Tunisia signed the African Nuclear-Weapon-Free Zone Treaty as well. The country has also worked on and supports efforts for a nuclearweapon-free zone in the Middle East. ${ }^{493}$

Tunisia has expressed concern over Israel's nuclear capability, noting in a statement to the UN General Assembly that, "The Israeli position constituted an obstacle to disarmament efforts, in general, and to the achievement of durable peace in the region." their capabilities against non-nuclear states: "While awaiting the total elimination of nuclear weapons, non-nuclear-weapon States [have] the duty to ask for effective guarantees against the use or threat of use of those weapons against States that had voluntarily renounced them."495 Yet Tunisia affirms its position of support for nonproliferation efforts by calling on the international community to promote a multilateral approach in order to rid the world of nuclear weapons and to strengthen international security. Tunisia's policy reflects the perspective that investment in a nuclear weapon program is "often carried out at the expense of the basic needs of the civil populations and their development." 496

\section{ECONOMIC}

\section{Electricity}

Tunisia produces about 11.81 billion $\mathrm{kWh}$ of electricity, the vast majority of which is generated by fossil fuel plants. Tunisia consumes about 10.97 billion $\mathrm{kWh}$ of electricity, and this amount is increasing with a burgeoning population and increased access to the electrical grid. The Tunisian Society of Electricity and Gas (STEG) reports that $99.2 \%$ of the country now has access to the electrical grid, up from $86 \%$ in 1994 , and from $21 \%$ when STEG was founded in $1962 .{ }^{497,498}$ In addition, the United Nations Environment Program calculates that national demand for electricity increased by $6.5 \%$

493 “2002 NPT Preparatory Committee: Tunisia”, 12 April 2002. NPT/CONF.2005/PC.1/3/Add.2. Accessed 17 May 2007. http://www.basicint.org/nuclear/NPT/2002prepcom/Rpts-SArab\&Tunis.htm

${ }^{494}$ Hachani, Ali. “" 'Tension between Nuclear Legality and Nuclear Reality' Cause of Crisis in Nuclear Non-Proliferation Regime, Disarmament Committee Told”, Statements, Fifty-ninth General Assembly, First Committee, $7^{\text {th }}$ Meeting, 12 October 2004. GA/DIS/3277. Accessed 18 May 2007. http://www.un.org/News/Press/docs/2004/gadis3277.doc.htm

495 Ibid.

496 Ibid.

${ }^{497}$ Energy Information Administration. “Country Analysis Briefs: Arab Maghreb Union,” U. S. Department of Energy, April 2006. Accessed 18 May 2007. http://commercecan.ic.gc.ca/scdt/bizmap/interface2.nsf/vDownload/CABS_0005/\$file/maghreb.pdf ${ }^{498}$ STEG "History: The Gas Activity," http://www.steg.com.tn/en/institutionnel/Historique_Gaz.html 
annually from 1990 to $2000 .^{499}$ Tunisian exports of electricity amount to 15 million $\mathrm{kWh}$, and imports are 5 million kWh. (CIA Factbook 2007)

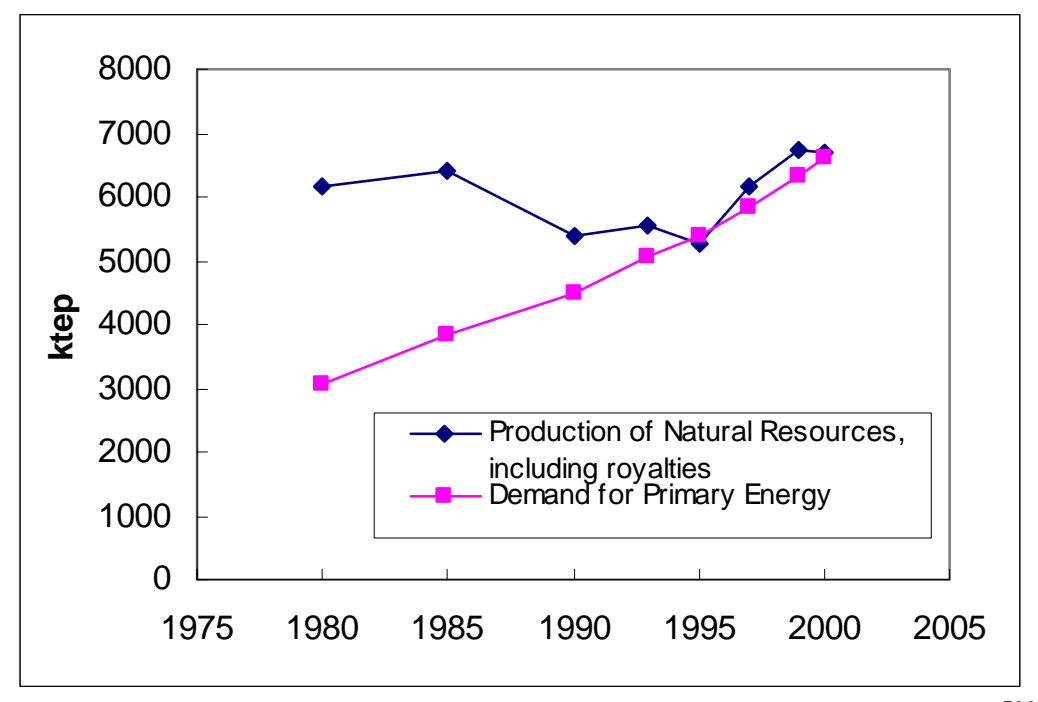

Figure 2. Domestic Production and Demand for Energy Resources. ${ }^{500}$

A decline in domestic production of hydrocarbons, the consequent decline in hydrocarbon exports, and economic growth have led to a significant increase in domestic energy needs. To satisfy increasing demand, the Tunisian government intends to intensify efforts for research and exploration of further hydrocarbon resources, and to increase focus on developing alternative energy resources. In this regard, the government has dedicated significant financial resources to expanding electricity production capacity in existing thermal plants. In addition to STEG, Tunisia has promoted the creation of two Independent Power Plants in order to reach its goal of an installed capacity of 3,540 MW. Other plants are under negotiation with British Petroleum (BP). ${ }^{501}$ Tunisia is also actively researching alternative energy resources, especially wind power. In 2003, the U.S. Department of Energy estimated that over $99 \%$ of Tunisia's electrical energy was generated from fossil fuel thermal power plants, $0.6 \%$ from hydroelectric power, and approximately $0.3 \%$ from renewable resources such as wind and biomass. ${ }^{502} \mathrm{~A}$ windmill farm in Hawariya has a total capacity of $20 \mathrm{MW}$; generation capability is hoped to increase eventually to $100 \mathrm{MW}{ }^{503}$ The homepage of the STEG website offers tips on

\footnotetext{
${ }^{499}$ Missaoui, Rafik and Samir Amous. "Financing the Development of the Renewable Energy in the Mediterranean Region, Baseline Study for Tunisia", Division of Technology, Industry, and Economics, United Nations Environment Programme, May 2003.

http://www.uneptie.org/energy/act/fin/medrep/MEDREP_\%20Tunisia\%20baseline.pdf

${ }^{500}$ Ibid.

${ }^{501}$ Energy Information Administration. “Country Analysis Briefs: Arab Maghreb Union”, U.S. Department of Energy, April 2006. Accessed 17 May 2007.

http://commercecan.ic.gc.ca/scdt/bizmap/interface2.nsf/vDownload/CABS_0005/\$file/maghreb.pdf

502 "Republic of Tunisia," International Atomic Energy Agency, Energy and Environment Data Reference Bank, 2005. Accessed 18 May 2007. http://www.iaea.org/inisnkm/nkm/aws/eedrb/data/TN-elpo.html

${ }^{503}$ Energy Information Administration. "Country Analysis Briefs: Arab Maghreb Union", U.S. Department of Energy, April 2006. Accessed 17 May 2007.

http://commercecan.ic.gc.ca/scdt/bizmap/interface2.nsf/vDownload/CABS_0005/\$file/maghreb.pdf
} 
energy-saving mechanisms, such as a solar-powered heater and energy efficient light bulbs. ${ }^{504}$

Tunisia's electric grid is in the process of integrating with other Maghreb countries to link eventually the power grids of the Maghreb countries to Spain and the European Union. Algeria is already linked to Tunisia's electrical grid, and efforts to connect to Libya's grid are in process, which would ultimately link power grids from Morocco to Egypt. First, however, Tunisia's domestic power grid must be upgraded to meet domestic demand and ensure greater reliability, for which projects are already under way. 505

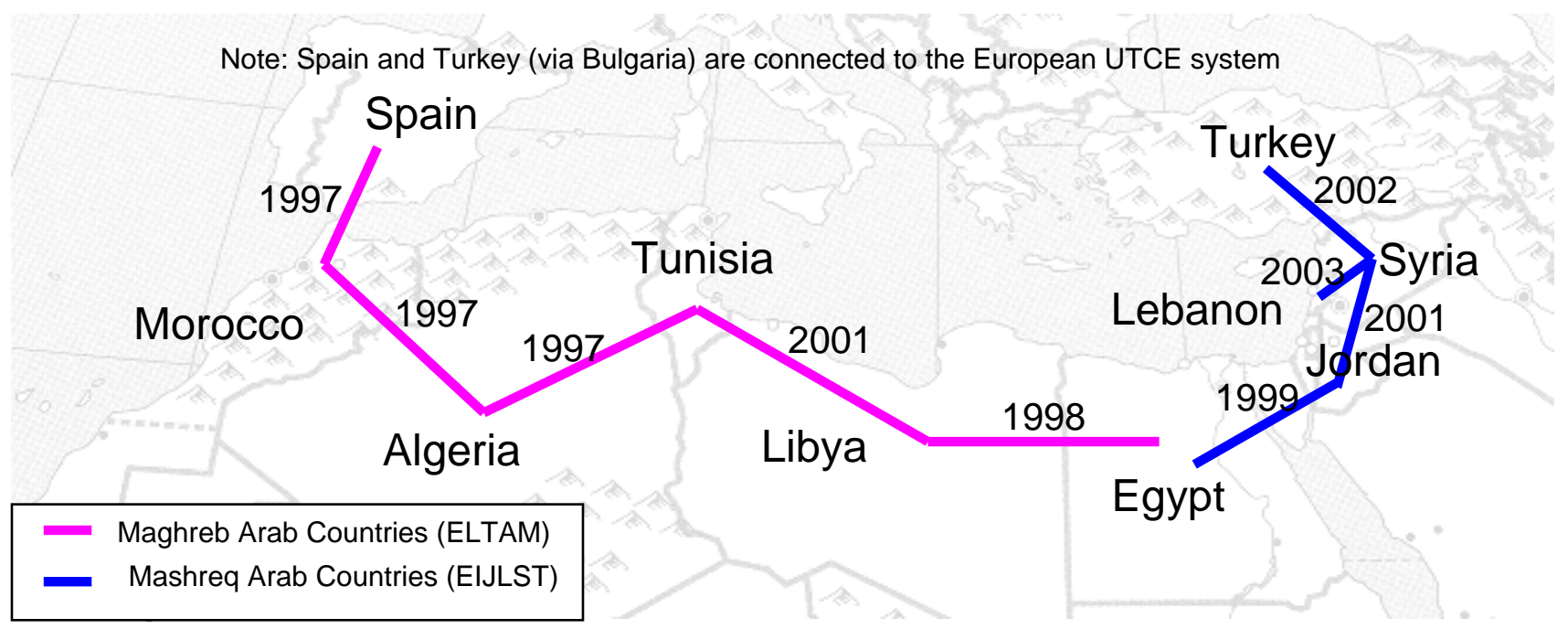

Figure 3. Interconnection of Electric Transmission Grids in the Middle East and North Africa. $^{506}$

Tunisia's national oil company, Enterprises Tunisienne d'Activités Petrolières (ETAP), was established in 1972 in order to manage the oil and natural gas exploration and production activities for the Tunisian government. Currently, the country produces about $81,530 \mathrm{bbl}$ per day of oil and consumes 89,000 bbl per day; but as noted above, Tunisia has limited refining capacity, so the country exports crude oil and imports refined petroleum products. Tunisia has 1.7 billion bbl of reserves, most of which are located in the Gulf of Gabes and the Ghadames Basin in the southern part of the country. ${ }^{507}$ (CIA Factbook 2007, EIA 2006)

\footnotetext{
${ }^{504}$ Société Tunisienne de l'Electricité et du Gas, http://www.steg.com.tn/en/accueil.html.

${ }^{505}$ Energy Information Administration. "Country Analysis Briefs: Arab Maghreb Union”, U.S. Department of Energy, April 2006. Accessed 1 June 2007. http://www.eia.doe.gov/emeu/cabs/morocco.html

506 “The Potential for Regionally Integrated Energy Development in Africa”, World Energy Council 2007. Accessed 21 May 2007. Dates shown are as listed in this source, which are likely dates when construction began. Other sources list various other dates of completion of construction, or when the grids came online. http://www.worldenergy.org/wec-geis/publications/reports/africa/cooperation/cooperation.asp

${ }^{507}$ Energy Information Administration. "Country Analysis Briefs: Arab Maghreb Union,” U. S. Department of Energy, April 2006. Accessed 18 May 2007. http://commercecan.ic.gc.ca/scdt/bizmap/interface2.nsf/vDownload/CABS_0005/\$file/maghreb.pdf
} 
According to the Energy Information Administration, Tunisia's domestic oil production is insufficient to satisfy domestic consumption demand. Consequently, the government is seeking to attract greater foreign investments for oil exploration. Several domestic projects are underway, including joint projects with several other nations and international companies, to explore for in-country oil resources. ETAP is also pursuing oil exploration overseas in small fields, including those in Syria, Iraq, Algeria, and Libya. Moreover, to compensate for the limited refining capacity of Tunisia's one refinery at Bizerte, the Tunisian Ministry of Industry and Energy has sought investments from private companies to build, own, and operate another facility at La Skhirra with a minimum capacity of 120,000 bbl per day, which would plan to begin operations in 2010 . (EIA 2006, U.S. Department of State 2006)

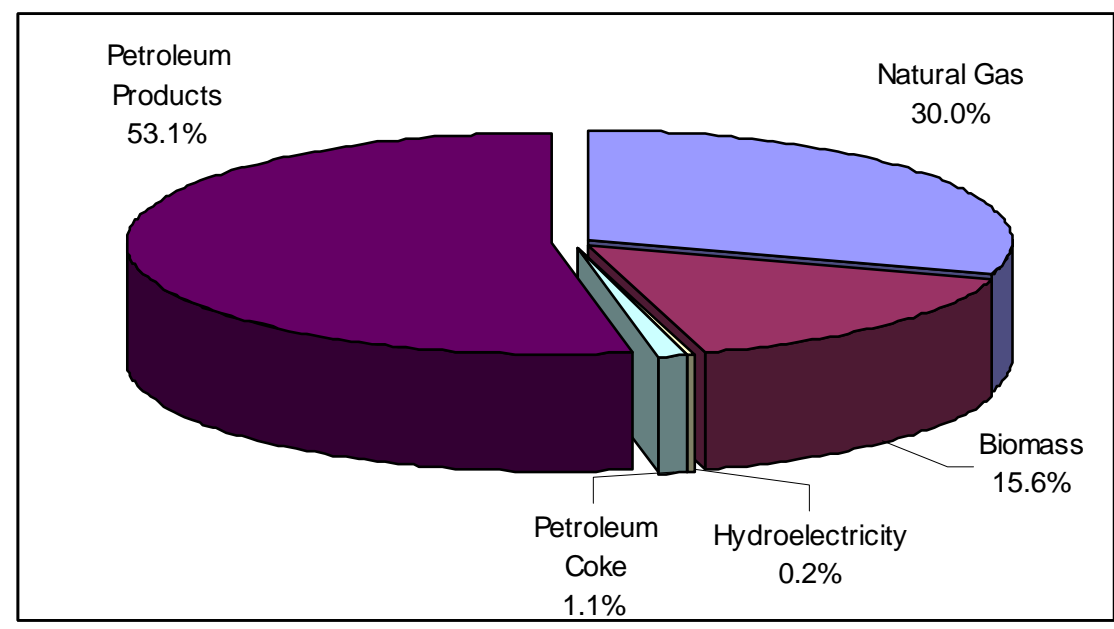

Figure 4. Primary Energy Consumption by Form of Energy in Tunisia in 2000. ${ }^{508}$

\section{Natural Gas}

Tunisia's natural gas production amounts to about 2.4 billion cubic meters annually. The majority of Tunisia's natural gas output comes from Miskar field, which is located about 80 miles offshore in the Gulf of Gabes. ${ }^{509}$ It is owned and operated by British Gas (BG), the main developer of Tunisia's natural gas and the biggest foreign investor in Tunisian industry. Tunisia is expected to have about 77.87 billion cubic meters of reserves.

Due to major increases in consumption of natural gas, estimated at a rate of nearly $10 \%$ annually from 1980 to 2000 , Tunisia now consumes 3.7 billion cubic meters of natural gas annually. ${ }^{510}$ Tunisia is increasingly turning to natural gas to meet domestic

\footnotetext{
${ }^{508}$ Missaoui, Rafik and Samir Amous. "Financing the Development of the Renewable Energy in the Mediterranean Region, Baseline Study for Tunisia", Division of Technology, Industry, and Economics, United Nations Environment Programme, May 2003. http://www.uneptie.org/energy/act/fin/medrep/MEDREP-\%20Tunisia\%20baseline.pdf ${ }^{509}$ Energy Information Administration. "Country Analysis Briefs: Arab Maghreb Union,” U. S. Department of Energy, April 2006. Accessed 18 May 2007. http://commercecan.ic.gc.ca/scdt/bizmap/interface2.nsf/vDownload/CABS_0005/\$file/maghreb.pdf ${ }_{510}$ Missaoui, Rafik and Samir Amous. "Financing the Development of the Renewable Energy in the Mediterranean Region, Baseline Study for Tunisia", Division of Technology, Industry, and Economics,
} 
energy demand, ${ }^{511}$ and STAG reports a significantly increased percentage of energy consumption from natural gas in the past few years.

Increased gas consumption has stemmed in part from increased availability of the resource through the Tran Mediterranean pipeline, which transports Algerian natural gas to Italy through Sicily. Through this pipeline, which has a 1,300 bfc per year capacity, Tunisia imports 1.3 billion cubic meters annually. Tunisia receives royalties of between 5.25 and $6.75 \%$ of the value of the gas transported. Expansions for the capacity of the Tunisian pipeline are planned for 2008, as well as a further expansion for 2012, bringing total capacity to at least 1,183 bfc per year. ${ }^{512}$ Tunisia does not export domestically produced natural gas. (CIA Factbook 2007)

\section{INTERNATIONAL TREATY COMMITMENTS AND IAEA COOPERATION}

\section{IAEA Membership and International Treaty Commitments}

Tunisia became a member of the IAEA in 1957 and has since signed and ratified the Treaty on the Non-Proliferation of Nuclear Weapons (NPT) on 26 February 1970. It signed a comprehensive safeguards agreement with the IAEA in 1989 and ratified it a year later. Tunisia became a signatory to the Limited (Partial) Test Ban Treaty in 1963; the country ratified this treaty 1965. After signing the Comprehensive Test Ban Treaty in 1996, Tunisia ratified it in 2004. Tunisia has signed an Additional Protocol to its Safeguards Agreement in 2005, but has not yet ratified the Protocol. 513, 514, 515, 516

Tunisia is making a distinct effort to establish a sufficient legal infrastructure for nuclear energy development, but the country still lacks certain critical elements of the necessary legal framework. Among important agreements to which Tunisia has not yet acceded are protocols and conventions regarding civil liability for nuclear damage, spent fuel and waste management, and the Convention on Nuclear Safety. (Tunisia signed the Convention on Nuclear Safety, but it has not yet entered into force). Significantly, multiple IAEA Technical Cooperation programs have been instituted in Tunisia to address some of these weaknesses in their nuclear infrastructure, including programs on nuclear safety and waste, as discussed further below. For a full list of Tunisia's

\footnotetext{
United Nations Environment Programme, May 2003.

http://www.uneptie.org/energy/act/fin/medrep/MEDREP-\%20Tunisia\%20baseline.pdf

${ }^{511}$ Energy Information Administration. "Country Analysis Briefs: Arab Maghreb Union," U. S. Department of Energy, April 2006. Accessed 18 May 2007.

http://commercecan.ic.gc.ca/scdt/bizmap/interface2.nsf/vDownload/CABS_0005/\$file/maghreb.pdf

${ }_{512}$ Ibid.

513 “2002 NPT Preparatory Committee: Tunisia”, 12 April 2002. NPT/CONF.2005/PC.1/3/Add.2. Accessed 17 May 2007. http://www.basicint.org/nuclear/NPT/2002prepcom/Rpts-SArab\&Tunis.htm

${ }^{514}$ Bureau of Verification, Compliance, and Implementation, U.S. Department of State. "Treaty Banning Nuclear Weapon Tests in the Atmosphere, in Outer Space, and Under Water." Accessed 17 May 2007. http://www.state.gov/t/ac/trt/4797.htm\#signatory

${ }^{515}$ CTBTO Preparatory Commission. "Status of Signature and Ratification." 2007. Accessed 17 May 2007. http://www.ctbto.org

${ }^{516}$ International Atomic Energy Agency. "Strengthened Safeguards System: Status of Additional Protocols," 22 March 2007. Accessed 17 May 2007.

http://www.iaea.org/OurWork/SV/Safeguards/sg_protocol.html
} 
commitments to multilateral conventions and safeguards agreements with the IAEA, see Appendix K.

\section{IAEA Technical Cooperation Projects}

Tunisia is currently participating in 10 national, 42 regional, and 7 interregional Technical Cooperation (TC) projects. These include human resource development, groundwater resource management, legislative assistance, nuclear security implementation, waste management, air pollution monitoring, nuclear medicine, agriculture, radiation protection, and control of radiation sources. ${ }^{517}$

The main areas of focus for Tunisia's TC program are food and agriculture, health, and water resources; this was especially the case for the program from 1997 until 2002. The 2005 Country Overview for Tunisia's TC program states, "The 2003-2004 approved core programme saw a shift in focus away from the traditional areas of agriculture and animal health to a broader programme covering energy planning, radiation processing, and nuclear instrumentation," including the establishment of an Electron Beam Irradiation Facility for Radiation Processing for medical and industrial applications. According to the Overview, the proposed TC program for 2005 to 2006 centers on nuclear analytical techniques, nuclear medicine, water resources management, and agriculture. Tunisia has also initiated the establishment of a neutron activation laboratory in partnership with the IAEA, and has worked to strengthen nuclear safety and public exposure control. Tunisia has expressed interest in purchasing a linear accelerator, though this is subject to budgetary constraints. ${ }^{518}$

\section{REGIONAL PROJECT POSSIBILITIES}

Tunisia has established good relations with the West while playing an active role in Arab and African regional bodies. The U.S. State Department notes that, "Tunisia has long been a voice for moderation and realism in the Middle East," and "Tunisia consistently has played a moderating role in the negotiations for a comprehensive Middle East peace."519 Though relations have occasionally been strained with its neighbors Algeria and Libya, Tunisia and Algeria resolved a longstanding border dispute in 1993 and have cooperated in the construction of the Tran Mediterranean natural gas pipeline. Also, since UN sanctions against Libya were lifted in 2003, Libya has become a major trading partner with Tunisia. Tunisia served as the headquarters of the Arab League from 1979 to 1990 and hosted the Palestine Liberation Organization's (PLO) headquarters from 1982 to 1993. (The PLO Political Department remains in Tunis.) For its part, the United States has very good relations with Tunisia, which date back more than 200 years. (U.S. Department of State 2006)

\footnotetext{
${ }^{517}$ International Atomic Energy Agency, "TC Africa: Member States, Information Records on Tunisia." Accessed 17 May 2007. http://www-tc.iaea.org/tcweb/regionalsites/africa/country/default.asp?cid=TUN ${ }^{518}$ International Atomic Energy Agency, “Country Overview for Tunisia, 2005.” Accessed 17 May 2007. http://www-tc.iaea.org/tcweb/regionalsites/africa/documents/TUN2005.pdf

${ }^{519}$ Bureau of Near Eastern Affairs. "Background Note: Tunisia," U.S. Department of State, October 2006. Accessed 14 May 2007. http://www.state.gov/r/pa/ei/bgn/5439.htm
} 
Tunisia has historically maintained high tariffs to protect domestic industries, but in recent years, has worked towards trade liberalization. In 1995, Tunisia signed an association agreement with the European Union, which has significantly lowered tariffs, and has agreed to set up a free trade zone with Egypt, Jordan, and Morocco. This zone is expected to expand to include ultimately ten Arab nations, forming the Great Arab Free Trade Zone. ${ }^{520}$ Furthermore, a framework for a U.S.-Tunisia trade agreement was also signed, and Tunisia has been party to the GATT since 1991. ${ }^{521}$ These close economic and political relations provide incentive for American assistance towards Tunisia's development efforts in nuclear technology for peaceful applications.

Because of Tunisia's close ties with other Maghreb and North African countries, collaboration with its neighbors would be greatly beneficial. Tunisia could further its nuclear knowledge by studying the nuclear research reactors of Egypt, and any electricity produced from a plant in the North African countries could be transported among the countries using the electrical grid already in process. Pooled resources of technology, manpower, capability, and financial ability with Libya, Algeria, Egypt, and Morocco would aid each country's goal to develop a dual-use plant for water desalination and electricity purposes.

\footnotetext{
${ }^{520}$ Energy Information Administration. “Country Analysis Briefs: Arab Maghreb Union,” U. S. Department of Energy, April 2006. Accessed 18 May 2007.

http://commercecan.ic.gc.ca/scdt/bizmap/interface2.nsf/vDownload/CABS_0005/\$file/maghreb.pdf

${ }^{521}$ Missaoui, Rafik and Samir Amous. "Financing the Development of the Renewable Energy in the Mediterranean Region, Baseline Study for Tunisia", Division of Technology, Industry, and Economics, United Nations Environment Programme, May 2003. http://www.uneptie.org/energy/act/fin/medrep/MEDREP_\%20Tunisia\%20baseline.pdf
} 


\section{UNITED ARAB EMIRATES}

Overview

The Trucial Coast was formed in 1853 when several Arab sheiks signed a treaty with the British. In 1971, six of these states, Abu Zaby, 'Ajman, Al Fujayrah, Ash Shariqah, Dubayy, and Umm al Qaywayn, declared independence and joined to form the United Arab Emirates (UAE); they were joined by a seventh state, Ras al-Khaimah, in early 1972. Today, since the discovery of oil about 30 years ago, the UAE has transformed from an impoverished barren nation to a modern state with a very high nominal GDP per capita of capita of $\$ 49,700$, compared to the world average of $\$ 10,000$, ranking $5^{\text {th }}$ in the world. ${ }^{522}$

The UAE has an open economy, and has directed largely effective efforts towards diversification; however, about $30 \%$ of the GDP is still based on oil and gas revenues, and the economy is highly dependent upon prices for these commodities. Recent high oil prices, strong liquidity, and cheap credit have yielded high annual GDP growth of $10 \%$ in recent years. The two largest emirates, Abu Dhabi and Dubai, provide over $80 \%$ of the UAE's income; Dubai in particular has become a central Middle East hub for trade and finance, and provides about $85 \%$ of the UAE's re-export trade. ${ }^{523}$ Dependence on a large expatriate workforce and oil are significant challenges to the UAE's long-term economical prospects.

The UAE's population of about 4.5 million people ranks the country $120^{\text {th }}$ in the world, but as of 1982 , less than $20 \%$ were UAE citizens. Immigrants include significant numbers of other Arabs, such as Palestinians, Egyptians, Jordanians, Yemenis, and Omanis, as well as many Iranians, Pakistanis, Indians, Bangledeshis, Afghanis, Filipinos, and west Europeans. The UAE's population is 96\% Muslim, and has a Shi'a minority of around $16 \%{ }^{524}$

Cumulatively, the area of the United Arab Emirates is slightly smaller than Maine, ranking $115^{\text {th }}$ among the world's nations. Very little of this land is arable, and the geography consists of a barren coastal plain with rolling sand dunes in an inland desert wasteland. Consequently, primary among environmental issues is a lack of natural freshwater resources, for which the UAE currently compensates by the use of desalination plants. Energy use in the UAE is quite high, at $10,362 \mathrm{kWh}$ per capita, compared to the world average of 2,962 $\mathrm{kW}$ and fairly comparable to the U.S.'s rate of 12,454 kWh consumed per capita. (Energy Information Administration, CIA Factbook 2007, U.S. Department of State 2006)

The UAE has oil and natural gas reserves that are among the largest in the world, but significant and steady increases in electricity use, as well as extremely limited water resources, have provided an incentive for the government to research alternative energy resources. The UAE does not yet have the technical or legislative infrastructure

\footnotetext{
522 Central Intelligence Agency. "United Arab Emirates," The World Factbook. Last updated 15 May 2007. Accessed 23 May 2007. https://www.cia.gov/library/publications/the-world-factbook/geos/ae.html

${ }^{523}$ Energy Information Administration. “United Arab Emirates”, U.S. Department of Energy. Accessed 4 June 2007. http://www.eia.doe.gov/emeu/cabs/UAE/Background.html

${ }^{524}$ Bureau of Near Eastern Affairs. "Background Note: United Arab Emirates," U.S. Department of State, October 2006. Accessed 24 May 2007. http://www.state.gov/r/pa/ei/bgn/5444.htm
} 
necessary for the development of a nuclear program, however. Thus, nuclear energy is still in preliminary planning phases. With IAEA guidance, tightly strengthened export controls, increased regulatory framework, and other improvements, the UAE could initiate a basic nuclear program. Collaboration with other Arab nations would aid in the process of developing a peaceful nuclear program to meet the country's electricity and desalination needs.

\section{NUCLEAR INFRASTRUCTURE/INTENTIONS}

\section{Infrastructure}

\section{Knowledge management}

The UAE's high population growth rate of about $4 \%$ is primarily due to immigration. Despite the constant influx of people, the UAE has a very low unemployment rate of only $2.4 \%$. A minimal $15 \%$ of the labor force, though, works in industry. The total population has a literacy rate of $77.9 \%$, and surprisingly, a higher rate of literacy is reported for women than for men ( $81.7 \%$ and $71.6 \%$, respectively). (CIA Factbook 2007)

It appears that only very limited nuclear research is being conducted in the UAE at present. No central institution exists for nuclear research or radiation management, though some coursework is offered in the university system. The United Arab Emirates University (UAEU) offers upper-level classes related to nuclear physics; it also has a program in medical physics which includes classes on nuclear medicine, including radiotherapy, dosimetry, and radiation protection. ${ }^{525}$ UAEU also houses a Central Laboratories Unit, which provides "analytical/testing services in the field of water quality analysis, environmental analysis, soil analysis, petroleum and petrochemical analysis, food \& feed analysis and material \& corrosion testing." 526 The Analytical Facilities contain a mass spectrometer, a scanning electron microscope, and equipment for nuclear magnetic resonance spectroscopy. The Health Medicine program at the Higher Colleges of Technology includes education on medical imaging. ${ }^{527}$

\section{Uranium Resources}

The UAE does not have any identified uranium deposits. ${ }^{528,529}$

\section{Nuclear Reactors and Fuel Facilities}

The UAE does not have any known nuclear reactors or conversion, enrichment, or fuel facilities. 530,531

\footnotetext{
525 Academic Programs and Curricula Catalog, United Arab Emirates University, 2003-2004. Accessed 4 June 2007. http://catalog.academics.uaeu.ac.ae/

${ }^{526}$ Central Laboratories Unit, United Arab Emirates University. http://www.uaeu.ac.ae/clu/

${ }^{527}$ Higher Colleges of Technology Academic Catalogue 2006-2007. Accessed 4 June 2007. http://css.hct.ac.ae/catalogues/catalogue06-07/view.asp

${ }^{528}$ Joint Report by the OECD Nuclear Energy Agency and the International Atomic Energy Agency. Uranium 2005:Resources, Production, and Demand, Paris: OECD Publishing, 2005. p. 215-9.

${ }^{529}$ Integrated Nuclear Fuel Cycle Information Systems, World Distribution of Uranium Deposits Database. International Atomic Energy Agency. 2003. Accessed 25 April 2007. http://www-nfcis.iaea.org/
} 


\section{$\underline{\text { Regulation }}$}

Most of the UAE's Technical Cooperation programs instituted with the IAEA and related to nuclear energy planning and preparation are managed by the Ministry of Energy, which has a Radiation Protection \& Control Department. ${ }^{532}$ This Department is also the IAEA contact point for guidance on the import and export of radioactive sources. ${ }^{533}$ Its specific responsibilities are not readily found in the public domain.

\section{Intentions}

As a member of the Gulf Cooperation Council (GCC), the UAE has demonstrated interest in developing a joint plan for nuclear energy generation in the near future. Though the GCC had previously shown only marginal interest in developing nuclear technologies, Saudi Arabia, Kuwait, the United Arab Emirates, Qatar, Bahrain, and Oman commissioned a feasibility study in December 2006 on employing nuclear technology for peaceful purposes in accord with international regulations and standards. The GCC Secretary General, Abderrahman Al-Attiyya of Qatar, told Gulf News in February 2007 of the Council's ambitious goal to begin construction of a nuclear power plant by 2009 . The countries plan to use nuclear power only for peaceful purposes, such as meeting increasing demands for electricity, water desalination, and agriculture. "AlAttiyya has said that the GCC desired to engage the IAEA in its program from the beginning since its involvement would make clear the GCC's commitment to pursuing 'a transparent process, within international standards,"' writes Richard Weitz of the Hudson Institute. ${ }^{534}$ In May 2007, an IAEA delegation began meeting with representatives of the six GCC member countries in order to discuss the implementation of IAEA regulations for the development of nuclear power. A preliminary report is scheduled to be submitted to GCC leaders at the next summit, which will take place in December 2007 in Oman. ${ }^{535}$ Despite Al-Attiyya's pronouncement, the Foreign Minister of Kuwait has predicted that it could take 12 to 15 years for the GCC to develop a nuclear power plant from December 2006, when they announced interest in nuclear energy. Though the GCC nations have more than sufficient domestic energy resources, they may be looking to provide a more energy-efficient method for nuclear desalination, to diversify energy resources, and to

530 Research Reactor Database. "Nuclear Research Reactors in the World." International Atomic Energy Agency, 1999. Accessed 4 June 2007. http://www.iaea.org/worldatom/rrdb/

${ }^{531}$ NFCIS, "List of Nuclear Fuel Cycle Facilities." International Atomic Energy Association, 2003. Last updated 31 January 2000. Accessed 8 May 2007. http://www-nfcis.iaea.org/Default.asp

${ }^{532}$ International Atomic Energy Agency, "IAEA - TC Projects by Country: United Arab Emirates." Accessed 24 May 2007. http://www-tc.iaea.org/tcweb/tcprogramme/projectsbycountry/default.asp 533 "IAEA Guidance on the Import and Export of Radioactive Sources," International Atomic Energy Agency, 30 April 2007. Accessed 4 June 2007. http://www-ns.iaea.org/downloads/rw/meetings/importexport-contact-points.pdf

${ }^{534}$ Weitz, Richard. "Gulf Cooperation Council Moves Forward with Nuclear Energy Plans", WMD Insights, April 2007. Accessed 7 May 2007. http://www.wmdinsights.com/I14/I14 ME3 GCCMovesForward.htm

${ }^{535}$ Qusti, Raid. "Preliminary Report on GCC Nuclear Energy by Year-End," Arab News, 22 May 2007. Accessed 4 June 2007. http:/www.arabnews.com/?page $=1 \&$ section $=0 \&$ article $=96485 \& \mathrm{~d}=22 \& \mathrm{~m}=5 \& \mathrm{y}=2007$ 
increase the proportion of oil exports. The UAE has already initiated some work in these areas, as described below.

The UAE's fresh water resources are extremely limited. Dubai, for instance, experienced three rainy days in 2003 with rainfall totaling $2.4 \mathrm{~mm} .^{536}$ The World Resources Institute reports that the UAE has no surface water production, no groundwater, and no internal renewable water resources. ${ }^{537}$ As UAE citizens consume about $647.6 \mathrm{~m}^{3}$ per capita of water annually, the primary source of potable water is desalination. ${ }^{538}$ Abu Dhabi's Water and Electricity Authority explains that desalination takes place predominantly alongside the generation of electricity in cogeneration stations, and water is transmitted through pipelines or, in remote areas, road tankers. The first desalination plant was in operation by 1970 ; installed desalination capacity increased from 4 million gallons per day in 1970 to 449 million gallons per day in 2003. By 2003, electricity generation capacity had concurrently reached 5,246 MW. ${ }^{539}$

Consumption rates of both water and electricity are rising rapidly with the UAE's economic development, particularly in Dubai. To compensate, Dubai is planning to build one of the world's largest power and desalination complexes, with generation capacity rivaling that of New York City. The plant's projected capabilities are 9,000 MW generating capacity of electricity and 600 million gallons per day of desalinated water. Even with this plant, because of demand rising at huge rates of 11 to $18 \%$ annually, the UAE will begin importing natural gas from Qatar in June 2007 in the "Dolphin Project" and may import electricity in the near future from Iran via an underwater cable. ${ }^{540}$ Other plans are under way for more desalination plants, and a campaign to reduce water consumption has been undertaken in Dubai. ${ }^{541}$

Nuclear desalination may be an attractive prospect for the UAE, because water desalination is an energy-intensive process (See Appendix Q). The UAE is currently conducting a Technical Cooperation project with the IAEA on a feasibility study for a nuclear desalination plant. ${ }^{542}$

Because Emirati interest in nuclear energy is fairly recent, a comprehensive policy has not yet been enumerated by the government. However, there is significant

\footnotetext{
${ }^{536}$ Agriculture Statistics Year Books 2003: Metrological Statistics. "Monthly Total Rainfall M.M. \& Number of Rainy Days for 2003." UAE - Environmental \& Agricultural Information Centre, Ministry of Environment \& Water. Accessed 5 June 2007. http://www.uae.gov.ae/uaeagricent/statistics/asyearbook03.stm

537 "Water Resources and Freshwater Ecosystems-- United Arab Emirates", World Resources Institute, 2003. Accessed 4 June 2007. http://earthtrends.wri.org/pdf_library/country_profiles/wat_cou_784.pdf ${ }^{538}$ Al-Mutaz, Ibrahim S. "Potential of nuclear desalination in the Arabian Gulf countries," International Journal of Nuclear Desalination, Vol. 135, 2001. Accessed 11 June 2007. http://www.desline.com/articoli/4048.pdf

539 "Water and Electricity", Abu Dhabi Water and Electricity Authority, 2007. Accessed 4 June 2007. http://www.adwea.com/en/weSystem/

540 "Dubai plans to build giant power and water project," UAE Interact, 26 May 2007. Accessed 4 June 2007. http://uaeinteract.com/news/default.asp?ID=225

541 “Today's News Stories”, UAE Interact, 26 May 2007. Accessed 4 June 2007. http://uaeinteract.com/news/default.asp?ID=225

${ }^{542}$ International Atomic Energy Agency, "IAEA - TC Projects by Country: United Arab Emirates." UAE/4/002. Accessed 4 June 2007. http://wwwtc.iaea.org/tcweb/tcprogramme/projectsbycountry/default.asp
} 
demand for efficient desalination processes and the country would benefit from a dualuse nuclear power plant, which would provide a domestic source of both electricity and potable water. This could be particularly advantageous in light of UN predictions that the UAE may suffer from power shortages by $2012 .{ }^{543}$ The UAE has not demonstrated any interest in nuclear weapons and has sought only peaceful applications of nuclear technology, primarily in the fields of nuclear desalination and nuclear medicine. ${ }^{544}$ Regarding the collaborative GCC program, many of the details of the nuclear initiative have yet to be addressed, such as a source of fuel, location, and financing; the program is in its early stages. At an early March summit in 2007, the Council issued a joint statement affirming their governments' desire for a WMD-free zone in the Middle East, calling for a peaceful solution regarding Iran's nuclear program, demanding Israel's accession to the Treaty on the Nonproliferation of Nuclear Weapons (NPT), and declaring their continued interest and pursuit of a nuclear research and development program for peaceful energy purposes. (Weitz 2007)

The most significant proliferation concern involving the UAE regards its trade flows. The UAE lies in the Arab Peninsula bordering the Gulf of Oman and the Persian Gulf, between Oman and Saudi Arabia. Its strategic location along southern side of the Strait of Hormuz makes it a vital transit point for world crude oil, as well as other trade routes. The UAE has been a member of the World Trade Organization (WTO) since 1995, and has one of the most open economies in the region, and the country's ports are the site for significant amounts of Middle East trade. ${ }^{545}$

Emirati companies, however, have been linked to the re-export of illicit nuclear material. A computer company, based in the UAE, was identified by U.S. President George Bush as serving as a middleman for Libya's imports of nuclear equipment; ${ }^{546}$ consequently, in April 2004, the UAE government froze the company's assets. ${ }^{547}$ As recently as 2006, the U.S. Treasury Department has been monitoring Dubai's financial transactions for the possibility of WMD proliferation to countries such as Libya and Iran. The Global Security Newswire reports the Treasury's concerns over "Dubai-based activities of the Dutch bank ABN Amro that in December 2005 led the United States to fine the bank $\$ 80$ million for improper transactions with Libyan and Iranian clients." ${ }^{548}$ In comments regarding a recent deal that gave an Arab company control over the Dubai ports, Representative Duncan Hunter (R-Calif.) said, "United Arab Emirates officials have been instrumental in the transshipment of nuclear materials and weapons of mass destruction components...United Arab Emirates officials and private companies have

\footnotetext{
543 "Dubai to harness sun and wind to meet power needs," UAE Interact, 30 March 2007. Accessed 4 June 2007. http://www.uaeinteract.com/news/default.asp?ID=231

${ }^{544}$ Janardhan, Meena S. "Enhancing Nuclear Energy to Ease Water Shortage, Save Lives," Asia Water Wire 2005. Accessed 4 June 2007. http://www.asiawaterwire.net/node/97

${ }^{545}$ Energy Information Administration. "United Arab Emirates", U.S. Department of Energy. Accessed 4 June 2007. http://www.eia.doe.gov/emeu/cabs/UAE/Background.html

546 "Countries, Companies Deny Roles in International Nuclear Black Market." Global Security Newswire, 13 February 2004, Nuclear Threat Initiative. Accessed 4 June 2007. http://www.nti.org/d newswire/issues/2004/2/13/4a823659-af2c-4146-b6c0-c710169d30b1.html

${ }^{547}$ Bonner, Raymond. "World Briefing - Middle East: United Arab Emirates: Nuclear Network Inquiry." The New York Times, 6 April 2004. Accessed 4 June 2007. http://www.nytimes.com/

${ }^{548}$ Fiorill, Joe. "U.S. Watches Dubai Banks for Proliferation Ties", Global Security Newswire, Nuclear Threat Initiative, 3 March 2006. Accessed 4 June 2007. http://www.nti.org/d_newswire/issues/2006_2_16.html\#DB053BB4
} 
regularly waved-through or turned a blind eye to the shipment of nuclear triggers to Pakistan and nerve gas precursors to Iran." 549

Moreover, concerns have arisen over the fact that Dubai plays an important role in Iranian economic life by serving as a major trans-shipping and financial center. Iran is one of Dubai's main trading partners, accounting for 20 to $30 \%$ of Dubai's business. ${ }^{550}$ A Nuclear Threat Initiative summary reported the 1996 estimate of trade officials that \$1 billion worth of U.S. goods exported to Dubai, or half of the UAE's total imports from the United States, ended up in Iran. The summary concluded, "The UAE lacks the necessary controls to monitor transfers of missile, chemical, and nuclear materials." Iran recently offered to share its nuclear expertise with the GCC states, reportedly for peaceful nuclear energy purposes. ${ }^{552}$

On the other hand, in May 2005 Dubai joined the National Nuclear Security Administration's Megaports Initiative, becoming the first Middle Eastern government to participate in the program, which seeks to deter nuclear terrorists and to detect and to interdict shipments of potentially harmful radioactive materials. ${ }^{553,554}$ Oman, Egypt, and Israel have since joined the Megaports Initiative as well. Furthermore, the UAE's security concerns are closely tied to that of the United States. The U.S. Department of State relates that, following Iraq's 1990 invasion and attempted annexation of Kuwait, the UAE has sought to rely on the GCC, the United States, and other Western allies for its security. 555

Emirati technology does not appear to include much capable of contributing to develop a nuclear weapon program, and government policy does not indicate any public intention to pursue such a program. A proliferation risk exists through the UAE's reexport system, but by cracking down on customs violations with international help and by joining the Megaports Initiative, the UAE seems to be taking steps towards combating this proliferation risk. Stronger export controls and increased monitoring for companies that pose as a front for illicit transport of goods will decrease concerns over nuclear proliferation through the ports of the UAE.

\section{ECONOMIC}

\footnotetext{
549 "Security Concerns Prompt Delay of Port Deal," Global Security Newswire, Nuclear Threat Initiative, 3 March 2006. Accessed 4 June 2007. http://www.nti.org/d_newswire/issues/2006/3/3/61dec979-e8934a29-a766-be8a65c4abbf.html

${ }^{550}$ Energy Information Administration. "United Arab Emirates", U.S. Department of Energy. Accessed 4 June 2007. http://www.eia.doe.gov/emeu/cabs/UAE/Background.html

${ }^{551}$ Abstract, Nuclear Threat Initiative. “Country Profile: United Arab Emirates”, Risk Report, March 1996. Accessed 4 June 2007. http://www.nti.org/db/missile/1996/m9606269.htm

${ }_{552}$ Bibbo', Barbara. "Iran offers to share nuclear expertise with GCC states", Gulf News, 13 April 2007. Accessed 4 June 2007. http://archive.gulfnews.com/articles/07/04/13/10117924.html

${ }^{553}$ Wisconsin Project on Nuclear Arms Control. "United Arab Emirates Transshipment Milestones - 19712005”, The Risk Report, Vol. 11 No. 4, July-August 2005. Accessed 4 June 2007. http://www.wisconsinproject.org/countries/dubai/transshipment-milestones.html

${ }^{554}$ Megaports Initiative, National Nuclear Security Administration. http://www.nnsa.doe.gov/megaports_initiative.htm

${ }^{555}$ Bureau of Near Eastern Affairs. "Background Note: United Arab Emirates," U.S. Department of State, October 2006. Accessed 24 May 2007. http://www.state.gov/r/pa/ei/bgn/5444.htm
} 


\section{Electricity}

The UAE produces 49.52 billion kWh of electricity, entirely from thermal generation plants. Domestic consumption amounts to 46.05 billion $\mathrm{kWh}$, and the UAE does not currently import or export electricity. (CIA Factbook 2007)

Because of high initial costs for alternative energy resources and adequate oil and gas resources for thermal generation plants, the UAE has had as yet insufficient incentives for developing alternative energy options, although initial studies have been conducted on solar power and wind power options. Sheikh Mohammed bin Rashid Al Maktoum, Ruler of Dubai, said part of the high energy use rate was due to inefficiencies, and that about $14 \%$ of peak electricity demand could be saved by 2015 through a demand management program and by supplementing current electrical production with solar energy. The first solar energy plant, with a $100 \mathrm{MW}$ capacity, is scheduled to be built in Abu Dhabi. Other research plans have been initiated for a solar-powered desalination plant. The Gulf Research Centre has argued that the UAE does not have sufficient quantities of natural gas, and solar power could be a natural choice to meet power demand while allowing greater quantities of oil to be exported. Regarding wind power, a feasibility study found that three wind farms in Fujairah with a total $66 \mathrm{MW}$ capability could be a viable option in helping to meet demand for electricity in the UAE. Though these studies and others are being conducted on solar energy and wind power, such options have yet to be implemented. ${ }^{556}$ (UAE Interact)

The UAE is also seeking to meet domestic energy needs through connecting the emirates' electrical grids. Thus far, the electricity networks of Abu Dhabi, Dubai, and Sharjah have been interconnected. Plans are under way for a nation-wide power grid which will reduce operations costs and create a reserve power capacity for emergency use. $_{558}^{557}$ Interconnections with other members of the GCC are also planned for the future.

\section{Oil}

In 2005, the UAE produced 2.54 million bbl per day of oil, of which Abu Dhabi produced approximately $94 \%$. The country is consequently the $11^{\text {th }}$ largest producer of oil in the world. Residents consume 400,000 bbl per day, and the UAE exports amount to about 2.5 million bbl per day. The country does not import oil. (CIA Factbook 2007, U.S. Department of State 2006)

Abu Dhabi joined OPEC in the late 1960's, and with the formation of the UAE, the other emirates gained representation in OPEC as well. Because of its predominant oil production, Abu Dhabi acts as a swing producer, altering its production to conform with OPEC quota changes. This leaves Dubai and the other emirates, with their much smaller output, largely unaffected. Oil is projected to be the backbone of the UAE's economy for

\footnotetext{
556 “The Country \& The Environment - Solar Energy”, Today’s News Stories, UAE Interact. Accessed 4 June 2007. http://www.uaeinteract.com/news/default.asp?ID=231

557 "Second phase of national power grid inaugurated" UAE Interact, 29 May 2007. Accessed 4 June 2007. http://uaeinteract.com/news/default.asp?ID=225

558 "Water and Electricity", Abu Dhabi Water and Electricity Authority, 2007. Accessed 4 June 2007. http://www.adwea.com/en/weSystem/
} 
decades to come. ${ }^{559}$ The country's proved reserves of 98.7 billion bbl amount to nearly $10 \%$ of the world's total reserves, and expansions have been planned in almost all the existing oil fields within the UAE. ${ }^{560}$ (Butt 2001)

\section{Natural Gas}

The UAE produces 46.29 billion cubic meters of natural gas annually and consumes 40.31 billion cubic meters. It imports 1.2 billion cubic meters and exports 7.18 billion cubic meters. The UAE has the fifth largest natural gas reserves in the world with over 6 trillion cubic meters, most of which is located in Abu Dhabi. (CIA Factbook 2007)

Increased domestic consumption of energy and growing demand for oil has provided incentives for the UAE to increase the percentage of domestic natural gas consumption. Natural gas consumption in Abu Dhabi has doubled in the last decade. ${ }^{561}$ As Dubai's natural gas supplies are also limited, and the Dolphin Project has been developed to supply the United Arab Emirates with natural gas from Qatar. This \$3.5 billion pipeline project is designed to export 3.2 billion cubic feet per day of natural gas to the UAE over the next 25 years. According to one analyst, "The pipeline is seen as crucial in UAE to meet its growing population's increasing energy demand," and most of the UAE's increased natural gas needs in the next decade are expected to be satisfied with imported natural gas from Qatar. ${ }^{562}$

\section{INTERNATIONAL TREATY COMMITMENTS AND IAEA COOPERATION}

\section{International Treaties and Agreements}

The UAE became a member of the IAEA in 1976, and has since signed and ratified several international conventions and agreements. It acceded to the Treaty on the Non-Proliferation of Nuclear Weapons (NPT) on 26 September 1995. The UAE does not appear to have signed the Limited (Partial) Test Ban Treaty, but it did sign the Comprehensive Test Ban Treaty in 1996 and ratified it in 2000. Though the UAE has a comprehensive Safeguards Agreement with the IAEA, which entered into force 9

\footnotetext{
${ }^{559}$ Butt, Gerald. "Oil and Gas in the UAE," United Arab Emirates: A New Perspective, Ibrahim Al-Abed and Peter Hellyer, Ed. 2001. Accessed 4 June 2007. http://uaeinteract.com/uaeint_misc/pdf/perspectives/00.pdf

560 "UAE has the fifth largest natural gas reserves in the world," Alexander's Gas \& Oil Connections, News \& Trends: Middle East, Vol. 12, Issue 8, 24 April 2007. Accessed 4 June 2007. http://www.gasandoil.com/goc/news/ntm71704.htm

${ }^{561}$ Energy Information Administration. "United Arab Emirates: Oil”, U.S. Department of Energy, June 2006. Accessed 14 June 2007. http:/www.eia.doe.gov/emeu/cabs/UAE/Oil.html

562 "UAE has the fifth largest natural gas reserves in the world," Alexander's Gas \& Oil Connections, News \& Trends: Middle East, Vol. 12, Issue 8, 24 April 2007. Accessed 4 June 2007. http://www.gasandoil.com/goc/news/ntm71704.htm
} 
October 2003, it has not signed an Additional Protocol. The UAE has qualified and has been approved for the Small Quantities Protocol as well. ${ }^{563,564,565,566,567}$

The UAE has little of the legal framework required for a nuclear research or power program. This is not surprising, however, considering its current limited nuclear program. Among important agreements to which the UAE has not yet acceded are protocols and conventions regarding civil liability for nuclear damage, spent fuel and waste management, the Privileges and Immunities of the IAEA, and the Convention on Nuclear Safety. However, their signature and accession to a safeguards agreement with the IAEA in 2003 is significant. For a full list of the UAE's commitments to multilateral conventions and safeguards agreements with the IAEA, see Appendix L.

\section{IAEA Technical Cooperation Projects}

The UAE is involved in six active Technical Cooperation (TC) Projects with the IAEA, and has completed ten projects since joining the IAEA in 1976. A Nuclear Energy Planning program was first initiated as early as 1977, and currently TC projects include a feasibility study for a nuclear power and water desalination plant, a feasibility study on waste storage, emergency preparedness and response, and radiation protection for patients. The UAE has also completed TC projects on nuclear medicine, isotopes in hydrology, and radiation protection. A project on Human Resources Development and Nuclear Technology Support was originally started in 1997 and cancelled a year later, but it was restarted in $2007 .{ }^{568}$

\section{REGIONAL PROJECT POSSIBILITIES}

Private commercial ties between the United States and the United Arab Emirates, especially in petroleum, have developed into friendly international relations, including security assistance. The U.S. Department of State has lauded the UAE for its contributions to the continued security and stability of the Gulf and the Straits of

\footnotetext{
${ }^{563}$ Federation of American Scientists. Signatories and Parties to the Treaty on the Non-Proliferation of Nuclear Weapons. 3 December 1998. Accessed 24 May 2007.

http://www.fas.org/nuke/control/npt/text/npt3.htm

${ }^{564}$ Bureau of Verification, Compliance, and Implementation, U.S. Department of State. "Treaty Banning Nuclear Weapon Tests in the Atmosphere, in Outer Space, and Under Water.” Accessed 17 May 2007. http://www.state.gov/t/ac/trt/4797.htm\#signatory

${ }^{565}$ CTBTO Preparatory Commission. "Status of Signature and Ratification." 2007. Accessed 17 May 2007. http://www.ctbto.org

${ }^{566}$ International Atomic Energy Agency. "Safeguards Current Status”, 16 May 2007. Accessed 24 May 2007. http://www.iaea.org/OurWork/SV/Safeguards/sir table.pdf

${ }^{567}$ International Atomic Energy Agency. "Strengthened Safeguards System: Status of Additional Protocols," 22 March 2007. Accessed 17 May 2007. http://www.iaea.org/OurWork/SV/Safeguards/sg_protocol.html

${ }^{568}$ International Atomic Energy Agency, "IAEA - TC Projects by Country: United Arab Emirates." Accessed 24 May 2007. http://www-tc.iaea.org/tcweb/tcprogramme/projectsbycountry/default.asp
} 
Hormuz, stating that the UAE is a leading partner in the campaign against terrorism, and has provided military, diplomatic, and financial assistance since September 11, 2001. ${ }^{569}$ The Ministry of Finance and Industry states that, in the country's international relations, the UAE seeks close relations with Arab neighbors. "The GCC... is a central component of UAE foreign policy, especially its continuous efforts to encourage regional stability." with other GCC members, or at least with other Arab nations, such as Egypt. Because the UAE still lacks much of the technical and legislative framework for any nuclear program, it would be greatly beneficial for the country to cooperate with a more advanced nation in nuclear technology, like Egypt, in training and in infrastructure development prior to the establishment of nuclear research and development. Nuclear energy is likely not in the UAE's near future, but with proper guidance and oversight, a safe and peaceful program could be developed within the next several decades.

\footnotetext{
${ }^{569}$ Bureau of Near Eastern Affairs. "Background Note: United Arab Emirates," U.S. Department of State, October 2006. Accessed 4 June 2007. http://www.state.gov/r/pa/ei/bgn/5444.htm

570 "International Relations", Ministry of Finance and Investment.

http://www.uae.gov.ae/Government/int_relations.htm
} 


\section{KUWAIT}

\section{Overview}

A small country located on the Persian Gulf between Saudi Arabia and Iraq, Kuwait declared independence from the British in 1961. The country was invaded by Iraq in August 1990, and was liberated in February 1991 by US-led UN coalition forces. Kuwait's economy is heavily dependent on oil exports, and the destruction of oil fields in 1990-91 hurt economic growth. The government, though, invested enormous funds in revitalizing the industry, and oil fields resumed former production capacity within a few years. Kuwait has a relatively open economy, but with little diversification. Petroleum accounts for nearly half of GDP, $95 \%$ of export revenues, and $80 \%$ of government income. High oil prices have yielded strong economic growth rates since about 2003, but this has also abated pressure for economic reform, resulting in little focused government action in this regard. Kuwait's prosperity is reflected by its nominal GDP per capita, which ranks $51^{\text {st }}$ in the world by nominal GDP per capita with $\$ 21,600$, over twice the world average of $\$ 10,000$. The country also has a very high energy consumption of around 15,000 kWh per capita, compared to the world average of 2,962 kW and greater than the U.S. rate of $12,454 \mathrm{kWh}$ consumed per capita. Kuwait spends $5.3 \%$ of its GDP on military expenditures, ranking $16^{\text {th }}$ in the world in this respect. Kuwait is a major United States ally and U.S. troops and weapons have been based in the country since the first Gulf War. ${ }^{571}$

With an area slightly smaller than New Jersey, Kuwait has vast oil resources amounting to about $10 \%$ of world reserves, but only about $1 \%$ of the land is able to be cultivated for agriculture. Limited natural fresh water resources are a major environmental concern, and the Kuwaitis use "some of world's largest and most sophisticated desalination facilities" for potable water production. ${ }^{572}$ About $75 \%$ of Kuwait's potable water must be distilled or imported.

Over $90 \%$ of Kuwait's population, just over 2.5 million people, live within a 500 $\mathrm{km}^{2}$ area surrounding Kuwait City and its harbor. ${ }^{573}$ More than half the population is non-Kuwaiti, and the large population growth rate of 3.6\% results from an influx of many immigrants. However, Kuwait maintains a very low unemployment rate of $2.2 \%$. Most $(85 \%)$ of the population are Muslims, of which $70 \%$ are Sunni and $30 \%$ are Shi'a. (CIA Factbook 2007, U.S. Department of State 2007)

Kuwait's domestic nuclear knowledge base seems very basic, but it is easy for Kuwaiti citizens to obtain nuclear education abroad. No uranium resources, reactors, or fuel facilities are found in Kuwait, and there appears to be no relevant government regulation. Limited water resources force the country to rely on desalination for potable water, so nuclear desalination and electricity generation would become major goals of any future nuclear program. Kuwait projects that it will need new electricity generating

\footnotetext{
571 "NATO experts assess Kuwait's nuclear emergency contingency plans," Associated Press in International Herald Tribune, 6 May 2007. Accessed 5 June 2007. http:/www.iht.com/articles/ap/2007/05/06/africa/ME-GEN-Kuwait-NATO-Nuclear.php

${ }^{572}$ Central Intelligence Agency. "Kuwait," The World Factbook. Last updated 31 May 2007. Accessed 5 June 2007. https:/www.cia.gov/library/publications/the-world-factbook/geos/ku.html

${ }^{573}$ Bureau of Near Eastern Affairs. "Background Note: Kuwait," U.S. Department of State, May 2007. Accessed 5 June 2007. http://www.state.gov/r/pa/ei/bgn/35876.htm
} 
facilities in the near future to compensate for significant increases in demand, but plans on using imported natural gas for these facilities and projects that a nuclear power program is likely to be at least a decade away, even with Gulf Cooperation Council collaboration.

\section{NUCLEAR INFRASTRUCTURE/INTENTIONS}

\section{Infrastructure}

\section{Knowledge management}

Kuwait has a highly educated population with one of the strongest literacy rates in the Arab world, with over $93 \%$ of the population age 15 and older who can read and write. A contributing factor is free government education, including university, for all Kuwaiti citizens. About half the population works in industry and the other half works in services. Non-Kuwaitis represent about $80 \%$ of the labor force. (CIA Factbook 2007, U.S. Department of State 2006)

Limited nuclear education and nuclear research is currently conducted in Kuwait. In 1987, an engineer named 'Abd-al-Hamid 'Abd-al-Rasul Faraj submitted a study on the introduction of a nuclear program in Kuwait to the University of Kuwait. The study called for the development of research reactors, enriched uranium reserves, and other aspects, and expressed concerns about nuclear safety. ${ }^{574}$ Though some studies have been conducted on the feasibility and prospects for nuclear power, there is no central nuclear research body or regulatory agency today. The Physics Department of Kuwait University offers one upper-level course on Nuclear Physics, which covers nuclear reactions and cross-sections, particle accelerators and neutron generators, nuclear models, nuclear fission and elementary reactor theory, nuclear fusion, and radiation detection and dosimetry. ${ }^{575}$ The Faculty of Science also houses a "Centre of Researches in Environmental Radiation." ${ }^{576}$ Research on mass chain evaluation has been conducted at the Kuwait Nuclear Data Center for the past few years, but this seems to be the only research carried out at this facility. ${ }^{577}$ The Kuwait Institute for Scientific Research is the main research organization of the country; it conducts research on desalination options and has listed one nuclear-related anticipated project on "Nuclear techniques for measuring environmental radioactivity." center on effects of depleted uranium (DU) used in the 1991 Gulf War and on repercussions of Iran's nuclear program.

\footnotetext{
574 “Requirements for Nuclear Research Development Assessed”, Worldwide Report, 21 January 1987. Nuclear Threat Initiative Abstract. Accessed 5 June 2007. http://www.nti.org/db/nuclear/1987/n8701897.htm

${ }^{575}$ Course Catalogue and Description, Physics Department, Kuwait University. http://physics.kuniv.edu.kw/

${ }^{576}$ Departments, Faculty of Science, Kuwait University. http://www.science.kuniv.edu.kw/Units.xphp?Language=En

${ }^{577}$ Farhan, Ameenah. Status Report, Kuwait Nuclear Data Center, Kuwait University, June 2005. Accessed 6 June 2007. http://www.physics.mcmaster.ca/ balraj/nsdd2005/reports/kuwait_rep.pdf ${ }^{578}$ Research and Development: Anticipated Projects, Kuwait Institute for Scientific Research. http://www.kisr.edu.kw/research_anticipated.asp
} 
Kuwait's nuclear education programs seem to have a stronger focus on nuclear medicine than research, though its nuclear medicine programs are still quite small. The Ministry of Health has established a postgraduate training program in Nuclear Medicine and another in Radiology at the Kuwait Institute for Medical Specialization under the Ministry of Health. ${ }^{579}$ Mubarak Al-Kabeer Hospital in Kuwait houses the Kuwait Center for Specialised Surgery, which includes a Nuclear Medicine Department. At Kuwait University, a nuclear medicine technology program was instituted in 1983 as part of the department of Radiologic Sciences. The program graduates about 5 or 6 nuclear medicine technologists annually. ${ }^{580}$

Lawrence Livermore National Laboratory collaborates with the Kuwait Institute for Scientific Research (KISR) under a National Nuclear Security Administration project. KISR runs the eight stations of the Kuwait National Seismic Network, which is used to collect seismic data for nuclear explosion monitoring. ${ }^{581}$

\section{Uranium Resources}

Kuwait does not have any identified uranium deposits. ${ }^{582,583}$

Nuclear Reactors and Fuel Facilities

Kuwait does not have any known nuclear reactors or conversion, enrichment, or fuel facilities. ${ }^{584,585}$

\section{Regulation}

The Radiation Protection Department of Kuwait's Ministry of Health works with the IAEA on issues of dosimetry, and seems to be the main governmental organization that addresses environmental radiation. No official regulatory agencies are known for other nuclear projects.

\section{Intentions}

Kuwait began researching nuclear power in $1976,{ }^{586}$ but had reportedly decided by 1986 that nuclear energy was not a feasible option. The country was deemed too small, and a nuclear project would require too much dependence on foreign

\footnotetext{
${ }^{579}$ Postgraduate Training Program, Kuwait Institute for Medical Specialization, http://www.kims.org.kw/

${ }^{580}$ Ballani, Nasser. "Nuclear medicine education in Kuwait", Radiologic Technology, May 2002.

${ }^{581}$ Rodgers, Arthur J. and Abdullah M.S. Al-Amri. "Seismic Data for Nuclear Explosion Monitoring in the Arabian Peninsula," Lawrence Livermore National Laboratory and King Saud University, July 2004. Accessed 5 June 2007. http://www.llnl.gov/tid/lof/documents/pdf/309369.pdf

582 Joint Report by the OECD Nuclear Energy Agency and the International Atomic Energy Agency. Uranium 2005:Resources, Production, and Demand, Paris: OECD Publishing, 2005. p. 215-9.

${ }^{583}$ Integrated Nuclear Fuel Cycle Information Systems, World Distribution of Uranium Deposits Database. International Atomic Energy Agency. 2003. Accessed 5 June 2007. http://www-nfcis.iaea.org/

584 Research Reactor Database. "Nuclear Research Reactors in the World." International Atomic Energy Agency, 1999. Accessed 5 June 2007. http://www.iaea.org/worldatom/rrdb/

${ }^{585}$ NFCIS, "List of Nuclear Fuel Cycle Facilities." International Atomic Energy Association, 2003. Last updated 31 January 2000. Accessed 5 June 2007. http://www-nfcis.iaea.org/Default.asp

${ }^{586}$ International Atomic Energy Agency, "IAEA - TC Projects by Country: Kuwait." Accessed 5 June 2007. http:/www-tc.iaea.org/tcweb/tcprogramme/projectsbycountry/default.asp
} 
technology. ${ }^{587}$ As a member of the Gulf Cooperation Council (GCC), though, Kuwait has recently shown interest in developing a joint plan for nuclear energy generation in the near future. Though the GCC had previously shown only marginal interest in developing nuclear technologies, Saudi Arabia, Kuwait, the United Arab Emirates, Qatar, Bahrain, and Oman commissioned a feasibility study in December 2006 on employing nuclear technology for peaceful purposes in accord with international regulations and standards. The GCC Secretary General, Abderrahman Al-Attiyya of Qatar, told Gulf News in February 2007 of the Council's ambitious goal to begin construction of a nuclear power plant by 2009. The countries plan to use nuclear power only for legal purposes, such as meeting increasing demands for electricity, water desalination, and agriculture. "AlAttiyya has said that the GCC desired to engage the IAEA in its program from the beginning since its involvement would make clear the GCC's commitment to pursuing 'a transparent process, within international standards," writes Richard Weitz of the Hudson Institute. ${ }^{58}$ In May 2007, an IAEA delegation began meeting with representatives of the six GCC member countries in order to discuss the implementation of IAEA regulations for the development of nuclear power. A preliminary report is scheduled to be submitted to GCC leaders at the next summit, which will take place in December 2007 in Oman. ${ }^{589}$

Despite Al-Attiyya's pronouncement, Kuwait's foreign minister has predicted that it could take 12 to 15 years for the GCC to develop a nuclear power plant from the time of the announcement of interest in nuclear energy in December 2006. Though GCC nations have more than sufficient domestic energy resources, they may be looking to diversify energy resources, to increase the proportion of oil exports, and to provide a more energy-efficient method for nuclear desalination. In particular, Kuwait's increasing electricity demand is projected to soon require more generating capabilities, and Kuwait is looking towards nuclear power as a viable option. Natural gas and oil currently supply its electricity generating needs, but Kuwait's desire to export a larger percentage of oil production for revenue has initiated interest in alternative sources of energy.

Moreover, Kuwait's fresh water resources are extremely limited. Kuwait has very little rainfall: an average of 106 to $134 \mathrm{~mm}$ per year falls over the entire country. No permanent surface water flows are found in Kuwait, and rainwater only accumulates in small lakes for a matter of weeks before evaporating. As of 1994, Kuwait had two major aquifers: the Kuwait group and the Damman group, for which groundwater inflow was estimated at 20 million $\mathrm{m}^{3}$ annually. ${ }^{590}$ Groundwater quality and quantities have been decreasing rapidly, and the World Resources Institute reported in 2003 that Kuwait has no surface water production, no groundwater, and no internal renewable water

\footnotetext{
587 "Nation Decides Against Future Use of Nuclear Power", Worldwide Report, 11 August 1986. Nuclear Threat Initiative Abstract, http://www.nti.org/db/nuclear/1986/n8600649.htm

${ }^{588}$ Weitz, Richard. "Gulf Cooperation Council Moves Forward with Nuclear Energy Plans", WMD Insights, April 2007. Accessed 7 May 2007.

http://www.wmdinsights.com/I14/I14_ME3_GCCMovesForward.htm

${ }^{589}$ Qusti, Raid. "Preliminary Report on GCC Nuclear Energy by Year-End," Arab News, 22 May 2007.

Accessed 4 June 2007.

http://www.arabnews.com/?page $=1 \&$ section $=0 \&$ article $=96485 \& \mathrm{~d}=22 \& \mathrm{~m}=5 \& \mathrm{y}=2007$

${ }^{590}$ Food and Agriculture Organization of the United Nations. Kuwait. Land and Water Development

Division. Accessed 5 June 2007. http://www.fao.org/ag/AGL/aglw/aquastat/countries/kuwait/index.stm
} 
resources. ${ }^{591}$ Though demand for water is the lowest among Gulf States, water must still be provided for the Kuwaiti per capita consumption rate of $116.2 \mathrm{~m}^{3}$ per year. $^{592}$

Water desalination, then, is a primary source of freshwater in Kuwait. The first desalination plant was established in 1953 with a total capacity of $4,545 \mathrm{~m}^{3}$ per day. ${ }^{593}$ Today, water production from desalination is over $1,600,000 \mathrm{~m}^{3}$ per day (see Table 1, below). Almost all of wastewater produced is treated (as of 1994), and just less than half has been reused. Interestingly, when the Iraqis invaded Kuwait, they looted most movable industrial equipment of value. This required the Kuwaitis to replace much of their technology, but it resulted in the latest equipment now being used in industry - and particularly for desalination.

Nuclear desalination is an attractive prospect for Kuwait because water desalination is an energy-intensive process (See Appendix Q). No feasibility studies or plans for nuclear desalination are under way, but this could be an application of a future Kuwaiti nuclear program.

\begin{tabular}{|c|c|}
\hline Process & Water production capacity $\left(\mathrm{m}^{3} /\right.$ day $)$ \\
\hline Multistage flash & $1,468,750$ \\
\hline Multi effect & 11,672 \\
\hline $\begin{array}{c}\text { Vapor } \\
\text { compression }\end{array}$ & 150 \\
\hline Reverse Osmosis & 166,472 \\
\hline Electrodialysis & 5,093 \\
\hline Total & $1,652,137$ \\
\hline
\end{tabular}

Table 1. Current water desalination production capacity, by type of process. Note that all water desalination in Kuwait currently uses thermal generation capabilities; nuclear power is a more efficient method, once installed. ${ }^{594}$

Kuwait seems to pose little proliferation threat, particularly because its economy and national security is interrelated with those of the United States. The United States is currently Kuwait's largest supplier of goods and services, and the U.S. Department of State has stated that, "Kuwait was a vital coalition partner" in the Iraq war. During the lead up to the second Gulf War, the country reserved $60 \%$ of its land mass as a base for American military troops and provides other assistance, including making a pledge of $\$ 1.5$ billion dollars for reconstruction. ${ }^{595}$

\footnotetext{
591 "Water Resources and Freshwater Ecosystems-- Kuwait”, World Resources Institute, 2003. Accessed 5 June 2007. http://earthtrends.wri.org/pdf_library/country_profiles/wat_cou_414.pdf

592 Al-Mutaz, Ibrahim S. "Potential of nuclear desalination in the Arabian Gulf countries," International Journal of Nuclear Desalination, Vol. 135, 2001. Accessed 11 June 2007. http://www.desline.com/articoli/4048.pdf

${ }^{593}$ Food and Agriculture Organization of the United Nations. Kuwait. Land and Water Development Division. Accessed 5 June 2007. http://www.fao.org/ag/AGL/aglw/aquastat/countries/kuwait/index.stm ${ }^{594}$ Al-Sabeeh, Dr. Abdel Kahled. "Desalination Country Focus: Kuwait." Watermark: The Newsletter of the Middle East Desalination Research Center, Issue 12, April 2001. Accessed 5 June 2007. http://www.ewatermark.org/watermark12/article1.htm

${ }^{595}$ Bureau of Near Eastern Affairs. "Background Note: Kuwait," U.S. Department of State, May 2007. Accessed 5 June 2007. http://www.state.gov/r/pa/ei/bgn/35876.htm
} 
The country's national security is closely tied to that of the members of the United Nation's Security Council as well. Kuwait has concluded defense arrangements with the United Kingdom, Russia, and France; China is the only permanent member of the UN Security Council that has not signed a military cooperation agreement with the country. ${ }^{596}$

Kuwait has sought missile contracts from the British, Russians, Chinese, Americans, and French. Kuwait's national security is also interrelated with that of its neighbors, and has sustained defense affiliations with other key Arab members of the Gulf War coalition, such as Egypt and Syria. Proximity to Iran has sparked Kuwaiti concern regarding negative consequences of a technical, environmental, or political Iranian nuclear program failure. In May 2007, NATO experts met with Kuwaiti officials to assess nuclear emergency preparedness in Kuwait. The country is reported to fear consequences of nuclear accidents in Iran or confrontation between Iran and the West over Iran's disputed nuclear program. ${ }^{597}$ Iran recently offered to share its nuclear expertise with the GCC states, reportedly for peaceful nuclear energy purposes. ${ }^{598}$

Kuwait has not demonstrated any interest in nuclear weapons and has sought only peaceful applications of nuclear technology, primarily in the fields of nuclear electricity generation and nuclear desalination. Regarding the collaborative GCC program, many of the details of the nuclear initiative have yet to be addressed, such as a source of fuel, location, and financing. At an early March summit in 2007, the Council issued a joint statement affirming the governments' desire for a WMD-free zone in the Middle East, calling for a peaceful solution regarding Iran's nuclear program, demanding Israel's accession to the Treaty on the Nonproliferation of Nuclear Weapons (NPT), and declaring their continued interest and pursuit of a nuclear research and development program for peaceful energy purposes. (Weitz 2007)

\section{ECONOMIC}

\section{Electricity}

Kuwait produces about 40.37 billion $\mathrm{kWh}$ of electricity annually, of which $100 \%$ is produced from thermal generation plants. The country consumes 37.54 billion $\mathrm{kWh}$ per year, at a consumption rate per capita even higher than the United States. Kuwait does not import or export electricity. (CIA Factbook 2007)

Kuwait's enormous per capita energy consumption is largely due to heavy use of air conditioning, water desalination for primary water resources, and highly subsidized electricity prices. Kuwait has five power stations with a total electrical generation capacity of about $9.4 \mathrm{GW}$. Increases in rate of demand for electricity is projected to

\footnotetext{
${ }^{596}$ Finnegan, Philip. “Kuwait to Continue Diversification in Arms Buys," Defense News, 28 November 1994. Nuclear Threat Initiative Abstract, Accessed 5 June 2007. http://www.nti.org/db/missile/1994/m9404922.htm

597 "NATO experts assess Kuwait's nuclear emergency contingency plans," Associated Press in International Herald Tribune, 6 May 2007. Accessed 5 June 2007. http://www.iht.com/articles/ap/2007/05/06/africa/ME-GEN-Kuwait-NATO-Nuclear.php ${ }^{598}$ Bibbo', Barbara. "Iran offers to share nuclear expertise with GCC states", Gulf News, 13 April 2007. Accessed 4 June 2007. http://archive.gulfnews.com/articles/07/04/13/10117924.html
} 
remain at a strong rate of 7 to $9 \%$ annually for the coming years, and Kuwait will need to institute new generating capacity to meet this need. ${ }^{599}$

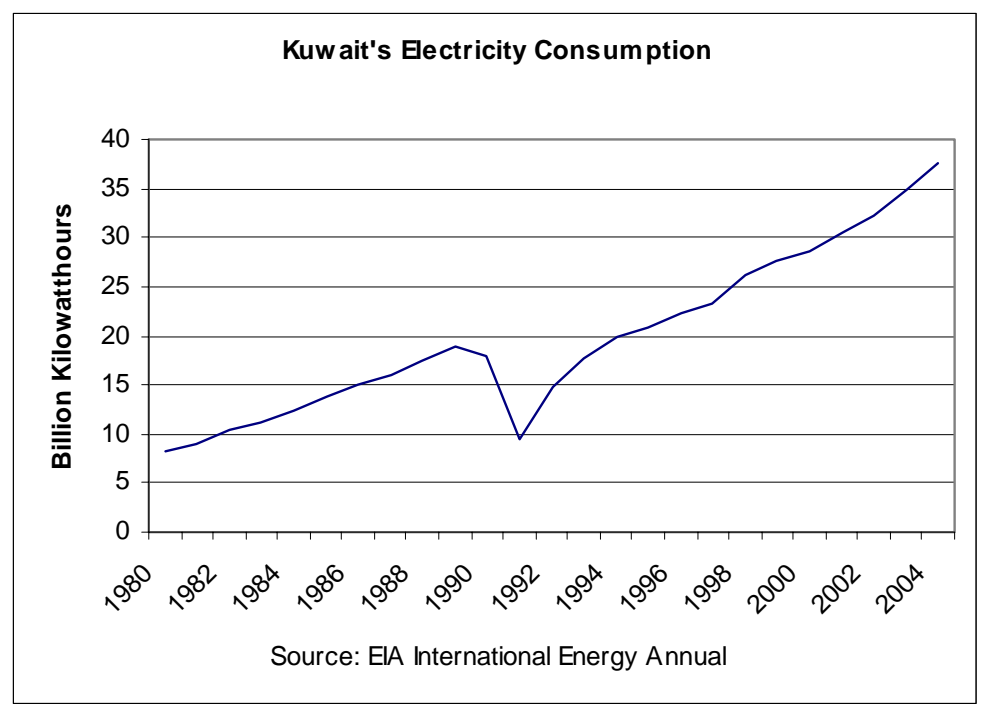

Figure 1. Steady increase in Kuwait's electricity consumption, excepting the effect of the Gulf War. 600

The Kuwait Institute for Scientific Research has reported that half of electricity consumption is residential, and, "The Ministry of Electricity and Water estimates that the electricity subsidy is nearly 13 times the price residential electricity users pay for their electricity consumption." ${ }^{\circ 01}$ Therefore, the government has recommended more efficient use of electricity to residents, and could further increase consumer efficiency by reducing subsidies.

In order to meet consumer demands for electricity, Kuwait also plans to connect its electrical grid with the grids of other GCC countries in the near future, which would increase spare capacity during peak hours and provide the option of exporting electricity when domestic demand decreases. Kuwait has also discussed linking networks with Iran. $^{602}$

\section{Oil}

As one of OPEC's major oil producers, Kuwait's current production capacity is about 2.5 million bbl per day. The country consumes a small fraction of the oil produced, only $335,000 \mathrm{bbl}$ per day, which allows almost two million bbl per day of the oil to be exported. Kuwait does not import oil.

\footnotetext{
${ }^{599}$ Energy Information Administration. "Kuwait: Electricity”, U.S. Department of Energy. Accessed 5 June 2007. http://www.eia.doe.gov/emeu/cabs/Kuwait/Electricity.html ${ }^{600}$ Ibid.

${ }^{601}$ Al-Qudsi, Sulayman S., and Abdul Majeed Al-Shatti. "Restructuring Existing Electricity Tariff: A Welfare Assessment," Economics Department, Kuwait Institute for Scientific Research

602 "Water and Electricity", Abu Dhabi Water and Electricity Authority, 2007. Accessed 4 June 2007. http://www.adwea.com/en/weSystem/
} 
Kuwait's oil industry is managed by the Kuwait Petroleum Company (KPC), ${ }^{603}$ a parent company that includes the Kuwait Oil Company (KOC), which produces oil and gas; Kuwait National Petroleum Company, which manages refining and domestic sales; Petrochemical Industries Company, which produces ammonia, urea, ethylene, propylene, and styrene; Kuwait Foreign Petroleum Exploration Company, which is responsible for exploration and upstream production outside Kuwait (in several developing countries and Australia); Kuwait Oil Tanker Company.; Kuwait Gulf Oil Company, responsible for exploration and production in the Kuwait portions of the offshore and onshore Divided Zone; and Kuwait Petroleum International, which manages refining and retail operations outside Kuwait in Europe and East Asia. (U.S. Department of State 2007)

Kuwait's vast oil reserves amount to about 96.5 billion bbl. This includes reserves found in a 6,200 square-mile "Divided Zone" which Kuwait shares with its southern neighbor Saudi Arabia. The countries proportion equally the Zone's petroleum resources, onshore and offshore. Most of Kuwait's domestic reserves are located in the Greater Burgan area, which is considered the world's second largest oil field. This field has a production capacity of around 1.6 million bbl per day, and has been producing oil since 1938. ${ }^{604}$ Several new discoveries of light oil in the past few years have significantly bolstered Kuwait's oil reserves, but since most of Kuwait's major oil producing fields are over sixty years old, production capacity has been projected to decrease as resources become exhausted. In 2005, KOC projected fifteen percent decreases in production over the next few decades; ${ }^{605}$ other discoveries of oil therefore have much more importance. In order to expand production, KOC intends to expand exploratory drilling, and center focus on developing heavy oil from its northern fields. (EIA 2006)

Kuwait's three domestic refineries have a combined capacity of roughly 936,000 bbl per day. Kuwait reportedly is planning to spend over $\$ 8$ billion through 2010 on upgrading its refining sector. ${ }^{606}$

\footnotetext{
${ }^{603}$ Kuwait Petroleum Company, http://www.kpc.com.kw/index2.htm

${ }^{604}$ Energy Information Administration. "Kuwait: Oil”, U.S. Department of Energy, November 2006. Accessed 5 June 2007. http://www.eia.doe.gov/emeu/cabs/Kuwait/Oil.html

${ }^{605}$ Kuwait Oil Company, http://www.kockw.com/KOCHomeSite

${ }^{606}$ Energy Information Administration. "Kuwait: Oil", U.S. Department of Energy, November 2006. Accessed 5 June 2007. http://www.eia.doe.gov/emeu/cabs/Kuwait/Oil.html
} 


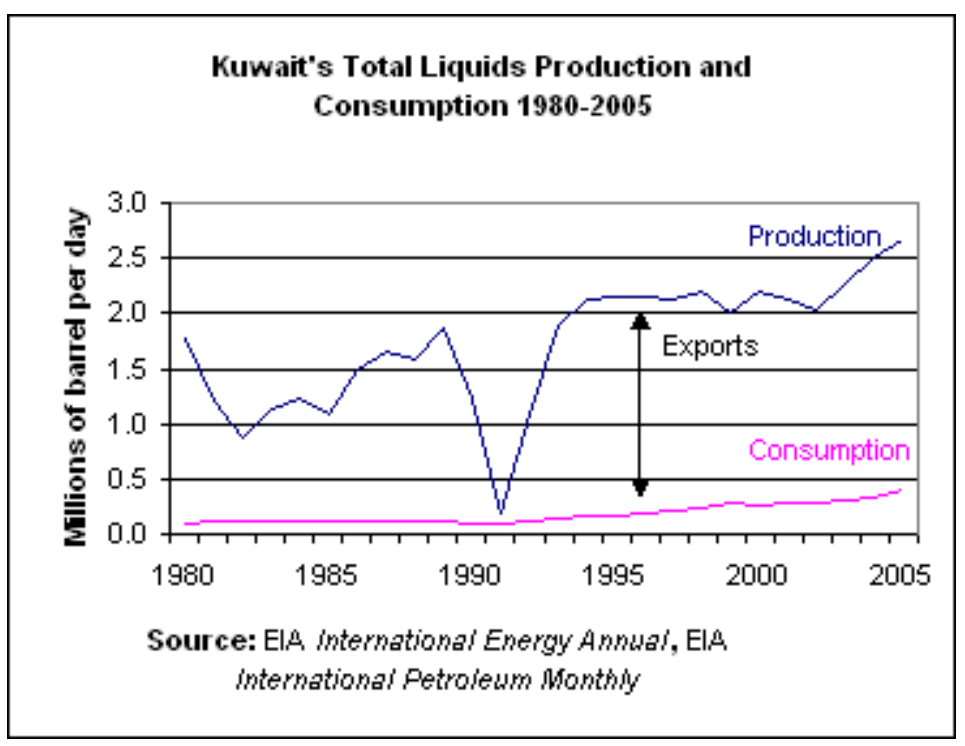

Figure 2. Kuwait's liquid oil production and consumption. Note the effect on production of the Iraqi invasion in 1990, and the rapid resumption of production to previous levels by 1993. ${ }^{607}$

In a plan called "Project Kuwait", the country has established a goal of production capacity expansion from the current 2.5 million bbl per day to 4 million bbl per day in 2010 and to 5 million bbl per day by 2020. Implementation of the plan has been delayed, however, because it stipulates investment by foreign oil companies in upstream oil supplies, and Kuwait's domestic policy has been slow to agree to such a foreign role in control over oil resources. (EIA 2006)

Natural Gas

Most of Kuwait's annual 9.7 billion cubic meters in natural gas production is "associated gas" produced in conjunction with oil. Currently Kuwait consumes all the natural gas it produces, and does not import or export natural gas. Because of the economic benefits of increasing oil available for export, Kuwait hopes to significantly increase its use of natural gas in electricity generation, water desalination, and petrochemicals. To augment its 1.57 trillion cubic meters of natural gas reserves, Kuwait plans to reduce flaring of associated gas and to increase exploratory drilling. Kuwait has also initiated future plans for importing natural gas from Iraq, Iran, and Qatar. Prior to the First Gulf War, Kuwait imported natural gas from Iraq. Plans for restarting the pipeline were initiated in a Memorandum of Understanding in December 2004, but are pending an improved security situation in Iraq. In July 2000, Kuwait signed a Memorandum of Understanding with Qatar for the future import of natural gas through a pipeline from Qatar to Kuwait. The pipeline, however, passes through Saudi territorial waters, and Saudi Arabia has expressed opposition to the plan and has not granted approval. In March 2005, Kuwait signed a Memorandum of Understanding with Iran in order to import gas for power generation and water desalination purposes. A dispute over

${ }^{607}$ Energy Information Administration. "Kuwait: Oil”, U.S. Department of Energy, November 2006. Accessed 5 June 2007. http://www.eia.doe.gov/emeu/cabs/Kuwait/Oil.html 
territorial waters, specifically concerning the Dorra offshore natural gas field, has put these plans on hold for the present. ${ }^{608}$ (EIA 2006, CIA Factbook 2007)

\section{INTERNATIONAL TREATY COMMITMENTS AND IAEA COOPERATION}

IAEA Membership and International Treaty Commitments

Kuwait became a member of the IAEA in 1976, and established a comprehensive Safeguards Agreement which took effect in 2002. Kuwait signed and ratified an Additional Protocol to its IAEA Safeguards Agreement, which took effect in 2003. It has signed and ratified several other multilateral conventions regulating nuclear applications. In that regard, the country ratified the Treaty on the Non-Proliferation of Nuclear Weapons (NPT) in 1989. Kuwait signed the Limited (Partial) Test Ban Treaty in 1965, and signed the Comprehensive Test Ban Treaty in 1996 and ratified it in 2003. Kuwait has qualified and has been approved for the Small Quantities Protocol with the IAEA as well. $609,610,611,612,613$

Kuwait has begun to institute the necessary legal framework for a nuclear program by acceding to agreements and conventions on the physical protection of nuclear material, the privileges and immunities of the IAEA, and the Convention on Nuclear Safety. Its signature and ratification of an IAEA safeguards agreement and an Additional Protocol is significant, as it is one of few Middle Eastern countries to have established an Additional Protocol. However, it has not yet signed important agreements regarding issues such as civil liability for nuclear damage and spent fuel and radioactive waste management. For a full list of Kuwait's commitments to multilateral conventions and safeguards agreements with the IAEA, see Appendix M.

\section{IAEA Technical Cooperation Projects}

Kuwait participates in nine active Technical Cooperation (TC) projects and has completed two TC projects with the IAEA. Its TC program is modest in size relative to the number of projects underway with other Middle East countries. One of Kuwait's first projects concerned Nuclear Power and was initiated in 1976 in order to explore "advice

\footnotetext{
${ }^{608}$ Energy Information Administration. “Kuwait: Natural Gas”, U.S. Department of Energy, November 2006. Accessed 5 June 2007. http://www.eia.doe.gov/emeu/cabs/Kuwait/NaturalGas.html

${ }^{609}$ International Atomic Energy Agency. "Strengthened Safeguards System: Status of Additional Protocols," 22 March 2007. Accessed 5 June 2007.

http://www.iaea.org/OurWork/SV/Safeguards/sg_protocol.html

${ }^{610}$ Federation of American Scientists. Signatories and Parties to the Treaty on the Non-Proliferation of Nuclear Weapons. 3 December 1998. Accessed 5 June 2007. http://www.fas.org/nuke/control/npt/text/npt3.htm

${ }^{611}$ Bureau of Verification, Compliance, and Implementation, U.S. Department of State. "Treaty Banning Nuclear Weapon Tests in the Atmosphere, in Outer Space, and Under Water." Accessed 5 June 2007. http://www.state.gov/t/ac/trt/4797.htm\#signatory

${ }^{612}$ CTBTO Preparatory Commission. "Status of Signature and Ratification.” 2007. Accessed 5 June 2007. http://www.ctbto.org

${ }^{613}$ International Atomic Energy Agency. "Safeguards Current Status", 16 May 2007. Accessed 5 June 2007. http://www.iaea.org/OurWork/SV/Safeguards/sir_table.pdf
} 
on nuclear power programming". Other more recent projects have focused on human resource development and nuclear technology support, nuclear techniques for pollution control, dosimetry, groundwater hydrology, and naturally occurring radioactive materials from the oil industry. Most recently instituted is a TC project on the "Assessment of Atmospheric Transport of Radionuclides" in the category of emergency preparedness and response, which implicitly regards the consequences to Kuwait of an Iranian nuclear explosion or accident. ${ }^{614}$

\section{REGIONAL PROJECT POSSIBILITIES}

Kuwait is already in the process of collaboration with other GCC countries to research possibilities of a future joint nuclear program to supply nuclear power and nuclear desalination capabilities. Installation of operative facilities is not expected for at least twelve years, though. During this time, Kuwait could focus on building domestic education resources or strengthening its research infrastructure in collaboration with other Arab nations, and GCC countries in particular. Kuwait will also need to develop much stronger regulatory framework, and could partner with Egypt in establishing stronger regulations. Greater involvement in IAEA TC projects could also help target areas such as human resource development, legislative infrastructure, and feasibility research before Kuwait launches a more sophisticated nuclear program.

\footnotetext{
${ }^{614}$ International Atomic Energy Agency, "IAEA - TC Projects by Country: Kuwait." Accessed 5 June 2007. http:/www-tc.iaea.org/tcweb/tcprogramme/projectsbycountry/default.asp
} 


\section{OMAN}

Overview

Oman is the easternmost of Arab countries. Positioned at a strategic location along the Strait of Hormuz, through which about one-fifth of the world's oil passes. Oman is small in area but rich in energy and mineral resources. Oman is about the size of Kansas, ranking $83^{\text {rd }}$ of countries in the world by area. Though only about $0.26 \%$ of the land is useful for agriculture, farming and fishing are the traditional way of life in Oman. Oman has very limited natural fresh water resources, for which the country has compensated by building several desalination plants. The country has an energy consumption rate of about $4,159 \mathrm{kWh}$ per capita, slightly greater than the world average of $2,962 \mathrm{~kW}$ but much less than the U.S. rate of $12,454 \mathrm{kWh}$ consumed per capita. ${ }^{615}$

Oman has a population of about 3.2 million, but some 660,000 expatriates live in the country. Its population is $134^{\text {th }}$ in the world. A high population growth rate of $3.2 \%$ is largely due to a high fertility rate. A majority (75\%) of Oman's population is Ibhadi Muslim. Ibadhism is a form of Islam distinct from Shi'aism and Sunnism, and is known for its "moderate conservatism". Oman is the only country in the Islamic world with a majority Ibadhi population; minorities of Sunni Muslim, Shi'a Muslim, and Hindu religions are also found in Oman.

In 1970 Sultan Qaboos bin Said al-Said overthrew the restrictive regime of his father, and in his rule since, has initiated extensive modernization programs particularly in medicine and in education. Oman's first university opened in 1986, and it remains the country's only public university, though other private universities and post-secondary institutions, such as trade schools, have since been established. ${ }^{616}$

Oman's economy is heavily dependent on oil revenues, which account for about $75 \%$ of the country's export earnings and $40 \%$ of its GDP. ${ }^{617}$ High oil prices have helped Oman's trade surplus and expanded foreign reserves in recent years, and the Ministry of National Economy reports 2006 GDP growth rates of $15.6 \%{ }^{618}$ Nominal GDP per capita in Oman, which is $\$ 14,100$, is slightly higher than the world average of $\$ 10,000$; Oman ranks $70^{\text {th }}$ in the world by GDP per capita, but lower than many other oil-rich nations. Oman continues to work towards attracting foreign capital investments, privatization, market liberalization. To decrease the unemployment rate of about $15 \%$, the government aims to replace foreign workers with local workers. Oman is a small and highly competitive market for the United States, but prospects for the U.S. market in Oman are expanding with the implementation of a Free Trade Agreement signed in January 2006 and with continuing U.S. investments in oil production.

In its foreign relations, Oman has close ties with its Arab neighbors in the Gulf Cooperation Council, has traditionally supported Middle East peace initiatives, and

\footnotetext{
${ }^{615}$ Central Intelligence Agency. "Oman,” The World Factbook. Last updated 31 May 2007. Accessed 6 June 2007. https://www.cia.gov/library/publications/the-world-factbook/geos/mu.html

${ }^{616}$ Bureau of Near Eastern Affairs. "Background Note: Oman," U.S. Department of State, May 2007. Accessed 7 June 2007. http://www.state.gov/r/pa/ei/bgn/35834.htm

${ }^{617}$ Energy Information Administration. “Oman: Background”, U.S. Department of Energy, April 2007. Accessed 7 June 2007. http://www.eia.doe.gov/emeu/cabs/Oman/Background.html 618 "2006 Review of the Economy of the Sultanate of Oman", Ministry of National Economy, Sultanate of Oman. Accessed 8 June 2007. http://www.moneoman.gov.om/Eco_Money17.asp
} 
maintains good relations with Iran. Never a British colony, the country sustains longstanding close ties with the United Kingdom. Oman's borders with all its neighbors have been demarcated, including a 2002 demarcation of the Oman-UAE border that was ratified in 2003 and a border dispute with Yemen resolved in October 1992. Nonetheless, Oman's military expenditures as a percent of GDP are the highest in the world, at $11.4 \%$. (Energy Information Administration 2007, CIA Factbook 2007, U.S. Department of State 2007)

Oman has minimal technical nuclear capability. The country is not a member of the IAEA, and has instituted very little of the legal framework necessary for a safe and sustainable nuclear program. Oman has expressed interest as part of the Gulf Cooperation Council (GCC) to begin studying nuclear program possibilities, and due to limits on recoverable natural gas and oil resources, would benefit from any future GCC nuclear power generation capabilities. Oman also has very limited water resources, and nuclear desalination is another attractive possibility. However, Oman will require significant international collaboration with its Arab neighbors and with nations advanced in peaceful applications of nuclear technology in order to begin a domestic nuclear program.

\section{NUCLEAR INFRASTRUCTURE/INTENTIONS}

\section{Infrastructure}

\section{Knowledge management}

Oman's overall literacy rate of $81.4 \%$ is fairly high for the Middle East, yet there is a disparity between men and women in literacy rates: $86.8 \%$ and $73.5 \%$, respectively. ${ }^{619}$ Education is free to Omani citizens through secondary school, but it is not required. Sultan Qaboos University (SQU) is the premier public university in Oman; several other Colleges of Technology and a few Institutes of Health have been established as well. These colleges offer basic engineering, physics, and chemistry degrees, among others, but none have listed any nuclear-related programs or coursework. The College of Medicine at Sultan Qaboos University, though, has a Nuclear Medicine Unit. SQU also offers degree programs in physics with a minor in medical physics.

In a basic literature search, all published nuclear research found was conducted on nuclear medicine applications, and the research was conducted at Sultan Qaboos University. The research focused on disease identification and treatment. No other nuclear research was found to have been recently published by Omani scientists.

$\underline{\text { Uranium Resources }}$

Oman does not have any identified uranium deposits. ${ }^{620,621}$

\footnotetext{
${ }^{619}$ Central Intelligence Agency. "Oman,” The World Factbook. Last updated 31 May 2007. Accessed 6 June 2007. https://www.cia.gov/library/publications/the-world-factbook/geos/mu.html

${ }^{620}$ Joint Report by the OECD Nuclear Energy Agency and the International Atomic Energy Agency. Uranium 2005:Resources, Production, and Demand, Paris: OECD Publishing, 2005. p. 215-9.

${ }^{621}$ Integrated Nuclear Fuel Cycle Information Systems, World Distribution of Uranium Deposits Database. International Atomic Energy Agency. 2003. Accessed 5 June 2007. http://www-nfcis.iaea.org/
} 


\section{Nuclear Reactors and Fuel Facilities}

Oman does not have any known nuclear reactors or conversion, enrichment, or fuel facilities. ${ }^{622,623}$

Regulation

Oman does not appear to have any regulatory agencies for any nuclear-related activities.

\section{Intentions}

As a member of the Gulf Cooperation Council (GCC), Oman has recently shown interest in developing a joint plan for nuclear energy generation in the near future. Oman participated in commissioning of the feasibility study in December 2006 on employing nuclear technology for peaceful purposes in accord with international regulations and standards. The countries plan to use nuclear power only for peaceful purposes, such as meeting increasing demands for electricity, water desalination, and agriculture. In May 2007, an IAEA delegation began meeting with representatives of the six GCC member countries in order to discuss the implementation of IAEA regulations for the development of nuclear power. A preliminary report is scheduled to be submitted to GCC leaders at the next summit, which will take place in December 2007 in Oman. ${ }^{624}$ Oman's expanding electricity demand, limited water resources, and increasing demand for water may spark interest in the nuclear applications.

Oman currently generates all the electricity it consumes via thermal generation plants. Maximum power demand in the northern part of Oman is expected to grow from $2,544 \mathrm{MW}$ in 2006 to $4,634 \mathrm{MW}$ by 2013 , at an annual average increase of around $9 \%$ or $300 \mathrm{MW}$ per year. Increases of about $14 \%$ per year are projected for other areas of the country. New power generation facilities are under construction, but more plants will need to be built in order to satisfy this demand. ${ }^{625}$

Oman's water resources are quite limited. Average annual rainfall has been estimated at only $55 \mathrm{~mm}$ (compare to about $750 \mathrm{~mm}$ for the state of Kansas, which has approximately the same area). ${ }^{626}$ As of 1997, internal renewable water resources were evaluated at 985 million $\mathrm{m}^{3}$ per year. Most of this water is groundwater, which is increasing in salinity due to overdrawing. There are few surface water resources, occurring mostly in wadis for a few hours following a storm. About half of wastewater is treated and reused. Flood control dams have been built to retain water that flows through

\footnotetext{
${ }^{622}$ Research Reactor Database. "Nuclear Research Reactors in the World." International Atomic Energy Agency, 1999. Accessed 5 June 2007. http://www.iaea.org/worldatom/rrdb/

${ }^{623}$ NFCIS, "List of Nuclear Fuel Cycle Facilities." International Atomic Energy Association, 2003. Last updated 31 January 2000. Accessed 5 June 2007. http://www-nfcis.iaea.org/Default.asp

${ }^{624}$ Qusti, Raid. "Preliminary Report on GCC Nuclear Energy by Year-End," Arab News, 22 May 2007. Accessed 4 June 2007.

$\mathrm{http}: / / \mathrm{www}$.arabnews.com/?page=1\&section=0\&article $=96485 \& \mathrm{~d}=22 \& \mathrm{~m}=5 \& \mathrm{y}=2007$

${ }^{625}$ Prabhu, Conrad. "Oman: Major Power, desalination plant on anvil," Oman Daily Observer, 30 April 2007. Accessed 7 June 2007.

http://www.middleeastelectricity.com/upl_images/news/Oman\%20Major\%20power\%20desalination\%20pl ant $\% 20$ on\%20anvil.pdf

${ }^{626}$ Food and Agriculture Organization of the United Nations. Oman. Land and Water Development

Division. Accessed 8 June 2007. http://www.fao.org/ag/AGL/aglw/aquastat/countries/kuwait/index.stm
} 
wadis after a storm, and currently the Wadi Dhiqa Dam project is being built to increase water resources by 35 million $\mathrm{m}^{3}$ each year. Other dams are under construction. ${ }^{627}$

Ahmed Al-Busaidi of the Ministry of Housing, Electricity, and Water reports a substantial increase in water demands in the past ten to fifteen years in conjunction with a deterioration of groundwater and decrease in rainfall. Per capita annual demand has reached $821.6 \mathrm{~m}^{3}$, the highest among Gulf States. ${ }^{628}$ A significant portion of Oman's water needs are met through desalination plants, with production capacity in 2003 reaching over $250,000 \mathrm{~m}^{3}$ per day, of which $95 \%$ is produced by the multi-stage flash (MSF) distillation process using steam and the rest from Reverse Osmosis (RO) membrane technology driven by electric pumps. ${ }^{629}$

Overall demand for desalinated water is expected to increase from 86 million $\mathrm{m}^{3}$ in 2006 to 221 million $\mathrm{m}^{3}$ for 2013 . Up to $201,000 \mathrm{~m}^{3}$ per day of additional desalination capacity will be required from 2009 to 2013 . As with power generation facilities, new water desalination facilities are under construction, but more desalination plants must be built in the future in order to satisfy increasing demand. ${ }^{630}$

The Middle East Desalination Research Center (MEDRC) is an international nonprofit organization dedicated to research and education on desalination with an emphasis on regional requirements for the Middle East. The Center was established in 1996 in Oman's capital of Muscat. MEDRC states its mission as follows:

"To conduct, facilitate, promote, co-ordinate and support basic and applied research in water Desalination technology and supporting fields. To raise the standard of living in the Middle East and elsewhere by cost reduction and quality improvement in the technical processes of water desalination."631

The objectives of the Center include conducting basic and applied research on water desalination methods development and improvement, training programs, and relationship building with other states to improve the process of water desalination in the Middle East and elsewhere. Representatives of MEDRC's member countries come from all over the world. Oman, Israel, Jordan, the Palestinian National Authority, the United States, Japan, South Korea, the Netherlands, and the European Commission are all involved in the work of MEDRC.

\footnotetext{
627 "Statistics", Water Resources Sector. Ministry of Regional Municipalities, Environment, and Water Resources. http://www.mrmewr.gov.om/english/water/statistics.htm

${ }^{628}$ Al-Mutaz, Ibrahim S. "Potential of nuclear desalination in the Arabian Gulf countries," International Journal of Nuclear Desalination, Vol. 135, 2001. Accessed 11 June 2007. http://www.desline.com/articoli/4048.pdf

${ }^{629}$ Al-Busaidi, Ahmed. "Desalination in Oman \& the Fundamentals of the Reverse Osmosis Design", Ministry of Housing, Electricity and Water. Accessed 7 June 2007. http://www.rcuwm.org.ir/events/seminars/1/files/AHMEDALBUSAIDI.PDF

${ }^{630}$ Prabhu, Conrad. "Oman: Major Power, desalination plant on anvil," Oman Daily Observer, 30 April 2007. Accessed 7 June 2007.

http://www.middleeastelectricity.com/upl_images/news/Oman\%20Major\%20power\%20desalination\%20pl ant $\% 20$ on $\% 20$ anvil.pdf

631 "Institute Overview", About the Center, Middle East Desalination Research Center. http://www.medrc.org/
} 
Nuclear desalination may be an attractive prospect for Oman because water desalination is an energy-intensive process (See Appendix Q). No feasibility studies or plans for nuclear desalination are under way, but this could be an application of a future Omani nuclear program.

Oman seems to pose very little proliferation threat. Because the country lacks the technological capability of producing a nuclear weapon, or even nuclear materials, any proliferation concern would stem from its ability to serve as a transfer point for technology or materials. But Oman has taken steps to minimize this risk and to implement export controls for nuclear materials. In November 2005, Oman signed an agreement with the U.S. National Nuclear Security Administration (NNSA) to help detect and deter illicit trafficking of nuclear and other radioactive material. This agreement initiates the implementation of the NNSA's Megaports Initiative in Oman. Oman is one of four Middle Eastern countries to have joined the Initiative; the others are UAE (Dubai), Israel, and Egypt. ${ }^{632}$

Oman has not demonstrated any interest in nuclear weapons. Official Omani policy states that the government "has no reason not to believe Iran's assurances that its program has purely civilian purposes", and reiterates the country's desire to maintain peace. ${ }^{633}$ Oman's interests in nuclear electricity generation and nuclear desalination are still nascent and appear to involve only collaboration with GCC interests.

\section{ECONOMIC}

\section{Electricity}

Oman produces 14.33 billion kWh annually and consumes 13.33 billion kWh; the country does not import or export electricity. ${ }^{634}$ All of Oman's installed electric generating capacity comes from thermal sources. The country aims to privatize all stateowned companies in the power sector by $2009 .{ }^{635}$

By law, the Oman Power \& Water Procurement Company (PWP) is the sole purchaser of the entire output of power and water. In light of solidly increasing electricity demand, projected at about $9 \%$ annually for at least the next five years, PWP forecasts a need for increased future power generation capacity in the country. The company is responsible for holding competitive bids for the procurement of new power plants, in conjunction with desalination facilities where appropriate. ${ }^{636}$

\footnotetext{
${ }^{632}$ Wilkes, Brian. "U.S. and Oman to Cooperate on Detecting Illicit Shipments of Nuclear Material," National Nuclear Security Administration, 19 November 2005. NA-05-29. Accessed 8 June 2007. http://www.nnsa.doe.gov/docs/newsreleases/2005/PR_2005-11-19_NA-05-29.htm

633 “Oman's Regional and Global Priorities”, Ministry of Foreign Affairs, Sultanate of Oman, 2006. Accessed 7 June 2007. http://www.mofa.gov.om/ministry/foriegnpolicy/omanposition

${ }^{634}$ Central Intelligence Agency. "Oman," The World Factbook. Last updated 31 May 2007. Accessed 6 June 2007. https://www.cia.gov/library/publications/the-world-factbook/geos/mu.html

${ }^{635}$ Energy Information Administration. "Oman: Electricity”, U.S. Department of Energy, April 2007. Accessed 7 June 2007. http://www.eia.doe.gov/emeu/cabs/Oman/Oil.html

${ }^{636}$ Prabhu, Conrad. “Oman: Major Power, desalination plant on anvil,” Oman Daily Observer, 30 April 2007. Accessed 7 June 2007. http://www.middleeastelectricity.com/upl_images/news/Oman\%20Major\%20power\%20desalination\%20pl ant $\% 200 n \% 20$ anvil.pdf
} 
Oman has not demonstrated significant investment in alternative energy resources at present. The Omani company Oman Solar Systems Co. LLC has installed 12 projects of solar power, mostly for electricity generation in the interior, with a total peak power capacity of $238.9 \mathrm{~kW} .{ }^{637}$ Two other solar energy companies have been established in Oman, but there are no large-scale projects for alternative energy resources.

Oman's Electricity Generation and Consumption, 1994-2004

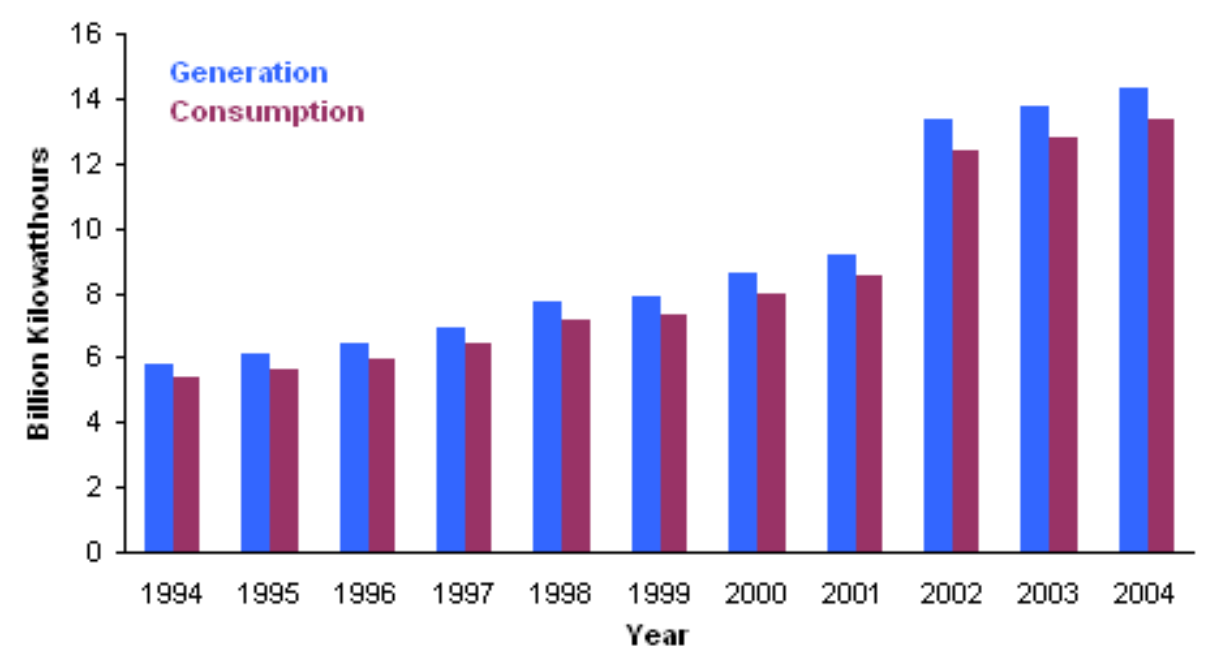

Source: ElA International Energy Annual 2004

Figure 1. Increases in Electricity Generation and Consumption in Oman ${ }^{638}$

Oil

Oil was first discovered in the interior near Fahud in the western desert in 1964, but Oman does not have the same immense oil resources as some of its neighbors. The country's geography makes exploration and production expensive and technically challenging. Oman's oil fields were discovered much later than those of its neighbors, and the fields are generally smaller, more widely scattered, less productive, and pose higher production costs than in other Persian Gulf countries. However, improvements in technology have enhanced recovery rates. Omani oil production has fluctuated significantly over the past twenty years, and as of 2006 was about 740,000 bbl per day, though this rate has been decreasing over the past six years. The country consumes $60,000 \mathrm{bbl}$ per day, and current total proven reserves are about 4.7 billion bbl. (Energy Information Administration 2007, CIA Factbook 2007, U.S. Department of State 2007)

Oman is not a member of OPEC. Most of Oman's crude oil exports, which are about 721,000 bbl per day, are sold to Asian countries, with China, India, Japan, South Korea, and Thailand as the largest importers. Oman does not import oil.

Petroleum Development Oman (PDO) is the leading oil producer in Oman, but several foreign companies are also involved in upstream activities. Oman's government

${ }_{638}^{637}$ Oman Solar Systems Co. LLC, http://www.omansolar.com/ 
manages its investments in the downstream sector through the state-owned Oman Oil Company (OOC).

Oman's Oil Production and Consumption, 1998-2008*

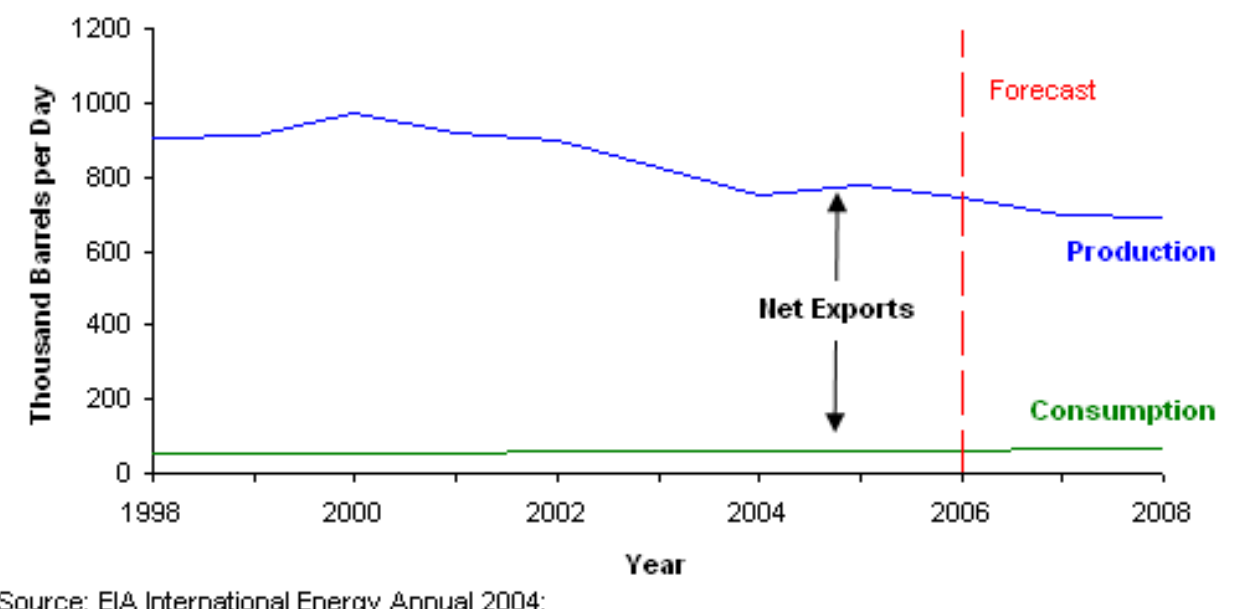

Short-Term Energy Outlook (March 2007)

*2006 is estimate

Figure 2. Trends in Oman's oil production and consumption rates, 1998-2008. ${ }^{639}$

Oman's Minister of Oil and Gas announced in April 2006 that the country is planning to invest $\$ 10$ billion in upstream oil and natural gas projects during the next five years. Much of this effort will focus on enhanced oil recovery (EOR) initiatives to improve recovery rates at several of the country's oil fields. EOR projects are expected to increase production rates, but they are costly and require large amounts of water and natural gas.

\section{Natural Gas}

Current natural gas production in Oman is about 17.2 billion cubic meters annually. Production increases in recent years have been used for enhanced oil recovery projects, but the rate of increase in production has tapered off during the last few years. Proven reserves of natural gas amount to 829.1 billion cubic meters; additional natural gas reserves have not been located as quickly as the government had hoped. Future increases in natural gas production depend upon the development of "tight" natural gas reserves, which are geologically complex structures considered much more difficult to access than conventional natural gas reserves. These reserves could significantly expand Oman's natural gas resources, but are technically challenging and expensive to develop.

Oman currently consumes about 6.77 billion cubic meters of natural gas and exports 10.43 billion cubic meters annually; it does not import natural gas. Domestically the resource is currently being reinvested in oil extraction projects through EOR initiatives. Some industry sources have speculated that, given the country's long-term

${ }^{639}$ Energy Information Administration. “Oman: Oil”, U.S. Department of Energy, April 2007. Accessed 8 June 2007. http://www.eia.doe.gov/emeu/cabs/Oman/Oil.html 
liquefied natural gas (LNG) export obligations, natural gas supplies may be overcommitted in Oman.

Oman is a participating country in the Dolphin Project, which aims to connect the natural gas networks of Qatar, the United Arab Emirates (UAE), and Oman. Oman currently exports about $175 \mathrm{MMcf}$ per day of piped natural gas to the UAE via two pipelines, but through the Dolphin Project, will ultimately import natural gas from Qatar. ${ }^{640}$ (EIA 2007, CIA Factbook 2007)

\section{INTERNATIONAL TREATY COMMITMENTS AND IAEA COOPERATION}

IAEA Membership and International Treaty Commitments

Though Oman is not a member state of the IAEA, it signed a safeguards Agreement which entered into force in September 2006. Oman has not established an Additional Protocol to its Safeguards Agreement, but has qualified and been approved for the Small Quantities Protocol. Oman acceded to the Treaty on the Non-Proliferation of Nuclear Weapons (NPT) in 1997. The country does not appear to have signed the Limited (Partial) Test Ban Treaty, but it signed the Comprehensive Test Ban Treaty in 1999 and ratified it in $2003 .{ }^{641,642,643,644,645,646}$

Oman has signed almost none of the international agreements which constitute a legal framework for a nuclear program. Oman has signed the Convention on the Physical Protection of Nuclear Material, but has not signed or ratified conventions concerning civil liability for nuclear damage, spent fuel and radioactive waste management, the privileges and immunities of the IAEA, or the Convention on Nuclear Safety. For a full list of Oman's status on commitments to multilateral conventions and safeguards agreements with the IAEA, see Appendix N.

\footnotetext{
${ }^{640}$ Energy Information Administration. “Oman: Natural Gas”, U.S. Department of Energy, April 2007. Accessed 7 June 2007. http://www.eia.doe.gov/emeu/cabs/Oman/NaturalGas.html

641 "List of IAEA Member States", International Atomic Energy Agency, March 2007. Accessed 6 June 2007. http://www.iaea.org/About/Policy/MemberStates/

${ }^{642}$ International Atomic Energy Agency. "Strengthened Safeguards System: Status of Additional Protocols," 22 March 2007. Accessed 5 June 2007.

http://www.iaea.org/OurWork/SV/Safeguards/sg_protocol.html

${ }^{643}$ Federation of American Scientists. Signatories and Parties to the Treaty on the Non-Proliferation of Nuclear Weapons. 3 December 1998. Accessed 5 June 2007. http://www.fas.org/nuke/control/npt/text/npt3.htm

${ }^{644}$ Bureau of Verification, Compliance, and Implementation, U.S. Department of State. "Treaty Banning Nuclear Weapon Tests in the Atmosphere, in Outer Space, and Under Water." Accessed 5 June 2007. http://www.state.gov/t/ac/trt/4797.htm\#signatory

${ }^{645}$ CTBTO Preparatory Commission. "Status of Signature and Ratification." 2007. Accessed 5 June 2007. http://www.ctbto.org

${ }^{646}$ International Atomic Energy Agency. "Safeguards Current Status", 16 May 2007. Accessed 5 June 2007. http://www.iaea.org/OurWork/SV/Safeguards/sir_table.pdf
} 


\section{IAEA Technical Cooperation Projects}

Oman cannot be involved in Technical Cooperation projects with the IAEA because the country is not a member. ${ }^{647}$

\section{REGIONAL PROJECT POSSIBILITIES}

Oman will require significant international collaboration if the country decides to seriously pursue developing nuclear technology for electricity generation or water desalination purposes. Egypt's much more advanced nuclear program could provide insight and guidance to Omani officials and scientists; even more limited programs such as that in Morocco could aid Oman in its early stages of nuclear energy development. Oman currently intends to work with other GCC nations in any pursuit of a nuclear program, and this will provide increased funds for research and development, though the GCC would benefit from external assistance in developing institutional, educational, and legal framework for nuclear activities.

\footnotetext{
${ }^{647}$ International Atomic Energy Agency, "IAEA - TC Projects by Country." Accessed 6 June 2007. http://www-tc.iaea.org/tcweb/tcprogramme/projectsbycountry/default.asp
} 


\section{QATAR}

Overview

Qatar is a small peninsula in the Persian Gulf with an area slightly smaller than Connecticut. It became independent from Britain in 1971, and in 2001 resolved its borders after longstanding disputes with its neighbors Bahrain and Saudi Arabia. The country has about $2 \%$ arable land and very limited natural fresh water resources; this has resulted in increasing dependence on large desalination facilities. However, revenues from the export of the country's large oil and natural gas resources enable Qatar to have one of the highest per capita incomes in the world. Oil and gas account for more than $60 \%$ of GDP, roughly $85 \%$ of export earnings, and $70 \%$ of government revenues. The country boasts a GDP per capita rivaling that of the European Union, an unemployment rate of only 3.2\%, and economic growth rates of $15 \%$ over the past five years. Qatar is forecast to have the highest per capita income in the world within the next few years. ${ }^{648}$ The country also has a very high energy consumption rate of about $12,709 \mathrm{kWh}$ per capita, compared to the world average of $2,962 \mathrm{~kW}$ and slightly greater than the U.S. rate of $12,454 \mathrm{kWh}$ consumed per capita. ${ }^{649}$

Qatar's population of about 907,000 people includes many immigrants from Pakistan, India and Iran, as well as about 6,000 U.S. citizens. The U.S. Department of State reports that foreigners with temporary residence constitute about three-fourths of the total population. Qataris are mainly Sunni Wahabi Muslims, and Islam is the official religion.

Qatar was an early member of OPEC and a founding member of the Gulf Cooperation Council (GCC), and it maintains close ties with the United States. Qatar's military expenditures as a percent of GDP are among the highest in the world at $10 \%$, yet Qatar keeps only a "modest military force" of about 12,000 men. Qatar has supported critical U.S. military operations in the U.S.-Iraq war. (U.S. Department of State 2007, CIA Factbook 2007)

Qatar has a strong education system, but little to no nuclear technology base. Its primary research oversight organization has developed introductory radiation and export controls for nuclear materials, which are a fundamental predecessor for a further advanced program. Qatar intends to develop a nuclear program for peaceful applications in collaboration with the GCC. Though Qatar has no lack of energy resources, nuclear energy would allow the country to increase exports of natural gas and would also establish a more cost-efficient and environmentally friendly method of water desalination. Qatar will need first to further establish its legal and technical nuclear infrastructure in order to participate in a nuclear program.

\footnotetext{
${ }^{648}$ Bureau of Near Eastern Affairs. "Background Note: Qatar,” U.S. Department of State, October 2006. Accessed 11 June 2007. http://www.state.gov/r/pa/ei/bgn/5437.htm

${ }^{649}$ Central Intelligence Agency. "Qatar," The World Factbook. Last updated 31 May 2007. Accessed 8 June 2007. https://www.cia.gov/library/publications/the-world-factbook/geos/qa.html
} 


\title{
1. NUCLEAR INFRASTRUCTURE/INTENTIONS
}

\author{
Infrastructure
}

Knowledge management

Qatar boasts a literacy rate of $89 \%$, and as well as a rate that is approximately equal among men and women. Such high literacy is partly due to the fact that education is free and compulsory for all Arab residents ages 6 to 16. Higher education is encouraged as well: hundreds of Qatari students study in the United States each year, and Qatar's newly inaugurated "Education City" houses branches of leading American universities such as Cornell University, Texas A\&M, and Carnegie Mellon.

The domestic education system offers some training on basic nuclear physics, but very little nuclear research is conducted in Qatar. Qatar University was established in 1973 and is the main Qatari university. It offers a Bachelor's of Science program with a Physics Major/Chemistry Minor and concentration in Radiation and Nuclear Physics. This includes one required upper-level class in Nuclear Physics, as well as elective courses in Radiation Physics and second-level Nuclear Physics. The research facilities for the program include Gamma Cell, X-ray fluorescence (Tifa), Positron annihilation, Laser, and Electronics. ${ }^{650}$

The Supreme Council for the Environment and Natural Reserves (SCENR) is the main oversight institution of scientific research in Qatar, and it includes a Nuclear Applications Department. SCENR is mainly responsible for radiation regulation, and does not list any nuclear research or training on their website. ${ }^{651}$

Some research has been conducted on environmental radiation. In 1995, Qatar measured levels of radioactivity in various locations within the country, in order to monitor fallout from the Chernobyl accident. The Qatar peninsula is located about 4500 $\mathrm{km}$ from Chernobyl. ${ }^{652}$

\section{Uranium Resources}

$\overline{\text { Qatar does not have any identified uranium deposits. }}{ }^{653,654}$

Nuclear Reactors and Fuel Facilities

Qatar does not have any known nuclear reactors or conversion, enrichment, or fuel facilities. ${ }^{655,656}$

\footnotetext{
${ }^{650}$ Program in Physics, College of Arts \& Sciences, University of Qatar. http://www.qu.edu.qa/doc/cas/phys_chemistry.doc

${ }^{651}$ Supreme Council for the Environment and Natural Reserves, http://www.qatarenv.org/english.htm

${ }^{652}$ Al-Tahni, A. A., S. Abdul-Majid, and K. Mohammed. "Levels of Radioactivity in Qatar," Transactions of the American Nuclear Society, Winter meeting of the American Nuclear Society, 31 December 1995.

${ }^{653}$ Joint Report by the OECD Nuclear Energy Agency and the International Atomic Energy Agency. Uranium 2005:Resources, Production, and Demand, Paris: OECD Publishing, 2005. p. 215-9.

${ }^{654}$ Integrated Nuclear Fuel Cycle Information Systems, World Distribution of Uranium Deposits Database. International Atomic Energy Agency. 2003. Accessed 5 June 2007. http://www-nfcis.iaea.org/

655 Research Reactor Database. "Nuclear Research Reactors in the World." International Atomic Energy Agency, 1999. Accessed 5 June 2007. http://www.iaea.org/worldatom/rrdb/

${ }^{656}$ NFCIS, "List of Nuclear Fuel Cycle Facilities." International Atomic Energy Association, 2003. Last updated 31 January 2000. Accessed 5 June 2007. http://www-nfcis.iaea.org/Default.asp
} 


\section{$\underline{\text { Regulation }}$}

SCENR was established as the primary radiation regulatory agency by Decree Number 31 of 2002, which states, "The Council shall have the authority to supervise the regulation and control of the use of radioactive material and sources and protection against the associated hazards." The Council formulates legislation on radiation sources, establishes national limits and standards for radiation levels, licenses radiation-related activities and practices, supervises waste management, inspects facilities where sources are used, monitors radiation in the environment, and validates personnel training on radiation, nuclear safety, and radiation protection. The law also states that the Ministry of Public Health is responsible for issuing licenses for medical physics purposes. Furthermore, the law establishes a Radiation Protection Committee within SCENR, which is comprised of representatives from Qatar's government ministries, scientific organizations, and energy-related private companies. The Committee develops and implements Qatar's general radiation protection plan. It examines cases of radiation effects or environmental contamination and develops radiation emergency plans, and is the main working body of SCENR for radiation activities and regulation. ${ }^{6}$

SCENR has also instituted some export controls over chemical materials, a licensing system, and a chemical database including information about chemical materials and importing companies. Other activities of SCENR include seventeen training scholarships in the fields of medical and scientific radioactivity protection; hiring IAEA experts to help develop radioactivity protection law; creating a detailed registry for institutions and companies licensed to work with radioactive materials, and the materials they use; and issuing an information booklet on radioactivity. ${ }^{658}$

\section{Intentions}

As a member of the Gulf Cooperation Council (GCC), Qatar has recently expressed the desire to develop a joint plan for nuclear energy generation in the near future. It participated in the commissioning of a feasibility study in December 2006 on employing nuclear technology for peaceful purposes in accord with international regulations and standards. Qatar's expanding population, significant technological growth, burgeoning electricity demand, and limited water resources may contribute to its interest in peaceful applications of nuclear technology.

Qatar is experiencing increased electricity needs of a growing population, especially as industry expands. Since 1998, electricity consumption has increased at an average rate of over $10 \%$ per year. ${ }^{659}$ All of Qatar's electricity is generated by thermal plants using natural gas, an abundant resource, but one which Qatar may prefer to export or supplement with alternative energy resources for increased revenues and decreased carbon dioxide emissions.

\footnotetext{
${ }^{657}$ Decree Number 31 of 2002 on Radiation Protection, Emir Hamad bin Khalifa Al Thani, 29 September 2002. Accessed 11 June 2007. http://www.qatarenv.org/english.htm

658 “Activities", Supreme Council for the Environment and Natural Reserves, http://www.qatarenv.org/english.htm

659 “Qatar: Evolution of Electricity Generation by Fuel from 1971 to 2004,” International Energy Agency. http://www.iea.org/Textbase/country/index.asp
} 
Qatar's water resources, though, are extremely limited. The World Resources Institute estimates that as of 1977-2001, Qatar had no surface water produced internally and no groundwater recharge. ${ }^{660}$ Natural water resources stem mainly from rainfall, which only amounts to $75 \mathrm{~mm}$ per year. ${ }^{661}$ The rate of water consumption is projected to continually increase with a population growth rate of $2.4 \%$; current demand for fresh water currently reaches about $318.9 \mathrm{~m}^{3}$ per year. ${ }^{662}$ To meet domestic demands for potable water, Qatar established its first desalination plant in Doha in 1953. In 1995, Qatar had two plants with a capacity of 98.6 million $\mathrm{m}^{3}$ per year. ${ }^{63}$ Other plants are currently under contract to be built. Qatar's Ministry of Foreign Affairs explains the plants' capacity and demand in the following terms: "The total design output capacity of water from all sources is 112.5 million gallons per day, while the actual daily requirement for water is about 90 million gallons." 664 The country currently produces sufficient water to adequately meet its residents' needs.

Nuclear desalination is an attractive prospect for Qatar because water desalination is an energy-intensive process (See Appendix Q). No feasibility studies or plans for nuclear desalination are under way.

Qatar has shown some recent interest in developing nuclear energy in addition to its feasibility research in collaboration with the GCC. The country began talks with South Korea in February 2006 on nuclear energy cooperation. A Qatari delegation visited South Korean nuclear facilities and met with representatives of South Korea's Science and Technology Ministry in order to discuss nuclear applications in agriculture, medicine and biotechnology. ${ }^{665}$

Historically close in economic terms with Iran, Qatar was the only country to vote "no" on the July 2006 Resolution 1646 of the UN Security Council, which mandated that Iran suspend all enrichment-related and reprocessing activities. ${ }^{666}$ The Lawyers' Committee on Nuclear Policy reports on Qatar's objections to UN Resolution 1747, which toughened sanctions against Iran and added an arms embargo: "Qatar and Indonesia submitted a number of amendments to the resolution, intended to clarify certain points and to give it more balance." 667 A representative of Qatar expressed reservations about the text of the resolution, noting that Qatar "[did] not view sanctions as an appropriate means of pressure." The representative cautioned against the selective

\footnotetext{
${ }^{660}$ World Resources Institute. "Water Resources and Freshwater Ecosystems: Country Profiles", 2006. Accessed 7 May 2007. http://earthtrends.wri.org/text/water-resources/country-profiles.html ${ }^{661}$ Al-Mutaz, Ibrahim S. "Potential of nuclear desalination in the Arabian Gulf countries," International Journal of Nuclear Desalination, Vol. 135, 2001. Accessed 11 June 2007. http://www.desline.com/articoli/4048.pdf

${ }^{662}$ Central Intelligence Agency. "Qatar," The World Factbook. Last updated 31 May 2007. Accessed 8 June 2007. https://www.cia.gov/library/publications/the-world-factbook/geos/qa.html

663 "Qatar", Land and Water Development Division, Food and Agriculture Organization of the United Nations, 1997. Accessed 11 June 2007. http://www.fao.org/ag/agl/aglw/aquastat/countries/qatar/index.stm ${ }^{664}$ Electricity and Water Sector, Ministry of Foreign Affairs, http://english.mofa.gov.qa/details.cfm?id=106 665 "Oil-rich Qatar going nuclear," World Tribune, 13 February 2006. Accessed 11 June 2007. http://www.worldtribune.com/worldtribune/06/front2453780.0965277776.html ${ }^{666}$ Fitzpatrick, Mark , 'Can Iran's Nuclear Capability Be KeptLatent?', Survival: the IISS Quarterly, Vol. 49 No. 1, Spring 2007. Accessed 8 June 2007. http://dx.doi.org/10.1080/00396330701254503

${ }^{667}$ Spies, Michael. "The Security Council and Iran: Further Escalation and Isolation, Commentary on resolution 1747 (2007) on Iran,” 3 April 2007. Accessed 11 June 2007. http://www.lcnp.org/disarmament/iran/unsc1747commentary.pdf
} 
enforcement of the Nonproliferation Treaty, which some Arab states feel turns a blind eye to Israel's nuclear program while imposing sanctions on Iran. Qatar's Embassy explains their foreign policy as follows: "Qatar favors a policy of constructive engagement with [Iran and Iraq]. By contrast, the United States favors isolating them through its policy of 'dual containment.",668 Qatar's security and defense ties with the United States balances its foreign policy; U.S. military bases are currently positioned in the country, Qatar has expressed willingness to host U.S. Central Command, and the United States is helping Qatar expand a large air base that could potentially be used to host U.S. aircraft. For these reasons, as well as Qatar's limited nuclear technical capability, Qatar seems to pose little proliferation threat.

Qatar has not demonstrated any interest in nuclear weapons and has sought only peaceful applications of nuclear technology. The country's primary nuclear interests, nuclear electricity generation and nuclear desalination, are still preliminary at best.

\section{ECONOMIC}

\section{Electricity}

Qatar produces 12.4 billion $\mathrm{kWh}$ of electricity, entirely from natural gas powered thermal generation plants, and residents consume 11.53 billion $\mathrm{kWh}$. Qatar does not import or export electricity. ${ }^{669}$

Rising demand has initiated the expansion of generation capacity, and levels of maximum generating capacity increased by $44 \%$ from 2000 to 2004 . The government expects electricity demand to continue significant growth rates in the near future.

As a result of electricity demand exceeding generation capability in recent years, the government restructured the country's power sector by increasing privatization and foreign investment. The state-owned Qatar General Electricity \& Water Corporation (Kahramaa) retains control of electricity purchase, transmission, and distribution. Qatari nationals currently receive free electricity and water supplies.

The most recent new power project came online in late 2006 and is the Ras Laffan B power and water generation facility. It will be expanded by 2008 for a total capacity of $1025 \mathrm{MW}$ power generating capacity. A contract was awarded in October 2006 to a Japanese company for the construction of another power station, which will have a power capacity of $2000 \mathrm{MW}$. It is expected to be completed in 2010. ${ }^{670}$ (EIA 2007, CIA Factbook 2007)

\section{Oil}

The Second World War initially delayed oil production in Qatar, and oil exports did not begin until 1949. ${ }^{671}$ Today, oil production amounts to $790,500 \mathrm{bbl}$ per day.

\footnotetext{
668 "Foreign Policy", Embassy of the State of Qatar in Washington, D.C., http://www.qatarembassy.net/foreign_policy.asp

${ }^{669}$ Central Intelligence Agency. "Qatar," The World Factbook. Last updated 31 May 2007. Accessed 8 June 2007. https://www.cia.gov/library/publications/the-world-factbook/geos/qa.html

${ }^{670}$ Energy Information Administration. "Qatar: Electricity”, U.S. Department of Energy, May 2007. Accessed 12 June 2007. http://www.eia.doe.gov/emeu/cabs/Qatar/Electricity.html

${ }^{671}$ Bureau of Near Eastern Affairs. "Background Note: Qatar," U.S. Department of State, October 2006. Accessed 11 June 2007. http://www.state.gov/r/pa/ei/bgn/5437.htm
} 
Qatar's crude oil production and reserves are the lowest among OPEC member countries, yet less than $15 \%$ of domestic energy consumption comes from oil, and most of Qatar's oil production is exported. Asian markets are the primary consumers of Qatar's oil exports, with Japan as the single largest purchaser of Qatari oil. Domestic consumption is about $80,000 \mathrm{bbl}$ per day, and proven reserves consist of 15.2 billion bbl of oil. ${ }^{672}$

Qatar Petroleum (QP) controls all aspects of Qatar's oil sector; it is a state-owned corporation, but often enlists foreign company involvement and investment. The chairman of QP is also the head of the Ministry of Energy and Industry as well as the Deputy Prime Minister of Qatar.

QP has instituted enhanced oil recovery projects in order to boost production capacity and extend the life of its oil fields. International oil companies are conducting exploration and production work in offshore areas, but there have been no major oil discoveries in Qatar for the last decade. Production capacity is expected to expand, though, through the enhancement of existing production facilities. Qatar has one refining plant with a 200,000 bbl per day capacity at Umm Said, and is building another refinery with a capacity of 146,000 bbl per day, which is expected to be operation in mid-2008; the country is also considering building a third refinery in the near future. (U.S. Department of State 2006, EIA 2007, CIA Factbook 2007)

\section{Natural Gas}

Qatar's natural reserves of 25.77 trillion cubic meters make up 15\% of total world reserves, and are the third largest reserves in the world, after Russia and Iran. Most of Qatar's natural gas is located in the North Field, a geological extension of Iran's South Pars field. Qatar produces 39.17 billion cubic meters of natural gas annually, and plans to significantly expand natural gas production to about 8.7 Tcf by 2012 , or nearly six times greater than production levels in 2005. This expansion will come primarily from expanded output capacity on the Northern Field. The country also plans to nearly triple its liquefied natural gas (LNG) production capacity by 2012.

Qatar began exporting LNG in 1997 in small amounts. Today, Qatar is the leading world exporter of LNG with 24.06 billion cubic meters exported annually, and has further plans for exports as part of the Dolphin Project. The Dolphin Project aims to establish the first cross-border oil pipelines between Oman, the United Arab Emirates (UAE), and Qatar; it is expected to begin operation in June 2007. Natural gas is exported through the pipeline from Qatar to the UAE and to Oman, at a volume expected to reach 2 Bcf per day by the end of $2007 .{ }^{673}$

QP also plays a dominant role in Qatar's natural gas sector. Qatar consumes 15.11 billion cubic meters of natural gas annually, and does not import natural gas. (EIA 2007, CIA Factbook 2007)

\footnotetext{
${ }^{672}$ Energy Information Administration. “Qatar: Oil”, U.S. Department of Energy, May 2007. Accessed 12 June 2007. http://www.eia.doe.gov/emeu/cabs/Qatar/Oil.html

${ }^{673}$ Energy Information Administration. “Qatar: Natural Gas”, U.S. Department of Energy, May 2007. Accessed 12 June 2007. http://www.eia.doe.gov/emeu/cabs/Qatar/NaturalGas.html
} 


\title{
3. INTERNATIONAL TREATY COMMITMENTS AND IAEA COOPERATION
}

\author{
IAEA Membership and International Treaty Commitments
}

Qatar became a member of the IAEA in 1976, but it has not been significantly involved in the IAEA. Qatar did accede to the Treaty on the Non-Proliferation of Nuclear Weapons (NPT) in 1989. Qatar has not established a safeguards agreement or an Additional Protocol. The country does not appear to have signed the Limited (Partial) Test Ban Treaty, but it signed the Comprehensive Test Ban Treaty in 1996 and ratified it in $1997 .{ }^{674,675,676,677,678,679}$

Though Qatar has established some international agreements in the past few years which have helped to develop its legal framework for nuclear technology, there are several crucial agreements and conventions to which Qatar has not yet acceded. These include the agreement on the privileges and immunities of the IAEA, civil liability for nuclear damage, the Convention on Nuclear Safety, and the agreement on spent fuel and waste management. For a full list of Qatar's status on multilateral conventions and safeguards agreements with the IAEA, see Appendix O.

\section{IAEA Technical Cooperation Projects}

All of Qatar's Technical Cooperation (TC) projects with the IAEA have been instituted in the past two years, but Qatar now has seven projects in process. These include projects concerning human resources development and technology support, strengthening capabilities at the Central Environmental Laboratory of SCENR for radioactivity monitoring in food and environment, establishing a National Nuclear Analytical Laboratory, and creating an early warning system for radiation emergencies. One project not yet funded involves strengthening Qatar's capabilities in radiotherapy and nuclear medicine. All of these programs are organized under the auspices of the Supreme Council for the Environment and Natural Reserves (SCENR). ${ }^{680}$

\footnotetext{
674 "List of IAEA Member States", International Atomic Energy Agency, March 2007. Accessed 6 June 2007. http://www.iaea.org/About/Policy/MemberStates/

${ }^{675}$ International Atomic Energy Agency. "Strengthened Safeguards System: Status of Additional Protocols," 22 March 2007. Accessed 5 June 2007. http://www.iaea.org/OurWork/SV/Safeguards/sg_protocol.html

${ }^{676}$ Federation of American Scientists. Signatories and Parties to the Treaty on the Non-Proliferation of Nuclear Weapons. 3 December 1998. Accessed 5 June 2007. http://www.fas.org/nuke/control/npt/text/npt3.htm

${ }^{677}$ Bureau of Verification, Compliance, and Implementation, U.S. Department of State. "Treaty Banning Nuclear Weapon Tests in the Atmosphere, in Outer Space, and Under Water." Accessed 5 June 2007. http://www.state.gov/t/ac/trt/4797.htm\#signatory

${ }^{678}$ CTBTO Preparatory Commission. "Status of Signature and Ratification." 2007. Accessed 5 June 2007. http://www.ctbto.org

${ }^{679}$ International Atomic Energy Agency. "Safeguards Current Status", 16 May 2007. Accessed 5 June 2007. http://www.iaea.org/OurWork/SV/Safeguards/sir_table.pdf

${ }^{680}$ International Atomic Energy Agency, "IAEA - TC Projects by Country." Accessed 6 June 2007. http://www-tc.iaea.org/tcweb/tcprogramme/projectsbycountry/default.asp
} 


\section{REGIONAL PROJECT POSSIBILITIES}

Qatar is currently collaborating with other GCC nations in developing a feasibility study for a joint nuclear energy program. Due to its close relations with other GCC nations, these countries can pool financial and personnel resources for the development of such a program. However, the technical capability in other GCC nations, as in Qatar, is fairly limited In order to institute any nuclear program, Qatar would likely need to collaborate with other Arab nations such as Egypt in order to expand its basis in nuclear research and technology before further nuclear work. With increased controls and oversight, which is being developed by SCENR, Qatar's Education City could become a regional site for other GCC nations to develop preliminary nuclear research. A working nuclear power plant, however, is unlikely to be developed for the GCC for another decade or more. 


\section{YEMEN}

\section{Overview}

The Republic of Yemen was formed when North Yemen and South Yemen joined in 1990. The country is about twice the size of Wyoming, yet only about $3 \%$ of the land area is arable, and fresh water resources are very limited. Yemen is situated at a strategic location on Bab el Mandeb, which is the strait linking the Red Sea and the Gulf of Aden and one of world's most active shipping lanes. Yet Yemen is one of the poorest countries in the world. Its nominal GDP per capita of only $\$ 1,000$ ranks $211^{\text {th }}$ in the world, and is one-tenth of the world average GDP per capita. The unemployment rate soars at about $35 \%$, and over $45 \%$ of the population lives below the poverty line. Yemen's per capita energy consumption of $171 \mathrm{kWh}$ is miniscule compared to the world average of 2,962 $\mathrm{kW}$, and about $1 \%$ of the $12,454 \mathrm{kWh}$ per capita consumed by U.S. citizens. The country's economy is largely dependent upon oil, yet most of Yemen's 22 million people, including 78,582 Somalian refugees, are employed in agriculture and herding. The population is primarily Muslim with Sunni and Shi'a communities, as well as small numbers of Jews, Christians, and Hindus. Yemen is not a member of the Gulf Cooperation Council. The International Monetary Fund (IMF) has instituted programs for financial and monetary reforms, reducing budget deficit, cutting subsidies, and civil service reform; the World Bank has provided aid on projects concerning public sector governance, water, and education. Despite these restructuring plans and other economic aid programs, little government dedication, in addition to corruption and excessive spending, has resulted in ineffective measures for the changes needed. ${ }^{681}$ The U.S. Department of State has lauded Yemen as an important partner in the global war on terrorism, providing assistance in the military, diplomatic, and financial arenas. ${ }^{682}$ (U.S. Department of State 2007, CIA Factbook 2007)

Yemen has insufficient electricity generating capacity and fresh water resources for its population, and is looking to nuclear energy and nuclear desalination as a means of alleviating these shortfalls. The country has taken some steps towards instituting a nuclear program, including the development of a regulatory agency for export controls. However, Yemen still has very limited legal and technical nuclear infrastructure, and could not financially support extensive nuclear research, training, and development. Though Yemen's current President has expressed strong interest in developing nuclear energy, the country will need significant collaboration and aid in order to achieve its optimistic goals in this area.

\footnotetext{
${ }^{681}$ Central Intelligence Agency. "Yemen," The World Factbook. Last updated 14 June 2007. Accessed 12 June 2007. https://www.cia.gov/library/publications/the-world-factbook/geos/ym.html

${ }^{682}$ Bureau of Near Eastern Affairs. "Background Note: Yemen," U.S. Department of State, February 2007. Accessed 12 June 2007. http://www.state.gov/r/pa/ei/bgn/35836.htm
} 


\title{
1. NUCLEAR INFRASTRUCTURE/INTENTIONS
}

\author{
Infrastructure
}

Knowledge management

Yemen's literacy rate is fairly low, even compared to its regional neighbors, with an overall rate of about $50 \%$. Women's literacy rates are only about $30 \%{ }^{683}$

Yemen's institutions of higher education and research do not focus on nuclearrelated activities. Yemen has several universities, including Sana'a University, Queen Arwa University, Al-Ahgaff University, University of Aden, University of Science and Technology Sana'a, and Hodeidah University. Sana'a University has a Chemistry and Physics Department, and Hodeidah University and University of Aden have Physics Departments as well. Little research or training is conducted at these institutions on nuclear-related subjects. An indoor radon survey conducted in association with the Department of Physics of Hodeidah University was published in $2003 .{ }^{684}$ A brief literature search showed no other nuclear physics related research published by Yemeni educational institutions.

The Central Laboratories of the Yemen Mineral Resources and Geological Survey at the Ministry of Oil and Mineral Resources conduct some research on the chemical composition and radioactivity of environmental and geological samples. Applications of nuclear medicine are being carried out at the National Centre for Radiation Oncology at the Al-Ghamhouri Teaching Hospital in Sana'a. These nuclear-related projects, as well as some others, are through Technical Cooperation projects with the IAEA, and are described in further detail below.

Uranium Resources

Yemen does not have any identified uranium deposits. ${ }^{685,686}$

Nuclear Reactors and Fuel Facilities

Yemen does not have any known nuclear reactors or conversion, enrichment, or fuel facilities. ${ }^{687,688}$

$\underline{\text { Regulation }}$

The National Atomic Energy Commission (NATEC) was established in 1999 for the purpose of building a radiation protection infrastructure for peaceful applications of

\footnotetext{
${ }^{683}$ Central Intelligence Agency. "Yemen," The World Factbook. Last updated 31 May 2007. Accessed 12 June 2007. https://www.cia.gov/library/publications/the-world-factbook/geos/ym.html

${ }^{684}$ Khayrat A.H. et al. "Indoor radon survey in dwellings of some regions in Yemen", Radiation Measurements, Vol. 36 No. 1, June 2003.

${ }^{685}$ Joint Report by the OECD Nuclear Energy Agency and the International Atomic Energy Agency. Uranium 2005:Resources, Production, and Demand, Paris: OECD Publishing, 2005. p. 215-9.

${ }^{686}$ Integrated Nuclear Fuel Cycle Information Systems, World Distribution of Uranium Deposits Database. International Atomic Energy Agency. 2003. Accessed 5 June 2007. http://www-nfcis.iaea.org/

687 Research Reactor Database. "Nuclear Research Reactors in the World." International Atomic Energy Agency, 1999. Accessed 5 June 2007. http://www.iaea.org/worldatom/rrdb/

${ }^{688}$ NFCIS, "List of Nuclear Fuel Cycle Facilities." International Atomic Energy Association, 2003. Last updated 31 January 2000. Accessed 5 June 2007. http://www-nfcis.iaea.org/Default.asp
} 
nuclear energy, and has since developed a system for locating, licensing, and securing radioactive sources. The country aims to be a leader in the Middle East in the field of nuclear security. To this end, NATEC has developed a "National Nuclear Security Action Plan" in collaboration with the IAEA. In an effort to combat illicit trafficking of nuclear material, Yemen provided training for customs officers, border guards, coast guards, and policemen, and has plans to equip its seaports, airports, and land entry points with tools for radiation detection. In February 2004, an IAEA report stated that, "Yemen is to be commended for its dynamic and proactive approach to radioactive security matters."689 NATEC has expressed the option of establishing a Nuclear Regulatory Authority in the near future.

\section{Intentions}

Yemen's current President Ali Abdullah Saleh promoted the development of a nuclear energy program in his campaign for election. ${ }^{690}$ The President's Science and Technology Advisor, Dr. Moustafa Bahran, has continued to advocate nuclear energy, and announced in December 2006 that the country intended to begin working on producing nuclear energy in 2007. ${ }^{691}$ Nuclear energy would be applied to electricity generation and nuclear desalination purposes. Installed electricity generating capacity in Yemen in 2004 amounted to only about $1 \mathrm{GW}$, all of which is generated from conventional thermal power plants. The Public Electricity Corporation, which operates about $80 \%$ of the country's generating capacity in addition to the national power grid, states that approximately a minimal one-third of Yemen's population has access to electricity. ${ }^{692}$ High demand and low generating capacity result in rolling blackouts, which create intermittent electricity supply even in cities. In rural areas, only $13 \%$ of the population has access to the national grid. Furthermore, the demands on electricity generating and transmission capabilities are expected to only increase, as Yemen's population is projected to double in less than 25 years. ${ }^{693}$ To address these concerns, the Electricity and Water Ministry has declared its goal of increasing power generating capacity to $1.4 \mathrm{GW}$ by 2010 to meet significantly rising demand. In 1997, the government initiated a reform package to restructure the energy sector, including efforts to privatize some aspects of the country's power sector, but these plans have been delayed indefinitely. ${ }^{64}$ President Ali Abdullah Saleh has also invited the private sector to participate in the development of renewable energy resources in Yemen, especially solar power for rural areas. Significant development of electricity generation capabilities

\footnotetext{
${ }^{689}$ Bahran, Moustafa Y. "Upgrading Nuclear Safety and Security Infrastructure in Yemen,” National Atomic Energy Commission. Accessed 14 June 2007. http://wwwpub.iaea.org/MTCD/Meetings/PDFplus/2007/cn142/cn142Papers/41_MY_Bahran.doc

${ }^{690}$ Mahmoud, Shaima. "Nuclear energy in Yemen: A conceivable dream?" Yemen Times, Iss. 1017 Vol. 14, January 2007. http://yementimes.com/article.shtml? $\mathrm{i}=1017 \& \mathrm{p}=$ report\&a=3

${ }^{691}$ Al-Kibsi, Huda. "Yemen to have nuclear energy by 2007," Yemen Observer, 25 December 2006. Accessed 14 June 2007. http://www.yobserver.com/sports-health-and-lifestyle/10011458.html 692 "Electricity and Water", Sector Background Information, Ministry of Planning and International Cooperation. http://www.mpic-yemen.org/new1/strategies.asp? contantmain=6\&key=17\&stratigy=76

${ }^{693}$ Al-Kibsi, Huda. "Yemen to have nuclear energy by 2007," Yemen Observer, 25 December 2006. Accessed 14 June 2007. http://www.yobserver.com/sports-health-and-lifestyle/10011458.html ${ }^{694}$ Energy Information Administration. "Yemen: Electricity", U.S. Department of Energy, September 2006. Accessed 14 June 2007. http://www.eia.doe.gov/emeu/cabs/Yemen/Electricity.html
} 
and transmission networks will be crucial for the modernization and industrial and economic growth of the country.

In addition to a dearth of electricity generating capabilities, Yemen also has a substantial lack of fresh water resources. According to the World Resources Institute, Yemen has $206 \mathrm{~m}^{3}$ per capita of internal renewable water resources, mostly from surface water produced internally and some groundwater recharge. ${ }^{695}$ The Yemen Times reports that Yemen's National Water and Sanitation Authority supplies only 30\% of the urban population with fresh eater, and no more than about $30 \%$ of rural populations have access to safe drinking water. The country is considering desalination to provide for its water needs, but has focused discussion on desalination for coastal towns or highland towns with sustainable brackish groundwater reserves that can be desalinated economically as a supplementary fresh groundwater source. ${ }^{696}$ Nuclear desalination may be an attractive prospect for Yemen because water desalination is an energy-intensive process (See Appendix Q). An alternative electricity resource implemented for desalination purposes would help temper a water situation which the Ministry of Planning and International Cooperation calls an "acute shortage" that "threatens a water crisis." ${ }^{697}$ The Ministry has instituted some reforms for water consumption, but water resources are still expected to fall short of demand.

In light of the reality of these shortages of electricity and water, the President's advisor Bahran writes,

"Mainly due to the lack of energy resources in Yemen in one hand (diminishing oil production and limited gas reserve) and the existing severe power shortages in the country (less than one Giga Watt), Yemen has no choice but to consider Nuclear Power both for its major urban needs and for industrial development as well as the growing services sector, in particular tourism.... Yemen is going to upgrade its Safety and Security Infrastructure to be suitable for any further development in the Peaceful Application of Nuclear Energy, particularly Nuclear Power and Desalination., ${ }^{\text {, } 98}$

Bahran notes that Yemen's security infrastructure requires further strengthening prior to the institution of a nuclear energy program, and has expressed a desire to align with international norms and standards regarding any development of a nuclear program. He has also declared Yemen's desire to work with Canada and the United States in order to develop this nuclear energy capability. "We will generate electrical energy from nuclear energy in cooperation with the United States and Canada," said Bahran. "In the first stage, we will generate 20,000 mega watts." With the current condition of the electric

\footnotetext{
695 "Water Resources and Freshwater Ecosystems - Yemen”, World Resources Institute, 2003. Accessed 14 June 2007. http://earthtrends.wri.org/pdf_library/country_profiles/wat_cou_887.pdf

${ }^{696}$ Al-Ghabiri, Ismail and Amel Al-Ariqi. "Water expert: Desalination or displacement for Sana'a residents," Yemen Times, Iss. 958 Vol. 14, 26 June 2006. Accessed 14 June 2007. http://yementimes.com/article.shtml? $\mathrm{i}=958 \& \mathrm{p}=$ health \&a=1

697 "Electricity and Water", Sector Background Information, Ministry of Planning and International Cooperation. http://www.mpic-yemen.org/new1/strategies.asp?contantmain $=6 \& \mathrm{key}=17 \&$ stratigy $=76$

${ }^{698}$ Bahran, Moustafa Y. "Upgrading Nuclear Safety and Security Infrastructure in Yemen," National Atomic Energy Commission. Accessed 14 June 2007. http://wwwpub.iaea.org/MTCD/Meetings/PDFplus/2007/cn142/cn142Papers/41_MY_Bahran.doc
} 
transmission grid, it is unlikely that the transmission system could support the amount of power generated by a nuclear power facility once it came on line. These optimistic nuclear power goals are remarkable, particularly in light of the other challenges the country faces in unemployment, corruption, and slow development.

Yet Bahran has already accomplished results in bringing nuclear techniques to Yemen. The first Radiation Oncology Center and the first Nuclear Medicine Center in Yemen were established under Bahran's leadership, and he has participated in countless national, regional and international professional meetings related to nuclear safety and security and the peaceful application of atomic energy in addition to representing Yemen in many political events worldwide. It has been reported furthermore that Bahran has been one of the strongest advocates of the international nuclear nonproliferation regime. ${ }^{699}$

Yemen reportedly imported Scud missile components from North Korea in 2002, which resulted in U.S. economic sanctions on North Korea, ${ }^{700}$ but the Center for Nonproliferation Studies reports that Yemen has no evidence of a nuclear weapons program, a chemical weapons program, or a biological weapons program. ${ }^{701}$ Given the country's limited technical capability, Bahran's commitment to international guidelines, and the country's implementation of export controls for nuclear material, Yemen seems to pose little threat of proliferation.

\section{ECONOMIC}

\section{Electricity}

In 2004, Yemen produced 4.077 billion $\mathrm{kWh}$ and consumed 3.792 billion $\mathrm{kWh}$. Yemen does not import or export electricity. (CIA Factbook 2007)

Reports indicate that Yemen's generation and transmission capabilities are completely inadequate to serve the population, as rolling blackouts affect the country's major cities, about one-third of the population has access to electricity, and demand for electricity continues to increase at an annual rate of about 5\%. Furthermore, though all electricity is generated using thermal power plants, Yemen aims to reduce its domestic consumption of oil in order to maximize available resources for export. In order to achieve its energy goals, the government plans to construct generation facilities powered by natural gas, expand the power grid, and introduce renewable energy resources such as solar energy to remote areas. For instance, in March 2005, one private company signed a contract to build a $340 \mathrm{MW}$ gas-fired power plant in Yemen near the Marib natural gas field, which is scheduled to begin commercial operations in 2008. In the near future, a total generating capability of $1000 \mathrm{MW}$ is planned to be constructed at the site. Another $2,800 \mathrm{MW}$ in generating capacity is planned for a gas-fired power plant at Safar. Many

\footnotetext{
${ }^{699}$ Al-Kibsi, Huda. "Yemen to have nuclear energy by 2007," Yemen Observer, 25 December 2006. Accessed 14 June 2007. http://www.yobserver.com/sports-health-and-lifestyle/10011458.html

700 "North Korea: United States Detects Missile Shipment to Yemen," Global Security Newswire, Nuclear Threat Initiative, 2 December 2002. Accessed 14 June 2007.

http://www.nti.org/d newswire/issues/2002/12/2/8s.html

${ }^{701}$ Barletta, Michael and Erik Jorgensen. "Weapons of Mass Destruction Capabilities and Programs:Yemen," Center for Nonproliferation Studies, last updated April 2006. Accessed 14 June 2007. http://cns.miis.edu/research/wmdme/yemen.htm
} 
of these efforts to improve Yemen's electricity infrastructure have been funded by the World Bank, the International Development Foundation, and the Arab Fund for Economic and Social Development, and the Saudi Fund for Development. Independent investment and privatization have also been beneficial in improving the electricity generating capacity of the country, as several smaller-scale power plants have recently been built through private funding and construction. ${ }^{702}$ (EIA 2006)

\section{Oil}

Yemen is a small non-OPEC oil producer which produces about 387,500 bbl per day. Oil exports, which amount to $370,300 \mathrm{bbl}$ per day, comprise roughly $70 \%$ of government revenue. Oil production is expected to decline in 2007 due to dwindling reserves, which are now about 3.72 billion bbl, but revenue is expected to remain stable as long as oil prices remain high. Yemen's oil production has in fact been decreasing at the two largest fields for the past few years, but despite declining production, the country plans to boost output to $500,000 \mathrm{bbl}$ per day in the coming years. Yemen consumes only about $85,000 \mathrm{bbl}$ per day.

Though most other Middle East nations have nationalized oil companies, Yemen relies heavily on private foreign companies for its oil production. Among the larger companies are Nexen of Canada, which produces about 200,000 bbl per day, and Hunt Oil of the United States, which produces an estimated 50,000 bbl per day; and Total of France, which produces about 30,000 bbl per day.

The Yemeni government hopes to increase oil production and oil exports through the discovery of more reserves. Civil war led to the withdrawal of several major international oil companies and limited oil exploration activities in the 1990's, but exploration has accelerated since 1997 . Yemen currently has a crude refining capacity of about $130,000 \mathrm{bbl}$ per day from two aging refineries.

A long-term prospect for the petroleum industry in Yemen is a proposed liquefied natural gas project (Yemen LNG), which plans to process and export Yemen's proven associated and natural gas reserves. ${ }^{703}$ (EIA 2006, U.S. Department of State 2007, CIA Factbook 2007)

\section{Natural Gas}

Yemen has no natural gas production, consumption, imports, or exports, but the country has plans to develop an export-based natural gas industry. Since the mid-1990s, a primary interest of Yemeni natural gas development has been focused on the export of liquefied natural gas (LNG). After setbacks due to civil unrest and other causes, a plan has been implemented for three foreign private companies to develop LNG, and the first exports, which will be sent to the United States and South Korea, are expected by the end of 2008. Yemen competes with Oman and Iran for developing LNG, and competitive prices have slowed Yemeni production. Yemen is now considering developing natural

\footnotetext{
${ }^{702}$ Energy Information Administration. "Yemen: Electricity”, U.S. Department of Energy, September 2006. Accessed 14 June 2007. http://www.eia.doe.gov/emeu/cabs/Yemen/Electricity.html

${ }^{703}$ Energy Information Administration. "Yemen: Oil", U.S. Department of Energy, September 2006. Accessed 14 June 2007. http://www.eia.doe.gov/emeu/cabs/Yemen/Oil.html
} 
gas for domestic electricity generation, and has plans to build three power plants to be fueled with natural gas. Proved reserves of natural gas are reported to be 478.6 billion cubic meters. $^{704,705}$ (EIA 2007, CIA Factbook 2007)

\section{INTERNATIONAL TREATY COMMITMENTS AND IAEA COOPERATION}

\section{IAEA Membership and International Treaty Commitments}

Yemen became a member of the IAEA in 1994. Its Safeguards Agreement entered into force in September of the same year; the country qualifies and has been accepted for the Small Quantities Protocol. Yemen has not signed an Additional Protocol to its Safeguards Agreement.

Yemen Arab Republic signed the Treaty on the Non-Proliferation of Nuclear Weapons (NPT) in 1968 and ratified it in 1986. Yemen signed the Comprehensive Test Ban Treaty in September 1996 but has not yet ratified it. ${ }^{706,707,708,709,710}$

Yemen is not a signatory of the Chemical Weapons Convention or the Biological Toxins Weapons Convention. ${ }^{711}$

Yemen has entered into virtually none of the legal agreements required for developing the framework for a nuclear program. For a full list of Yemen's status on multilateral and safeguards agreements with the IAEA, see Appendix P.

\section{IAEA Technical Cooperation Projects}

Though Yemen became a member of the IAEA only recently, it has already instituted 21 Technical Cooperation (TC) projects, of which six are complete.

One completed project concerned the development of the capability of analytical laboratories. In this project, gamma spectrometry and x-ray fluorescence (XRF) capabilities were installed at the Central Laboratories of the Yemen Mineral Resources and Geological Survey at the Ministry of Oil and Mineral Resources. These laboratories

\footnotetext{
${ }^{704}$ Central Intelligence Agency. "Yemen," The World Factbook. Last updated 31 May 2007. Accessed 12 June 2007. https://www.cia.gov/library/publications/the-world-factbook/geos/ym.html

${ }^{705}$ Energy Information Administration. "Yemen: Natural Gas", U.S. Department of Energy, September 2006. Accessed 12 June 2007. http://www.eia.doe.gov/emeu/cabs/Yemen/NaturalGas.html

706 "List of IAEA Member States", International Atomic Energy Agency, March 2007. Accessed 6 June 2007. http://www.iaea.org/About/Policy/MemberStates/

${ }^{707}$ International Atomic Energy Agency. "Strengthened Safeguards System: Status of Additional Protocols," 22 March 2007. Accessed 5 June 2007.

http://www.iaea.org/OurWork/SV/Safeguards/sg_protocol.html

${ }^{708}$ Federation of American Scientists. Signatories and Parties to the Treaty on the Non-Proliferation of Nuclear Weapons. 3 December 1998. Accessed 5 June 2007. http://www.fas.org/nuke/control/npt/text/npt3.htm

${ }^{709}$ CTBTO Preparatory Commission. "Status of Signature and Ratification." 2007. Accessed 5 June 2007. http://www.ctbto.org

${ }^{710}$ International Atomic Energy Agency. "Safeguards Current Status", 16 May 2007. Accessed 5 June 2007. http://www.iaea.org/OurWork/SV/Safeguards/sir_table.pdf

${ }^{711}$ Barletta, Michael and Erik Jorgensen. "Weapons of Mass Destruction Capabilities and Programs:Yemen," Center for Nonproliferation Studies, last updated April 2006. Accessed 14 June 2007. http://cns.miis.edu/research/wmdme/yemen.htm
} 
function to develop techniques for determining the chemical composition and radioactivity of environmental and geological samples.

Another TC project established the National Centre for Radiation Oncology at the Al-Ghamhouri Teaching Hospital in Sana'a. The project included training in various aspects of radiation therapy, teletherapy, brachytherapy, chemoradiotherapy, medical oncology and nuclear medicine; as well as the purchase of instruments for modern radiation therapy for Yemeni cancer patients. The facility became operational in February 2005, and another project is underway for the establishment of a similar center in the City of Aden.

Other projects address areas of human resource development and nuclear technology support, radiation protection, agriculture and animal diseases, isotope hydrology, food and environmental monitoring, other nuclear medicine issues, and the establishment of a Centre for Non-destructive Testing. Most of the projects are carried out in conjunction with Yemen's National Atomic Energy Commission. ${ }^{712}$ On one agricultural project, the National Atomic Energy Commission reports remarkable results of nearly doubled production per area of land with less than half the water used. ${ }^{713}$

\section{REGIONAL PROJECT POSSIBILITIES}

Yemen's geographic location close to the Gulf Cooperation Council nations could allow for a joint program between the GCC and Yemen. Yemen has begun to establish some safeguards and export controls necessary for a nuclear program, and has shown commitment in its leadership to the development of nuclear energy. However, Yemen would benefit from the technical knowledge of Egypt or other Arab neighbors prior to establishing such a program. Yemen has already demonstrated interest in working with the United States and Canada, who could provide technical assistance as well as legislative guidance. Yemen's initial steps towards nuclear safeguards demonstrate commitment to working with the international community, for which the country should be commended, and further collaboration with international organizations, the GCC, and the United States will help strengthen Yemen's infrastructure for any future nuclear program developed.

\footnotetext{
712 International Atomic Energy Agency, “IAEA - TC Projects by Country.” Accessed 6 June 2007. http://www-tc.iaea.org/tcweb/tcprogramme/projectsbycountry/default.asp

${ }^{713}$ Bahran, Moustafa Y. "Upgrading Nuclear Safety and Security Infrastructure in Yemen," National Atomic Energy Commission. Accessed 14 June 2007. http://wwwpub.iaea.org/MTCD/Meetings/PDFplus/2007/cn142/cn142Papers/41_MY_Bahran.doc
} 


\section{APPENDICES}

\section{Appendix A. Summary of Egypt's Bilateral Treaties, Agreements, and}

Commitments. 714

\begin{tabular}{|l|r|r|r|r|}
\hline \multicolumn{1}{|c|}{ Commitments } & Signature & Ratification & Remaining into force & Renewal* \\
\hline 2- Bilateral & $27 / 03 / 1981$ & $14 / 07 / 1981$ & 30 years & 3 years, each \\
\hline 2-1 France & $29 / 06 / 1981$ & $29 / 12 / 1981$ & 40 years & 40 years \\
\hline 2-2 USA & $26 / 10 / 1981$ & $26 / 02 / 1982$ & 30 years & 5 years \\
\hline 2-3 Germany & $17 / 05 / 1982$ & $8 / 11 / 1982$ & 30 years & 5 years \\
\hline 2-4 Canada & $26 / 07 / 1981$ & & & \\
\hline 2-5 Australia & $10 / 04 / 1985$ & & & \\
\hline 2-6 South Korea & & & \\
\hline \multicolumn{5}{|l|}{} \\
\hline 3- Memorandum of Understanding & & \\
\hline 3-1 Sweden & $23 / 06 / 1981$ & & & \\
\hline 3-2 United Kingdom & $02 / 11 / 1981$ & & & \\
\hline
\end{tabular}

${ }^{714}$ IAEA Department of Nuclear Energy, "Country Nuclear Power Profiles: Egypt”, last updated Aug. 2005. Accessed 5 April 2007. http://wwwpub.iaea.org/MTCD/publications/PDF/cnpp2004/CNPP_Webpage/countryprofiles/Egypt/Egypt2005.htm 


\section{Appendix B. List of Egypt's Legal Multilateral Agreements and Safeguards Agreements. $^{715}$}

\begin{tabular}{|c|c|c|c|}
\hline \multicolumn{4}{|c|}{ Multilateral Agreements } \\
\hline & Title & \begin{tabular}{|c|} 
In \\
Force
\end{tabular} & Status \\
\hline P\&I & $\begin{array}{l}\text { Agreement on the Privileges and } \\
\text { Immunities of the IAEA }\end{array}$ & \begin{tabular}{|l|}
$1963-$ \\
$02-12$
\end{tabular} & acceptance: $1963-02-12$ \\
\hline $\mathrm{VC}$ & $\begin{array}{l}\text { Vienna Convention on Civil Liability for } \\
\text { Nuclear Damage }\end{array}$ & \begin{tabular}{|l|}
$1977-$ \\
$11-12$
\end{tabular} & $\begin{array}{l}\text { Signature: } 1965-08-19 \\
\text { ratification: } 1965-11-05\end{array}$ \\
\hline $\mathrm{VC} / \mathrm{OP}$ & $\begin{array}{l}\text { Optional Protocol Concerning the } \\
\text { Compulsory Settlement of Disputes }\end{array}$ & & Non-Party \\
\hline CPPNM & $\begin{array}{l}\text { Convention on the Physical Protection of } \\
\text { Nuclear Material }\end{array}$ & & Non-Party \\
\hline CPPNME & $\begin{array}{l}\text { Amendment to the Convention on the } \\
\text { Physical Protection of Nuclear Material }\end{array}$ & & Non-Party \\
\hline NOT & $\begin{array}{l}\text { Convention on Early Notification of a } \\
\text { Nuclear Accident }\end{array}$ & \begin{tabular}{|l|l|}
$1988-$ \\
$08-06$
\end{tabular} & $\begin{array}{l}\text { Signature: } 1986-09-26 \\
\text { ratification: } 1988-07-06\end{array}$ \\
\hline ASSIST & $\begin{array}{l}\text { Convention on Assistance in the Case of a } \\
\text { Nuclear Accident or Radiological } \\
\text { Emergency }\end{array}$ & \begin{tabular}{|l|}
$1988-$ \\
$11-17$
\end{tabular} & $\begin{array}{l}\text { Signature: } 1986-09-26 \\
\text { ratification: } 1988-10-17\end{array}$ \\
\hline JP & $\begin{array}{l}\text { Joint Protocol Relating to the Application } \\
\text { of the Vienna Convention and the Paris } \\
\text { Convention }\end{array}$ & $\begin{array}{l}1992- \\
04-27\end{array}$ & $\begin{array}{l}\text { Signature: } 1988-09-21 \\
\text { ratification: } 1989-08-10\end{array}$ \\
\hline NS & Convention on Nuclear Safety & & Signature: 1994-09-20 \\
\hline RADW & $\begin{array}{l}\text { Joint Convention on the Safety of Spent } \\
\text { Fuel Management and on the Safety of } \\
\text { Radioactive Waste Management }\end{array}$ & & Non-Party \\
\hline PVC & $\begin{array}{l}\text { Protocol to Amend the Vienna } \\
\text { Convention on Civil Liability for Nuclear } \\
\text { Damage }\end{array}$ & & Non-Party \\
\hline SUPP & $\begin{array}{l}\text { Convention on Supplementary } \\
\text { Compensation for Nuclear Damage }\end{array}$ & & Non-Party \\
\hline RSA & $\begin{array}{l}\text { Revised Supplementary Agreement } \\
\text { Concerning the Provision of Technical } \\
\text { Assistance by the IAEA (RSA) }\end{array}$ & \begin{tabular}{|l|}
$1980-$ \\
$06-04$
\end{tabular} & Signature: 1980-06-04 \\
\hline RCA & $\begin{array}{l}\text { Third Agreement to Extend the } 1987 \\
\text { Regional Co-operative Agreement for }\end{array}$ & & Non-Party \\
\hline
\end{tabular}

\footnotetext{
${ }^{715}$ IAEA Office of Legal Affairs. "Country Factsheets: Egypt, Arab Republic of,” 28 March 2006. Accessed 5 April 2007. http://ola.iaea.org/factSheets/CountryDetails.asp?country=EG
} 


\begin{tabular}{|l|l|l|l|} 
& $\begin{array}{l}\text { Research, Development and Training } \\
\text { Related to Nuclear Science and } \\
\text { Technology (RCA) }\end{array}$ & & \\
\hline AFRA & $\begin{array}{l}\text { African Regional Co-operative } \\
\text { Agreement for Research, Development } \\
\text { and Training Related to Nuclear Science } \\
\text { and Technology (AFRA) - Third } \\
\text { Extension }\end{array}$ & $\begin{array}{l}\text { 2005-06 } \\
\text { 04-06 }\end{array}$ & acceptance: 2005-04-06 \\
\hline ARCAL & $\begin{array}{l}\text { Co-operation Agreement for the } \\
\text { Promotion of Nuclear Science and } \\
\text { Technology in Latin America and the } \\
\text { Caribbean (ARCAL) }\end{array}$ & $\begin{array}{l}\text { Non-Party } \\
\text { Co-operative Agreement for Arab States } \\
\text { in Asia for Research, Development and } \\
\text { Training Related to Nuclear Science and } \\
\text { Technology (ARASIA) }\end{array}$ & Non-Party \\
\hline ARASIA & & \\
\hline
\end{tabular}

Safeguards Agreements

\begin{tabular}{|l|l|c|c|}
\hline Reg.No & \multicolumn{1}{|c|}{ Title } & $\begin{array}{c}\text { In } \\
\text { Force }\end{array}$ & \multicolumn{1}{c|}{ Status } \\
\hline 1472 & $\begin{array}{l}\text { Application of Safeguards in connection with } \\
\text { the Treaty on the Non-Proliferation of } \\
\text { Nuclear Weapons }\end{array}$ & $\begin{array}{l}\text { 1982- } \\
\text { 06-30 }\end{array}$ & Signature: 1981-10-07 \\
\hline
\end{tabular}




\section{Appendix C. List of Jordan's Legal Multilateral Agreements and Safeguards Agreements. $^{716}$}

\begin{tabular}{|c|c|c|c|}
\hline \multicolumn{4}{|c|}{ Aultilateral Agreements } \\
\hline & Title & \begin{tabular}{|c|} 
In \\
Force
\end{tabular} & Status \\
\hline P\&I & $\begin{array}{l}\text { Agreement on the Privileges and } \\
\text { Immunities of the IAEA }\end{array}$ & \begin{tabular}{|l|}
$1982-$ \\
$10-27$ \\
\end{tabular} & acceptance: $1982-10-27$ \\
\hline $\mathrm{VC}$ & $\begin{array}{l}\text { Vienna Convention on Civil Liability for } \\
\text { Nuclear Damage }\end{array}$ & & Non-Party \\
\hline VC/OP & $\begin{array}{l}\text { Optional Protocol Concerning the } \\
\text { Compulsory Settlement of Disputes }\end{array}$ & & Non-Party \\
\hline CPPNM & $\begin{array}{l}\text { Convention on the Physical Protection of } \\
\text { Nuclear Material }\end{array}$ & & Non-Party \\
\hline CPPNME & $\begin{array}{l}\text { Amendment to the Convention on the } \\
\text { Physical Protection of Nuclear Material }\end{array}$ & & Non-Party \\
\hline NOT & $\begin{array}{l}\text { Convention on Early Notification of a } \\
\text { Nuclear Accident }\end{array}$ & \begin{tabular}{|l|}
$1988-$ \\
$01-11$ \\
\end{tabular} & $\begin{array}{l}\text { Signature: } 1986-10-02 \\
\text { ratification: } 1987-12-11\end{array}$ \\
\hline ASSIST & $\begin{array}{l}\text { Convention on Assistance in the Case of a } \\
\text { Nuclear Accident or Radiological } \\
\text { Emergency }\end{array}$ & \begin{tabular}{|l|}
$1988-$ \\
$01-11$
\end{tabular} & $\begin{array}{l}\text { Signature: } 1986-10-02 \\
\text { ratification: } 1987-12-11\end{array}$ \\
\hline $\mathrm{JP}$ & $\begin{array}{l}\text { Joint Protocol Relating to the Application } \\
\text { of the Vienna Convention and the Paris } \\
\text { Convention }\end{array}$ & & Non-Party \\
\hline NS & Convention on Nuclear Safety & & Signature: 1994-12-06 \\
\hline RADW & $\begin{array}{l}\text { Joint Convention on the Safety of Spent } \\
\text { Fuel Management and on the Safety of } \\
\text { Radioactive Waste Management }\end{array}$ & & Non-Party \\
\hline PVC & $\begin{array}{l}\text { Protocol to Amend the Vienna } \\
\text { Convention on Civil Liability for Nuclear } \\
\text { Damage }\end{array}$ & & Non-Party \\
\hline SUPP & $\begin{array}{l}\text { Convention on Supplementary } \\
\text { Compensation for Nuclear Damage }\end{array}$ & & Non-Party \\
\hline RSA & $\begin{array}{l}\text { Revised Supplementary Agreement } \\
\text { Concerning the Provision of Technical } \\
\text { Assistance by the IAEA (RSA) }\end{array}$ & \begin{tabular}{|l|}
$1989-$ \\
$02-05$
\end{tabular} & Signature: 1989-02-05 \\
\hline RCA & $\begin{array}{l}\text { Third Agreement to Extend the } 1987 \\
\text { Regional Co-operative Agreement for }\end{array}$ & & Non-Party \\
\hline
\end{tabular}

\footnotetext{
${ }^{716}$ IAEA Office of Legal Affairs. "Country Factsheets: Jordan, Hashemite Kingdom of," 28 March 2006. Accessed 5 April 2007. http://ola.iaea.org/factSheets/CountryDetails.asp?country=JO
} 


\begin{tabular}{|l|l|l|l|} 
& $\begin{array}{l}\text { Research, Development and Training } \\
\text { Related to Nuclear Science and } \\
\text { Technology (RCA) }\end{array}$ & & \\
\hline AFRA & $\begin{array}{l}\text { African Regional Co-operative } \\
\text { Agreement for Research, Development } \\
\text { and Training Related to Nuclear Science } \\
\text { and Technology (AFRA) - Third } \\
\text { Extension }\end{array}$ & Non-Party \\
\hline ARCAL & $\begin{array}{l}\text { Co-operation Agreement for the } \\
\text { Promotion of Nuclear Science and } \\
\text { Technology in Latin America and the } \\
\text { Caribbean (ARCAL) }\end{array}$ & Non-Party \\
\hline ARASIA & $\begin{array}{l}\text { Co-operative Agreement for Arab States } \\
\text { in Asia for Research, Development and } \\
\text { Training Related to Nuclear Science and } \\
\text { Technology (ARASIA) }\end{array}$ & $\begin{array}{l}\text { 2002-20 } \\
\text { Terionstance: 2002-08-20 }\end{array}$ \\
\hline
\end{tabular}

\begin{tabular}{|l|l|l|l|}
\hline Safeguards Agreements & \multicolumn{1}{|c|}{ Title } & $\begin{array}{c}\text { In } \\
\text { Force }\end{array}$ & \multicolumn{1}{|c|}{ Status } \\
\hline 1297 & $\begin{array}{l}\text { Application of safeguards in connection with } \\
\text { the Treaty on Non-Proliferation of Nuclear } \\
\text { Weapons (with Protocol) }\end{array}$ & $\begin{array}{c}1978- \\
02-21\end{array}$ & Signature: 1974-12-05 \\
\hline 1701 & $\begin{array}{l}\text { Protocol Additional to the Agreement } \\
\text { between the Hashemite Kingdom of Jordan } \\
\text { and the IAEA for the Application of } \\
\text { Safeguards in Connection with the Treaty on } \\
\text { the Non-Proliferation of Nuclear Weapons }\end{array}$ & $\begin{array}{l}1998- \\
07-28\end{array}$ & Signature: 1998-07-28 \\
\hline
\end{tabular}




\section{Appendix D. Nuclear-related International, Multilateral and Bilateral Agreements of Turkey. ${ }^{717}$}

\author{
AGREEMENTS WITH THE IAEA \\ NPT related Agreement (INFCIRC/295) \\ Additional protocol \\ Improved procedures for designation of safeguards inspectors \\ Supplementary agreement on provision of technical \\ assistance by IAEA \\ EURATOM
}

RCA

Agreement on privileges and immunities

MAIN INTERNATIONAL TREATIES and CONVENTIONS.

NPT

Convention on physical protection of nuclear material

Convention on early notification of a nuclear accident

Convention on assistance in the case of a nuclear accident or radiological emergency

$\begin{array}{ll}\text { Entry into } & 1 \text { September } \\ \text { force: } & 1981\end{array}$

Signed on: $\quad 6$ July 2000

Accepted on: 18 January 1989

Entry into $\quad 11$ November

force: $\quad 1980$

Entry into September 1984

force:

Non-Party

Entry into

26 June 1978

force:
Entry into

17 April 1980

force:

Entry into force:

Entry into force:

Entry into force:

${ }^{717}$ IAEA Department of Nuclear Energy, “Country Nuclear Power Profiles: Turkey”, last updated August 2005. Accessed 10 April 2007. http://wwwpub.iaea.org/MTCD/publications/PDF/cnpp2004/CNPP_Webpage/countryprofiles/Turkey/Turkey2004.htm 
Paris convention on civil liability for nuclear damage

Joint protocol relating to the application of the Vienna and the Paris conventions

Protocol to amend the Vienna convention on civil liability for nuclear damage

Convention on supplementary compensation for nuclear damage

Convention on nuclear safety

Joint convention on the safety of spent fuel management and on the safety of radioactive waste management

\section{OTHER RELEVANT INTERNATIONAL AGREEMENTS}

ZANGGER Committee

Nuclear Export Guidelines (INFCIRC/254)

Acceptance of NUSS Codes

Nuclear Suppliers Group

International convention No: 42 on the compensation of professional disease

Convention on the co-operation in the atomic energy field between the NATO members and its amendment

Convention on the establishment of a security control in the field of nuclear energy, protocol on the establishment of a court and convention on the European company for the chemical separation of radioactive fuel (EUROCHIME)

Treaty banning nuclear weapons tests in the atmosphere, in outer space and under water (Limited or Partial Test Ban Treaty)
Entry into

force:

Signature:

21 September 1988

Not signed

Not signed

Entry into

24 October 1996

force:

Not signed

Member

21 October 1999

Adopted

Letter of:

31 October 1988

Member

20 April 2000

Ratification:

16 February 1946

Signature: $\quad 22$ June 1955

Ratification: 1 September

1956

Signature: 20 December Ratification: $\quad 1957$

25 May 1959

Signature: $\quad 5$ August 1963

Ratification: 13 May 1965 
International labor conference convention number 115

Ratification: $\quad 7$ March 1968

concerning the protection of workers against ionizing radiations

Treaty on the prohibition of the emplacement of nuclear

Ratification: $\quad 27$ April 1972 weapons and other weapons of mass destruction on the seabed and ocean floor and in the subsoil thereof

Convention for the protection of the Mediterranean Sea against pollution

$\begin{array}{ll}\text { Signature: } & \text { 16 February } \\ \text { Ratification: } & \text { 1976 } \\ & \text { RG: } 12 \text { June } \\ & 1981\end{array}$

Protocol for the protection of the Mediterranean Sea against

Ratification: $\quad 18$ March 1987 pollution from land originated sources

The international convention on railway transportation

Ratification: 21 March 1985

Convention on the protection of the Black Sea against pollution

Ratification: 7 December 1993

Comprehensive test ban treaty

Signature: $\quad 24$ September

Ratification: $\quad 1996$

16 February

2000

\section{BILATERAL AGREEMENTS}

Agreement For Cooperation Concerning Civil Uses of Atomic Energy Between the Government of Turkey and the USA

Signature: 10 June 1955 Ratification date: 4 December 1956

Several amendments and revisions: (1956-1981)

Extension: (1981-1985)

Termination: 1985

Agreement Between The Government of Canada and The Government of Turkey for Cooperation in The Peaceful Uses of Nuclear Energy

Signature: 18 June 1985

Ratification: 23 February 1986

Agreement Between The Government of Argentina and The Government of Turkey for Cooperation in The Peaceful Uses of Nuclear Energy

Signature: 3 May 1988 
Ratification date: 21 May 1991

Agreement Between The Government of South Korea and The Government of Turkey for Cooperation in The Peaceful Uses of Nuclear Energy

Signature: 26 October 1998

Agreement Between The Government of Germany and The Government of Turkey for Cooperation in The Peaceful Uses of Nuclear Energy

Initialed: 14 January 1998

Agreement Between The Government of France and The Government of Turkey for Cooperation in The Peaceful Uses of Nuclear Energy

Signature: 21 September 1999

Ratified: 14 January 2004

Agreement Between The Government of USA and The Government of Turkey for Cooperation in The Peaceful Uses of Nuclear Energy

Signature: 19 November 1999

Ratification: 14 January 2004

\section{BILATERAL AGREEMENTS ON EARLY NOTIFICATION}

Agreement Between The Government of Republic of Bulgaria and The Government of Republic of Turkey on Early Notification of a Nuclear Accident and on Exchange of Information on Nuclear Facilities

Signature: 28 July 97

Ratification: 11 Sept. 1997

Agreement Between The cabinet of ministries of Ukraine and The Government of Republic of Turkey on Early Notification of a Nuclear Accident and on Exchange of Information on Nuclear Facilities

Signature: 23 November 2000

Agreement Between The Government of Russia and The Government of Republic of Turkey on Early Notification of a Nuclear Accident And on Exchange of Information on Nuclear Facilities Initialed: 29 July 1988

Agreement Between The Government of Romania and The Government of Republic of Turkey on Early Notification of a Nuclear Accident And on Exchange of Information on Nuclear Facilities and for Cooperation in The Peaceful Uses of Nuclear Energy.

Initialed: 14 September 1993 


\section{Appendix E. List of Turkey's Legal Multilateral Agreements and Safeguards Agreements. $^{718}$}

\begin{tabular}{|c|c|c|c|}
\hline \multicolumn{4}{|c|}{ Multilateral Agreements } \\
\hline & Title & $\begin{array}{c}\text { In } \\
\text { Force }\end{array}$ & Status \\
\hline P\&I & $\begin{array}{l}\text { Agreement on the Privileges and } \\
\text { Immunities of the IAEA }\end{array}$ & $\begin{array}{ll}1978- \\
06-26\end{array}$ & acceptance: $1978-06-26$ \\
\hline $\mathrm{VC}$ & $\begin{array}{l}\text { Vienna Convention on Civil Liability for } \\
\text { Nuclear Damage }\end{array}$ & & Non-Party \\
\hline $\mathrm{VC} / \mathrm{OP}$ & $\begin{array}{l}\text { Optional Protocol Concerning the } \\
\text { Compulsory Settlement of Disputes }\end{array}$ & & Non-Party \\
\hline CPPNM & $\begin{array}{l}\text { Convention on the Physical Protection of } \\
\text { Nuclear Material }\end{array}$ & $\begin{array}{l}1987- \\
02-08\end{array}$ & $\begin{array}{l}\text { Signature: } 1983-08-23 \\
\text { ratification: } 1985-02-27\end{array}$ \\
\hline CPPNME & $\begin{array}{l}\text { Amendment to the Convention on the } \\
\text { Physical Protection of Nuclear Material }\end{array}$ & & Non-Party \\
\hline NOT & $\begin{array}{l}\text { Convention on Early Notification of a } \\
\text { Nuclear Accident }\end{array}$ & $\begin{array}{ll}1991- \\
02-03\end{array}$ & $\begin{array}{l}\text { Signature: } 1986-09-26 \\
\text { ratification: } 1991-01-03\end{array}$ \\
\hline ASSIST & $\begin{array}{l}\text { Convention on Assistance in the Case of a } \\
\text { Nuclear Accident or Radiological } \\
\text { Emergency }\end{array}$ & $\begin{array}{ll}1991- \\
02-03\end{array}$ & $\begin{array}{l}\text { Signature: } 1986-09-26 \\
\text { ratification: } 1991-01-03\end{array}$ \\
\hline JP & $\begin{array}{l}\text { Joint Protocol Relating to the Application } \\
\text { of the Vienna Convention and the Paris } \\
\text { Convention }\end{array}$ & $\begin{array}{l}2007- \\
06-26\end{array}$ & $\begin{array}{l}\text { Signature: } 1988-09-21 \\
\text { ratification: } 2007-03-26\end{array}$ \\
\hline NS & Convention on Nuclear Safety & \begin{tabular}{|l|l|}
$1996-$ \\
$10-24$ \\
\end{tabular} & $\begin{array}{l}\text { Signature: } 1994-09-20 \\
\text { ratification: } 1995-03-08\end{array}$ \\
\hline RADW & $\begin{array}{l}\text { Joint Convention on the Safety of Spent } \\
\text { Fuel Management and on the Safety of } \\
\text { Radioactive Waste Management }\end{array}$ & & Non-Party \\
\hline PVC & $\begin{array}{l}\text { Protocol to Amend the Vienna } \\
\text { Convention on Civil Liability for Nuclear } \\
\text { Damage }\end{array}$ & & Non-Party \\
\hline SUPP & $\begin{array}{l}\text { Convention on Supplementary } \\
\text { Compensation for Nuclear Damage }\end{array}$ & & Non-Party \\
\hline RSA & $\begin{array}{l}\text { Revised Supplementary Agreement } \\
\text { Concerning the Provision of Technical } \\
\text { Assistance by the IAEA (RSA) }\end{array}$ & $\begin{array}{l}1980- \\
11-11\end{array}$ & Signature: $1980-11-11$ \\
\hline
\end{tabular}

\footnotetext{
${ }^{718}$ IAEA Office of Legal Affairs. "Country Factsheets: Turkey, Republic of," 28 March 2006. Accessed 11 April 2007. http://ola.iaea.org/factSheets/CountryDetails.asp?country=TU
} 


\begin{tabular}{|l|l|l|l|}
\hline RCA & $\begin{array}{l}\text { Third Agreement to Extend the 1987 } \\
\text { Regional Co-operative Agreement for } \\
\text { Research, Development and Training } \\
\text { Related to Nuclear Science and } \\
\text { Technology (RCA) }\end{array}$ & Non-Party \\
\hline AFRA & $\begin{array}{l}\text { African Regional Co-operative Agreement } \\
\text { for Research, Development and Training } \\
\text { Related to Nuclear Science and } \\
\text { Technology (AFRA) - Third Extension }\end{array}$ & Non-Party \\
\hline ARCAL & $\begin{array}{l}\text { Co-operation Agreement for the } \\
\text { Promotion of Nuclear Science and } \\
\text { Technology in Latin America and the } \\
\text { Caribbean (ARCAL) }\end{array}$ & Non-Party \\
\hline ARASIA & $\begin{array}{l}\text { Co-operative Agreement for Arab States } \\
\text { in Asia for Research, Development and } \\
\text { Training Related to Nuclear Science and } \\
\text { Technology (ARASIA) }\end{array}$ & Non-Party \\
\hline
\end{tabular}

\begin{tabular}{|c|c|c|c|}
\hline \multicolumn{4}{|c|}{ Safeguards Agreements } \\
\hline Reg.No & Title & $\begin{array}{c}\text { In } \\
\text { Force }\end{array}$ & Status \\
\hline 1454 & $\begin{array}{l}\text { Application of safeguards in connection with } \\
\text { the Treaty on the Non-Proliferation of } \\
\text { Nuclear Weapons }\end{array}$ & $\begin{array}{l}1981- \\
09-01\end{array}$ & Signature: 1981-06-30 \\
\hline 1730 & $\begin{array}{l}\text { Protocol Additional to the Agreement } \\
\text { between the Government of the Republic of } \\
\text { Turkey and the International Atomic Energy } \\
\text { Agency for the Application of Safeguards in } \\
\text { Connection with the Treaty on the Non- } \\
\text { Proliferation of Nuclear Weapons }\end{array}$ & $\begin{array}{l}2001- \\
07-17\end{array}$ & Signature: 2000-07-06 \\
\hline
\end{tabular}




\section{Appendix F. List of Morocco's Legal Multilateral Agreements and Safeguards Agreements. $^{719}$}

\begin{tabular}{|c|c|c|c|}
\hline & Title & $\begin{array}{c}\text { In } \\
\text { Force }\end{array}$ & Status \\
\hline P\&I & $\begin{array}{l}\text { Agreement on the Privileges and } \\
\text { Immunities of the IAEA }\end{array}$ & $\begin{array}{l}1977- \\
03-30\end{array}$ & acceptance: 1977-03-30 \\
\hline $\mathrm{VC}$ & $\begin{array}{l}\text { Vienna Convention on Civil Liability for } \\
\text { Nuclear Damage }\end{array}$ & & Signature: 1984-11-30 \\
\hline $\mathrm{VC} / \mathrm{OP}$ & $\begin{array}{l}\text { Optional Protocol Concerning the } \\
\text { Compulsory Settlement of Disputes }\end{array}$ & & Non-Party \\
\hline CPPNM & $\begin{array}{l}\text { Convention on the Physical Protection of } \\
\text { Nuclear Material }\end{array}$ & $\begin{array}{l}2002- \\
09-22\end{array}$ & $\begin{array}{l}\text { Signature: } 1980-07-25 \\
\text { ratification: } 2002-08-23\end{array}$ \\
\hline CPPNME & $\begin{array}{l}\text { Amendment to the Convention on the } \\
\text { Physical Protection of Nuclear Material }\end{array}$ & & Non-Party \\
\hline NOT & $\begin{array}{l}\text { Convention on Early Notification of a } \\
\text { Nuclear Accident }\end{array}$ & $\begin{array}{l}1993- \\
11-07\end{array}$ & $\begin{array}{l}\text { Signature: } 1986-09-26 \\
\text { ratification: } 1993-10-07\end{array}$ \\
\hline ASSIST & $\begin{array}{l}\text { Convention on Assistance in the Case of a } \\
\text { Nuclear Accident or Radiological } \\
\text { Emergency }\end{array}$ & $\begin{array}{l}1993- \\
11-07\end{array}$ & $\begin{array}{l}\text { Signature: } 1986-09-26 \\
\text { ratification: } 1993-10-07\end{array}$ \\
\hline JP & $\begin{array}{l}\text { Joint Protocol Relating to the Application } \\
\text { of the Vienna Convention and the Paris } \\
\text { Convention }\end{array}$ & & Signature: 1988-09-21 \\
\hline NS & Convention on Nuclear Safety & & Signature: 1994-12-01 \\
\hline RADW & $\begin{array}{l}\text { Joint Convention on the Safety of Spent } \\
\text { Fuel Management and on the Safety of } \\
\text { Radioactive Waste Management }\end{array}$ & $\begin{array}{l}2001- \\
06-18\end{array}$ & $\begin{array}{l}\text { Signature: } 1997-09-29 \\
\text { ratification: } 1999-07-23\end{array}$ \\
\hline $\mathrm{PVC}$ & $\begin{array}{l}\text { Protocol to Amend the Vienna } \\
\text { Convention on Civil Liability for Nuclear } \\
\text { Damage }\end{array}$ & $\begin{array}{l}2003- \\
10-04\end{array}$ & $\begin{array}{l}\text { Signature: 1997-09-29 } \\
\text { ratification: 1999-07-06 }\end{array}$ \\
\hline SUPP & $\begin{array}{l}\text { Convention on Supplementary } \\
\text { Compensation for Nuclear Damage }\end{array}$ & & $\begin{array}{l}\text { Signature: } 1997-09-29 \\
\text { ratification: } 1999-07-06\end{array}$ \\
\hline RSA & $\begin{array}{l}\text { Revised Supplementary Agreement } \\
\text { Concerning the Provision of Technical } \\
\text { Assistance by the IAEA (RSA) }\end{array}$ & $\begin{array}{l}1989- \\
03-20\end{array}$ & Signature: 1989-03-20 \\
\hline $\mathrm{RCA}$ & $\begin{array}{l}\text { Third Agreement to Extend the } 1987 \\
\text { Regional Co-operative Agreement for }\end{array}$ & & Non-Party \\
\hline
\end{tabular}

\footnotetext{
${ }^{719}$ IAEA Office of Legal Affairs. "Country Factsheets: Morocco, Kingdom of," 28 March 2006. Accessed 23 April 2007. http://ola.iaea.org/factSheets/CountryDetails.asp?country=MA
} 


\begin{tabular}{|l|l|l|l|} 
& $\begin{array}{l}\text { Research, Development and Training } \\
\text { Related to Nuclear Science and } \\
\text { Technology (RCA) }\end{array}$ & & \\
\hline AFRA & $\begin{array}{l}\text { African Regional Co-operative } \\
\text { Agreement for Research, Development } \\
\text { and Training Related to Nuclear Science } \\
\text { and Technology (AFRA) - Third } \\
\text { Extension }\end{array}$ & $\begin{array}{l}\text { 2005- } \\
\text { 06-20 }\end{array}$ & acceptance: 2005-06-20 \\
\hline ARCAL & $\begin{array}{l}\text { Co-operation Agreement for the } \\
\text { Promotion of Nuclear Science and } \\
\text { Technology in Latin America and the } \\
\text { Caribbean (ARCAL) }\end{array}$ & Non-Party \\
\hline ARASIA & $\begin{array}{l}\text { Co-operative Agreement for Arab States } \\
\text { in Asia for Research, Development and } \\
\text { Training Related to Nuclear Science and } \\
\text { Technology (ARASIA) }\end{array}$ & Non-Party \\
\hline
\end{tabular}

Safeguards Agreements

\begin{tabular}{|l|l|c|c|}
\hline Reg.No & \multicolumn{1}{|c|}{ Title } & $\begin{array}{c}\text { In } \\
\text { Force }\end{array}$ & \multicolumn{1}{|c|}{ Status } \\
\hline 1136 & $\begin{array}{l}\text { Application of safeguards in connection with } \\
\text { the Treaty on Non-Proliferation of Nuclear } \\
\text { Weapons (with Protocol) }\end{array}$ & $\begin{array}{c}1975-18 \\
02-18\end{array}$ & Signature: 1973-01-30 \\
\hline
\end{tabular}




\section{Appendix G. A Brief Summary of the History of U.S. Relations with Libya. ${ }^{720}$}

December 24, Libya becomes independent with U.S. support

1951

September 1969 Military overthrow of the Libyan government; Qadhafi becomes chief of state a few months later.

1972

The U.S. withdraws its ambassador due to increasingly strained foreign policies with Qadhafi's regime.

April 16, 1973

December, 1979

Qadhafi declares a "cultural revolution".

US embassy staff members are withdrawn from Tripoli after a mob attacks and sets fire to the embassy. The U.S. Government declares Libya a "state sponsor of terrorism" on the 29th.

August 19, 1981 Two Libyan jets fire on U.S. aircraft participating in a routine naval exercise over international waters of the Mediterranean claimed by Libya. The U.S. planes return fire and shoot down the attacking Libyan aircraft.

April, 1984

An eleven-day Libyan embassy siege in London kills one; Libya admits responsibility in 1999.

January, 1986 The U.S. Government institutes a total ban on direct import and export trade, commercial contracts, and travel-related activities. In addition, Libyan Government assets in the United States are frozen. This amounts to a culmination of embargoes increasingly imposed since 1982.

March, $1986 \quad$ Lingering maritime border disputes result in two Libyan boats sunk by the U.S. in Gulf of Sirte, off the coast of Libya.

April 5, 1986

A West Berlin nightclub, a favorite of US servicemen, is bombed, killing three and injuring 230. In 1996, three Libyan embassy workers are convicted of planning the bombing.

April 15-16, 1986 US warplanes launch a series of military strikes from British Bases against Tripoli and Benghazi, killing at least 60.

\footnotetext{
${ }^{720}$ With resources used from the following sources (websites accessed 25 April 2007):

- Blum, Yehuda Z. "The Gulf of Sidra Incident," The American Journal of International Law. 1986

- Bureau of Near Eastern Affairs. "Background Notes: Libya,” U.S. Department of State, February 2007. http://www.state.gov/r/pa/ei/bgn/5425.htm

- Central Intelligence Agency. "Libya," The World Factbook. Last updated 17 April, 2007. https:/www.cia.gov/library/publications/the-world-factbook/geos/ly.html

- Kaplan, Eden. "How Libya Got Off the List," Council on Foreign Relations, 8 June 2006.

http://www.cfr.org/publication/10855/how libya got off the list.html

- Reynolds, Paul. "UTA 722: The Forgotten Flight," ${ }_{B} B \bar{C}$ News Online, 19 August 2003.

http://news.bbc.co.uk/1/hi/uk/3163621.stm

- “1986: Berlin disco bombed,” On This Day, BBC News. 5 April 1986.

http://news.bbc.co.uk/onthisday/hi/dates/stories/april/5/newsid_4357000/4357255.stm
} 
December 21, Transatlantic flight Pan Am 103 explodes and the plane crashes over 1988 Lockerbie, Scotland, killing 270 people from 21 countries, of whom 189 are Americans. Among the casualties are several U.S. intelligence agents, a senior army officer, and two security agents for the U.S. Embassy in Beirut. Two Libyan terrorists are indicted for their involvement in 1991.

September 1989

August, 2003

September 2003

December 2003

February 8, 2004

September 2004

May 31, 2006

June 30, 2006
19, French UTA flight 772 is blown up over the Sahara Desert, killing 171. Six Libyans are convicted in the case, including Qadhafi's brother-in-law, who was head of Libya's external intelligence division; this act was allegedly in revenge for France's support of Chad in a border dispute.

Libya provides compensation to families affected by deaths in Pan Am flight 103 and UTA flight 772, as well as that of the woman killed in the embassy siege; in a letter to the UN, it accepts responsibility for the attack and renounces terrorism in all forms.

12, UN lifts sanctions on Libya, imposed in 1992, after it fulfilled all remaining UNSCR requirements, including renunciation of terrorism, acceptance of responsibility for the actions of its officials, and payment of appropriate compensation to the victims' families.

19, Libya declares its intention to reveal and to rid itself of WMD and MTCRclass missile programs.

U.S. diplomatic officials reopen the U.S. Interest Section in Tripoli.

20, U.S. economic sanctions are lifted; certain export controls remain in place.

U.S. mission to Tripoli is upgraded to a full embassy.

U.S. removes Libya from the list of state sponsors of terrorism in recognition of the fact that Libya had met the statutory requirements for such a move: it had not provided any support for acts of international terrorism in the preceding six-month period, and had provided assurances that it would not do so in the future. 
Appendix H. Libya's Multilateral and Safeguards Agreements. ${ }^{721}$

\begin{tabular}{|c|c|c|c|}
\hline & Title & $\begin{array}{c}\text { In } \\
\text { Force }\end{array}$ & Status \\
\hline P\&I & $\begin{array}{l}\text { Agreement on the Privileges and } \\
\text { Immunities of the IAEA }\end{array}$ & & Non-Party \\
\hline VC & $\begin{array}{l}\text { Vienna Convention on Civil Liability for } \\
\text { Nuclear Damage }\end{array}$ & & Non-Party \\
\hline $\mathrm{VC} / \mathrm{OP}$ & $\begin{array}{l}\text { Optional Protocol Concerning the } \\
\text { Compulsory Settlement of Disputes }\end{array}$ & & Non-Party \\
\hline CPPNM & $\begin{array}{l}\text { Convention on the Physical Protection of } \\
\text { Nuclear Material }\end{array}$ & \begin{tabular}{|l|}
$2000-$ \\
$11-17$
\end{tabular} & accession: $2000-10-18$ \\
\hline CPPNME & $\begin{array}{l}\text { Amendment to the Convention on the } \\
\text { Physical Protection of Nuclear Material }\end{array}$ & & ratification: 2006-07-19 \\
\hline NOT & $\begin{array}{l}\text { Convention on Early Notification of a } \\
\text { Nuclear Accident }\end{array}$ & & Non-Party \\
\hline ASSIST & $\begin{array}{l}\text { Convention on Assistance in the Case of a } \\
\text { Nuclear Accident or Radiological } \\
\text { Emergency }\end{array}$ & $\begin{array}{l}1990- \\
07-28\end{array}$ & accession: 1990-06-27 \\
\hline $\mathrm{JP}$ & $\begin{array}{l}\text { Joint Protocol Relating to the Application } \\
\text { of the Vienna Convention and the Paris } \\
\text { Convention }\end{array}$ & & Non-Party \\
\hline NS & Convention on Nuclear Safety & & Non-Party \\
\hline RADW & $\begin{array}{l}\text { Joint Convention on the Safety of Spent } \\
\text { Fuel Management and on the Safety of } \\
\text { Radioactive Waste Management }\end{array}$ & & Non-Party \\
\hline PVC & $\begin{array}{l}\text { Protocol to Amend the Vienna } \\
\text { Convention on Civil Liability for Nuclear } \\
\text { Damage }\end{array}$ & & Non-Party \\
\hline SUPP & $\begin{array}{l}\text { Convention on Supplementary } \\
\text { Compensation for Nuclear Damage }\end{array}$ & & Non-Party \\
\hline RSA & $\begin{array}{l}\text { Revised Supplementary Agreement } \\
\text { Concerning the Provision of Technical } \\
\text { Assistance by the IAEA (RSA) }\end{array}$ & $\begin{array}{l}1990- \\
04-23\end{array}$ & Signature: 1990-04-23 \\
\hline $\mathrm{RCA}$ & Third Agreement to Extend the 1987 & & Non-Party \\
\hline
\end{tabular}

${ }^{721}$ Office of Legal Affairs. "Libyan Arab Jamahiriya, Socialist People's", Country Factsheets, IAEA. Last updated 31 July 2006. Accessed 30 April 2007.

http://ola.iaea.org/factSheets/CountryDetails.asp?country=LY 


\begin{tabular}{|l|l|l|l|} 
& $\begin{array}{l}\text { Regional Co-operative Agreement for } \\
\text { Research, Development and Training } \\
\text { Related to Nuclear Science and } \\
\text { Technology (RCA) }\end{array}$ & & \\
\hline AFRA & $\begin{array}{l}\text { African Regional Co-operative } \\
\text { Agreement for Research, Development } \\
\text { and Training Related to Nuclear Science } \\
\text { and Technology (AFRA) - Third } \\
\text { Extension }\end{array}$ & $\begin{array}{l}\text { 2005-04 } \\
\text { Ex-0 }\end{array}$ & acceptance: 2005-03-31 \\
\hline ARCAL & $\begin{array}{l}\text { Co-operation Agreement for the } \\
\text { Promotion of Nuclear Science and } \\
\text { Technology in Latin America and the } \\
\text { Caribbean (ARCAL) }\end{array}$ & Non-Party \\
\hline ARASIA & $\begin{array}{l}\text { Co-operative Agreement for Arab States } \\
\text { in Asia for Research, Development and } \\
\text { Training Related to Nuclear Science and } \\
\text { Technology (ARASIA) }\end{array}$ & Non-Party \\
\hline
\end{tabular}

Safeguards Agreements

\begin{tabular}{|c|c|c|c|}
\hline Reg.No & Title & $\begin{array}{c}\text { In } \\
\text { Force }\end{array}$ & Status \\
\hline 1403 & $\begin{array}{l}\text { Application of safeguards in connection with } \\
\text { the Treaty on Non-Proliferation of Nuclear } \\
\text { Weapons }\end{array}$ & $\begin{array}{l}1980- \\
07-08\end{array}$ & Signature: $1980-07-08$ \\
\hline 1806 & $\begin{array}{l}\text { Protocol Additional to the Agreement } \\
\text { between the Socialist People's Libyan Arab } \\
\text { Jamahiriya and the International Atomic } \\
\text { Energy Agency for the Application of } \\
\text { Safeguards in connection with the Treaty on } \\
\text { the Non-Proliferation of Nuclear Weapons }\end{array}$ & $\begin{array}{l}\text { 2006- } \\
08-11\end{array}$ & Signature: 2004-03-10 \\
\hline
\end{tabular}


Appendix I. Saudi Arabia’s Multilateral and Safeguards Agreements. ${ }^{722}$

\begin{tabular}{|c|c|c|c|}
\hline & Title & $\begin{array}{c}\text { In } \\
\text { Force }\end{array}$ & Status \\
\hline P\&I & $\begin{array}{l}\text { Agreement on the Privileges and } \\
\text { Immunities of the IAEA }\end{array}$ & & Non-Party \\
\hline $\mathrm{VC}$ & $\begin{array}{l}\text { Vienna Convention on Civil Liability for } \\
\text { Nuclear Damage }\end{array}$ & & Non-Party \\
\hline $\mathrm{VC} / \mathrm{OP}$ & $\begin{array}{l}\text { Optional Protocol Concerning the } \\
\text { Compulsory Settlement of Disputes }\end{array}$ & & Non-Party \\
\hline CPPNM & $\begin{array}{l}\text { Convention on the Physical Protection of } \\
\text { Nuclear Material }\end{array}$ & & Non-Party \\
\hline CPPNME & $\begin{array}{l}\text { Amendment to the Convention on the } \\
\text { Physical Protection of Nuclear Material }\end{array}$ & & Non-Party \\
\hline NOT & $\begin{array}{l}\text { Convention on Early Notification of a } \\
\text { Nuclear Accident }\end{array}$ & $\begin{array}{l}1989- \\
12-04\end{array}$ & accession: 1989-11-03 \\
\hline ASSIST & $\begin{array}{l}\text { Convention on Assistance in the Case of a } \\
\text { Nuclear Accident or Radiological } \\
\text { Emergency }\end{array}$ & $\begin{array}{l}1989- \\
12-04\end{array}$ & accession: 1989-11-03 \\
\hline JP & $\begin{array}{l}\text { Joint Protocol Relating to the Application } \\
\text { of the Vienna Convention and the Paris } \\
\text { Convention }\end{array}$ & & Non-Party \\
\hline NS & Convention on Nuclear Safety & & Non-Party \\
\hline RADW & $\begin{array}{l}\text { Joint Convention on the Safety of Spent } \\
\text { Fuel Management and on the Safety of } \\
\text { Radioactive Waste Management }\end{array}$ & & Non-Party \\
\hline PVC & $\begin{array}{l}\text { Protocol to Amend the Vienna } \\
\text { Convention on Civil Liability for Nuclear } \\
\text { Damage }\end{array}$ & & Non-Party \\
\hline SUPP & $\begin{array}{l}\text { Convention on Supplementary } \\
\text { Compensation for Nuclear Damage }\end{array}$ & & Non-Party \\
\hline RSA & $\begin{array}{l}\text { Revised Supplementary Agreement } \\
\text { Concerning the Provision of Technical } \\
\text { Assistance by the IAEA (RSA) }\end{array}$ & 1993- & Signature: 1993-01-08 \\
\hline $\mathrm{RCA}$ & $\begin{array}{l}\text { Third Agreement to Extend the } 1987 \\
\text { Regional Co-operative Agreement for }\end{array}$ & & Non-Party \\
\hline
\end{tabular}

${ }^{722}$ Office of Legal Affairs. "Saudi Arabia, Kingdom of", Country Factsheets, IAEA. Last updated 28 March 2006. Accessed 4 May 2007. http://ola.iaea.org/factSheets/CountryDetails.asp?country=SA 


\begin{tabular}{|l|l|l|l|} 
& $\begin{array}{l}\text { Research, Development and Training } \\
\text { Related to Nuclear Science and } \\
\text { Technology (RCA) }\end{array}$ & & \\
\hline AFRA & $\begin{array}{l}\text { African Regional Co-operative } \\
\text { Agreement for Research, Development } \\
\text { and Training Related to Nuclear Science } \\
\text { and Technology (AFRA) - Third } \\
\text { Extension }\end{array}$ & $\begin{array}{l}\text { Non-Party } \\
\text { Co-operation Agreement for the } \\
\text { Promotion of Nuclear Science and } \\
\text { Technology in Latin America and the } \\
\text { Caribbean (ARCAL) }\end{array}$ & Non-Party \\
\hline ARCAL & $\begin{array}{l}\text { Co-operative Agreement for Arab States } \\
\text { in Asia for Research, Development and } \\
\text { Training Related to Nuclear Science and } \\
\text { Technology (ARASIA) }\end{array}$ & 2003-06 \\
\hline ARASIA & acceptance: 2003-05-06 \\
\hline
\end{tabular}

Safeguards Agreements

No Safeguards Agreements found for this country. 
Appendix J. Algeria’s Multilateral and Safeguards Agreements. ${ }^{723}$

\begin{tabular}{|c|c|c|c|}
\hline & Title & \begin{tabular}{|c|} 
In \\
Force
\end{tabular} & Status \\
\hline P\&I & $\begin{array}{l}\text { Agreement on the Privileges and } \\
\text { Immunities of the IAEA }\end{array}$ & & Non-Party \\
\hline $\mathrm{VC}$ & $\begin{array}{l}\text { Vienna Convention on Civil Liability for } \\
\text { Nuclear Damage }\end{array}$ & & Non-Party \\
\hline $\mathrm{VC} / \mathrm{OP}$ & $\begin{array}{l}\text { Optional Protocol Concerning the } \\
\text { Compulsory Settlement of Disputes }\end{array}$ & & Non-Party \\
\hline CPPNM & $\begin{array}{l}\text { Convention on the Physical Protection of } \\
\text { Nuclear Material }\end{array}$ & $\begin{array}{l}2003- \\
05-30\end{array}$ & accession: 2003-04-30 \\
\hline CPPNME & $\begin{array}{l}\text { Amendment to the Convention on the } \\
\text { Physical Protection of Nuclear Material }\end{array}$ & & ratification: $2007-04-25$ \\
\hline NOT & $\begin{array}{l}\text { Convention on Early Notification of a } \\
\text { Nuclear Accident }\end{array}$ & $\begin{array}{l}2004- \\
02-15\end{array}$ & $\begin{array}{l}\text { Signature: } 1987-09-24 \\
\text { ratification: } 2004-01-15\end{array}$ \\
\hline ASSIST & $\begin{array}{l}\text { Convention on Assistance in the Case of a } \\
\text { Nuclear Accident or Radiological } \\
\text { Emergency }\end{array}$ & $\begin{array}{l}2004- \\
02-15\end{array}$ & $\begin{array}{l}\text { Signature: } 1987-09-24 \\
\text { ratification: } 2004-01-15\end{array}$ \\
\hline JP & $\begin{array}{l}\text { Joint Protocol Relating to the Application } \\
\text { of the Vienna Convention and the Paris } \\
\text { Convention }\end{array}$ & & Non-Party \\
\hline NS & Convention on Nuclear Safety & & Signature: 1994-09-20 \\
\hline RADW & $\begin{array}{l}\text { Joint Convention on the Safety of Spent } \\
\text { Fuel Management and on the Safety of } \\
\text { Radioactive Waste Management }\end{array}$ & & Non-Party \\
\hline PVC & $\begin{array}{l}\text { Protocol to Amend the Vienna } \\
\text { Convention on Civil Liability for Nuclear } \\
\text { Damage }\end{array}$ & & Non-Party \\
\hline SUPP & $\begin{array}{l}\text { Convention on Supplementary } \\
\text { Compensation for Nuclear Damage }\end{array}$ & & Non-Party \\
\hline RSA & $\begin{array}{l}\text { Revised Supplementary Agreement } \\
\text { Concerning the Provision of Technical } \\
\text { Assistance by the IAEA (RSA) }\end{array}$ & 1993- & Signature: 1992-10-02 \\
\hline $\mathrm{RCA}$ & Third Agreement to Extend the 1987 & & Non-Party \\
\hline
\end{tabular}

${ }^{723}$ Office of Legal Affairs. “Algeria, People's Democratic Republic of”, Country Factsheets, IAEA. Last updated 9 May 2007. Accessed 9 May 2007.

http://ola.iaea.org/factSheets/CountryDetails.asp?country=DZ 


\begin{tabular}{|l|l|l|l|} 
& $\begin{array}{l}\text { Regional Co-operative Agreement for } \\
\text { Research, Development and Training } \\
\text { Related to Nuclear Science and } \\
\text { Technology (RCA) }\end{array}$ & & \\
\hline AFRA & $\begin{array}{l}\text { African Regional Co-operative } \\
\text { Agreement for Research, Development } \\
\text { and Training Related to Nuclear Science } \\
\text { and Technology (AFRA) - Third } \\
\text { Extension }\end{array}$ & $\begin{array}{l}\text { 2005-04 } \\
\text { Ex-0 }\end{array}$ & acceptance: 2005-03-22 \\
\hline ARCAL & $\begin{array}{l}\text { Co-operation Agreement for the } \\
\text { Promotion of Nuclear Science and } \\
\text { Technology in Latin America and the } \\
\text { Caribbean (ARCAL) }\end{array}$ & Non-Party \\
\hline ARASIA & $\begin{array}{l}\text { Co-operative Agreement for Arab States } \\
\text { in Asia for Research, Development and } \\
\text { Training Related to Nuclear Science and } \\
\text { Technology (ARASIA) }\end{array}$ & Non-Party \\
\hline
\end{tabular}

\begin{tabular}{|c|c|c|c|}
\hline \multicolumn{4}{|c|}{ Safeguards Agreements } \\
\hline Reg.No & Title & $\begin{array}{c}\text { In } \\
\text { Force }\end{array}$ & Status \\
\hline 1677 & $\begin{array}{l}\text { Agreement between the People's Democratic } \\
\text { Republic of Algeria and the IAEA for the } \\
\text { Application of Safeguards in connection with } \\
\text { the NPT }\end{array}$ & $\begin{array}{l}1997- \\
01-07\end{array}$ & Signature: 1996-03-30 \\
\hline
\end{tabular}


Appendix K. Tunisia’s Multilateral and Safeguards Agreements. ${ }^{724}$

\begin{tabular}{|c|c|c|c|}
\hline & Title & $\begin{array}{c}\text { In } \\
\text { Force }\end{array}$ & Status \\
\hline P\&I & $\begin{array}{l}\text { Agreement on the Privileges and } \\
\text { Immunities of the IAEA }\end{array}$ & $\begin{array}{l}1967- \\
12-28\end{array}$ & acceptance: $1967-12-28$ \\
\hline $\mathrm{VC}$ & $\begin{array}{l}\text { Vienna Convention on Civil Liability for } \\
\text { Nuclear Damage }\end{array}$ & & Non-Party \\
\hline $\mathrm{VC} / \mathrm{OP}$ & $\begin{array}{l}\text { Optional Protocol Concerning the } \\
\text { Compulsory Settlement of Disputes }\end{array}$ & & Non-Party \\
\hline CPPNM & $\begin{array}{l}\text { Convention on the Physical Protection of } \\
\text { Nuclear Material }\end{array}$ & \begin{tabular}{|l|}
$1993-$ \\
$05-08$
\end{tabular} & accession: 1993-04-08 \\
\hline CPPNME & $\begin{array}{l}\text { Amendment to the Convention on the } \\
\text { Physical Protection of Nuclear Material }\end{array}$ & & Non-Party \\
\hline NOT & $\begin{array}{l}\text { Convention on Early Notification of a } \\
\text { Nuclear Accident }\end{array}$ & $\begin{array}{l}1989- \\
03-27\end{array}$ & $\begin{array}{l}\text { Signature: } 1987-02-24 \\
\text { ratification: } 1989-02-24\end{array}$ \\
\hline ASSIST & $\begin{array}{l}\text { Convention on Assistance in the Case of a } \\
\text { Nuclear Accident or Radiological } \\
\text { Emergency }\end{array}$ & $\begin{array}{l}1989- \\
03-27\end{array}$ & $\begin{array}{l}\text { Signature: } 1987-02-24 \\
\text { ratification: } 1989-02-24\end{array}$ \\
\hline JP & $\begin{array}{l}\text { Joint Protocol Relating to the Application } \\
\text { of the Vienna Convention and the Paris } \\
\text { Convention }\end{array}$ & & Non-Party \\
\hline NS & Convention on Nuclear Safety & & Signature: 1994-09-20 \\
\hline RADW & $\begin{array}{l}\text { Joint Convention on the Safety of Spent } \\
\text { Fuel Management and on the Safety of } \\
\text { Radioactive Waste Management }\end{array}$ & & Non-Party \\
\hline PVC & $\begin{array}{l}\text { Protocol to Amend the Vienna } \\
\text { Convention on Civil Liability for Nuclear } \\
\text { Damage }\end{array}$ & & Non-Party \\
\hline SUPP & $\begin{array}{l}\text { Convention on Supplementary } \\
\text { Compensation for Nuclear Damage }\end{array}$ & & Non-Party \\
\hline RSA & $\begin{array}{l}\text { Revised Supplementary Agreement } \\
\text { Concerning the Provision of Technical } \\
\text { Assistance by the IAEA (RSA) }\end{array}$ & $\begin{array}{l}1989- \\
02-10\end{array}$ & Signature: 1989-02-10 \\
\hline $\mathrm{RCA}$ & $\begin{array}{l}\text { Third Agreement to Extend the } 1987 \\
\text { Regional Co-operative Agreement for }\end{array}$ & & Non-Party \\
\hline
\end{tabular}

${ }^{724}$ Office of Legal Affairs. "Tunisia, Republic of”, Country Factsheets, IAEA. Last updated 9 May 2007. Accessed 14 May 2007. http://ola.iaea.org/FactSheets/CountryDetails.asp?country=TN 


\begin{tabular}{|l|l|l|l|} 
& $\begin{array}{l}\text { Research, Development and Training } \\
\text { Related to Nuclear Science and } \\
\text { Technology (RCA) }\end{array}$ & & \\
\hline AFRA & $\begin{array}{l}\text { African Regional Co-operative } \\
\text { Agreement for Research, Development } \\
\text { and Training Related to Nuclear Science } \\
\text { and Technology (AFRA) - Third } \\
\text { Extension }\end{array}$ & $\begin{array}{l}\text { 2005- } \\
\text { 05-04 }\end{array}$ & acceptance: 2005-05-04 \\
\hline ARCAL & $\begin{array}{l}\text { Co-operation Agreement for the } \\
\text { Promotion of Nuclear Science and } \\
\text { Technology in Latin America and the } \\
\text { Caribbean (ARCAL) }\end{array}$ & Non-Party \\
\hline ARASIA & $\begin{array}{l}\text { Co-operative Agreement for Arab States } \\
\text { in Asia for Research, Development and } \\
\text { Training Related to Nuclear Science and } \\
\text { Technology (ARASIA) }\end{array}$ & Non-Party \\
\hline
\end{tabular}

Safeguards Agreements

\begin{tabular}{|l|l|c|c|}
\hline Reg.No & \multicolumn{1}{|c|}{ Title } & $\begin{array}{c}\text { In } \\
\text { Force }\end{array}$ & \multicolumn{1}{|c|}{ Status } \\
\hline 1587 & $\begin{array}{l}\text { Agreement between the Republic of Tunisia } \\
\text { and the IAEA for the application of } \\
\text { safeguards in connection with the Treaty on } \\
\text { the Non-Prolifertion of Nuclear Weapons }\end{array}$ & $\begin{array}{l}1990- \\
03-13\end{array}$ & Signature: 1989-02-24 \\
\hline
\end{tabular}




\section{Appendix L. The United Arab Emirates' Multilateral and Safeguards Agreements. $^{725}$}

\begin{tabular}{|c|c|c|c|}
\hline & Title & \begin{tabular}{|c|} 
In \\
Force
\end{tabular} & Status \\
\hline P\&I & $\begin{array}{l}\text { Agreement on the Privileges and } \\
\text { Immunities of the IAEA }\end{array}$ & & Non-Party \\
\hline VC & $\begin{array}{l}\text { Vienna Convention on Civil Liability for } \\
\text { Nuclear Damage }\end{array}$ & & Non-Party \\
\hline $\mathrm{VC} / \mathrm{OP}$ & $\begin{array}{l}\text { Optional Protocol Concerning the } \\
\text { Compulsory Settlement of Disputes }\end{array}$ & & Non-Party \\
\hline CPPNM & $\begin{array}{l}\text { Convention on the Physical Protection of } \\
\text { Nuclear Material }\end{array}$ & $\begin{array}{l}2003- \\
11-15\end{array}$ & accession: $2003-10-16$ \\
\hline CPPNME & $\begin{array}{l}\text { Amendment to the Convention on the } \\
\text { Physical Protection of Nuclear Material }\end{array}$ & & Non-Party \\
\hline NOT & $\begin{array}{l}\text { Convention on Early Notification of a } \\
\text { Nuclear Accident }\end{array}$ & \begin{tabular}{|l|}
$1987-$ \\
$11-02$
\end{tabular} & accession: $1987-10-02$ \\
\hline ASSIST & $\begin{array}{l}\text { Convention on Assistance in the Case of a } \\
\text { Nuclear Accident or Radiological } \\
\text { Emergency }\end{array}$ & $\begin{array}{l}1987- \\
11-02\end{array}$ & accession: $1987-10-02$ \\
\hline JP & $\begin{array}{l}\text { Joint Protocol Relating to the Application } \\
\text { of the Vienna Convention and the Paris } \\
\text { Convention }\end{array}$ & & Non-Party \\
\hline NS & Convention on Nuclear Safety & & Non-Party \\
\hline RADW & $\begin{array}{l}\text { Joint Convention on the Safety of Spent } \\
\text { Fuel Management and on the Safety of } \\
\text { Radioactive Waste Management }\end{array}$ & & Non-Party \\
\hline PVC & $\begin{array}{l}\text { Protocol to Amend the Vienna } \\
\text { Convention on Civil Liability for Nuclear } \\
\text { Damage }\end{array}$ & & Non-Party \\
\hline SUPP & $\begin{array}{l}\text { Convention on Supplementary } \\
\text { Compensation for Nuclear Damage }\end{array}$ & & Non-Party \\
\hline RSA & $\begin{array}{l}\text { Revised Supplementary Agreement } \\
\text { Concerning the Provision of Technical } \\
\text { Assistance by the IAEA (RSA) }\end{array}$ & $\begin{array}{l}1989- \\
02-04\end{array}$ & Signature: 1989-02-04 \\
\hline RCA & Third Agreement to Extend the 1987 & & Non-Party \\
\hline
\end{tabular}

${ }^{725}$ Office of Legal Affairs. "United Arab Emirates", Country Factsheets, IAEA. Last updated 9 May 2007. Accessed 24 May 2007. http://ola.iaea.org/factSheets/CountryDetails.asp?country=AE 


\begin{tabular}{|l|l|l|l|} 
& $\begin{array}{l}\text { Regional Co-operative Agreement for } \\
\text { Research, Development and Training } \\
\text { Related to Nuclear Science and } \\
\text { Technology (RCA) }\end{array}$ & & \\
\hline AFRA & $\begin{array}{l}\text { African Regional Co-operative } \\
\text { Agreement for Research, Development } \\
\text { and Training Related to Nuclear Science } \\
\text { and Technology (AFRA) - Third } \\
\text { Extension }\end{array}$ & $\begin{array}{l}\text { Non-Party } \\
\text { Co-operation Agreement for the } \\
\text { Promotion of Nuclear Science and } \\
\text { Technology in Latin America and the } \\
\text { Caribbean (ARCAL) }\end{array}$ & Non-Party \\
\hline ARCAL & $\begin{array}{l}\text { Co-operative Agreement for Arab States } \\
\text { in Asia for Research, Development and } \\
\text { Training Related to Nuclear Science and } \\
\text { Technology (ARASIA) }\end{array}$ & $\begin{array}{l}\text { 2002- } \\
\text { 09-02 }\end{array}$ & acceptance: 2002-09-02 \\
\hline ARASIA & & \\
\hline
\end{tabular}

\begin{tabular}{|c|c|c|c|}
\hline \multicolumn{4}{|c|}{ Safeguards Agreements } \\
\hline Reg.No & Title & $\begin{array}{c}\text { In } \\
\text { Force }\end{array}$ & Status \\
\hline 1760 & $\begin{array}{l}\text { Agreement between the United Arab } \\
\text { Emirates and the International Atomic } \\
\text { Energy Agency for the Application of } \\
\text { Safeguards in Connection with the Treaty on } \\
\text { the Non-Proliferation of Nuclear Weapons }\end{array}$ & $\begin{array}{l}2003- \\
10-09\end{array}$ & Signature: 2002-12-15 \\
\hline
\end{tabular}


Appendix M. Kuwait’s Multilateral and Safeguards Agreements. ${ }^{726}$

\begin{tabular}{|c|c|c|c|}
\hline & Title & $\begin{array}{c}\text { In } \\
\text { Force }\end{array}$ & Status \\
\hline P\&I & $\begin{array}{l}\text { Agreement on the Privileges and } \\
\text { Immunities of the IAEA }\end{array}$ & $\begin{array}{l}1998- \\
09-15\end{array}$ & acceptance: $1998-09-15$ \\
\hline $\mathrm{VC}$ & $\begin{array}{l}\text { Vienna Convention on Civil Liability for } \\
\text { Nuclear Damage }\end{array}$ & & Non-Party \\
\hline $\mathrm{VC} / \mathrm{OP}$ & $\begin{array}{l}\text { Optional Protocol Concerning the } \\
\text { Compulsory Settlement of Disputes }\end{array}$ & & Non-Party \\
\hline CPPNM & $\begin{array}{l}\text { Convention on the Physical Protection of } \\
\text { Nuclear Material }\end{array}$ & $\begin{array}{l}2004- \\
05-23\end{array}$ & accession: 2004-04-23 \\
\hline CPPNME & $\begin{array}{l}\text { Amendment to the Convention on the } \\
\text { Physical Protection of Nuclear Material }\end{array}$ & & Non-Party \\
\hline NOT & $\begin{array}{l}\text { Convention on Early Notification of a } \\
\text { Nuclear Accident }\end{array}$ & $\begin{array}{l}2003- \\
06-13\end{array}$ & accession: 2003-05-13 \\
\hline ASSIST & $\begin{array}{l}\text { Convention on Assistance in the Case of a } \\
\text { Nuclear Accident or Radiological } \\
\text { Emergency }\end{array}$ & $\begin{array}{l}2003- \\
06-13\end{array}$ & accession: $2003-05-13$ \\
\hline JP & $\begin{array}{l}\text { Joint Protocol Relating to the Application } \\
\text { of the Vienna Convention and the Paris } \\
\text { Convention }\end{array}$ & & Non-Party \\
\hline NS & Convention on Nuclear Safety & 2006- & accession: 2006-05-11 \\
\hline RADW & $\begin{array}{l}\text { Joint Convention on the Safety of Spent } \\
\text { Fuel Management and on the Safety of } \\
\text { Radioactive Waste Management }\end{array}$ & & Non-Party \\
\hline PVC & $\begin{array}{l}\text { Protocol to Amend the Vienna } \\
\text { Convention on Civil Liability for Nuclear } \\
\text { Damage }\end{array}$ & & Non-Party \\
\hline SUPP & $\begin{array}{l}\text { Convention on Supplementary } \\
\text { Compensation for Nuclear Damage }\end{array}$ & & Non-Party \\
\hline RSA & $\begin{array}{l}\text { Revised Supplementary Agreement } \\
\text { Concerning the Provision of Technical } \\
\text { Assistance by the IAEA (RSA) }\end{array}$ & $\begin{array}{l}2003- \\
02-24\end{array}$ & Signature: 2003-02-24 \\
\hline $\mathrm{RCA}$ & Third Agreement to Extend the 1987 & & Non-Party \\
\hline
\end{tabular}

\footnotetext{
${ }^{726}$ Office of Legal Affairs. "Kuwait”, Country Factsheets, IAEA. Last updated 9 May 2007. Accessed 5 June 2007. http://ola.iaea.org/factSheets/CountryDetails.asp?country=KW
} 


\begin{tabular}{|l|l|l|l|} 
& $\begin{array}{l}\text { Regional Co-operative Agreement for } \\
\text { Research, Development and Training } \\
\text { Related to Nuclear Science and } \\
\text { Technology (RCA) }\end{array}$ & & \\
\hline AFRA & $\begin{array}{l}\text { African Regional Co-operative } \\
\text { Agreement for Research, Development } \\
\text { and Training Related to Nuclear Science } \\
\text { and Technology (AFRA) - Third } \\
\text { Extension }\end{array}$ & Non-Party \\
\hline ARASIA & $\begin{array}{l}\text { Co-operative Agreement for Arab States } \\
\text { in Asia for Research, Development and } \\
\text { Training Related to Nuclear Science and } \\
\text { Technology (ARASIA) }\end{array}$ & Non-Party \\
\hline
\end{tabular}

Safeguards Agreements

\begin{tabular}{|l|l|l|l|}
\hline Reg.No & \multicolumn{1}{|c|}{ Title } & $\begin{array}{c}\text { In } \\
\text { Force }\end{array}$ & \multicolumn{1}{|c|}{ Status } \\
\hline 1735 & $\begin{array}{l}\text { Agreement between the State of Kuwait and } \\
\text { the International Atomic Energy Agency for } \\
\text { the Application of Safeguards in Connection } \\
\text { with the Treaty on the Non- Proliferation of } \\
\text { Nuclear Weapons }\end{array}$ & $\begin{array}{l}\text { 2002- } \\
\text { 03-07 }\end{array}$ & Signature: 1999-05-10 \\
\hline 1753 & $\begin{array}{l}\text { Protocol Additional to the Agreement } \\
\text { between the State of Kuwait and the } \\
\text { International Atomic Energy Agency for the } \\
\text { Application of Safeguards in Connection with } \\
\text { the Treaty on the Non-Proliferation of } \\
\text { Nuclear Weapons }\end{array}$ & 2003-02 & Signature: 2002-06-19 \\
\hline
\end{tabular}


Appendix N. Oman’s Multilateral and Safeguards Agreements. ${ }^{727}$

\begin{tabular}{|c|c|c|c|}
\hline & Title & $\begin{array}{c}\text { In } \\
\text { Force }\end{array}$ & Status \\
\hline P\&I & $\begin{array}{l}\text { Agreement on the Privileges and } \\
\text { Immunities of the IAEA }\end{array}$ & & Non-Party \\
\hline $\mathrm{VC}$ & $\begin{array}{l}\text { Vienna Convention on Civil Liability for } \\
\text { Nuclear Damage }\end{array}$ & & Non-Party \\
\hline $\mathrm{VC} / \mathrm{OP}$ & $\begin{array}{l}\text { Optional Protocol Concerning the } \\
\text { Compulsory Settlement of Disputes }\end{array}$ & & Non-Party \\
\hline CPPNM & $\begin{array}{l}\text { Convention on the Physical Protection of } \\
\text { Nuclear Material }\end{array}$ & $\begin{array}{l}2003- \\
07-11\end{array}$ & accession: 2003-06-11 \\
\hline CPPNME & $\begin{array}{l}\text { Amendment to the Convention on the } \\
\text { Physical Protection of Nuclear Material }\end{array}$ & & Non-Party \\
\hline NOT & $\begin{array}{l}\text { Convention on Early Notification of a } \\
\text { Nuclear Accident }\end{array}$ & & Non-Party \\
\hline ASSIST & $\begin{array}{l}\text { Convention on Assistance in the Case of a } \\
\text { Nuclear Accident or Radiological } \\
\text { Emergency }\end{array}$ & & Non-Party \\
\hline JP & $\begin{array}{l}\text { Joint Protocol Relating to the Application } \\
\text { of the Vienna Convention and the Paris } \\
\text { Convention }\end{array}$ & & Non-Party \\
\hline NS & Convention on Nuclear Safety & & Non-Party \\
\hline RADW & $\begin{array}{l}\text { Joint Convention on the Safety of Spent } \\
\text { Fuel Management and on the Safety of } \\
\text { Radioactive Waste Management }\end{array}$ & & Non-Party \\
\hline PVC & $\begin{array}{l}\text { Protocol to Amend the Vienna Convention } \\
\text { on Civil Liability for Nuclear Damage }\end{array}$ & & Non-Party \\
\hline SUPP & $\begin{array}{l}\text { Convention on Supplementary } \\
\text { Compensation for Nuclear Damage }\end{array}$ & & Non-Party \\
\hline RSA & $\begin{array}{l}\text { Revised Supplementary Agreement } \\
\text { Concerning the Provision of Technical } \\
\text { Assistance by the IAEA (RSA) }\end{array}$ & & Non-Party \\
\hline $\mathrm{RCA}$ & $\begin{array}{l}\text { Third Agreement to Extend the } 1987 \\
\text { Regional Co-operative Agreement for } \\
\text { Research, Development and Training }\end{array}$ & & Non-Party \\
\hline
\end{tabular}

${ }^{727}$ Office of Legal Affairs. “Oman, Sultanate of", Country Factsheets, IAEA. Last updated 9 May 2007. Accessed 6 June 2007. http://ola.iaea.org/factSheets/CountryDetails.asp?country=OM 


\begin{tabular}{|l|l|l|l|} 
& $\begin{array}{l}\text { Related to Nuclear Science and } \\
\text { Technology (RCA) }\end{array}$ & & \\
\hline AFRA & $\begin{array}{l}\text { African Regional Co-operative Agreement } \\
\text { for Research, Development and Training } \\
\text { Related to Nuclear Science and } \\
\text { Technology (AFRA) - Third Extension }\end{array}$ & Non-Party \\
\hline ARCAL & $\begin{array}{l}\text { Co-operation Agreement for the Promotion } \\
\text { of Nuclear Science and Technology in } \\
\text { Latin America and the Caribbean } \\
\text { (ARCAL) }\end{array}$ & $\begin{array}{l}\text { Non-Party } \\
\text { ARASIA }\end{array}$ & $\begin{array}{l}\text { Co-operative Agreement for Arab States in } \\
\text { Asia for Research, Development and } \\
\text { Training Related to Nuclear Science and } \\
\text { Technology (ARASIA) }\end{array}$ \\
\hline
\end{tabular}

Safeguards Agreements

\begin{tabular}{|l|l|l|l|}
\hline Reg.No & \multicolumn{1}{|c|}{ Title } & $\begin{array}{c}\text { In } \\
\text { Force }\end{array}$ & \multicolumn{1}{|c|}{ Status } \\
\hline 1809 & $\begin{array}{l}\text { Agreement between the Sultanate of Oman } \\
\text { and the International Atomic Energy Agency } \\
\text { for the Application of Safeguards in } \\
\text { connection with the Treaty on the Non- } \\
\text { Proliferation of Nuclear Weapons }\end{array}$ & $\begin{array}{l}\text { 2006- } \\
\text { 09-05 }\end{array}$ & Signature: 2001-06-28 \\
\hline
\end{tabular}


Appendix O. Qatar's Multilateral and Safeguards Agreements. ${ }^{728}$

\begin{tabular}{|c|c|c|c|}
\hline & Title & $\begin{array}{c}\text { In } \\
\text { Force }\end{array}$ & Status \\
\hline P\&I & $\begin{array}{l}\text { Agreement on the Privileges and } \\
\text { Immunities of the IAEA }\end{array}$ & & Non-Party \\
\hline $\mathrm{VC}$ & $\begin{array}{l}\text { Vienna Convention on Civil Liability for } \\
\text { Nuclear Damage }\end{array}$ & & Non-Party \\
\hline $\mathrm{VC} / \mathrm{OP}$ & $\begin{array}{l}\text { Optional Protocol Concerning the } \\
\text { Compulsory Settlement of Disputes }\end{array}$ & & Non-Party \\
\hline CPPNM & $\begin{array}{l}\text { Convention on the Physical Protection of } \\
\text { Nuclear Material }\end{array}$ & $\begin{array}{l}2004- \\
04-08\end{array}$ & accession: 2004-03-09 \\
\hline CPPNME & $\begin{array}{l}\text { Amendment to the Convention on the } \\
\text { Physical Protection of Nuclear Material }\end{array}$ & & Non-Party \\
\hline NOT & $\begin{array}{l}\text { Convention on Early Notification of a } \\
\text { Nuclear Accident }\end{array}$ & $\begin{array}{l}2005- \\
12-04\end{array}$ & accession: 2005-11-04 \\
\hline ASSIST & $\begin{array}{l}\text { Convention on Assistance in the Case of a } \\
\text { Nuclear Accident or Radiological } \\
\text { Emergency }\end{array}$ & $\begin{array}{l}2005- \\
12-04\end{array}$ & accession: 2005-11-04 \\
\hline JP & $\begin{array}{l}\text { Joint Protocol Relating to the Application } \\
\text { of the Vienna Convention and the Paris } \\
\text { Convention }\end{array}$ & & Non-Party \\
\hline NS & Convention on Nuclear Safety & & Non-Party \\
\hline RADW & $\begin{array}{l}\text { Joint Convention on the Safety of Spent } \\
\text { Fuel Management and on the Safety of } \\
\text { Radioactive Waste Management }\end{array}$ & & Non-Party \\
\hline PVC & $\begin{array}{l}\text { Protocol to Amend the Vienna Convention } \\
\text { on Civil Liability for Nuclear Damage }\end{array}$ & & Non-Party \\
\hline SUPP & $\begin{array}{l}\text { Convention on Supplementary } \\
\text { Compensation for Nuclear Damage }\end{array}$ & & Non-Party \\
\hline RSA & $\begin{array}{l}\text { Revised Supplementary Agreement } \\
\text { Concerning the Provision of Technical } \\
\text { Assistance by the IAEA (RSA) }\end{array}$ & $\begin{array}{l}1991- \\
05-29\end{array}$ & Signature: 1991-05-29 \\
\hline $\mathrm{RCA}$ & $\begin{array}{l}\text { Third Agreement to Extend the } 1987 \\
\text { Regional Co-operative Agreement for } \\
\text { Research, Development and Training }\end{array}$ & & Non-Party \\
\hline
\end{tabular}

${ }^{728}$ Office of Legal Affairs. “Qatar, State of”, Country Factsheets, IAEA. Last updated 9 May 2007. Accessed 8 June 2007. http://ola.iaea.org/factSheets/CountryDetails.asp?country=QA 


\begin{tabular}{|l|l|l|l|} 
& $\begin{array}{l}\text { Related to Nuclear Science and } \\
\text { Technology (RCA) }\end{array}$ & & \\
\hline AFRA & $\begin{array}{l}\text { African Regional Co-operative Agreement } \\
\text { for Research, Development and Training } \\
\text { Related to Nuclear Science and } \\
\text { Technology (AFRA) - Third Extension }\end{array}$ & Non-Party \\
\hline ARCAL & $\begin{array}{l}\text { Co-operation Agreement for the Promotion } \\
\text { of Nuclear Science and Technology in } \\
\text { Latin America and the Caribbean } \\
\text { (ARCAL) }\end{array}$ & Non-Party \\
\hline ARASIA & $\begin{array}{l}\text { Co-operative Agreement for Arab States in } \\
\text { Asia for Research, Development and } \\
\text { Training Related to Nuclear Science and } \\
\text { Technology (ARASIA) }\end{array}$ & Non-Party \\
\hline
\end{tabular}

Safeguards Agreements

No Safeguards Agreements have been established for this country. 
Appendix P. Yemen’s Multilateral and Safeguards Agreements. ${ }^{729}$

\begin{tabular}{|c|c|c|c|}
\hline & Title & \begin{tabular}{|c|} 
In \\
Force
\end{tabular} & Status \\
\hline P\&I & $\begin{array}{l}\text { Agreement on the Privileges and } \\
\text { Immunities of the IAEA }\end{array}$ & & Non-Party \\
\hline $\mathrm{VC}$ & $\begin{array}{l}\text { Vienna Convention on Civil Liability for } \\
\text { Nuclear Damage }\end{array}$ & & Non-Party \\
\hline $\mathrm{VC} / \mathrm{OP}$ & $\begin{array}{l}\text { Optional Protocol Concerning the } \\
\text { Compulsory Settlement of Disputes }\end{array}$ & & Non-Party \\
\hline CPPNM & $\begin{array}{l}\text { Convention on the Physical Protection of } \\
\text { Nuclear Material }\end{array}$ & & Non-Party \\
\hline CPPNME & $\begin{array}{l}\text { Amendment to the Convention on the } \\
\text { Physical Protection of Nuclear Material }\end{array}$ & & Non-Party \\
\hline NOT & $\begin{array}{l}\text { Convention on Early Notification of a } \\
\text { Nuclear Accident }\end{array}$ & & Non-Party \\
\hline ASSIST & $\begin{array}{l}\text { Convention on Assistance in the Case of a } \\
\text { Nuclear Accident or Radiological } \\
\text { Emergency }\end{array}$ & & Non-Party \\
\hline $\mathrm{JP}$ & $\begin{array}{l}\text { Joint Protocol Relating to the Application } \\
\text { of the Vienna Convention and the Paris } \\
\text { Convention }\end{array}$ & & Non-Party \\
\hline NS & Convention on Nuclear Safety & & Non-Party \\
\hline RADW & $\begin{array}{l}\text { Joint Convention on the Safety of Spent } \\
\text { Fuel Management and on the Safety of } \\
\text { Radioactive Waste Management }\end{array}$ & & Non-Party \\
\hline PVC & $\begin{array}{l}\text { Protocol to Amend the Vienna } \\
\text { Convention on Civil Liability for Nuclear } \\
\text { Damage }\end{array}$ & & Non-Party \\
\hline SUPP & $\begin{array}{l}\text { Convention on Supplementary } \\
\text { Compensation for Nuclear Damage }\end{array}$ & & Non-Party \\
\hline RSA & $\begin{array}{l}\text { Revised Supplementary Agreement } \\
\text { Concerning the Provision of Technical } \\
\text { Assistance by the IAEA (RSA) }\end{array}$ & & Non-Party \\
\hline RCA & $\begin{array}{l}\text { Third Agreement to Extend the } 1987 \\
\text { Regional Co-operative Agreement for } \\
\text { Research, Development and Training }\end{array}$ & & Non-Party \\
\hline
\end{tabular}

${ }^{729}$ Office of Legal Affairs. "Qatar, State of”, Country Factsheets, IAEA. Last updated 9 May 2007. Accessed 8 June 2007. http://ola.iaea.org/factSheets/CountryDetails.asp?country=QA 


\begin{tabular}{|c|c|c|c|}
\hline & $\begin{array}{l}\text { Related to Nuclear Science and } \\
\text { Technology (RCA) }\end{array}$ & & \\
\hline AFRA & $\begin{array}{l}\text { African Regional Co-operative } \\
\text { Agreement for Research, Development } \\
\text { and Training Related to Nuclear Science } \\
\text { and Technology (AFRA) - Third } \\
\text { Extension }\end{array}$ & & Non-Party \\
\hline ARCAL & $\begin{array}{l}\text { Co-operation Agreement for the } \\
\text { Promotion of Nuclear Science and } \\
\text { Technology in Latin America and the } \\
\text { Caribbean (ARCAL) }\end{array}$ & & Non-Party \\
\hline ARASIA & $\begin{array}{l}\text { Co-operative Agreement for Arab States } \\
\text { in Asia for Research, Development and } \\
\text { Training Related to Nuclear Science and } \\
\text { Technology (ARASIA) }\end{array}$ & $\begin{array}{l}2002- \\
07-29\end{array}$ & acceptance: 2002-07-08 \\
\hline
\end{tabular}

Safeguards Agreements

\begin{tabular}{|l|l|l|l|}
\hline Reg.No & \multicolumn{1}{|c|}{ Title } & $\begin{array}{c}\text { In } \\
\text { Force }\end{array}$ & \multicolumn{1}{|c|}{ Status } \\
\hline 1741 & $\begin{array}{l}\text { Agreement between the Republic of Yemen } \\
\text { and the International Atomic Energy Agency } \\
\text { for the Application of Safeguards in } \\
\text { Connection with the Treaty on the Non- } \\
\text { Proliferation of Nuclear Weapons }\end{array}$ & $\begin{array}{l}\text { 2002- } \\
\text { 08-14 }\end{array}$ & Signature: 2000-09-21 \\
\hline
\end{tabular}




\section{Appendix Q. Nuclear Desalination}

Desalination is an energy-intensive process, requiring about $6 \mathrm{kWh} / \mathrm{m}^{3}$ of electricity for a reverse osmosis process driven by electric pumps, or heat at $70-130^{\circ} \mathrm{C}$ and $25-200$ $\mathrm{kWh} / \mathrm{m}^{3}$ of electricity for the multi-stage flash (MSF) distillation process using steam or the multi-effect distillation (MED) process. Nuclear desalination is more environmentally friendly than fossil fuel-powered desalination and can be more cost effective. Small and medium sized nuclear reactors are suitable for desalination, often with cogeneration of electricity using low-pressure steam from the turbine and hot sea water feed from the final cooling system. Water can be desalinated in quantities in the range of $80-100,000 \mathrm{~m}^{3} /$ day for small reactors and $200-500,000 \mathrm{~m}^{3} /$ day for medium reactors $^{730}$.

${ }^{730}$ Uranium Information Centre, Ltd. “Nuclear Desalination,” UIC Nuclear Issues Briefing Paper \# 74. October 2006. Accessed 5 April 2007. http://www.uic.com.au/nip74.htm 


\section{Appendix R. The Definition of Types of Hydrocarbon and Uranium Reserves}

According to the Organization of Economic Cooperation and Development (OECD), the following are applicable definitions of various forms of conventional reserves. These definitions are the working terms for the entirety of these reports ${ }^{731}$.

\section{Proven Reserves:}

Proven reserves are such estimated quantities of mineral deposits, at a specific date, as analysis of geologic engineering data demonstrates with reasonable certainty to be recoverable in the future under the same economic and operational conditions.

\section{Probable Reserves:}

Reserves which are known to exist but where some doubt exists over whether they are technically or economically viable.

\section{Possible Reserves:}

Reserves where there is considerable doubt over the technical and or financial viability of extraction.

\section{Unconventional Reserves:}

For the purpose of this report, unconventional reserves will reference mineral resources that provide for either uranium or petroleum from secondary sources. For uranium this includes advanced processing of phosphates in order to attain uranium. For petroleum, unconventional reserves include oil shale, tar sands, and in some cases the products of future enhanced oil recovery with injected gasses.

\footnotetext{
${ }^{731}$ OECD Glossary of Statistical Terms Accessed 7 August 2007. http://stats.oecd.org/glossary/detail.asp?ID=2187
} 


\section{PNWCGS Mission}

Our mission is to address the full range of global security issues by probing the impact of economic, social, institutional and environmental conditions that affect regional stability and global security. We emphasize non-proliferation due to its consequence for global security.

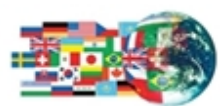

Pacific Northwest Center for

Global Security

For more information, contact:

Carol Kessler, Director

Pacific Northwest Center for Global Security

Pacific Northwest National Laboratory

1100 Dexter Avenue North, Suite 400

Seattle, WA 98109

Phone: 206-528-3222

Fax: 206-528-3225 